UNIVERSIDADE DE SÃO PAULO

FACULDADE DE EDUCAÇÃO

MARILENE DE MELO VIEIRA

\title{
Filosofia da educação na formação do pedagogo: discurso de autonomia e fabricação da heteronomia
}


MARILENE DE MELO VIEIRA

Filosofia da educação na formação do pedagogo:

discurso de autonomia e fabricação da heteronomia

Tese apresentada à Faculdade de Educação da Universidade de São Paulo, para obtenção do título de Doutor em Educação.

Área de concentração: Filosofia e Educação

Orientador: Prof. Dr. Antônio Joaquim Severino

São Paulo 
Autorizo a reprodução e divulgação total ou parcial deste trabalho, por qualquer meio convencional ou eletrônico, para fins de estudo e pesquisa, desde que citada a fonte.

Catalogação na Publicação

Serviço de Biblioteca e Documentação

Faculdade de Educação da Universidade de São Paulo

$37.01 \quad$ Vieira, Marilene de Melo

V658f Filosofia da educação na formação do pedagogo : discurso de autonomia e fabricação da heteronomia / Marilene de Melo Vieira ; orientação Antônio Joaquim Severino. São Paulo : s.n., 2010.

$216 \mathrm{p}$.

Tese (Doutorado - Programa de Pós-Graduação em Educação. Área de Concentração : Filosofia e Educação) - - Faculdade de Educação da Universidade de São Paulo.

1. Filosofia e Educação 2. Formação de professores 3. Cidadania 4. Democracia 4. Interrogação I. Severino, Antônio Joaquim, orient. 
VIEIRA, M. de M. Filosofia da Educacão na formação do pedagogo: discurso de autonomia e fabricação da heteronomia. Tese apresentada à Faculdade de Educação da Universidade de São Paulo para obtenção do título de Doutor em Educação.

Aprovado em:

Banca Examinadora

Prof. ${ }^{\text {a }}$ Dr. $^{\mathrm{a}}$ Instituição:

Julgamento:

Assinatura:

Prof. ${ }^{\mathrm{a}}$ Dr. ${ }^{\mathrm{a}}$

Instituição:

Julgamento:

Assinatura:

Prof. Dr.

Instituição:

Julgamento:

Assinatura:

Prof. Dr.

Instituição:

Julgamento:

Assinatura:

Prof. Dr.

Instituição:

Julgamento:

Assinatura: 
A Yuri Cysne Vieira, pela oportunidade de reencontrar-me e de exercer a minha afetividade.

A Valéria, pela difícil, mas frutífera, convivência com a alteridade e com a diferença.

Às minhas irmãs, Ceni e Leonina, pela postura de vida comprometida com a família e com a educação.

A Maria Célia e família, pelo convívio e apoio quando do meu tempo em Sampa.

À memória de Sebastião J. Vieira, Maria de M. Vieira, Mariana de Melo, Maria Helena Vieira, José Célio Vieira e Íris Bastos Cysne, presenças constantes em minha vida.

A todos que pensam que educação e política são as chaves para a instituição de uma sociedade democrática, justa e feliz. 


\section{AGRADECIMENTOS}

A criação é tempo de estar consigo, do aflorar da imaginação, é tempo de trabalho solitário, de amadurecimento intelectual e pessoal.

Embora trabalho solitário, este momento do doutoramento não se efetiva no total isolamento ou clausura, mas é sempre tributário de relações sociais, pois sempre há pessoas próximas ou não, fisicamente ou pelas ideias, que nos alentam, atormentam, estimulam, criticam e apoiam.

A essas pessoas, agradeço por terem partilhado e participado de minha formação como pessoa e como docente.

Agradeço à Universidade Federal de Viçosa/Departamento de Educação e à PróReitoria de Pesquisa e Pós-Graduação, na pessoa dos funcionários, pelo apoio e a pela viabilização da concretização do curso mediante a liberação de meu tempo de trabalho.

À CAPES pela bolsa de estudos.

Aos coordenadores e funcionários do Programa de Pós-Graduação em Educação da Faculdade de Educação da USP.

À professora Therezinha Mucci, pelo apoio e pela revisão do texto.

Em especial, ao meu orientador, professor Antônio Joaquim Severino, pelas sugestões, pelas críticas e pelo apoio.

À professora Lílian Aragão Bastos do Valle, pela convivência, pela participação e pelo compartilhamento da produção de Cornelius Castoriadis. 
Tenho o desejo e sinto necessidade, para viver, de uma outra sociedade diferente dessa que me rodeia. Como a grande maioria dos homens, posso viver nesta aqui e acomodarme - de qualquer forma, vivo nela. Por mais criticamente que tente olhar-me, nem minha capacidade de adaptação, nem minha assimilação da realidade me parecem inferiores ao meio sociológico. Não peço a imortalidade, a ubiqüidade, a onisciência. Não peço que a sociedade "me dê a felicidade"; sei que isso não é uma ração que poderia ser distribuída pela municipalidade ou pelo Conselho operário do bairro, e que, se esta coisa existe, somente eu posso construí-la para mim, nas minhas medidas, como já me aconteceu e como ainda me acontecerá, sem dúvida. Mas na vida, como ela é feita para mim e para os outros, entrechoco-me com uma quantidade de coisas inadmissíveis, digo que elas não são fatais e que decorrem da organização da sociedade. Desejo e peço que antes de tudo meu trabalho tenha um sentido, que eu possa aprovar aquilo a que lhe serve a maneira como é feito e que me permita entregar-me a ele verdadeiramente e usar minhas faculdades, bem como enriquecer-me e desenvolver-me. E digo que isso é possível, com uma outra organização da sociedade, para mim e para todos. Digo que já seria uma mudança fundamental nesse sentido, se me deixassem decidir, com todos os outros, o que tenho a fazer, e, com meus companheiros de trabalho, como fazê-lo.

Desejo poder, com todos os outros, saber o que se passa na sociedade, controlar a extensão e a qualidade da informação que me é dada. Peço para poder participar diretamente de todas as decisões sociais que possam afetar minha existência ou o curso geral do mundo em que vivo. Não aceito que meu destino seja decidido, dia após dia, por pessoas cujos projetos me são hostis ou simplesmente desconhecidos e para quem não passamos eu e todos os outros, de números num plano ou peões sobre um tabuleiro de xadrez e que em última análise, minha vida e morte estejam nas mãos de pessoas que sei serem necessariamente cegas. 
Castoriadis

Educar uma criança (quer como pai ou como pedagogo) pode ser feito com uma consciência e uma lucidez mais ou menos grandes, mas é por definição impossível que 
isso possa ser feito a partir de uma elucidação total do ser da criança e da relação pedagógica.

\section{RESUMO}

VIEIRA, M. de M. Filosofia da Educacão na formação do pedagogo: discurso de autonomia e fabricação da heteronomia. 2010. $221 \mathrm{f}$. Tese (Doutorado) - Faculdade de Educacão, Universidade de São Paulo, São Paulo, 2010.

.Esta tese teve por objetivos analisar a possibilidade de a disciplina Filosofia da Educação contribuir para que os educandos construam sua autonomia e propor diretrizes para seu projeto. Teoricamente, a investigação apoia-se no processo de autocriação da sociedade e da fabricação de seus indivíduos, nas dimensões imaginárias e conjuntistaidentitária. Para melhor compreensão da disciplina, buscaram-se a sua instituição na formação dos educadores, com análise do monopólio legislativo do Estado na educação; a institucionalização da formação dos professores e a tentativa de cientismo da educação. Elegeram-se como material empírico da proposta, as disciplinas de Filosofia da Educação do curso de Pedagogia da Universidade Federal de Viçosa, que guardavam, em geral, identificação/semelhança com seus congêneres em outras instituições, bem como entrevistas com dirigentes acadêmicos e professores que as ministravam. Em virtude de a organização, estrutura e conteúdo dessas disciplinas não potencializarem a interrogação e nem a possibilidade de construção de sua autonomia pelos educandos, consistindo tão-somente em discurso de autonomia e fabricação da heteronomia, este trabalho fundamentou-se no pensamento de que a única Filosofia da Educação que pode contribuir para a construção do sujeito reflexivo e deliberante, e do espaço democrático, é a que se interroga incessantemente. Propuseram-se, então, para tal disciplina, entre outras, as diretrizes referentes à instalação de uma crise das verdades e das certezas dos educadores, dos educandos e a aspiração de autonomia/cidadania/democracia.

Palavras-chave: Filosofia da Educação, autonomia e interrogação sem limites. 


\begin{abstract}
VIEIRA, M. de M. Philosophy of Education: discourse of autonomy and fabrication of heteronomy. (2010) Doctoral dissertation, 221pp. São Paulo; Faculty of Education, University of São Paulo.
\end{abstract}

This thesis aims to analyze if the Philosophy of Education course can help students build their autonomy proposing guidelines for their projects. Theoretically, the investigation is based on the society's process of self-creation and fabrication of its individuals, in imaginary and conjunctionist-identitary dimensions. For further comprehension of the course, its institution was sought in the education of the teachers, analyzing the State Law monopoly in education. The empiric material chosen for this proposal were the Philosophy of Education courses for the Major in Education at the Federal University of Viçosa (Minas Gerais, Brazil), keeping, in general, identity/similarity with its similar courses in other institutions, as well as interviews with the academic directors and professors who teach it. Since the organization, structure and syllabus of these courses do not leverage questioning nor enable students to build their autonomy, consisting merely of the discourse of autonomy and fabrication of heteronomy, this research was based on the reckoning that the only Philosophy of Education that can contribute to the construction of the reflexive and deliberant subject and of the democratic space is that which questions itself incessantly. Then, among other ones, the guideless proposed for this course referred to the placing of a crisis of truths and certainties of both the teachers and the students, as well as the desire for autonomy/citizenship/democracy.

Keywords: Philosophy of Education. Autonomy and Limitless Questioning. 


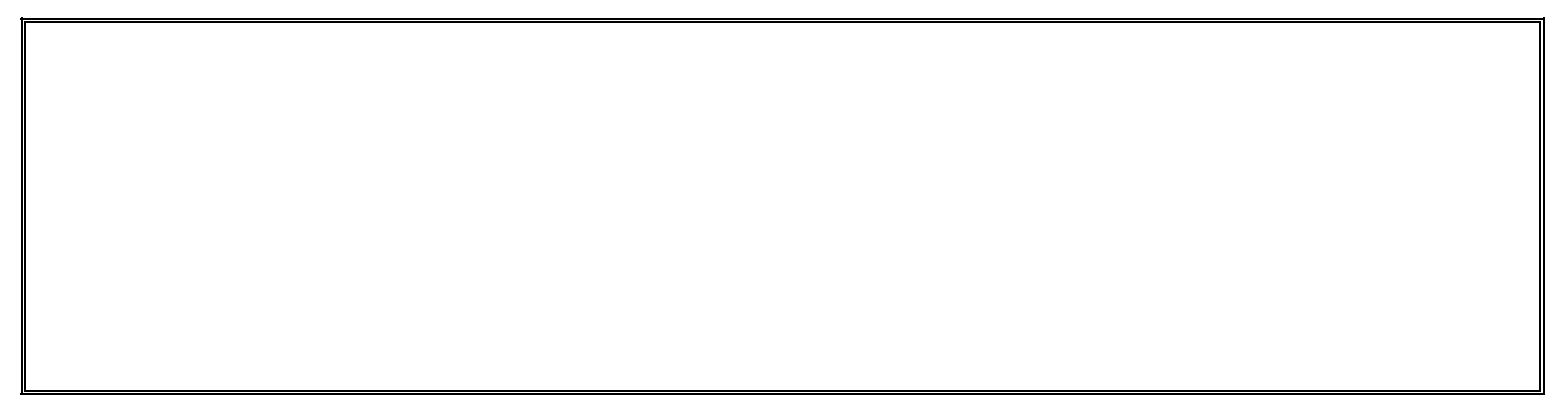




\section{LISTA DE SIGLAS}

ANFOPE Associação Nacional pela Formação dos Profissionais da Educação

ANPED Associação Nacional de Pesquisa e Pós-graduação em Educação

CAP-COLUNI Colégio de Aplicação Coluni

$\mathrm{CCH} \quad$ Centro de Ciências, Humanas, Letras e Artes

CEPE/UFV Conselho de Ensino, Pesquisa e Extensão da Universidade Federal de

Viçosa

CFE Conselho Federal de Educação

CNBB Conferência Nacional dos Bispos do Brasil

CNE Conselho Nacional de Educação

$\mathrm{CNE} / \mathrm{CP} \quad$ Conselho Nacional de Educação/Conselho Pleno

CNE/CES Conselho Nacional de Educação/ Câmara de Educação Superior

CONARCFE Comissão Nacional de Reformulação dos Cursos de Formação do

Educador

CONSU Conselho Universitário

CTG Conselho Técnico de Graduação

DCN's Diretrizes Curriculares Nacionais

DED Departamento de Economia Doméstica

EMATER Empresa de Assistência Técnica e Extensão Rural

ESCD Escola Superior de Ciências Domésticas

FEUSP Faculdade de Educação da Universidade de São Paulo

FFCL Faculdade de Filosofia, Ciências e Letras

FGV Fundação Getúlio Vargas

FNFi Faculdade Nacional de Filosofia

FUFAM Fundação Universidade da Amazônia

ICES Instituto Católico de Estudos Superiores

IEUSP Instituto de Educação da Universidade de São Paulo

ISES Instituto Superior de Educação

JUC Juventude Universitária Católica

LDB Lei de Diretrizes e Bases da Educação Nacional

LEC Liga Eleitoral Católica

MEC Ministério da Educação 
MEC/USAID Ministério da Educação/United States Agency for International

Development

MG

Minas Gerais

PAC

Pró-Reitoria Acadêmica

PPG

Pró-Reitoria de Pesquisa e Pós-Graduação

PRE Pró-Reitoria de Ensino

PUC-RS Pontifícia Universidade Católica do Rio Grande do Sul

PUC-SP Pontifícia Universidade Católica de São Paulo

SESU Secretaria de Educação Superior

UB

Universidade do Brasil

UCG

Universidade Católica do Goiás

UDF

Universidade do Distrito Federal

UERJ

Universidade do Estado do Rio de Janeiro

UFBA Universidade Federal da Bahia

UFC Universidade Federal do Ceará

UFJF Universidade Federal de Juiz de Fora

UFG Universidade Federal de Goiás

UFMG Universidade Federal de Minas Gerais

UFPA Universidade Federal do Pará

UFRGS Universidade Federal do Rio Grande do Sul

UFRJ Universidade Federal do Rio de Janeiro

UFSC Universidade Federal de Santa Catarina

UFSCar Universidade Federal de São Carlos

UFSM Universidade Federal de Santa Maria

UFU Universidade Federal de Uberlândia

UFV Universidade Federal de Viçosa

UNICAMP Universidade Estadual de Campinas

UNIMEP Universidade Metodista de Piracicaba

UNESP Universidade Estadual Paulista Júlio de Mesquita Filho

UREMG Universidade Rural do Estado de Minas Gerais

USP Universidade de São Paulo 


\section{SUMÁRIO}

1 INTRODUÇÃO

1.1 Encontro pessoal com a Filosofia da Educação 15

1.2 Encontro teórico com a Filosofia da Educação 18

2 O SOCIAL-HISTÓRICO: AS DIMENSÕES INSTITUINTE E NSTITUÍDO E OS PROCESSOS DE SOCIALIZAÇÃO E INDIVIDUAÇÃO 23

3 PARA COMPREENDER A FILOSOFIA DA EDUCAÇÃO

3.1 A institucionalização do monopólio legislativo do Estado sobre a educação 43

3.2 A institucionalização da formação de professores $\quad 50$

3.3 A tentativa de cientismo da educação $\quad 55$

4 A DISCIPLINA FILOSOFIA DA EDUCAÇÃO ..

4.1 A institucionalização da disciplina Filosofia da Educação no Brasil 67

4.2 A identidade da disciplina Filosofia da Educação: uma construção instituída 72

5 A DISCIPLINA FILOSOFIA DA EDUCAÇÃO NA UNIVERSIDADE FEDERAL DE VIÇOSA

5.1 O Curso de Pedagogia na Universidade Federal de Viçosa 115

$\begin{array}{lll}\text { 5.2 Das disciplinas de Filosofia da Educação } & 127\end{array}$

5.3 As representações e os pensamentos dos ufevianos sobre a Filosofia da Educação 137

6 A FILOSOFIA DA EDUCAÇÃO: ELUCIDAÇÃO DO FENÔMENO EDUCATIVO E POSSIBILIDADE DE AUTONOMIA 149

7 CONSIDERAÇÕES FINAIS 166

REFERÊNCIAS

$\begin{array}{ll}\text { ANEXO A } & 186\end{array}$

$\begin{array}{lr}\text { ANEXO B } & 195\end{array}$

$\begin{array}{ll}\text { ANEXO C } & 198\end{array}$

$\begin{array}{ll}\text { ANEXO D } & 202\end{array}$ 
ANEXO E

ANEXO F

ANEXO G

ANEXO H 


\section{INTRODUÇÃO}

É somente a partir dessa convicção, profunda e impossível, da
mortalidade de cada um de nós e de tudo o que fazemos, que se
pode viver como ser autônomo - e que uma sociedade
autônoma se torna verdadeiramente possível.

Castoriadis

\subsection{Encontro pessoal com a Filosofia da Educação}

Nasci em uma pequena cidade da Zona da Mata de Minas Gerais, chamada Tocantins, onde ocorreu a minha formação escolar nos atuais ensinos fundamental e médio das escolas públicas da cidade.

Talvez por influência da escola e pelo exemplo de minha irmã, que assumiu a chefia da família, após morte de nosso pai, eu tenha optado pelo Curso de Magistério, em nível de ensino médio.

E foi assim que se iniciou a minha trajetória intelectual.

Refente à profissão, meu primeiro emprego, para fugir da influência da minha família, foi no município de Ubá, na Escola Estadual Polivalente, em 1976, quando trabalhei como auxiliar de biblioteca.

Posteriormente, atuei no Ensino Fundamental da Escola Estadual Capitão Antônio Pinto de Miranda e da Escola Estadual Deputado Carlos Peixoto Filho. Foi uma excelente oportunidade para eu conhecer a escola e sua clientela. Contudo, minha formação não me permitiu interrogar a respeito da escola e das políticas públicas para a educação, nem sobre a finalidade do processo educativo. Ministrava aulas pelo desejo de ver as crianças aprenderem. Todavia, a situação de trabalho era por meio de contratos temporários, e não havia perspectiva de realização de concurso para efetivação no cargo. Assim, em 1978 ingressei-me na Empresa de Assistência Técnica e Extensão Rural do Estado de Minas Gerais (EMATER-MG), onde desempenhei a função de Secretária por 10 anos. Foi uma oportunidade ímpar de conhecer os problemas do meio agrário e iniciar minha militância em órgãos de classe. Tal período da minha vida culminou na minha demissão, em 1988, por liderança de greves. Concomitantemente, no período de 1979 a 1991 continuei vinculada à área de educação, na Escola Estadual Dr. João Pinto, ministrando aulas de Sociologia da Educação, Fundamentos 
da Educação I, Fundamentos da Educação II, Aspectos Biopsicológicos da Educação, História da Educação, Estrutura e Funcionamento do Ensino e Metodologia.

Após minha demissão da EMATER-MG, incomodada com a perspectiva que estava assumindo o Serviço de Extensão Rural Público, pleiteei, com sucesso, meu mestrado na Universidade Federal de Viçosa (UFV), em Extensão Rural, objetivando a um estudo comparativo entre a extensão rural pública e a extensão rural em uma organização nãogovernamental.

Durante o Mestrado, procurei aproximar do Departamento de Educação da UFV para complementar a minha formação pedagógica. Assim, cursei a única disciplina oferecida Psicologia Social, na qual se discutiu e analisou o livro de Alex Leontiev.

Durante o período do mestrado, houve uma série de aposentadorias na UFV decorrentes das políticas governamentais, oportunidade em que prestei concurso para o Departamento de Educação e fui bem-sucedida.

A partir daí, minha trajetória profissional na UFV tem se fundamentado na busca de uma autoformação para suprir lacunas de minha graduação e em reflexões incessantes sobre a Educação e a Filosofia da Educação.

Meus contatos com a disciplina surgiram da forma que se apresenta nos parágrafos subsequentes.

O primeiro deu-se, ainda, no curso de Magistério, em nível de $2^{\circ}$ grau (atual ensino médio), cuja professora também ministrava História da Educação e não fazia distinção entre as duas disciplinas, mantendo um programa de História da Educação com referência a alguns filósofos. O segundo, na graduação em Pedagogia (1975-1978), na Faculdade de Filosofia, Ciências e Letras de Ubá, quando também a disciplina de Filosofia da Educação foi ministrada com ênfase no primeiro termo da locução, com a utilização de uma apostila elaborada pela professora. O terceiro, quando, na década de 1980, ministrei "Fundamentos da Educação", no curso de Magistério da Escola Estadual Dr. João Pinto em Tocantins, e utilizei livros didáticos recebidos pela escola e aporte de algum material da disciplina cursada na faculdade. Nesse momento, não tinha consciência do que era a disciplina e nem de sua importância na formação dos professores. O quarto contato surgiu quando, por indicação da minha professora de Filosofia da Educação na graduação, a faculdade convidou-me para substituí-la, dado seu impedimento por motivo de saúde. Aceitei e, ao utilizar o mesmo material, começaram as minhas interrogações sobre qual o sentido de saber o que falou tal ou qual filósofo sobre a Educação se nem mesmo se pensava o social-histórico em que havia sido produzida tal teoria, de que concepção filosófica era tributária, e nem o conceito de educação 
presente em cada um. Nesse período, iniciaram-se minhas buscas de literaturas afins, sem saber por onde começar e o que era válido e o que não era. Nesse momento, a obra do Professor Antônio Joaquim Severino, recebida de presente, foi fundamental para dar sustentabilidade às minhas interrogações. O quinto contato ocorreu em 1986, no curso de pósgraduação lato sensu, ministrado pelo Departamento de Educação da Universidade Federal de Viçosa, por meio de frequência na disciplina EDU 341 - Fundamentos Filosóficos da Educação. Nessa matéria, o professor apresentou uma série de livros concernentes à área de Filosofia e Educação, o que não eliminou a sensação de carência de um sentido para a própria disciplina. $\mathrm{O}$ que se obteve foi o acesso à indicação de literaturas, ainda que sem discussão, mas a questão do que é Filosofia da Educação, da sua identidade e do seu papel na formação do docente também não foi solucionada.

Em 1989, ao cursar o Mestrado em Extensão Rural na Universidade Federal de Viçosa, sempre tendo a questão da Educação como central, busquei frequentar as disciplinas oferecidas pelo Departamento de Educação como optativas. Contudo, não havia nenhuma disciplina de Filosofia ou Filosofia da Educação ou Epistemologia das Ciências.

No início da década de 1990, submeti-me a um concurso público para professora do Departamento de Educação, mediante Edital de concurso na área de Fundamentos da Educação - História e Filosofia da Educação. Desde que fui aprovada, venho atuando na área de Filosofia da Educação, ministrando as disciplinas de Introdução à Filosofia, Filosofia da Educação, Ética e Concepção Filosófica da Educação. Trabalhei com os programas analíticos das disciplinas de Introdução à Filosofia e Filosofia da Educação e, posteriormente, sem propor alteração nos programas analíticos, fui redesenhando as disciplinas, seu conteúdo e suas referências bibliográficas. Aguardava a reformulação do Curso de Pedagogia, em discussão, para propor alteração dos programas analíticos, o que só se concretizou em 1999, quando estava afastada do Departamento para exercer o cargo de Chefe da Divisão de Assuntos Culturais da UFV, não tendo, por isso, participado daquela reformulação. Todavia, a disciplina de Concepção Filosófica da Educação, quando foi por mim estruturada, já o foi para discutir o sentido, identidade e papel da Filosofia da Educação.

Para fundamentar minha interrogação latente sobre a disciplina, filiei-me à Associação Nacional de Pesquisa e Pós-Graduação (ANPED) e passei a freqüentá-la, participando do Grupo de Trabalho no 17 - Filosofia da Educação.

Em 1997, iniciei a organização e efetivação dos Colóquios de Filosofia e de Filosofia da Educação na Universidade Federal de Viçosa, objetivando fomentar a discussão filosófica 
e educacional. A partir desses eventos, foi organizado um livro com as conferências, intitulado "Filosofia, Educação e Imaginário".

Em 1998, frequentei, na qualidade de ouvinte do Curso de Mestrado em Educação na Universidade do Estado do Rio de Janeiro (UERJ), as disciplinas "Concepções Filosóficas da Educação" e "Autonomia e Instituição - Cornelius Castoriadis e as Encruzilhadas do Labirinto V”, ministradas pela Professora Lílian de Aragão Bastos do Valle.

Durante a minha atividade docente na Universidade Federal de Viçosa, além de participar de diversas comissões internas e externas do Departamento de Educação, da Comissão Permanente de Pessoal Docente da UFV, do Conselho Técnico de Graduação, da Câmara Curricular do Centro de Ciências Humanas, Letras e Artes, do Conselho Técnico de Extensão, da Chefia da Divisão de Assuntos Culturais da UFV, do Conselho Municipal de Educação, do Conselho Municipal da Cultura e do Patrimônio Cultural e Ambiental de Viçosa, assumi, por duas gestões, a Coordenação do Curso de Pedagogia da UFV, o que foi mister para conhecer a história do curso e suas mudanças e reforçar meu objeto de estudo para o doutorado. Além das atividades de ensino, desenvolvi, ainda nesse período, trabalhos de pesquisa e extensão nas áreas de Educação, Filosofia e Filosofia da Educação.

Além das interrogações que me acompanham, foram fatores determinantes na definição do objeto de pesquisa o Projeto do Departamento de Criação de um Mestrado em Educação e o Regimento de Admissão, Promoção e Aperfeiçoamento de Pessoal Docente da UFV (1996), em seus artigos de $n^{\circ}$ s. 48 e 49 e respectivos parágrafos únicos.

Ponderei que, por coerência com o meu discurso e em respeito à res pública, deveria eleger, como objeto de estudo, a área de conhecimento para a qual me submeti ao concurso para professora da UFV - Fundamentos da Educação: História e Filosofia da Educação. Assim, como trabalho as disciplinas de Concepção Filosófica da Educação e Ética, priorizei a questão que historicamente tem me incomodado - o papel da disciplina Filosofia da Educação na formação do pedagogo.

\subsection{Encontro teórico com a Filosofia da Educação}

O professor encontra-se em um momento de parar, de estranhar a própria prática, refletindo sobre o problema dela decorrente, no sentido de elucidá-lo e contribuir, teórica ou praticamente, para o campo da ação que exerce. 
Com base nessa assertiva e em razão das interrogações suscitadas no processo de formação e na prática educativa exercida na Universidade Federal de Viçosa, no Departamento de Educação elegeu-se, como objeto de pesquisa, a disciplina Filosofia da Educação.

Assim, constituem objetivos deste trabalho a análise da possibilidade de contribuição da Filosofia da Educação na construção, pelos educandos, de sua autonomia e a proposição de um projeto para a disciplina.

A idéia, essencialmente política, da obra e da prática de Castoriadis permitirá pensar a educação como possibilidade de construção de autonomia.

Fundamentada, pois, em suas reflexões e nas de outros filósofos expressivos, o caminho seguido neste trabalho apresentará cinco tópicos.

No primeiro capítulo, buscará na obra de Castoriadis a elucidação de como a sociedade, pelo imaginário social, se cria e cria seus indivíduos, instituindo o fazer e o representar/dizer social, os quais se fazem nas dimensões imaginária e conjuntista-identitária. A dimensão imaginária efetiva-se em um magma de significações imaginárias sociais que estruturam as representações do mundo em geral, que serão internalizadas pelo psiquismo humano, no processo de socialização, designando as finalidades da ação e impondo o que se pode fazer ou não fazer. A dimensão conjuntista-identitária do social-histórico efetiva-se na instituição do legein e do teukhein sobre o fazer/representar/dizer social.

O processo de socialização da psique, para torná-la indivíduo social, garantia da autoconservação e do autocentrismo da sociedade, não se concretiza in totum; há sempre resistência da psique, que pode se manifestar como imaginação radical.

E é na imaginação radical que se encontra a possibilidade, principalmente por meio da paidéia e do nomos, de construção do sujeito humano, cujos atributos são a reflexividade e a vontade, as quais permitem a criação da atitude de interrogação de si e da sociedade.

O segundo capítulo será uma tentativa de compreender a institucionalização da disciplina Filosofia da Educação na formação dos educadores no Brasil, à luz dos processos da institucionalização do monopólio legislativo do Estado na educação, da institucionalização da formação de professores, com a criação da Faculdade de Educação, em 1931, e do curso de Pedagogia, em 1939, e a tentativa de cientismo da educação.

Para tal, é imprescindível pensar no seu desenvolvimento histórico.

A institucionalização da República brasileira, em 1889, que se efetivou sem a participação do povo, nas instâncias de decisão das esferas econômicas e políticas, resultou sem alteração ou criação de instâncias deliberativas democráticas. 
O projeto educacional republicano, que concebia a instrução como um meio de transformar o súdito em cidadão, não se concretizou. Dos princípios da Escola Pública, a obrigatoriedade da educação não se efetivou, ficando a escolarização à mercê da vontade individual de cada um.

Ressalte-se que, embora uma série de reformas educacionais tenham sido instituídas, até o governo provisório, não existia um sistema de ensino nacional organizado. Em 1930, um conjunto de atos legislativos, imposto a todo o território nacional, cria o Conselho Nacional de Educação, que define a organização da Universidade do Rio de Janeiro e do ensino superior no Brasil.

A institucionalização da formação de professores também se dá pelo conjunto de decretos da Reforma Francisco Campos - n. ${ }^{\text {os }} 19.850$, 19.851 e 19.852; além dos decretos n. ${ }^{\text {os }}$ 19.890 e 21.241, que dispõem a organização do ensino secundário e, em especial, do Decreto n. ${ }^{\text {o. }} 1.190$, de 4 de abril de 1939, que dá organização à Faculdade Nacional de Filosofia da Universidade do Brasil, que compreendia, além de outras, a seção de Pedagogia, responsável pelo curso do mesmo nome, que é criado.

A formação de professores no Brasil tem, assim, o seu modelo fixado pelo DecretoLei n. ${ }^{\circ}$ 1.190, mas, o Estado, por meio do Conselho Federal de Educação, ainda determinará sobre o curso de Pedagogia, em 1962, com a Resolução CFE n. ${ }^{\circ} 62$ e Parecer n. ${ }^{\circ}$ 251, fixando o currículo mínimo e a duração do curso; e em 1969, com a Resolução CFE n. ${ }^{\text {o }}$ 2/69 e o Parecer n. ${ }^{\circ}$ 252/69, definindo dupla função para o curso, qual seja, a formação de professores e a formação de especialistas. Em 2006, o Estado intervém no curso quando a SESU/MEC institui as diretrizes curriculares deste, consubstanciadas na Resolução CNE/CP n. ${ }^{\circ}$ 01, de 15 de maio de 2006.

Será abordada ainda neste capítulo, a tentativa de adoção da perspectiva cientificista na educação, que surge no final do século XIX e que no Brasil, nas décadas de 20 e 30, traduz-se no movimento da Escola Nova, capitaneado pelos Pioneiros da Educação, dentre eles, Anísio Teixeira, Fernando de Azevedo e Lourenço Filho, que se responsabilizaram por reformas educacionais em diversos estados.

A educação faz-se, então, perpassar pela ideologia e pela mitologia da ciência, com a introdução nos currículos de disciplinas, princípios e práticas que se apoiam na ideia de que a ciência tudo pode e que só tem validade o que foi submetido a procedimentos científicos.

No terceiro capítulo, terão ênfase as raízes da institucionalização da disciplina Filosofia da Educação no Brasil e a discussão suscitada sobre sua identidade. 
A disciplina surge no Instituto Pedagógico, em 1931, posteriormente transformado em Instituto de Educação e incorporado à Universidade de São Paulo, em 1934, nos cursos de Administradores Escolares. É, também, ministrada nos cursos de formação de Professor Primário e de Professor Secundário, com o nome de História e Filosofia da Educação, em 1936.

No Rio de Janeiro, a disciplina compõe o currículo da Escola de Professores, do Instituto de Educação, o qual é incorporado à Universidade do Distrito Federal.

Mas é com a criação da Faculdade Nacional de Filosofia da Universidade do Brasil, mediante o decreto n. ${ }^{\circ} 1.190$, de 4 de abril de 1939, em que se institui o curso de Pedagogia, que o governo federal define a obrigatoriedade do ensino da Filosofia da Educação, que prevalecerá até 2006, quando as diretrizes curriculares do curso de Pedagogia são instituídas, mas sem especificar nenhum conteúdo ou disciplina obrigatória.

No que concerne à identidade da disciplina Filosofia da Educação, pressupõe-se pensá-la como criação da realidade social-histórica, por atores que com ela se relacionam.

Mas a identidade com que a disciplina historicamente se apresentou tem sido objeto de questionamentos. Para discuti-los, será examinada a literatura de alguns estudiosos que se debruçaram sobre tal temática, inclusive propondo alguns modelos para a disciplina.

A contribuição de Cornelius Castoriadis para elucidar a educação será também objeto da investigação.

No quarto capítulo, as disciplinas de Filosofia da Educação do curso de Pedagogia, do Departamento de Educação da Universidade Federal de Viçosa (UFV), constituirão o material empírico para análise, por guardar identificação/semelhança com seus congêneres de outras instituições.

Para tal, será pertinente refletir sobre o histórico do curso de Pedagogia da UFV, criado em 1971, vinculado ao Departamento de Metodologia da Escola Superior de Ciências Domésticas e programas analíticos das disciplinas de Filosofia da Educação, historicamente presentes no currículo do curso, bem como as representações dos atores ufevianos - dirigentes acadêmicos e professores - sobre as disciplinas.

A pesquisa empírica privilegiará as fontes Catálogos de Graduação da UFV; processos acadêmicos de criação e reconstrução do curso de Pedagogia; projetos político-pedagógicos da Pedagogia; programas analíticos das disciplinas de Filosofia da Educação; Banco de dados de ensino da UFV (http://www.cpd.ufv.br/ensino); Sistema Gestor de Pesquisa da UFV (http:cpd.ufv.br/pesquisa); Pró-Reitoria de Planejamento e Orçamento - Publicações envolvendo docentes da UFV (http://www.cpd.ufv.br/publicaçoes): Plataforma Lattes/CNPq. 
Envolverá, ainda, entrevista com professores, comportando itens sobre formação acadêmica do professor (graduação, especialização, mestrado e doutorado) e questionado se a formação acadêmica viabiliza sua atuação, como professor de Filosofia da Educação; o que pensa sobre a disciplina e que papel atribui a ela no curso de Pedagogia; como age em relação aos programas analíticos oficiais, quando atua na disciplina; qual a contribuição para a construção da identidade da disciplina. A entrevista se estenderá, igualmente, aos pró-reitores de ensino, aos diretores do Centro de Ciências Humanas, Letras e Artes/Presidente da Câmara Curricular, aos coordenadores do curso de Pedagogia e aos chefes do Departamento.

No quinto capítulo, com apoio no pensamento de Castoriadis e Valle, analisar-se-ão a educação, como atividade prático-poiética, e a Filosofia da Educação, como interrogação incessante, como instituição de uma política de autonomia.

Esse capítulo encerrará com uma proposta para a disciplina Filosofia da Educação, que engloba: crise das verdades e das certezas dos educadores e dos educandos; manifestação do desejo de autonomia/cidadania/democracia; conhecimento/estudo permanente da História da Filosofia da Educação pelo educador; elaboração pelo educador, de um projeto para seus educandos; prestação de contas públicas pelo educador do que pensa, diz e faz de sua prática pedagógica e interrogação ilimitada de si, do outro e da sociedade - das significações imaginárias sociais - pelo educador e pelos educandos.

Espera-se que o desenvolvimento desses tópicos conduza à reflexão das reais possibilidades de a Filosofia da Educação exercer seu verdadeiro papel na prática educativa dos professores, na construção de autonomia do educando. 


\title{
2 O SOCIAL-HISTÓRICO: AS DIMENSÕES INSTITUINTE E INSTITUÍDO E OS PROCESSOS DE SOCIALIZAÇÃ̃ E INDIVIDUAÇÃO
}

\author{
Criando-se, a sociedade cria o indivíduo e os indivíduos em e \\ pelos quais somente ela por ser efetivamente.
}

Castoriadis

Neste trabalho, parte-se da perspectiva de que a sociedade se autocria, por ser a criação de indivíduos sociais; e estes, por sua vez, criam as instituições - sendo a primeira delas a eles próprios, além da linguagem, da cultura, da religião, das leis e de todo o conjunto de significações sociais que lhes permitem viver, pensar, sentir e agir. Produzem-se assim modos particulares de viver, que imprimem um caráter singular a cada sociedade. Portanto, a sociedade é, em sua gênese, autocriação: ela é instituinte, fazendo vir à cena algo até então não existente como instituição, indivíduo, leis, objetos, cultura etc.

Assim, a sociedade se autoinstitui:

O autodesenvolvimento do imaginário radical como sociedade e como história como o social-histórico - faz-se e só pode se fazer em e pelas duas dimensões do instituinte e do instituído. A instituição, no sentido fundador, é criação originária do campo social-histórico - do coletivo anônimo - que ultrapassa como eidos, toda "produção" possível dos indivíduos ou da subjetividade. O indivíduo - e os indivíduos - é instituição, instituição de uma vez por todas e instituição cada vez diferente, em cada sociedade diferente. É o pólo a cada vez especificado da imputação e da atribuição sociais normalizadas, sem o que não pode haver sociedade (CASTORIADIS, 1992, p. 121).

A criação da sociedade efetiva-se com o autodesenvolvimento do imaginário radical, isto é, do poder criador de um coletivo social sempre anônimo, que institui o seu mundo próprio, o magma de significações imaginárias que a sociedade compartilha. E o que é o imaginário que detém esse poder instituinte? O imaginário é para o autor:

\footnotetext{
Esse elemento, que dá à funcionalidade de cada sistema institucional sua orientação específica, que sobredetermina a escolha e as conexões das redes simbólicas, criação de cada época histórica, sua singular maneira de viver, de ver e de fazer sua própria existência, seu mundo e suas relações com ele, esse estruturante originário, esse significado - significante central, fonte do que se dá cada vez como sentido indiscutível e indiscutido, suporte das articulações e das distinções do que importa e do que não importa, origem do aumento dos objetos de investimento prático, afetivo e intelectual, individuais ou coletivos - este elemento nada mais é do que o imaginário da sociedade ou da época considerada (CASTORIADIS, 1982, p. 175).
}

Assim, é o imaginário radical, imaginação produtiva ou criadora da sociedade como tal, a instância instituinte do universo de significações sociais - magma que fornece a cada sociedade a sua singularidade, já que se efetiva em um fazer, dizer, representar a sua própria existência. Assim, o imaginário radical - cujos atributos são a construção de um mundo 
próprio, a finalidade de autoconservação e o autocentrismo - é criação. Deve-se pensar as instituições que ele cria na perspectiva de "[...] uma rede simbólica, socialmente sancionada, onde se combinam em proporções e em relações variáveis um componente funcional e um componente imaginário" (CASTORIADIS, 1982, p. 159). Nesse sentido, são pertinentes as afirmações do filósofo:

Nascida em, por e como uma ruptura do tempo, manifestação da auto-alteração da sociedade instituinte, a instituição, no sentido profundo do termo, só pode ser colocando-se como fora do tempo, recusando sua alteração, colocando a norma de sua identidade imutável e colocando-se como norma de identidade imutável, sem o que ela não é. Dizer que a instituição pode prever, regular, gerar sua própria mudança é ainda dizer que ela a institui como sua não mudança própria, que ela pretende dirigir o tempo, que ela se recusa a ser alterada como instituição (CASTORIADIS, 1982, p. 251).

Desse modo, a instituição, rede simbólica-funcional, é uma criação do imaginário instituinte, que se consolida e cristaliza visando à sua autoconservação; isto é, ela se fecha em sua identidade para autopreservar-se, buscando impedir toda e qualquer mudança.

Pode-se, portanto, compreender que toda sociedade é resultante da obra do imaginário radical, que ela sempre é instituição, criação, autoalteração que se faz ser como sociedade instituída, como conjunto de criações que Castoriadis denominou "imaginário social". A sociedade é, pois, tanto o imaginário radical instituinte quanto o imaginário instituído.

Para Castoriadis (1982):

A instituição social histórica é aquilo em que e por que se manifesta e é o imaginário social. [...] O imaginário social é, primordialmente, criação de significações e criação de imagens ou figuras que são seu suporte. A relação entre a significação e seu suporte (imagens ou figuras) é o único sentido preciso que se pode atribuir ao termo simbólico [...]. (p. 277).

É o social-histórico, em sua dimensão instituinte - imaginário radical - que cria, funda o sentido, as significações sociais, assim denominadas por serem criações jamais correspondendo ou se deixando esgotar em elementos racionais e reais; e por existirem como realidades instituídas, que são comuns a todos que participam da sociedade. Assim, sociedade e significação são sua própria origem, são autocriação.

E como se estruturam as significações imaginárias sociais criadas e instituídas pelo imaginário? Para respondê-lo, o autor de A instituição imaginária da sociedade recorre à metáfora do magma, e assim define a relação que estabelecem entre si:

Só podemos descrevê-la como um feixe indefinido de remissões intermináveis a outra coisa que (o que apareceria como imediatamente dito). Estas outras coisas são sempre tanto significações como não significações - aquilo a que se referem ou se relacionam às significações. [...] Mas o léxico das significações é universalmente aberto: porque a significação plena de uma palavra é tudo aquilo que, a partir ou a 
propósito desta palavra, pode ser socialmente dito, pensado, representado, feito. (1982, p. 283-284).

Castoriadis insiste em diferenciar, porém, as significações imaginárias sociais dos símbolos em que, até certo ponto, elas também podem se constituir: as

[...] significações... não se encontram aí para representar [uma] outra coisa [qualquer, elas] são as articulações últimas que a sociedade em questão impôs ao mundo, a si mesmo e a suas necessidades, [e também] os esquemas organizadores que são a condição de representabilidade de tudo que essa sociedade pode se dar. Mas, por sua própria natureza, esses esquemas não existem sob a forma de uma representação que poderíamos atingir através de análises.

As significações imaginárias sociais - pelo menos as que são verdadeiramente últimas - não denotam nada, e conotam mais ou menos tudo; e é por isso que elas são tão frequentemente confundidas com seus símbolos, não somente pelos povos que as utilizam, mas pelos cientistas que as analisam e que chegam, por isso, a considerar que seus significantes se significam por si mesmo (uma vez que não remetem a nenhum real, nenhum racional que pudéssemos designar) e a atribuir a esses significantes como tais, ao simbolismo tomado em si mesmo, um papel e uma eficácia infinitamente superiores às que certamente possuem (1982, p. 173).

As significações imaginárias sociais desempenham fundamental papel: ao constituírem um sistema que valoriza e desvaloriza, estrutura e hierarquiza um conjunto cruzado de objetos e de faltas correspondentes, são elas que

[...] estruturaram as representações do mundo em geral, sem as quais não pode haver ser humano, $[\ldots]$ designam as finalidades da ação, impõem o que está por fazer e por não fazer, o que ou não ser feito: [...] estabelecem os efeitos característicos de uma sociedade" (CASTORIADIS, 2002, p. 148).

Assim, como já se evidenciou aqui, instituição, imaginário social e imaginação radical, realidade instituinte e instituída, criação, significações imaginárias sociais, lógica conjuntista-identitária, legein e teukhein são conceitos centrais em Castoriadis. É o imaginário social o responsável pela instituição/criação da sociedade ou, como o autor a denomina, do social-histórico, através da posição/criação das significações imaginárias sociais; em sua dimensão individual, essa criação se faz pela imaginação radical. $\mathrm{Na}$ Instituição Imaginária da Sociedade, o autor apresenta a ecceidade de sua elaboração teórica, qual seja, a existência da sociedade como fazer/representar do coletivo anônimo, tomando das dimensões instituinte e instituído:

O social-histórico é o coletivo anônimo, o humano-impessoal que preenche toda formação social dada, mas também a engloba, que insere cada sociedade entre as outras e as inscreve todas numa continuidade, onde de certa maneira estão presentes as que não existem mais, as que estão alhures e mesmo as que estão por nascer. É por um lado, estruturas dadas, instituições e obras "materializadas", sejam elas materiais ou não; e por outro lado, o que estrutura, institui, materializa. Em uma palavra, é a união $e$ a tensão da sociedade instituinte e da sociedade instituída, da história feita e da história se fazendo (CASTORIADIS, 1982, p. 131). 
Tanto quanto as demais, a sociedade brasileira é criação de um coletivo anônimo; e é tributária de estruturas, instituições e obras da sociedade portuguesa, da francesa, da alemã, da italiana, enfim, das sociedades europeias e de suas raízes greco-romanas, mas também tributária das criações afros e indígenas. A sociedade brasileira institui-se, e ainda que colonizada, cria suas próprias significações imaginárias - o que a torna, como todo socialhistórico, única.

Há, porém, algo que a sociedade brasileira necessariamente compartilha com as demais sociedades: trata-se da dimensão lógica, que Castoriadis denomina de "conjuntista identitária" - porque atua como exigência de determinação de "identidades" e de relações entre identidades para tudo o que existe - e que se faz presente no fazer e no representar/dizer social. E, de fato, a lógica determina, até certo ponto, a linguagem e o fazer humano: no vocabulário de Castoriadis, o legein (que vem do logos, da linguagem) e o teukhein (que deriva de fazer - em grego, tekhné). Mas isso, evidentemente, até certo ponto, porque a lógica conjuntista identitária não domina sozinha o fazer/representar/dizer humano, que se singulariza por sua dimensão imaginária - caso contrário, não se teriam sociedades, mas uma só sociedade. Entretanto, sem a dimensão conjuntista-identitária (conídica, diz Castoriadis), não haveria tampouco sociedade:

\begin{abstract}
A lógica-ontologia herdada está solidamente ancorada na própria instituição da vida social-histórica; ela se enraíza nas necessidades inelimináveis desta instituição, ela é, em certo sentido, elaboração e arborescência dessas necessidades. Seu núcleo é a lógica identitária ou conjuntista, e esta lógica que impera soberanamente e inevitavelmente em duas instituições sem as quais não há vida social; a instituição do legein, componente ineliminável da linguagem e do representar social, a instituição do teukhein, componente ineliminável do fazer social. $\mathrm{O}$ fato de que uma vida social tenha podido existir mostra que esta lógica identitária ou conjuntista tem apoio no que existe - não somente no mundo natural no qual a sociedade surge, mas na própria sociedade, que não pode representar e se representar, dizer e se dizer, fazer e se fazer sem colocar em ação também esta lógica identitária ou conjuntista, que só pode instituir e se instituir instituindo também o legein e o teukhein. [...] Porque a lógica identitária é lógica da determinação, se especifica segundo os casos como relação de causa e efeito, de meio a fim ou de implicação lógica (1982, p. 210).
\end{abstract}

Por se constituírem nas dimensões estruturadoras da instituição social-histórica, o legein e o teukhein, consubstanciais à lógica identitária, significam a própria forma de captação, percepção e tematização do mundo - pela linguagem e pela instituição da técnica como fazer social. Para Maciel (1987), “[...] na instituição da sociedade, o legein aparece como a dimensão conjuntista-conjuntizante do representar/dizer social, ao mesmo tempo em que o teukhein (juntar-ajustar-fabricar-construir) aparece como a dimensão conjuntistaconjuntizante do fazer social.” (p. 168). 


\title{
Dessa forma:
}

A instituição da sociedade é instituição do fazer social e do representar/dizer social. Nesses dois aspectos, ela comporta, ineliminavelmente, uma dimensão identitáriaconjuntista, que se manifesta no legein e no teukhein. O teukhein é a dimensão identitária (que podemos também denominar funcional ou instrumental) do fazer social; o legein é a dimensão identitária do representar/dizer social que se apresenta especialmente na linguagem na medida em que a linguagem é também sempre, necessariamente, código. Mas vimos, também longamente, que a linguagem não pode ser somente código, que ela comporta ineliminavelmente uma dimensão significativa, referida ao magma de significações que é sempre também língua (CASTORIADIS, 1982, p. 405).

Isso significa que o social-histórico é criação dos homens, que se criando, instituem a linguagem, as leis, o conjunto de instituições e estruturas sociais, a religião, a cultura - enfim, as significações imaginárias que dão sustentação e cimentam o social-histórico. A criação é, portanto, a constituição do novo - e a esse novo corresponde, a cada vez, uma realidade “objetiva" e uma representação "simbólica". Em suas reflexões sobre a instituição, o autor acrescenta:

\begin{abstract}
A instituição é uma rede simbólica, socialmente sancionada, onde se combinam em proporções e em relações variáveis um componente funcional e um componente imaginário. A alienação é a autonomização e a dominância do momento imaginário na instituição que propicia a autonomização e a dominância da instituição relativamente à sociedade. Esta autonomização da instituição exprime-se e encarnase na materialidade da vida social, mas supõe sempre também que a sociedade vive suas relações com suas instituições à maneira do imaginário, ou seja, não reconhece no imaginário das instituições seu próprio produto. (CASTORIADIS, 1982, p. 159160).
\end{abstract}

Assim, como criação de um coletivo anônimo, do poder instituinte de uma coletividade, a sociedade é a instituição das significações imaginárias sociais, constituição de um mundo de sentidos que faz ser, unifica e dá identidade singular ao social-histórico. $\mathrm{O}$ magma de significações imaginárias sociais é internalizado pelo psiquismo humano, na fabricação do indivíduo social: é a partir dele que se designam, em última análise, as finalidades da ação humana, as exepctativas e projetos, as obrigações e exigências da vida comum, o que se pode ou não fazer. Todavia, todo esse processo de instituição da sociedade só existe, concretamente, pela encarnação e incorporação fragmentária e complementar, pelos indivíduos, da instituição e de suas significações imaginárias.

A sociedade é obra do imaginário instituinte. Os indivíduos são feitos, ao mesmo tempo que eles fazem e refazem, pela sociedade cada vez instituída: num sentido, eles são a sociedade. Os dois pólos irredutíveis são o imaginário radical instituinte o campo de criação social-histórico - de um lado, e a psique singular de outro. A partir da psique, a sociedade instituída faz a cada vez indivíduos - que, como tais, não podem fazer mais nada a não ser a sociedade que os faz. Somente assim a imaginação radical da psique chega a transpirar através dos estratos sucessivos da couraça social que é o indivíduo que a recobre e a penetra até um ponto-limite 
insondável, que há retroação do ser humano singular sobre a sociedade. (CASTORIADIS, 1992, p. 123).

A instituição dos indivíduos é uma atividade social, é o processo de socialização da psique ou de fabricação social, mediatizado por indivíduos já socializados.

Ao nascer, o humano é mais do que a "pura composição biológica": ele é psique. O humano distingue-se dos outros viventes por sua psique, sobre a qual agem as instituições da sociedade, provocando a internalização dos sentidos instituídos. Tal processo se efetiva pelas relações com a mãe - primeira porta-voz do mundo que pela linguagem, traz consigo, o mundo instituído. Assim, o vivente humano, enquanto psique, à medida que é fabricado socialmente e internaliza as significações do instituído, torna-se indivíduo social, isto é, "[...] a psique torna-se indivíduo unicamente na medida em ela sofre um processo de socialização".

Contrariamente à tradição que apresentou o indivíduo como oposto à sociedade, Castoriadis insiste que é de fato "a psique... [que é] irredutível à sociedade. [...] Mas a psique não pode sobreviver, a menos que sofra o processo de socialização o qual lhe impõe, ou que constrói ao redor dela as camadas sucessivas do que será, na sua face externa, o indivíduo" (CASTORIADIS, 1992, p. 57 e 274).

A psique humana é um para si: ela se apresenta como um mundo próprio, que sofre, por parte de indivíduos já socializados, e a começar pela figura materna, uma ação coercitiva, uma violência: mas é esse choque que permite que ela invista em sentidos "públicos", isso é, que ele faça existir como sentido para si as significações imaginárias sociais da sociedade em que vive. Nisso consiste, em grande parte, o processo de socialização, ou de formação humana.

Assim, a socialização é para Castoriadis (1992) a fabricação social dos indivíduos a partir de um material primeiro: a psique. O filósofo analisa as quatro dimensões que definem a existência humana ou, como ele diz, as quatro regiões ontológicas que comportam o para si: o vivente, a psique, o indivíduo (necessariamente social) e o social-histórico. Assim, o humano, quando nasce, é composição biológica e é psique, a qual será objeto de uma ação coercitiva da sociedade, em processo de socialização exercido por um representante - figura canônica da mãe - que recorre à linguagem da instituição para se comunicar com o infans.

A psique, diz-nos Castoriadis, é inicialmente sob a forma de uma mônada: fechada em si, auto-suficiente, ela é um para si na medida em que vive sob uma única injunção: a da conservação de sua homeostasia, de manter-se tal com está, o que significa, tal como é. O processo de socialização se inicia como reação pela qual a mônada é forçada a se abrir a sentidos outros - que são as manifestações daqueles que para ela passam a representar o 
mundo, mas que ela transforma imediatamente em objetos privativos de prazer. Por isso, a socialização não está concluída até que a psique - ou o indivíduo social que se forma por sua ruptura - aceite, sublimando seus desejos, investir em objetos públicos. Isso não se dá sem que o indivíduo aceite substituir o "prazer de órgão", isso é, a satisfação imediatamente realizada pela sensorialidade, pelo "prazer de representação", que existe e só se mantém, como construção coletiva da sociedade.

É assim que, pela socialização, a psique se torna um novo para si - o indivíduo social, capaz de internalização dos sentidos instituídos. É nesse sentido que, segundo Castoriadis, não há oposição entre indivíduo e sociedade, pois o indivíduo é resultado de uma fabricação social. Ele é, portanto, a encarnação de suas instituições e de suas significações imaginárias sociais. Mas há, sim, oposição entre esses para si - psique e sociedade - o que, ao mesmo tempo, determina a constante possibilidade de ruptura do processo de socialização, mas, por outro lado, torna possível a emergência da criatividade e da reflexividade humanas.

Todavia, conceito-chave na elaboração teórica de Castoriadis, a socialização é um processo que também permite à sociedade a autoconservação e o autocentrismo:

\begin{abstract}
Do ponto de vista psíquico, a fabricação social do indivíduo é um processo histórico, mediante o qual a psique é obrigada (seja suave ou brutalmente, trata-se sempre de uma violência feita à sua natureza própria) a abandonar (nunca total, mas suficientemente quanto à necessidade/uso social) seus objetos e seu mundo iniciais e investir objetos, um mundo, regras que são socialmente instituídas. Aqui está o verdadeiro sentido do processo de sublimação. O requisito mínimo para que o processo possa desenvolver-se é que a instituição ofereça à psique sentido - um outro tipo de sentido que não o proto-sentido da mônada psíquica. O indivíduo social constitui-se assim interiorizando explicitamente fragmentos importantes desse mundo, e implicitamente sua totalidade virtual pelas repercussões intermináveis que ligam magmaticamente cada fragmento desse mundo aos outros.

A vertente social desse processo é o conjunto das instituições, de que está impregnado constantemente o ser humano, desde o seu nascimento (CASTORIADIS, 1992, p. 125-126).
\end{abstract}

A fabricação social dos indivíduos apresenta-se pois, em duas vertentes: do ponto de vista psíquico, é um processo histórico, mediante o qual a psique é socializada e passa a investir em objetos comuns, no mundo e nas regras que são socialmente instituídos, sublimando seus objetos e seu mundo iniciais. Do ponto de vista social-histórico, ela se dá por ação de um conjunto das instituições que visam à formação humana, à iniciação dos recémchegados, àquilo que os gregos chamavam de paidéia: educação fornecida segundo a família, as classes de idade, aos ritos, aos costumes e leis etc. Assim, a fabricação social dos indivíduos só se efetiva à medida que estes interiorizam as instituições. Em outras palavras, a realidade social é um mundo de sentidos que se sustenta por formas instituídas e que penetra 
até ao âmago do psiquismo humano, modelando-o de forma decisiva, na quase totalidade de suas manifestações identificáveis.

Assim, pensa-se o indivíduo como instituição, fabricado por sua própria sociedade e atuando para também criá-la, mesmo que não tenha conhecimento/compreensão e lucidez acerca de tal processo.

A instituição da sociedade exerce poder sobre todos os indivíduos, o que faz com que, a ela submetidos, eles a tenham como a realidade mais completamente imediata, natural ou "espontânea", realizando nessa aceitação as consequencias de sua heteronomia. Nisso consiste o infra-poder exercido pela sociedade, sob a forma de:

[...] capacidade para qualquer instância que seja (pessoal ou impessoal), de levar alguém (ou vários) a fazer (ou a não fazer) o que, entregue a si mesmo, ele não faria necessariamente (ou faria talvez), e é imediato que o maior poder concebível é o de pré-formar alguém, de tal modo que por si mesmo ele faça o que queríamos que fizesse, sem nenhuma necessidade de dominação ou de poder explicito para levá-lo a [...] (CASTORIADIS, 1992, p. 126).

Dessa forma, a partir do nascimento, os indivíduos são pré-formados e passam a agir, pensar e sentir sem terem consciência de que, à medida que interiorizam as instituições da sua sociedade, passam a fazer o que se queria que eles fizessem, sem nenhuma necessidade de dominação. Pelo contrário, para os indivíduos, a sociedade e tudo o que internalizaram assume a aparência da mais completa "espontaneidade" e a realidade da total heteronomia.

O exercício do poder da instituição da sociedade sobre os indivíduos por ela produzidos efetiva-se por meio do conjunto de instituições que visam à socialização e que se realizam na família, na escola, nas leis, nos costumes, na religião e na cultura. Assim se transmitem as significações imaginárias sociais que, internalizadas pelos indivíduos, constituem a matriz de referência destes, fundamentando seu pensar, sentir e agir. Ao admitir o internalizado como natural e verdadeiro, sem jamais se questionar, o indivíduo realiza o movimento pelo qual toda sociedade impõe sua sobrevivência: o fechamento cognitivo.

Todavia, o infrapoder exercido sobre a psique de cada um pela sociedade instituída, no processo de socialização, nunca é absoluto. Uma série de fatores impede a fabricação do indivíduo social, de modo total e absoluto. Dentre eles, destacam-se:

[...] o mundo, enquanto mundo pré-social - limite do pensamento -, ainda que não "significando" nada em si mesmo, está sempre presente, como provisão inexaurível de alteridade, como risco sempre iminente de rasgadura no tecido das significações, com que a sociedade o vestiu (CASTORIADIS, 1992, p. 128-129),

isto é, o a-sentido do mundo ameaça sempre o sentido instaurado pela sociedade; mas, igualmente, a capacidade invencível da psique de preservar seu núcleo monádico e sua 
imaginação radical, que nunca poderá ser completamente socializada e transformada, exaustivamente, conforme o que as instituições lhe pedem; as outras sociedades e suas significações imaginárias sociais, que põem em perigo o sentido instaurado pela sociedade considerada; além disso, ameaça a sobrevivência da sociedade a ação do próprio imaginário radical da sociedade, isso é, do imaginário instituinte, pois a sociedade sempre contém, em sua instituição e suas significações imaginárias, um avanço em direção ao futuro, e o futuro exclui uma codificação prévia e exaustiva das decisões a serem tomadas.

Para preservar seu mundo próprio, seu para si, a sociedade institui um mundo canônico de significações, atribuindo uma virtual onipotência a seu magma de significações imaginárias - capazes desde então da exorcização de qualquer interpretação discordante, de todas as irrupções do mundo bruto, das manifestações singulares do sonho e da doença. Nessa conservação, realiza-se de forma sistemática a denegação e o ocultamento da dimensão instituinte da sociedade, a imputação da origem e do fundamento da sociedade instituída e das significações a uma fonte extra-social e a instituição do poder explícito.

Para Castoriadis (2002), há em toda sociedade, necessariamente, o político:

[...] a dimensão explícita, implícita, às vezes inalcançável - que diz respeito ao poder, ou seja, a instância (ou as instâncias) instituída que pode emitir imposições sancionáveis e que deve sempre compreender, explicitamente, pelo menos um poder judiciário e um poder governamental (p. 256).

Esse poder, que se efetiva na interiorização das significações imaginárias sociais pelos indivíduos, e que é também exercido pela coerção, tem como função “[...] restabelecer a ordem, garantir a vida e a operação da sociedade contra todos e contra tudo o que, atual ou potencialmente, a coloca em perigo" (CASTORIADIS, 1992, p. 130). Ainda é esse poder explícito que garante o monopólio das significações legítimas do social-histórico considerado, pois, “[...] para além do monopólio da violência legítima, há o monopólio da palavra legítima; e este, por sua vez, é ordenado pelo monopólio da significação válida" (CASTORIADIS, 1992, p. 132). Encontra-se, portanto, nas significações imaginárias sociais e no processo de sua internalização pela psique - fabricação dos indivíduos sociais - o rochedo para a questão central desta pesquisa: pode o indivíduo deixar de ser só produto de sua psique, de sua história e da instituição que o formou, isso é, tornar-se uma subjetividade reflexiva e deliberante? Como falar de autonomia individual e social, se não se toma como ponto de partida e de chegada o projeto de autonomia?

Para Castoriadis (1992), “[...] a subjetividade, como instância reflexiva e deliberante (como pensamento e vontade), é projeto social-histórico cuja origem (duas vezes repetidas, na 
Grécia e na Europa ocidental, sob modalidades diferentes) é datável e localizável.” (p. 121). Assim, a subjetividade reflexiva deliberante é uma virtualidade, uma possibilidade, e pode ser um projeto e um querer para as sociedades, à jusante da herança grego-ocidental, a qual não está inteiramente presa aos dogmas e nem as significações imaginárias sociais, pois, ela é uma criação social-histórica, na qual o “[...] ser humano pode questionar-se e considerar-se como origem, certamente parcial, da sua história passada, como também querer uma história que está por vir e querer ser seu co-autor" (p. 236).

Nesse sentido, considerando o efetivo exercício de infrapoder que a sociedade mantém sobre a psique no processo de socialização; considerando, também, o exercício do poder explícito e o permanente processo de auto-ocultamento de criação por parte da sociedade, a possibilidade de reflexividade e de vontade própria dos seres humanos é quase que reduzida à zero. Para o autor:

O indivíduo social, nível "socialmente funcional" do ser humano, apresenta
certamente os caracteres de um para si, é fabricado a partir do material psíquico pela
sociedade (via família, a linguagem, a educação, etc.) mas é "separado" das outras
instâncias psíquicas pela barreira do recalque. Mais ou menos co-extensiva ao
"consciente" da primeira tópica freudiana, ele é capaz de "pensamento" nas
estruturas instituídas, e de "volição" - no sentido de ativação pelo consciente dos
mecanismos motores - nas mesmas estruturas. Mas, em regra geral (se
considerarmos toda a extensão da história e das sociedades humanas) ele não está
em condições de questionar essas estruturas, nem por conseguinte de se questionar a
si mesmo. Portanto, não tem reflexividade no sentido preciso e forte do termo - e,
consequentemente, a capacidade de atividade deliberada tal qual foi definida aqui -
característica do que é necessário chamar de subjetividade humana.
(CASTORIADIS, 1992, 235-236).

Assim, falar de autonomia, de reflexividade e de ação deliberada implica a elucidação e a compreensão da criação da realidade social-histórica, em suas dimensões instituinte e instituída, em seus mecanismos de autoconservação e, em especial, em seu processo de socialização ou de fabricação social dos indivíduos, da autonomia e da heteronomia e da possibilidade de interrogação sem limites, seja na filosofia, seja na política. Dessa forma:

A coletividade somente pode existir como instituída. Suas instituições sociais são, a cada vez, a sua criação própria, mas quase sempre, depois de criadas, elas aparecem para a coletividade como dadas (pelos antepassados, pelos deuses, por Deus, pela natureza, pela Razão, pelas leis da história, pelos mecanismos da concorrência, etc.). Tornam-se fixas, rígidas, sagradas. Sempre há, nas instituições, um elemento central, potente e eficaz, de autoperpetuação (e os instrumentos necessários para esse fim) o que chamaríamos, em psicanálise, de repetição. O principal desses instrumentos é, como já disse, a fabricação de indivíduos conformes. [...] É imediatamente evidente que o projeto de uma sociedade autônoma perde todo sentido se não for, ao mesmo tempo, o projeto que visa a fazer surgir indivíduos autônomos e vice-versa (CASTORIADIS, 1992, p. 159). 
Pois, como todo para si, também a sociedade fecha-se em si mesma e esconde sua própria gênese, buscando explicações outras para sua origem, identificando fora de si própria as razões de sua existência. Essa negação de seu poder criador constitui a heteronomia, pela qual os indivíduos localizam fora de si e dos outros a gênese da existência humana.

Para Castoriadis (1992):

\begin{abstract}
A sociedade cria seu mundo, ela o investe de sentido, faz provisão de significação destinada a suprir com antecedência tudo o que aparecer. O magma de significações imaginárias socialmente instituídas absorve potencialmente tudo o que poderia acontecer, em princípio, não pode ser surpreendido ou pego desprevenido. Nisso, evidentemente, o papel da religião - e sua função essencial para a clausura do sentido - sempre foi central (p. 128).
\end{abstract}

Tal fato é também institucionalizado, isto é, a representação de uma origem da instituição, posta fora da sociedade, é imposta aos indivíduos sociais por sua própria sociedade, o que se permite caracterizá-la como sociedade heterônoma.

Assim, o mesmo autor chamou atenção para o fato de que a autoinstituição da sociedade é auto-ocultada e que esta é característica fundamental da heteronomia das sociedades, que se inicia quando os sujeitos nascem e sofrem uma ação da sociedade instituída, personificada na figura da mãe, que se lhes apresenta o mundo, dá nome às coisas, aos objetos, aos valores e às ideias: Nas sociedades heterônomas, isto é, na esmagadora maioria das sociedades que
existiram até agora - quase todas -, encontra-se, institucionalmente estabelecida e
sancionada, a representação de uma origem da instituição da sociedade posta fora da
sociedade: nos deuses, em Deus, nos ancestrais, nas leis da Natureza, nas leis da
Razão, nas leis da História. Em outros termos, encontra-se nessas sociedades a
representação imposta aos indivíduos, de que a instituição da sociedade não depende
deles, que eles não podem tomar a seu cargo a feitura de sua própria lei - pois é isto
o que significa autonomia -, mas que essa lei já está dada por alguém ou algo
distinto deles. Há, portanto, uma auto-ocultação da auto-instituição da sociedade, e
essa é uma parte integrante da heteronomia da sociedade (CASTORIADIS, 1987b,
p. 322).

Isso possibilita interrogar: quem são os indivíduos sociais? Por que admitem passivamente a representação da origem de sua sociedade, posta fora de si mesma? Consequência da fabricação social, o fechamento cognitivo faz com que cada um sempre julgue e escolha não apenas no seio da instituição que o criou, mas com a ajuda da instituição social-histórica particular - a cultura, a tradição - que o formou. Sem isso, ele seria incapaz de julgar e escolher o que quer que fosse. Ressalta-se ainda que "Julgar e escolher, no seu sentido mais radical, foram atitudes criadas na Grécia; é este um dos sentidos da criação grega da política e da filosofia" (CASTORIADIS, 1987b, p. 290). 
Dentre as criações da nossa história, tributária da filosofia greco-ocidental, destacamse "o questionamento, a crítica, o logon didonai, o dar conta e razão, que é a pressuposição ao mesmo tempo da filosofia e da política" (CASTORIADIS, 1992, p. 111).

Herdeira da filosofia greco-ocidental, mas, ao mesmo tempo, denegando a descoberta da iniciativa humana na criação da sociedade, da efetivação da filosofia como interrogação ilimitada do mundo instituído e da política como auto-instituição efetiva da sociedade, nossa tradição instala-se na mais plena heteronomia.

Somente a ruptura dessa heteronomia permite a verdadeira singularização do indivíduo - na qual a imaginação radical da psique pode, ao mesmo tempo, achar ou criar os meios sociais de uma expressão pública original e contribuir, nomeadamente, para autoalteração do mundo social, criando novos eidos que poderão alterar a sociedade e os indivíduos reciprocamente.

Mas, como pensar a construção da autonomia individual e social, numa sociedade que denega a filosofia e a política, na acepção grega?

Mais ainda, pensar, em nossa sociedade, um conceito de educação só será possível se forem observadas duas exigências: a socialização da psique para a necessária internalização do mundo instituído, mas cujos resultados são quase sempre a reprodução da sociedade heterônoma e fabricação de indivíduos heterônomos, que desconhecem e alienam o poder criador em si mesmo; e uma socialização da psique que comporte uma inibição mínima de sua imaginação radical e o desenvolvimento máximo de sua reflexividade. Nesse sentido, são pertinentes as colocações de Castoriadis (1992):

\footnotetext{
A criação pelos gregos da política e da filosofia é a primeira emergência histórica do projeto de autonomia coletiva e individual. Se quisermos ser livres, devemos fazer nosso nomos. Se quisermos ser livres, ninguém deve poder dizer-nos o que devemos pensar. (p. 138).
}

Dessa forma, a filosofia e a política colocam-se como atividades a serem instituídas por meio da educação - pois ambas são interrogações sobre o instituído. Mas, se toda e qualquer sociedade é uma construção, uma criação de um mundo, de seu próprio mundo, que existe e só pode existir no fechamento cognitivo, isto é, na sacralização de suas regras, representações e significações imaginárias, como pensar a possibilidade de se realizar o desafio da filosofia e da política-democracia, se elas parecem ser um perigo mortal, um ataque ao sistema de interpretação, à identidade e à própria sociedade?

Assim, de acordo com Castoriadis (1992), a "filosofia, que cria a subjetividade com capacidade de refletir, é o projeto de romper a clausura a nível de pensamento" (p. 247). Esse 
projeto não se realiza, no entanto, sem a política, que se refere às deliberações e às ações efetivamente realizadas.

Pensa-se a prática educativa com a finalidade de formar sujeitos autônomos, como atividade que pode contribuir, ainda que não de forma isolada, para o processo de individuação dos sujeitos, com vistas a desenvolver ao máximo sua reflexividade, assim como, a construção de novas significações sociais, capazes de ultrapassar e superar o internalizado no processo de socialização. Nesse projeto, é mister que o pedagogo/educador tenha também que se autoalterar, ampliando ao máximo sua reflexividade em relação à sociedade em que está inserido, à educação, escola e suas ideias e valores, enfim, a tudo o que nele está internalizado como resultado da ação do infrapoder social.

Assim, será não somente em razão, mas também em consequencia de sua prática educativa que o pedagogo poderá vir a construir uma atitude de interrogação sobre si, sobre sua existência, sobre seu mundo e sobre os outros, desenvolvendo interesse ou paixão por aquilo que escolheu como prática de trabalho, como sua contribuição à sociedade.

Dessa forma, será pela efetivação da capacidade de iniciativa e pela reflexão que o indivíduo fundamentará, teórica e criticamente, seus conhecimentos e suas práticas, buscando conhecer/compreender os fatos, as coisas, as situações, as ideias, os comportamentos e os valores. Para isso, deverá investigar, conhecer, compreender, antes de aceitá-los, ou escolhêlos, ou deliberar sobre eles, e buscar responder, concretamente, se aquilo que ele pensa que sabe sobre coisas, fatos, situações, ideias, comportamentos, valores e sobre si mesmo, ele realmente sabe. Deverá, ainda, buscar substituir os estereótipos, os preconceitos, os prejuízos, o conhecimento de senso comum e as crenças por conhecimentos mais consistentes e coerentes. Na reflexão filosófica, o indivíduo também poderá buscar conhecer-se, construindo, de forma explícita e lúcida, os motivos, os sentidos e as finalidades dos seus atos. É essa a base da política, que Castoriadis (1992) definiu como

\footnotetext{
[...] a atividade que visa à transformação das instituições da sociedade, para tornálas conformes à norma da autonomia da coletividade (isto é, tais quais permitem a autonstituição e autogoverno explícitos, refletidos e deliberados, desta mesma coletividade" (p. 71-72).
}

A política, tal como os gregos a conceberam, “[...] foi o questionamento explícito da instituição estabelecida da sociedade" (p. 135).

De forma mais direta, pode-se definir a política, em sua acepção original, como a atividade de participação dos indivíduos nas deliberaçoes que concernem à vida comum; mas 
também, de certa forma, como a instituição da cultura que não somente possibilita, mas valoriza e igualmente enseja a paixão pelas questões comuns.

No caso da sociedade brasileira, que se caracteriza, segundo Chauí (1994a), por relações sociais e políticas hierárquicas, fundadas em contatos pessoais; por relações sociais e econômicas extremamente desiguais, decorrentes da concentração de renda; e por relações sociais desiguais perante à lei, inexistem a igualdade formal-jurídica e a igualdade social real, a liberdade e a responsabilidade, o respeito às instituições sociais e políticas, às condições para a cidadania e à democracia.

Além disso, nas democracias representativas modernas, o fato da representação já é, em si, uma transferência do poder decisório, que se caracteriza ausência de controle sobre a procuração que se concede ao representante. Nela se denega a igualdade, a liberdade, a responsabilidade, o respeito às instituições sociais e políticas e à própria lei.

Assim, o que se observa na sociedade brasileira - que, como tantas outras nações modernas, vivem uma democracia representativa - é o exercício do monopólio do poder explícito; e não da atividade política na acepção grega, que comporta não só a deliberação comum, como o questionamento pela qual se interrogam as representações e normas da tribo, e até a própria noção de verdade. Essa dicotomia entre a dimensão do poder explícito - o político e a política - foi rompida na Grécia Antiga, na medida em que

a) Uma parte do poder instituinte foi explicitado e formalizado (concretamente, a que se relaciona com a legislação no sentido próprio, público - "constitucional" -, bem como privado);

b) instituições foram criadas para tornar a parte explícita do poder (inclusive o "poder político", no sentido definido anteriormente) participável. Donde a igual participação de todos os membros do corpo político na determinação do nomos, da diké e do télos - da legislação, da jurisdição, do governo (CASTORIADIS, 1992, p. 144).

Isso implicou a absorção do político - poder explícito - pela política, isto é, a estrutura e o exercício do poder explícito tornaram-se objeto de deliberação e decisões coletivas do corpo político, e a discussão da instituição efetivou-se de forma radical e ilimitada, pois " [...] a política é projeto de autonomia: atividade coletiva refletida e lúcida visando à instituição global da sociedade como tal” (CASTORIADIS, 1992, p. 145).

A política constitui, portanto, uma atividade coletiva, refletida e deliberada, cujo objeto e finalidade são a instituição da sociedade - ao contrário do poder explícito, cuja finalidade é a mera preservação do social-histórico.

Assim, liberdade e autonomia são significações sociais que remetem à questão da política, e não do político, e à nossa herança grega, uma vez que 
[...] a criação pelos gregos da política e da filosofia é a primeira emergência histórica do projeto de autonomia coletiva e individual. Se quisermos ser livres devemos fazer nosso nomos. Se quisermos ser livres, ninguém deve poder dizer-nos o que devemos pensar (CASTORIADIS, 1992, p. 138).

Para Martins (2002), “[...] na visão de Castoriadis, a autonomia é um empreendimento da humanidade e um programa de reflexão filosófica sobre o indivíduo há 27 séculos" (p. 218). Segundo o filósofo, "Se à autonomia, à legislação ou à regulação por si mesmo, opomos a heteronomia, a legislação ou a regulação pelo outro, a autonomia é minha lei, oposta à regulação pelo inconsciente que é uma outra lei, a lei de outro que não eu" (CASTORIADIS, 1982, p. 123-124).

Ao definir a história como criação, como “[...] o domínio em que o ser humano cria formas ontológicas - sendo elas próprias, a história e a sociedade [...]”, o autor rompe com a exigência de determinidade, presente na filosofia ao longo de sua história. Usando a especificidade das significações imaginárias para definir a individualidade de um período histórico, ele tece, no que diz respeito à modernidade, a trama da imbricação de duas significações imaginárias sociais - a autonomia e a expansão ilimitada do "domínio racional", e propõe a seguinte periodização: a emergência (constituição) do Ocidente; a época crítica (moderna); e a retração no conformismo (CASTORIADIS, 1992, p. 18-19 e 111).

A constituição da civilização ocidente, que compreende o século XII ao começo do século XVIII, caracteriza-se pela autoconstituição da protoburguesia, pela construção e pelo crescimento das cidades novas, pela reivindicação de uma espécie de autonomia política, pela redescoberta e recepção do direito romano, da obra de Aristóteles e do conjunto da herança grega. De acordo com Castoriadis (1992), esse é o período em que, de "[...] forma ainda embrionária, e mesmo devendo constantemente fechar compromissos com os poderes estabelecidos (Igreja e monarquia), o projeto de autonomia social e individual ressurge depois de um eclipse de 15 séculos" (p. 19).

O segundo período, a época crítica (“moderna”), abrange o século XVIII até as guerras mundiais do século, 1750 a 1950, e caracteriza-se pela contaminação e pelo emaranhamento das significações sociais: de autonomia e expansão ilimitada do "domínio racional", encarnada pelo capitalismo.

Segundo Castoriadis (1992):

O projeto de autonomia radicaliza-se no campo social e político, assim como no intelectual. As formas políticas instituídas são questionadas; formas novas, implicando rupturas radicais com o passado, são criadas. À medida que o movimento se desenvolve, a contestação invade outros domínios, além do campo estritamente político: as formas de propriedade, a organização da economia, a família, a situação das mulheres e as relações entre os sexos, a educação e o estatuto 
dos jovens. Pela primeira vez na era cristã, a filosofia rompe definitivamente com a teologia [...] Vê-se ocorrer enorme aceleração do trabalho e uma expansão dos campos da ciência racional. [...] Ao mesmo tempo, cria-se nova realidade socialeconômica - em si mesma, um "fato social total" - o capitalismo. (p. 19-20).

Esse período de contaminação mútua, de emaranhamento, de oposição e tensão entre as significações imaginárias, autonomia social e individual versus expansão ilimitada do "domínio racional”, tem sua visibilidade na manifestação e na persistência do conflito social e ideológico, força motriz do desenvolvimento da sociedade ocidental.

Ressalta-se todavia que, na condição de fato social total, o capitalismo e a significação imaginária da expansão ilimitada do "domínio racional" que ele encarna penetra na totalidade da vida social, no Estado, nas forças armadas, na educação etc., o que leva a uma nova concepção de razão, processo aberto de crítica e elucidação, agora transformada em computação mecânica e uniformizante.

O terceiro período, a retração no conformismo, inicia-se em 1950, marcado pelas “duas guerras mundiais, a emergência do totalitarismo, a derrocada do movimento operário [...] o declínio da mitologia do progresso [...]" e, é caracterizado pela "evanescência do conflito social, político e ideológico" (CASTORIADIS, 1992, p. 22).

O homem contemporâneo típico age como se ele suportasse a sociedade à qual, de
resto (sob a forma do Estado ou de outrem), ele está sempre pronto a imputar todos
os seus males e a apresentar - ao mesmo tempo - demandas de assistência ou de
"soluções a seus problemas". Ele já não alimenta projeto relativo à sociedade - nem
o de sua transformação, nem mesmo o de sua conservação/reprodução. Ele já não
aceita as relações sociais nas quais se sente preso e que apenas reproduz porque não
pode deixar de fazê-lo (CASTORIADIS, 2002, p. 22).

O que aconteceu para que o homem contemporâneo se colocasse numa postura de conformismo generalizado e o que é necessário para que tal quadro se reverta? A hipótese com que se trabalha é que a resposta a estas duas interrogações, se existe e tanto quanto existe, se traduz em prática social - e, antes de qualquer outra, em educação.

O conformismo generalizado dos homens contemporâneos, que Castoriadis denuncia em seus últimos textos, é fabricado por uma sociedade em que são passivos espectadoresconsumidores, dispensados de pensar e de refletir - o que implica que devem ter, como única competência, a flexibilidade e a obediência para serem governados, receberem o pão - bolsaescola - e aplaudirem o espetáculo que é a sociedade brasileira.

A ruptura do quadro de conformismo generalizado só se efetivará se, para além da demagogia e do pensamento fraco dos políticos brasileiros, a educação tornar-se uma prática social que tenha por finalidade ajudar os homens a tornarem-se autônomos - o que, para Aristóteles significa torná-los capazes de governar e de serem governados. 
Para Faria (2000), esse período de conformismo culmina com a criação do cidadão privatizado:

Indiferente à política, mergulhado num universo estritamente pessoal, esse cidadão, do ponto de vista de Castoriadis, caiu num niilismo cansado: submisso ao mercado e às ilusões do consumismo, manifesta traços de uma sociedade que não é democrática, já que nela não há luta por mais liberdade (p. 4).

Mas, até que ponto as significações sociais de liberdade e autonomia estão presentes e vivas, constituindo-se ainda um querer da sociedade? Até que ponto essas significações não foram esvaziadas do seu verdadeiro conteúdo e travestidas no desejo e no gozo? Ou constituem-se elas ainda em vetores que mobilizam o coletivo?

A denegação da dimensão instituinte da sociedade, a recuperação do imaginário instituído, condiz com a criação de indivíduos absolutamente conformes, que vivem e se pensam, na repetição (aliás, ainda que possam fazer, fazem muito pouco), cuja imaginação radical é reprimida o mais possível; indivíduos que quase não são verdadeiramente individuados (CASTORIADIS, 1992, p. 139).

A autonomia significa o dar-se a si próprio suas leis - isso é, numa sociedade autônoma os indivíduos devem participar da proposição, da discussão, da deliberação e, em seguida, da manutenção ou não das normas comuns. Assim, a efetivação, sempre parcial, do projeto de autonomia pressupõe que se estabeleça, no plano social, um contínuo questionamento: nossas leis são boas? São justas? Que leis devem ser feitas? E, no plano individual: o que eu penso é certo? O que penso dever fazer, ou pensar, de modo a manter minha coerência? Nesse sentido, pode-se falar de autonomia e liberdade, pois:

A autonomia surge, como germe, assim que a interrogação explícita e ilimitada se manifesta, incidindo não sobre "fatos" mas sobre as significações imaginárias sociais e seu fundamento possível. Momento de criação, que inaugura não só outro tipo de sociedade, mas também outro tipo de indivíduos. Eu falo exatamente de germe, pois a autonomia, tanto social como individual, é um projeto. $\mathrm{O}$ surgimento da interrogação ilimitada cria um eidos histórico novo, - a reflexividade no sentido pleno, ou auto-reflexividade, como o indivíduo que a encarna e as instituições onde ela se instrumenta. (CASTORIADIS, 1992, p. 139).

Pensar e querer autonomia é um projeto individual e social, pois não se pode ser autônomo sozinho e imerso num social-histórico heterônomo. Pensar e querer autonomia implica a criação de um novo tipo de homem e de sociedade, e a criação do que Castoriadis denominou a "subjetividade reflexiva e deliberante". Pensar e querer autonomia pressupõe a:

[...] reabsorção do político como poder explícito, na política, atividade lúcida e deliberada tendo por objeto a instituição explícita da sociedade (por conseguinte também, de todo poder explícito) e sua operação como nomos, diké e telos legislação, jurisdição, governo -, tendo em vista fins comuns e obras públicas que a sociedade se propôs deliberadamente (CASTORIADIS, 1992, p. 149). 
Uma sociedade livre e autônoma é aquela que se dá, efetiva e reflexivamente, suas próprias leis, aquela cujos cidadãos nela se reconhecem e participam tanto da formação das leis como do exercício do poder. Assim:

\begin{abstract}
Uma sociedade autônoma, uma sociedade verdadeiramente democrática, é uma sociedade que questiona qualquer sentido pré-dado, e na qual, por isso mesmo, está liberada a criação de novas significações. E, numa tal sociedade, cada indivíduo é livre para criar para a sua vida o sentido que quiser (e puder). Mas seria absurdo pensar que ele pode fazer isso fora de todo contexto e de todo condicionamento sócio-histórico [...] O indivíduo individuado cria um sentido para sua vida ao participar das significações criadas por sua sociedade, ao participar de sua criação, seja como "autor", seja como "receptor" (público) dessas significações. E sempre insisti sobre o fato de que a verdadeira "recepção" de uma obra nova é tão criadora quanto a sua criação (CASTORIADIS, 2002, p. 73).
\end{abstract}

Mas, daí surgem as questões: qual é a capacidade e o desejo das pessoas de se organizarem coletivamente, participando, ativa e responsavelmente, da direção de suas atividades e do enfrentamento da instituição global da sociedade? Até que ponto a vida social tal como a conhecemos está pronta a aceitar a incerteza, o questionamento, com tudo o que isso comporta de risco, de angústia? Será que de fato, na sociedade contemporânea, se quer e se aceita uma grande transformação no modo de ser, viver e pensar, constituindo-se novo homem e nova sociedade? A essas questões, a resposta não pode ser individual, mas coletiva. Mas até que ponto o social-histórico brasileiro se apresenta em condições de respondê-las?

Acredita-se que qualquer resposta positiva para essas interrogações depende de se concretizar a educação como formação geral. É bem verdade que historicamente, a educação vem constituindo um espaço instituído de fabricação social de indivíduos conformes ao status quo, subordinados ao instituído, incapazes de iniciativa e heterônomos, adaptados aos processos de trabalho, à exigências de mercado. Mas a educação pode, se houver vontade política individual e social, transformar-se em uma prática institucional que atue na formação de indivíduos autônomos, na acepção de Aristóteles; ela pode vir a constituir-se na formação de seres prontos tanto para o governar quanto para serem governados. A educação pode, enfim, fazer-se formação de indivíduos apaixonados pelas questões comuns.

Para Castoriadis (1987b):

Apenas a educação (paidéia) dos cidadãos enquanto tais pode dotar o "espaço público" de um autêntico e verdadeiro conteúdo [...]. Ela consiste, antes de mais nada e acima de tudo, na tomada de consciência, pelas pessoas, do fato de que a polis é também cada uma delas, e de que o destino da polis depende também do que elas pensam, fazem e decidem: em outras palavras: a educação é participação na vida política (p. 302).

A prática educativa efetiva-se na participação política. Ressalta-se que no berço da democracia, a antiga Grécia, não existia instituição educacional específica, e muito menos 
democracia representativa: a formação dos cidadãos se fazia pela própria polis. Todavia, podemos tomar como gérmen a ideia de que a polis é o que pensam, fazem e decidem os cidadãos, e de que "[...] o ser humano será o que farão dele os nomoi da polis [...]. Eles sabem, portanto, que não há ser humano que valha sem uma polis que valha, que seja regida pelo nomos apropriado" (CASTORIADIS, 1992, p. 137).

Assim, mesmo que se tenha instituído a escola com a função precípua de educar, não se pode desconsiderar que ela é atravessada pelas significações imaginárias sociais vigentes. Assim, se na modernidade criou-se a escola, esta não realiza sua função educativa descolada dos condicionantes sociais e históricos. Embora componha com outros agentes - a família, classes de idade, ritos, costumes, leis etc. - a escola, sua criação e finalidade, pressupõe uma atividade intencionalizada e sistematizada.

Pensar a escola como espaço de formação pressupõe discutir a formação de professores que se concretizava na antiga Escola Normal, nos cursos de Pedagogia e nos cursos de licenciatura diversos. Nesta pesquisa, privilegia-se o curso de Pedagogia, para nele discutir o papel da Filosofia da Educação. 


\section{PARA COMPREENDER A FILOSOFIA DA EDUCAÇÃO}

A educação é uma relação social fundamental, uma atividade prático-poiética, um enigma, em que, muito embora definidos os envolvidos - professores e alunos - e os meios conhecimentos na forma de matérias específicas, sob as determinações das normas legais nunca se pode nunca prever o resultado do processo, já que tanto professores como alunos são sujeitos de liberdade.

A educação, que, nas instituições escolares, vem historicamente privilegiando a dimensão cognitiva, deve compreender os discentes em suas dimensões complementares e indissociáveis - a representação, a afetividade e a intencionalidade.

Pensar o conceito de educação, pensar em sua finalidade, pressupõe pensar na sociedade em que se vive, na que se quer viver e na que se quer construir.

Partes integrantes da estrutura social e resultado da ação dos homens, as instituições estão sempre em estado de "tornar-se". Elas não são entidades determinadas e fixas - pelo contrário, constituem afloramentos do processo de construção/fabricação social. Nesse sentido, sua identidade, seus processos de relações e suas funções resultam de atos passados da construção social que determinam se elas visam à manutenção do status quo ou se elas visam à alteração da ordem instituída e consolidada.

Assim, ao discutir a construção da disciplina Filosofia da Educação na formação dos educadores no Brasil, deve-se fazê-lo a partir da deliberação dos homens, com uma finalidade explícita ou não.

Para Tomazetti (2000a):

A construção disciplinar da filosofia da educação, no Brasil, pode ser compreendida à luz de três processos simultâneos, os mesmo que Antônio Nóvoa descreveu em relação ao nascimento da disciplina História da Educação em Portugal e grande parte da Europa. Tais processos seriam: a estatização do ensino, a institucionalização da formação de professores e a cientifização da pedagogia (p. 128).

Partindo da concepção de Nóvoa, pensa-se que a disciplina Filosofia da Educação pode ser elucidada à luz de processos como: a institucionalização do monopólio legislativo do Estado sobre a educação; a institucionalização da formação de professores, com a criação da Faculdade de Educação, em 1931 e do Curso de Pedagogia, em 1939; e a tentativa de adoção de uma perspectiva cientista na Educação. 


\subsection{A institucionalização do monopólio legislativo do Estado sobre a educação}

Polis andra didaskei (a cidade que educa o homem).

Simônides

Para Castoriadis (1992), o Estado é uma criação da tradição ocidental moderna, especializada em poder, "[...] uma instância separada da coletividade", "instituída como aparelho de Estado, o que implica uma "burocracia" separada, civil, clerical ou militar, muito embora rudimentar, isto é, uma organização hierárquica com delimitação das regiões de competência" (p. 133). É essa instância que, instituída com a Proclamação da República em 1889 sem a participação do povo, caracterizará a emergência da República brasileira.

Ora, a ideia de Estado, como analisou Castoriadis, define a realidade de especialização do poder, feito monopólio de representantes, e marca a oposição entre o povo e esses representantes, tanto quanto os experts e entre a comunidade e o Estado.

A institucionalização da República brasileira, Decreto 01, de 15/11/1889, “[...] foi consequência de um golpe militar ao qual - disse Aristides Lobo - o povo teria assistido "bestializado" como se estivesse vendo uma parada militar" (CURY, 2001, p. 25, ao citar José Murilo de Carvalho, 1990).

Assim, à ideia de um processo histórico instituinte, de mobilização do social-histórico para a mudança das instituições e para a autoinstituição explícita da República brasileira, contrapõe-se outra realidade, conforme o texto abaixo:

\footnotetext{
Senhores representantes da Armada da terra e do mar. Nós temos a honra de vos informar que, após a gloriosa e nobre resolução pela qual ipso facto a monarquia foi deposta, o povo, através de seus organismos espontâneos e através de seu representante legal nesta cidade, reuniu-se no palácio do Conselho Municipal e, na forma da lei, proclamou como nova forma da lei, proclamou como nova forma de governo, no Brasil, a República. Os signatários esperam que a patriótica classe militar sancione a iniciativa popular decretando imediatamente a nova forma republica de Governo Nacional (D'ARAÚJO, 1893, p. 134-135 apud CURY, 2001, p. 43).
}

Vê-se, então, que o povo participou da institucionalização da República apenas como mero espectador, embora em seu nome tenham sido conclamados os militares, responsáveis pelo novo regime. Assim, a alteração do regime de Império para República, sem a efetiva participação do povo brasileiro, nas instâncias de decisão das esferas econômica e política, resultou de uma alteração do regime pelos militares, sem alteração ou criação de instâncias deliberativas democráticas. 
Em um regime democrático, segundo Castoriadis (1987b, p. 295-196), “[...] o corpo soberano é a totalidade das pessoas envolvidas e, sempre que se torna inevitável uma delegação, os delegados não são simplesmente eleitos, mas podem ter, a qualquer momento, seu mandato revogado". Proclamada a República brasileira à revelia do povo, poucas mudanças ocorreram - principalmente no que concerne à própria política. Mantiveram-se as mesmas instituições e, dentre elas, a lógica da democracia de "representação", que impedia a participação dos brasileiros no novo governo.

As decisões relativas à legislação e, em especial, à nova Constituição ficaram a cargo dos representantes do Congresso Nacional Constituinte, instalado em 1890.

De acordo com Castoriadis (1987b):

\begin{abstract}
A idéia dominante de que existem experts em política, vale dizer, especialistas do universal e técnicos da totalidade, menospreza a idéia mesma de democracia: o poder dos políticos se justifica pela expertise que só eles possuiriam - e o povo, imperito por definição, é chamado periodicamente a dar a sua opinião sobre esses experts. Tendo em conta a vacuidade da noção de uma especialização no universal, esta idéia encerra igualmente os germens do divórcio crescente entre a aptidão a alçar-se ao topo do poder e aptidão a governar - divórcio cada vez mais flagrante nas sociedades ocidentais (p. 297-298).
\end{abstract}

Dessa forma, a República brasileira inicia-se com os políticos, os representantes e o Estado contra o povo - os poucos "chamados" a opinar o farão apenas pelo instrumento eleitoral.

No que concerne à educação, o processo de institucionalização do monopólio do Estado reafirma-se, na República brasileira, pelo Decreto 346, de 19/03/1890, que cria o Ministério da Instrução Pública, Correios e Telégrafos, afirmando a iniciativa do Governo da República nascente, na área educacional, bem com pelo Decreto 08, de 20/11/1889, no qual são fixadas, provisoriamente, as atribuições dos governos estaduais: “[...] já no parágrafo 2. do art. $2^{\circ}$, como competência dos Estados, "providenciar sobre a instrução pública e os estabelecimentos próprios e promovê-la em todos os seus graus."” (CURY, 2001, p. 55). O Decreto 06, de 19/11/1889, que define o cidadão brasileiro e seus direitos políticos, toma como critério a escolarização do votante, excluindo o analfabeto do direito ao voto.

Condiciona-se, pois, a cidadania à escolarização, fazendo desta uma condição sine qua non, como é explicitado no Decreto 200-A, de 08/02/90 - que, em seus artigos. $4 .^{\circ}$ e $5 .^{\circ}$, define quem é o eleitor: "Se a cidadania brasileira era um direito civil nacional, daí não se segue que ela se equalizasse em termos de direito político do eleitor" (CURY, 2001, p. 72). Segundo ainda esse autor,

[...] a instrução era vista como um meio de transformar o súdito em cidadão político, e ela teria também o papel complementar de possibilitar ao cidadão 
entendimento das novas tarefas do Estado, no campo do casamento civil, da secularização dos cemitérios, da laicização e suas decorrências" (p. 101).

Mas “[...] restará aos excluídos da "polis" ser a âncora desta "modernização conservadora" através da "ordem" como prática social e como escopo de uma socialização "pedagógica”, que incluía a "questão social" nos quadros do Código Penal” (p. 88). Todavia, o projeto republicano de escolarização não se concretizou, pois não se fazia acompanhar do princípio da obrigatoriedade.

A contradição inerente à organização de uma sociedade heterônoma, na qual se exige, de um lado, maior passividade e, de outro, maior participação, fez-se presente na institucionalização da República brasileira. Embora tenha sido considerada um dos pilares para transformação do súdito em cidadão, a educação não recebeu a atenção devida por parte da República, que não a tornou obrigatória. Pelo contrário, ao definir os direitos do cidadão, utilizou-a como critério para exclusão dos analfabetos da sociedade política brasileira e tornou-os, responsáveis pelo seu próprio desejo, acesso e permanência na escola que existia alhures.

É nesse sentido que o direito, como manifestação ideológica, tem uma dupla função. "De um lado, forma ideológica adequada da realidade para a classe dominante, exprimindo os seus interesses históricos e sociais; e de outro, como instrumento de mistificação ideológica para o resto da sociedade". Assim, as expressões do "[...] Direito Constitucional, tais como "direitos civis", "igualdade social", "liberdade de expressão", "soberania popular", "cidadania", etc. são vazias de significado e exercem, de fato, a função de escamotear a verdadeira realidade, na qual todos esses direitos não existem" (MACIEL, 1987, p. 48-49).

Ressalte-se que a Constituição de 1891, Título IV - Dos cidadãos brasileiros - Seção I - Das qualidades do cidadão brasileiro - Artigo 70, define como eleitores os maiores de 21 anos alistados na forma da lei, excluindo, tanto nas eleições federais como nas estaduais, os mendigos e os analfabetos. Ora, na Seção II - Declaração de Direitos da Constituição, no Artigo 72, assegura-se a brasileiros e estrangeiros, residentes no país, a inviolabilidade dos direitos concernentes à liberdade, à segurança e à propriedade, nos termos de que todos são iguais perante a lei, pois a República não admite privilégios de nascimento. Nesse sentido, indaga-se: todos são iguais perante a lei? As condições sociais e históricas do nascimento não implicam privilégios? Onde se dá, então, a construção da desigualdade social? Como delimitar o conjunto dos cidadãos eleitores, ao excluir os analfabetos e os mendigos?

Para Maciel (1987): 
[...] os homens não são iguais naturalmente. Eles são desiguais. A "lei” é que os deve equalizar, se o objetivo for o advento de uma sociedade igualitária. E isto significa igual participação na cultura, no saber e no poder, igual participação do homem, da mulher, dos jovens, das minorias étnicas, etc. Essa igualdade não natural, é principalmente, igualdade política. A dimensão política não pode portanto ser secundária. Ela, afinal, coloca os rumos, os projetos históricos para onde os homens devem se dirigir." (p. 83).

Ressalta, ainda, a autora que "[...] os interesses e aptidões são em grande parte forjados pela situação social e econômica de cada um". Assim, na institucionalização da República brasileira, a sociedade, já dividida em classes sociais, não se preocupou com a igualdade de oportunidades para todos. Tomou do que já estava instituído e, politicamente, nada criou para que o povo participasse da construção da nova sociedade e tivesse acesso ao que lhe estava negado pela condição de nascimento.

É elucidativa a comparação, feita por Castoriadis (apud MACIEL, 1987), entre a proposta do Conselho e a do Parlamento ou Congresso Nacional ou Assembleia:

O Conselho não é uma instituição "miraculosa". Ele não pode ser a expressão dos trabalhadores se os trabalhadores não se decidirem exprimir-se através dele. Mas é uma forma de organização adequada: toda a sua estrutura é organizada de forma a permitir que esta vontade de expressão apareça, se existir. O Parlamento ao contrário, quer se chame "Assembléia Nacional" (...) é, por definição, um tipo de instituição que não poderia ser socialista: ele se baseia na separação radical entre a massa "que é consultada" de vem em quando, e aqueles que, considerados "representantes", permanecem incontroláveis e inamovíveis. O conselho é feito para representar os trabalhadores, e pode deixar de exercer esta função: o Parlamento é feito para não representar as massas, e não deixa jamais de exercer esta função (p. 75).

Para Bellochio et al. (2004):

Com relação à estatização do ensino, podemos afirmar que o Estado brasileiro foi gradativamente assumindo sua função de educador sustentado pelos ideais republicanos. Embora, já na Primeira República, fossem manifestadas preocupações com o elevado número de analfabetos, não houve, no entanto, uma forte demanda por educação, desobrigando o Estado da construção de um sistema nacional de ensino. Somente a partir dos anos 20 do século XX, com a emergência de uma tardia revolução industrial e do reordenamento político e cultural da sociedade brasileira, é que surgiram significativas demandas por uma educação pública, gratuita e universal, que exigiriam do Estado a responsabilidade com a educação nacional, fato que já havia ocorrido em países da Europa no final do século XIX. A escola e o ensino passaram, então, a ser compreendidos pelos parâmetros dos ideais democráticos da Educação Nova que se disseminavam pelo país. Porém, importa ressaltar que nesse novo contexto brasileiro, a escola e o ensino foram considerados elementos potencializadores do desenvolvimento do país (p. 2-3).

Assim, durante a primeira República, diversas reformas educacionais foram instituídas. A primeira, a de Benjamim Constant (1890), estabeleceu o ensino público leigo, gratuito e obrigatório, mas não logrou concretização, seja pelas condições de ofertas de escolas, seja porque a maioria das escolas existentes pertencia a instituições religiosas. 
Segundo Pechula (2001), a Reforma Epitácio Pessoa (1901) “[...] desvinculou a oficialização do ensino ao Estado e equiparou os ensino privado e público das escolas secundárias e superiores”; a Reforma Rivadária Correa (1911) “[...] reforçou a desoficialização do ensino, concedendo plena e total liberdade às escolas tanto de ensino e didática como administrativa"; a Reforma Carlos Maximiliano (1915) “[...] reoficializou o ensino e dificultou o ingresso ao curso superior com a criação dos exames vestibulares e ainda estabeleceu o diploma do secundário como condição para a realização destes exames"; e a Reforma Rocha Vaz (1925) "[...] retirou a autonomia didática e administrativa das escolas e centralizou novamente a organização do ensino [...] Determinou ainda os currículos das escolas superiores e impôs aos vestibulares um caráter de aprovação classificatória” (p. 23-24).

Na segunda República, a institucionalização do ensino superior, especificadamente no caso da formação de pedagogos no Brasil, remonta à década de 30 , com a criação do Ministério da Educação e Saúde Pública, em 1930, e com um conjunto de atos legislativos do Ministro Francisco Campos. Dentre eles, destacam-se o Decreto n. ${ }^{\circ} 19.850$, de 11 de abril de 1931, que cria o Conselho Nacional de Educação; o Decreto n. ${ }^{\circ} 19.851$, de 11 de abril de 1931, que dispõe a organização do ensino superior no Brasil e adota o regime universitário; e o Decreto n. ${ }^{\circ} 19.852$, de 11 de abril de 1931, que determina a organização da Universidade do Rio de Janeiro.

Discutir o ensino no Brasil traz à tona o debate público versus privado, mas também evidencia a ausência de um projeto nacional de educação, uma vez que, até o Governo Provisório, não existia uma sistema de ensino nacional organizado no país. Existiam, sim, atuações, sobretudo monopólios do ensino sob grupos de caráter privado, incluindo os confessionais, que determinavam princípios e valores da educação e ações regionais e parciais no nível dos estados. Até 1930, as reformas procedidas pelo poder central limitaram-se, quase exclusivamente, ao Distrito Federal, que as apresentava como modelo para os estados, que não tinham obrigação de adotá-las.

É no contexto do Governo provisório que se efetiva a Reforma Francisco Campos, Ministro da Educação e Saúde Pública, que, pela primeira vez, “[...] atingia profundamente a estrutura do ensino e, o que é importante, era pela primeira vez imposta a todo o território nacional. Era, pois, o início de uma ação mais objetiva do Estado em relação à educação" (ROMANELLI, 1989, p. 131). Inicia-se, neste momento, a institucionalização do monopólio da educação pelo Estado, no que concerne à legislação educacional, mas continuam vigentes, e cada vez mais efetivas, a presença e a participação de grupos privados, inclusas os confessionais, no oferecimento da educação em todos os níveis. 
Segundo ainda a autora, o ensino superior no Brasil inicia-se com a família real portuguesa no Brasil (1808 a 1821), mas a criação das universidades não se realiza de forma orgânica. Pelo contrário, elas se constituíam da agregação de escolas superiores. Têm-se, assim, as Universidades do Rio de Janeiro - Decreto n. ${ }^{\circ}$ 14.343, de 1920, do Paraná - Lei Estadual n 11.530, de 1915, de Minas Gerais. Somente após o Decreto n. ${ }^{\circ} 19.851$, de 11 de abril de 1931, que se instituiu o regime universitário, constituído no Estatuto das Universidades Brasileiras, que se cria a Universidade de São Paulo, em 1934, a primeira a possuir uma Faculdade de Filosofia, Ciências e Letras, cujos objetivos eram a formação de professores para o magistério secundário e a realização de altos estudos desinteressados e da pesquisa.

Todavia, há que se ressaltar que em 1931, o Ministro da Educação Francisco Campos, ao organizar a Universidade Brasileira - Decretos n. ${ }^{\text {os. }} 19.850,19.851$ e 19.852 , de 11 de abril de 1931, criava uma nova entidade, a Faculdade de Educação. Pelo Artigo 5. ${ }^{\circ}$, do Decreto n. ${ }^{\circ}$ 19.851, para constituir uma universidade, era obrigatória a constituição de, pelo menos, três dos seguintes cursos: Direito, Medicina, Engenharia e Educação.

O Decreto n. ${ }^{\circ}$ 19.852, que dispunha a organização da Universidade do Rio de Janeiro, previa:

\begin{abstract}
Uma Faculdade de Educação, Ciências e Letras para ministrar cursos abrangendo as diversas disciplinas do nível superior, tendo como finalidade melhorar a cultura nacional, no domínio das ciências teóricas, promover pesquisas práticas e originais, proporcionar a necessária formação especializada aos professores e contribuir na organização e aperfeiçoamento do ensino técnico e científico, visando atender ao interesse das diferentes atividades do País.
\end{abstract}

No Rio de Janeiro, cria-se, em 1935, a Universidade do Distrito Federal, por iniciativa de Anísio Teixeira, caracterizada por não possuir as três faculdades tradicionais e ter uma Faculdade de Educação, na qual situava o Instituto de Educação, à qual se incorpora a Escola de Professores com o nome de Escola de Educação, a primeira de nível universitário no Brasil. Para Anísio Teixeira (1969):

[...] apenas de busca do conhecimento pelo conhecimento. Neste aspecto, é que ela se distingue das escolas acadêmicas por campo de conhecimento, cujo objetivo é a busca desinteressada do saber. A escola de educação precisa de tôdas elas e se funda no saber que esteja sendo elaborado por essas escolas, mas sua tarefa especial e maior é a de "como" ensinar e treinar, como tratar e organizar o saber para a tarefa de ensino em diferentes níveis e com diferentes objetivos (TEIXEIRA, 1969, p. 241242).

A "Escola de Professores", do Instituto de Educação do Rio de Janeiro, assume caráter profissionalizante e pretende estender ao social o método científico, a fim de organizar, acompanhar e controlar o processo educativo para que o resultado seja o previsto. 
Ainda no que se refere à institucionalização do monopólio do Estado, que se efetiva no monopólio da legislação educacional, o Decreto 19.850, de 11/04/31, cria o Conselho Nacional de Educação, órgão máximo de normatização.

No que se refere ao monopólio legislativo do Estado sobre a educação e, no caso específico sobre o Curso de Pedagogia, quatro regulamentações se efetivaram: o Decreto-lei n. ${ }^{\circ} 1.190$, de 4 de abril de 1939, quando se institui o curso de Pedagogia; a Resolução CFE n. ${ }^{\circ}$ 62, à qual se incorporou o Parecer CFE n. ${ }^{\circ}$ 251, que fixa o currículo mínimo e a duração do curso de Pedagogia; a Resolução CFE n. ${ }^{\circ}$ 2/69, a qual incorporou o Parecer n. ${ }^{\circ}$ 252/69, que fixa os mínimos de currículo e a duração do curso nas diversas habilitações (formação de professores para o ensino normal e formação de especialistas para as atividades de orientação, administração, supervisão e inspeção) e a Resolução CNE/CP n. ${ }^{\circ}$ 01, de 15 de maio de 2006, que institui as diretrizes curriculares para o curso de graduação em Pedagogia, modalidade licenciatura, fixando carga horária, mas não mais o currículo mínimo.

No que diz respeito ao Decreto n. ${ }^{\circ} 19.851$, de 11/04/31, que dispõe a organização do ensino superior no Brasil, sua vigência vai até 1968 , com a institucionalização da Lei n. ${ }^{\circ}$ 5.540, que reforma o ensino superior no Brasil, ainda em efetivo poder legal.

No Brasil, a intervenção do Estado na Educação, pelo menos, na forma da lei, inicia-se com a primeira Carta Magna, de 25 de março de 1824. Nesta, a educação é registrada como norma constitucional, mas não constituía, ainda, matéria exigida pelo Estado e não aparecia, de forma explícita e detalhada. Em seu Artigo 179, que trata da inviolabilidade dos direitos civis e políticos dos cidadãos brasileiros, nos incisos XXXII e XXXIII, consta apenas a disciplinarização, na ordem jurídica: "XXX II. A instrução primária é gratuita a todos os cidadãos." e "XXXIII. Collegios, e Universidades, onde serão ensinados os elementos das Sciencias, Bellas Artes, e Letras". Ressalta-se, porém, que a constituição não previa, expressamente, a obrigatoriedade do ensino primário, mas apenas a gratuidade "para todos".

A Constituição republicana de 1891 preocupou-se com a laicização do ensino ministrado nos estabelecimentos públicos, sem, todavia, ter assumido o Estado, expressamente, a incumbência de fazê-lo.

Mas, é na Constituição de 1934, em seu Atigo 149, que se determina que a educação é um direito de todos, administrada na família e nos poderes públicos. Nesta, garante-se o ensino primário integral e gratuito, de frequência obrigatória; garante-se a liberdade de ensino e exige que este se faça na língua pátria. Contraditoriamente, é no governo de Getúlio Vargas que se instituiu a Constituição de 1934, que legisla, explicitamente, sobre a educação pública, 
em que o Estado de certa forma assume a liderança do processo de formação humana, instituindo-a e institucionalizando algumas formas históricas que tal educação assume.

Eis o que prescreve o Artigo 150 da Constituição de 1934, quando, pelo menos na forma da lei, se explicita as competências da União:

a) fixar o plano nacional de educação, compreensivo do ensino de todos os graus e ramos, comuns e especializados; e coordenar e fiscalizar a sua execução, em todo o território do País; $\{\ldots]$

Parágrafo único - O plano nacional de educação constante de lei federal, nos termos dos arts. 5, ํㅡ XIV, e 39, ํㅜ 8, letras a e e , só se poderá renovar em prazos determinados, e obedecerá às seguintes normas: a) ensino primário integral gratuito e de freqüência obrigatória extensivo aos adultos; b) tendência à gratuidade do ensino educativo ulterior ao primário, a fim de o tornar mais acessível; c) liberdade de ensino em todos os graus e ramos, observadas as prescrições da legislação federal e da estadual;

Portanto, é na Constituição de 1934, que, na forma da lei, explicitam-se os princípios da escola pública - nacionalidade, obrigatoriedade, laicidade - e o Estado concretiza o monopólio do poder, chamando para si a responsabilidade pela educação dos cidadãos, a ser efetivada numa instituição específica - a escola. É a institucionalização do monopólio do Estado.

As decisões das questões educacionais tornam-se assunto de "especialistas" e estão a cargo do Conselho Nacional de Educação e dos Conselhos Estaduais. Dissolve-se o caráter político das decisões educacionais e mantém-se a exclusão da sociedade na construção dos sentidos da educação pública.

\subsection{A institucionalização da formação de professores}

No que concerne à institucionalização da formação de professores no Brasil, constitui também marco o conjunto de decretos da Reforma Francisco Campos: o Decreto n. ${ }^{\circ}$ 19.850, de 11 de abril de 1931, que cria o Conselho Nacional de Educação; o Decreto n. ${ }^{\circ}$ 19.851, de 11 de abril de 1931, que dispõe a organização do ensino superior no Brasil e adota o regime universitário; o Decreto n. ${ }^{\circ}$ 19.852, de 11 de abril de 1931, que determina a organização da Universidade do Rio de Janeiro; o Decreto n. ${ }^{\circ}$ 19.890, de 18 de abril de 1931, que dispõe a organização do ensino secundário; e o Decreto $\mathrm{n}^{\circ} 21.241$, de 14 de abril de 1932, que 
consolida as disposições sobre a organização do Ensino Secundário. Todavia, no que tange à formação de professores na escola normal, não logrou nenhuma instituição reformadora, ficando marginalizados tanto o ensino normal como o primário.

Para Tomazetti (2001):

\begin{abstract}
A formação de professores para o ensino secundário somente foi institucionalizada a partir da criação, em 1934, da Faculdade de Filosofia, Ciências e Letras da USP e, em 1939, com a instituição do modelo imposto pela Faculdade Nacional de Filosofia, FNFi. A consolidação de um novo ensino normal, sustentado nas ciências da educação e o surgimento das faculdades de filosofia, ciência e letras foram os elementos significativos em relação às preocupações com a institucionalização da formação de professores no Brasil (p. 445).
\end{abstract}

Sob essa base é que, em 1939, foram instituídos os cursos de Pedagogia e de Licenciatura na Universidade do Brasil (na qual foi transformada a Universidade do Rio de Janeiro, em 1937) e na Universidade de São Paulo. Daí, emergiu o paradigma que, adotado pelas demais instituições de ensino superior do país, equacionou a questão relativa à formação de professores para o ensino de nível secundário e para as próprias escolas normais. Aos cursos de Licenciatura coube a tarefa de formar professores para as disciplinas específicas que compunham os currículos das escolas secundárias, e os cursos de Pedagogia ficaram com o encargo de formar os professores das escolas normais. Sobre o curso de Pedagogia no Brasil, Bissolli da Silva (2003) tomou como base os documentos legais que o regulamentaram. O primeiro marco temporal é em 1939, com o decreto-lei n. ${ }^{\circ} 1.190$, de 4 de abril de 1939:

O curso de pedagogia foi instituído entre nós por ocasião da organização da Faculdade Nacional de Filosofia, da Universidade do Brasil, através do decreto-lei n. ${ }^{\circ} 1.190$ de 4 de abril de 1939. Visando a dupla função de formar bacharéis e licenciados para várias áreas, inclusive para o setor pedagógico, ficou instituído, por tal documento legal, o chamado "padrão federal" ao qual tiveram que se adaptar os currículos básicos dos cursos oferecidos pelas demais instituições do país. O curso de pedagogia foi previsto como o único curso da "seção", de pedagogia que, ao lado de três outras - a de filosofia, a de ciências e a de letras - com seus respectivos cursos, compuseram as "seções", fundamentais da Faculdade. Como "seção" especial foi instituída a de didática, composta apenas pelo curso de didática. Foram fixados os currículos plenos e também a duração para todos os cursos. Para formação de bacharéis ficou determinada a duração de três anos, apos os quais, adicionando-se um ano de curso de didática, formar-se-iam os licenciados, num esquema que passou a ser conhecido como " $3+1$ " [...].

O curso de pedagogia ficou assim seriado: complementos de matemática ( $1^{\mathrm{a}}$ série), história da filosofia ( $1^{\mathrm{a}}$ série), sociologia $\left(1^{\mathrm{a}}\right.$ série$)$, fundamentos biológicos da educação ( $1^{\mathrm{a}}$ série), psicologia educacional $\left(1^{\mathrm{a}}, 2^{\mathrm{a}}\right.$ e $3^{\mathrm{a}}$ séries $)$, estatística educacional ( $2^{\mathrm{a}}$ série), história da educação $\left(2^{\mathrm{a}}\right.$ e $3^{\mathrm{a}}$ séries), fundamentos sociológicos da educação ( $2^{\mathrm{a}}$ série), administração escolar ( $2^{\mathrm{a}}$ e $3^{\mathrm{a}}$ séries), educação comparada ( $3^{\mathrm{a}}$ série), filosofia da educação ( $3^{\mathrm{a}}$ série).

O curso de didática ficou constituído pelas seguintes disciplinas: didática geral, didática especial, psicologia educacional, administração escolar, fundamentos biológicos da educação, fundamentos sociológicos da educação. (BISSOLLI da SILVA, 2003, p. 11-12). 
Contudo, se a proposta que deu origem ao modelo privilegiava a formação dos novos professores nas escolas experimentais, como é o caso da Universidade do Distrito Federal (UDF) e Universidade de São Paulo (USP), sob a influência, respectivamente de Anísio Teixeira e Fernando Azevedo, fornecendo, com isso, uma base de pesquisa que pretendia dar caráter científico aos processos formativos, a generalização do modelo concentrou a formação no aspecto profissional, que seria garantido por um currículo composto por um conjunto de disciplinas a serem frequentadas pelos alunos, dispensada a exigência de escolas-laboratórios.

Observa-se que, entre as disciplinas que compõem o curso de Pedagogia, têm-se, na $1^{\mathrm{a}}$ série, a História da Filosofia, e na $3^{\text {a }}$ e última série, a Filosofia da Educação.

Para Bellochio et al. (2004):

Constituir uma dimensão técnica e profissional à formação do professor primário era
uma proposição apresentada no discurso dos intelectuais da época e era sintoma da
tomada de conhecimento das teses da Escola Nova e dos currículos das Escolas
Normais americanas. Nestas, haviam sido introduzidas disciplinas consideradas
efetivamente de caráter pedagógico/científico como a psicologia da educação, a
história da educação, a sociologia da educação e a filosofia da educação. [...]
Consequentemente, esse corpo de saberes pedagógicos oriundos das Ciências da
Educação era produzido por um grupo de pesquisadores e estudiosos vinculados à
universidade que seriam os formadores de professores. Ao mesmo tempo, a prática
docente passou a assimilar as possibilidades de procedimentos técnicos,
metodologicos e profissionais. Constituiu-se dessa forma, uma divisão entre aqueles
que produzem os saberes científicos e pedagógicos (os formadores de professores da
escola normal e da universidade) e os professores da escola, que na sua prática
educativa aplicavam os referidos saberes (p. 4-5).

Observa-se, portanto, uma divisão do trabalho educativo, em que pesquisadores e estudiosos vinculados à universidade são alçados à condição de experts na produção do conhecimento educativo, restando aos professores das escolas primárias e secundárias apenas o mero papel de aplicadores dos saberes produzidos pelos experts. Ocorre, no campo educacional, a oposição pesquisadores/estudiosos versus professores, dividindo o trabalho que concerniria a todos: pensar a educação e praticá-la.

No que concerne às outras licenciaturas, não há oferecimento de nenhuma disciplina de Filosofia da Educação ou até mesmo de História da Filosofia. Ressalta-se como problemática, já nas origens da institucionalização da formação de professores, a identificação do profissional a ser formado como bacharel, agravado pela Lei Orgânica do Ensino Normal Decreto-lei $\mathrm{n}^{\circ} 8.530 / 46$, que definia, como exigência para atuar no curso normal, apenas a posse de diploma de curso superior.

Instituída a formação de professores para as escolas normais e secundárias, mediante o decreto-lei n ${ }^{o} 1.190$, de 04 de abril de 1939, o Estado, por meio do Conselho Nacional de Educação, só em 1962 intervirá, pela segunda vez, no curso de Pedagogia, instituindo o 
Parecer CFE n. ${ }^{\circ}$ 251, incorporado à Resolução CFE n. ${ }^{\circ}$ 62. Neste, são fixados o currículo mínimo e a duração do Curso.

Segundo Bissoli da Silva (2003):

Para o bacharelado, o currículo mínimo era fixado em sete matérias, sendo cinco
obrigatórias e duas opcionais, as obrigatórias eram: psicologia da educação,
sociologia (geral, da educação), história da educação, filosofia da educação e
administração escolar. As opcionais eram: biologia, história da filosofia, estatística,
métodos e técnicas de pesquisa pedagógica, cultura brasileira, educação comparada,
higiene escolar, currículos e programas, técnicas audiovisuais de educação, teoria e
prática da escola média e introdução à orientação educacional.
O aluno interessado na licenciatura deveria cursar também didática e prática de
ensino. [...] (p. 16).

Constituíam matérias obrigatórias as chamadas disciplinas de fundamentos da educação: Psicologia, Sociologia, História e Filosofia da Educação. Compreendidas como fundamentos, alicerce, as disciplinas de Psicologia, Sociologia e História da Educação tinham o papel de possibilitar ao pedagogo o conhecimento dos discentes, no que se refere a si e ao seu desenvolvimento, à realidade social-histórica e às teorias elaboradas sobre ela, bem como o modo de se efetivar a educação em cada social-histórico. A Filosofia da Educação compunha o quadro dos fundamentos, composta por conhecimento das grandes matrizes teóricas filosóficas, das quais se deduziam explicações sobre natureza, natureza humana, conhecimento e valores sociais. A inclusão da disciplina Administração Escolar no elenco das obrigatórias explica-se pelas finalidades atribuídas à Faculdade Nacional de Filosofia, na priorização da formação do bacharel: "trabalhadores intelectuais para o exercício das altas atividades culturais de ordem desinteressada ou técnica." (artigo $1 .^{\circ}$, alínea a) e pelo papel atribuído à disciplina: a base da formação específica do chamado técnico da educação.

Após a reforma da educação superior - Lei 5.540, de 28 de novembro de 1968, em que triunfam os princípios da racionalidade, da eficiência e da produtividade, o curso de Pedagogia é novamente reformulado, mediante a institucionalização do Parecer do CFE n. ${ }^{\circ}$ 252/69, que é incorporado à resolução CFE n 2/69. É o momento em que o Estado intervém, de forma explícita e numa perspectiva tecnicista, e define para o curso de Pedagogia, dupla finalidade: a de formação de professores para o ensino normal e a de especialistas para as atividades de orientação, administração, supervisão e inspeção, no âmbito dos sistemas escolares. No contexto pós-golpe militar, dos convênios MEC-USAID, confirma-se a correspondência direta e imediata entre currículo e tarefas a serem desenvolvidas em cada profissão. Prevalece a tendência tecnicista na educação e são fixados os mínimos de currículo e a duração para o curso. O currículo compõe-se de uma parte comum e de uma parte diversificada, para atender às habilitações específicas. No que diz respeito a este trabalho, 
interessa a parte comum do currículo, composta pelas seguintes matérias: Sociologia Geral, Sociologia da Educação, Psicologia da Educação, História da Educação, Filosofia da Educação e Didática. Esta parte comum compreende os fundamentos da educação, acrescidos, agora, de Sociologia Geral e Didática. A inclusão de Sociologia Geral não significa que as demais matérias, contidas na parte comum, possam "[...] prescindir da sua própria fundamentação geral como suporte para a abordagem pedagógica" (BRASIL, CFE, Documenta, n. ${ }^{\circ}$ 100, p. 106-107). Assim, as matérias Psicologia, Sociologia, História e Filosofia da Educação não poderão ser ministradas, se forem desconsiderados os conhecimentos produzidos nas áreas de Psicologia, Sociologia, História e Filosofia, das quais são tributárias. No que se refere à Didática, segundo Bissolli da Silva (2003):

Três argumentos são utilizados para justificar a inclusão da didática como matéria da parte comum: ela se identifica com o ato de ensinar para o qual as outras matérias convergem; todos poderão lecionar, nos cursos normais, as disciplinas de suas habilitações específicas e, por fim, considerou-se que, invariavelmente, as universidades e escolas isoladas já a vinham incluindo em seus currículos plenos (p. 27).

Dos fins da década de 70 até o momento, professores e estudantes universitários organizaram-se e mobilizaram-se para intervir no processo de reforma do curso de Pedagogia. Assim, merecem destaque o I Seminário de Educação Brasileira, realizado na Universidade de Campinas, em 1978; a I Conferência Brasileira de Educação, realizada na Pontifícia Universidade Católica (PUC) de São Paulo, em 1980; a criação do Comitê Nacional PróReformulação dos Cursos de Formação de Educadores; a realização de Seminários Regionais de Recursos Humanos para a Educação, organizados pela Secretaria de Educação Superior do Ministério de Educação e Cultura, a partir de 1981; a Comissão Nacional de Reformulação dos Cursos de Formação do Educador (CONARCFE), posteriormente intitulada Associação Nacional pela Formação dos Profissionais da Educação (ANFOPE); os Congressos Estaduais Paulista sobre Formação de Educadores, realizados pela Universidade Estadual Paulista Júlio de Mesquita Filho (UNESP) a partir de 1990. Ressalta-se, sobretudo, o trabalho desenvolvido pela ANFOPE, seja em seus encontros nacionais e regionais, seja como interlocutor junto às instâncias do MEC-SESU, com vistas na elaboração das diretrizes curriculares dos cursos de formação de educadores, com participação desta entidade.

Os movimentos dos educadores, capitaneado pela ANFOPE, e dos estudantes de Pedagogia fervilharam durante as décadas de 70 a 90, e ainda continuam efetivos. Todavia, pela quarta vez, o Estado, por meio da SESU-MEC, em 2006, instituiu as diretrizes 
curriculares para o curso de Pedagogia, mediante a Resolução $\mathrm{CNE} / \mathrm{CP}$ n. ${ }^{\circ}$ 01, de 15 de maio de 2006.

Interessa explicitar, na institucionalização dos cursos de formação de professores secundários, inclusive dos pedagogos das faculdades de Filosofia, Ciências e Letras, a identidade da disciplina Filosofia da Educação, tanto quanto os saberes e conteúdos com ela relacionados.

\title{
3.3 A tentativa de adoção do cientismo da Educação
}

Tudo indica que, nos dias de hoje, é a ciência que se encontra instalada no lugar de Deus. Desde há algum tempo, ela vem se atribuindo o papel de referência absoluta. Impõe-se o positivismo, que gera o cientificismo.

Japiassu

Na relação entre filosofia e educação, que faz da segunda, objeto de reflexão da primeira, situa-se a questão da formação do homem. Podem-se responsabilizar os cursos de formação de professores pela perspectiva que a disciplina de Filosofia da Educação assume como estudo das ideias pedagógicas dos filósofos, apresentada nos manuais de pedagogia ou de história da pedagogia ou história da educação e da filosofia.

Para Tomazetti (2000a):

\begin{abstract}
Embora a idéia de formação geral do homem tenha sua origem no pensamento dos filósofos gregos, a história da filosofia, de maneira geral, tem demonstrado que os filósofos sempre compreenderam a educação enquanto um processo de formação. Por isso, o filósofo pode ser considerado o iniciador do discurso sobre a educação, um discurso que buscou apreender a totalidade da educação, procurando responder às questões: que é o ato de educar?; qual a natureza da relação entre educador e educando?; qual o fim da educação? E, mais: que tipo de educação é o mais apropriado para desenvolver integralmente o homem, isto é, desenvolver suas potencialidades, sua essência? A preocupação dos filósofos com a educação definiase, consequentemente, como uma preocupação com o processo de formação geral do homem. (p. 1-2).
\end{abstract}

Ao historiar a constituição do campo da Filosofia da Educação, a autora assim o apresenta: até o século XVII, vige o filósofo-preceptor, que mantém relação educativa individual com a criança, sem nenhuma preocupação com a educação escolar; em fins do século XVIII, o pensamento sobre a educação tem como objeto a formação geral do homem, acrescida agora, da tematização da escolarização; do fim do século XIX ao início do século XX, a reflexão filosófica tematiza a educação, sob as mais diversas denominações pedagogia geral, pedagogia filosófica, ciência da educação, filosofia da educação; no século 
$\mathrm{XX}$, iniciam-se as tentativas de diferenciar o discurso científico do filosófico sobre educação. No século XXI, há espaço para a Filosofia da Educação, sem especificação de seu objeto e de seu sentido?

Todavia, se a história da cultura greco-ocidental constitui uma evidência da relação da filosofia com a educação, tal relação se faz, talvez, esmaecida, na última metade do século XX, sob a influência do positivismo e do neopositivismo. Para Warde (1990),

\begin{abstract}
Observação, experimentação e comparação são as regras básicas da ciência positiva; ciência que universaliza para o estudo dos fatos humanos as leis da natureza. Educar-se nas suas regras é aprender a aceitar as leis da sociedade como se aceita as leis da natureza; é imbuir-se do espírito positivo que rejeita a "negatividade" como princípio do conhecimento e como princípio político. Nessa concepção, conteúdo (teoria social) e método (regras de observação, experimentação e comparação), subjetividade e objetividade se identificam, pela dissolução dos primeiros termos nos segundos (p. 28).
\end{abstract}

No que tange à educação, essa influência se traduz no movimento educacional da Escola Nova, que surgiu no final do século XIX, numa tentativa de superar a pedagogia da essência.

Para Tomazetti (2001):

No final do século XIX manifestaram-se as primeiras preocupações, no Brasil, com
a cientificidade da Pedagogia, quanto os estudos sobre novos métodos de ensinar
passaram a dominar as questões educacionais. Era o momento da primeira inserção
das idéias sobre a escola nova, ancorada nos conhecimentos científicos da psicologia
e da sociologia. No entanto, a filosofia foi o primeiro saber a dar as bases de
sustentação do discurso pedagógico, gerando uma indistinção entre discurso
filosófico sobre educação e um discurso pedagógico geral. [...]
Com uma referência específica ao Brasil, a partir deste estudo foi possível constatar
que sua institucionalização, como disciplina ocorreu posteriormente à psicologia, à
sociologia e, mesmo à história da educação em algumas instituições de ensino
normal. Por outro lado, seu surgimento no currículo dos cursos de formação de
professores secundários nas faculdades de filosofia, ciências e letras, das
universidades, ocorreu dentro de uma cadeira denominada História e Filosofia da
Educação (p. 445-446).

Embora os conhecimentos filosóficos tenham se apresentado no currículo dos cursos de formação de professores secundários, no Brasil, até os anos 60, sob a denominação da disciplina História e Filosofia da Educação, eles apareciam também em disciplinas denominadas de Filosofia, Pedagogia, Teoria da Educação, Introdução à Filosofia.

No Brasil, o movimento escolanovista começou no século XX (1920), traduzindo-se, de maneira sistemática, no Manifesto dos Pioneiros da Escola Nova, de 1932 e em reformas estaduais do ensino público elementar, principalmente nos estados de São Paulo, Minas Gerais, Bahia e Distrito Federal (Rio de Janeiro). Seus principais representantes foram Lourenço Filho, Fernando de Azevedo e Anísio Teixeira. 
No artigo Formar o mestre na universidade: a experiência paulista nos anos de 1930, Evangelista (2001) citou posicionamentos de Fernando de Azevedo, quando da coordenação do inquérito de $O$ Estado de S. Paulo:

[...] a universidade como lugar preferencial para abrigar a formação do professor secundário $[\ldots]$ o preparo docente devia estar marcado por uma faceta técnica, tanto da ótica dos conteúdos de sua formação, quanto da do local apropriado para tal, um instituto [...] o professor deveria "conhecer os fins, os meios e os métodos do seu ensino e saber justificá-los cientificamente", sendo educador pela capacidade de produzir e organizar valores espirituais [...] (p. 250).

No Estado de São Paulo, com a reforma educacional, foi criado em 1933, por Fernando de Azevedo, o Instituto de Educação de São Paulo, escola de formação profissional de docentes de nível superior.

Segundo Evangelista (2001):

A idéia de formação técnico-profissional estava amarrada a uma particular compreensão de ciência. Segundo Monarcha (1992), no caso da Psicologia e da Biologia, ocorreu uma apropriação da ciência sob forma instrumental, transformada em suporte de uma série de iniciativas no campo político, econômico e educacional. Seu uso deu-lhe feição técnica, a partir da qual se podia exigir que os funcionários do Estado - ou as elites dominantes - se pautassem por conduta técnica, aparentemente oposta à conduta política, própria da "tradição". (p. 251).

Com a criação da USP, em 1934, pelo governo do Estado de São Paulo, a Faculdade de Filosofia, Ciências e Letras (FFCL) incorporou o Instituto de Educação, e:

Seu grande desiderato era imprimir ao ensino "um caráter acentuadamente experimental", no movimento "dos laboratórios ao ensino". Os laboratórios Psicologia Educacional, Biologia Educacional, Pesquisas Sociais e Educacionais e Estatística - foram fundamentais na vida do Instituto precisamente porque neles se operavam as "verificações objetivas" das teorias, as "experimentações", as "observações", as "práticas"”. Por seu intermédio permitia-se a demonstração aos círculos intelectuais emergentes, da inexorabilidade da ciência e da correção técnica, científica e moral - de suas teorias. (AZEVEDO, 1946, p. 61 apud EVANGELISTA, 2001, p. 448).

Fernando de Azevedo, um dos expoentes do movimento escolanovista, tinha preocupação com o avanço das ciências no campo educacional:

Certamente, as ciências que residem à base da educação (biologia, psicologia, etc.) subministram à técnica instrumentos preciosos de ação, mas, como lembra Leonel Franca, é uma concepção de vida que lhe orienta a aplicação, subordinando os meios aos fins; e uma vez que os fins da educação se perderem de vista, todo obra educacional tende a limitar-se aos detalhes da prática e a reduzir-se, sem finalidade, e, portanto, sem sentido a um puro jogo de processos e de técnicas (AZEVEDO, 1957, p. 281 apud TOMAZETTI, 2001, p. 447-448).

Ainda para esse autor, seria papel do filósofo da educação interrogar-se:

[...] quais os fins que a educação deve ter, dentro de determinada concepção de vida e de mundo, isto é, dado um sistema filosófico, qual a doutrina pedagógica que daí resulta: podem-se, assim estudar paralelamente as doutrinas filosóficas e as 
doutrinas pedagógicas e ver como estas nascem daquelas e, dado um sistema filosófico, de Platão ou de Aristóteles, de Descartes ou de Kant, deduzir a filosofia da educação que lhe corresponde (AZEVEDO, 1957, p. 291 apud TOMAZETTI, 2001, p. 448).

Para Fernando de Azevedo, o papel do filósofo da educação é o de interrogar-se sobre os fins que a educação deve ter, para deles deduzir a filosofia da educação que lhe corresponde. Todavia, é tributário de sua formação sociológica retirar da Filosofia da Educação a determinação dos fins que a educação deve almejar, atribuindo sua fixação à Sociologia da Educação. Assim, para ele:

Uma política de educação pressupõe, portanto, uma filosofia da educação. Mas, por
isto mesmo que uma "política de educação" se propõe estabelecer fins a atingir em
dada situação histórica de um povo, os objetivos não podem ser fixados a rigor, por
especulação puramente teórica, sem levar em consideração as condições concretas
do meio e as aspirações e necessidades coletivas. Não é em uma filosofia
educacional, deduzida logicamente de qualquer sistema filosófico, que se tem de
edificar a política de educação, que não se poderá evazar, se a quisermos fazer viver,
do seu conteúdo sociológico (AZEVEDO, s.d., p. 140).

Dessa forma, como os fins da educação eram instituídos pela Sociologia da Educação, restava à Filosofia explicitar o sistema filosófico e a doutrina pedagógica dele decorrente. Caminha-se, pois, para uma abordagem da Filosofia da Educação que não se interroga, mas que se deduz de um sistema filosófico.

Ao analisar tal posicionamento, Tomazetti (2001) concluiu que

À filosofia da educação caberia, então, o estudo das teorias educacionais e a dedução de implicações educacionais, principalmente dos fins, a partir dos diferentes sistemas filosóficos" (p. 49).

Essa "conclusão" da autora reproduz as posições explicitamente defendidas por Azevedo e por outros autores sobre a tarefa da Filosofia da Educação - que assim se dessolidariza do social-histórico e do fenômeno educativo, tornando-a apenas a apresentação formal de teorias filosóficas já elaboradas e a dedução de suas aplicações. Ainda que se reconheça a importância dos clássicos para auxiliar o pensar sobre a educação e para compreender como, em cada contexto social-histórico, ela foi pensada e praticada, é impossível não observar que tal posição implica numa demissão de reflexão sobre a educação, substituída pela apresentação do "já pensado" pela filosofia, sempre em prejuízo do pensamento vivo e da prática inovadora.

Para Tomazetti (2001):

[...] a tradição do ensino de filosofia da educação no Brasil foi em grande medida, o estudo das idéias sobre educação de importantes filósofos no contexto da história da filosofia. [...] A dimensão histórica da filosofia e da educação/pedagogia era concretizada com o estudo de pensadores clássicos e das principais correntes filosóficas. A filosofia da educação sustentava-se na apresentação do pensamento 
dos filósofos, extraindo suas idéias acerca da educação. Ensinar filosofia da educação era, quase sempre, descrever a história do pensamento educacional/filosófico. A partir dessa descrição, extraiam-se as temáticas características do saber filosófico da educação, como a ética, a estética, o homem, o conhecimento, os valores e os fins, em sua relação com a educação. (p. 450).

É a essa atitude conservadora, que marca tanto o curso de Filosofia como a disciplina de Filosofia da Educação, que se pode imputar a "denegação da dimensão instituinte", de que falava Castoriadis (1992) e que é responsável pela “[...] criação de indivíduos absolutamente conformes, que vivem e se pensam, na repetição [...], cuja imaginação radical é reprimida o mais possível, indivíduos que quase não são verdadeiramente individuados.” (p. 139).

Em posição diversa, encontra-se outro escolanovista, Anísio Teixeira, que, em 15 de outubro de 1931, assumiu a Diretoria da Instrução Pública do Rio de Janeiro, em substituição a Fernando de Azevedo. Em sua gestão, efetiva-se a reforma da Escola Normal, que passa a constituir o Instituto de Educação, e cria-se a Universidade do Distrito Federal (UDF), composta pelas Escolas de Ciências, de Economia e Direito, de Filosofia e Letras, Instituto de Artes e Instituto de Educação, sendo este resultante da incorporação da Escola de Professores do Instituto de Educação do Rio de Janeiro, que passa a denominar-se Escola de Educação.

Todavia, a existência da UDF foi efêmera. Em 20 de janeiro de 1939, com o decretolei n. ${ }^{\circ}$ 1.063, Getúlio Vargas a extinguia, transferindo seu acervo e corpo docente para a Universidade do Brasil. Assim, os modelos de formação de professores, propostos pela UDF e pela Universidade de São Paulo, são substituídos pelo modelo da Faculdade Nacional de Filosofia, instituída pelo Decreto-lei n. ${ }^{\circ}$ 1.190, de 04 de abril de 1939.

Mas, quem era Anísio Teixeira como pensador da educação?

As ideias de Anísio sobre ciência, educação e filosofia são marcadas pela influência de Dewey e do pragmatismo norte-americano e expressam uma clara função social da Filosofia.

Ao assumir o conceito de William James, de "[...] que todos possuímos uma filosofia, que é o sentido mais ou menos obscuro ou lúcido que temos do que a vida, honesta e profundamente, significa para cada um de nós” (TEIXEIRA, 1971, p. 146), isto é, de que cada um constrói a sua filosofia, dele deduz seu conceito de Filosofia da Educação: “[...] estudo dos problemas que se referem à formação dos melhores hábitos mentais e morais em relação às dificuldades da vida social contemporânea" (TEIXEIRA, 1971, p. 148).

Se a Filosofia, até a modernidade, pode ser definida como o fez John Dewey “justificação em fundamentos racionais, do espírito, embora não da forma, das crenças e costumes tradicionais" (TEIXEIRA, 1971, p. 139), numa tentativa de conciliar o mundo do conhecimento empírico e experimental com o do conhecimento tradicional e religioso, nos 
tempos modernos, ela se reconstrói como atitude de auxiliar a estabelecer método para julgar os valores, os sentidos e as interpretações da vida, para dirigi-la para uma vida melhor.

É nesse sentido que o autor concebe a Filosofia: como filosofias individuais, consequência da experiência de cada um; como sistemas filosóficos, criações pedantes de gabinete; produções filosóficas de uma época, de uma cultura, de uma civilização, consubstanciadas em programa de ação e de conduta.

Assim, seria tarefa dos filósofos pensar as questões fundamentais do seu tempo e encontrar um programa de ação que apresentasse explicações e respostas. Daí, porque “[...] o método filosófico será, assim, experimental, no sentido de que as soluções propostas serão hipóteses sujeitas à confirmação das conseqüências” (TEIXEIRA, 1971, p. 148).

Em seu livro Pequena introdução à Filosofia da Educação: a escola progressiva ou a transformação da escola, Anísio Teixeira apresenta três diretrizes, por onde está se processando a reconstrução da vida na modernidade, decorrentes da aplicação da ciência à civilização humana.

A primeira diz da nova atitude espiritual do homem, de segurança, de otimismo e de coragem, em substituição à velha atitude de submissão, de medo e de desconfiança na natureza humana. Entretanto, “[...] o ato de fé do homem esclarecido não repousa nas conclusões da ciência, repousa no método científico, que lhe está dando um senso novo de segurança e responsabilidade" (TEIXEIRA, 1971, p. 31). A ideia do progresso ilimitado se constrói sobre a experimentação científica, que, doravante, reivindicou a eficácia do pensamento humano. Assim, institui-se a crença na ciência, no método científico e em suas aplicações técnicas, como instrumento de controle que o homem detém sobre a realidade natural e social.

De acordo com o mesmo educador, “[...] a segunda grande diretriz de vida moderna é o industrialismo, como a nova visão intelectual, do homem, também filho da ciência e da sua aplicação à vida” (p. 33).

O desenvolvimento industrial era apresentado por ele como potencializador de uma completa exploração dos recursos materiais existentes. Ressaltavam-se as maravilhas do industrialismo: o poder do homem de manipulação da natureza e a eficiência e a eficácia das máquinas no mundo do trabalho, das comunicações, do transporte. Embora apontasse os malefícios do industrialismo, ou seja, a desintegração do trabalho individual, da família, da cidade, a superespecialização do trabalho, alienação do trabalhador, acreditava que esses problemas deveriam ser resolvidos pela educação, para que se construísse a integração da "grande sociedade". 
Ä terceira diretriz constitui a tendência democrática. Para o autor, a “[...] democracia é, essencialmente, o modo de vida social em que "cada indivíduo conta como uma pessoa. [...] Personalidade e cooperação são os dois pólos dessa nova formação humana que a democracia exige."' (1971, p. 35). Ao entender a democracia como um modo de vida social, na qual prevalece o respeito pelo homem, afirma ser ela uma corrente moderna, que mais de longe se filia à ciência.

Considerando que essas três diretrizes da vida moderna - a formação do novo homem, o industrialismo e a democracia - eram consequência da transformação socioeconômica da sociedade pela aplicação da ciência, propugnava-se uma nova educação, que se concretizaria na nova escola, a escola progressiva.

Assim,

\begin{abstract}
A grande transformação estará em fazer da conduta moral do homem uma consequiência dos conhecimentos positivos a que o homem vai chegando em fisiologia e em psicologia. Quando chegarmos a conceber o mal como um simples funcionamento anormal dos órgãos bio-sociais do homem - digamos assim -, e tivermos para com ele a mesma atitude experimental que temos para os males físicos, teremos dado o primeiro passo para uma ciência moral.

Nesse sentido, toda a humanidade é um grande laboratório, onde se ensaiam, com maior ou menor consciência, métodos e experiências de reconstrução material, social e moral (TEIXEIRA, 1971, p. 108-109 e 198).
\end{abstract}

Embora tenha atuado, quase sempre, na administração pública na educação brasileira, Anísio Teixeira está vinculado ao campo da Filosofia da Educação no Brasil. Sua contribuição se deu no âmbito da produção editorial, da divulgação do pensamento e da obra de John Dewey e da filosofia pragmatista. Se seus trabalhos marcaram o campo educacional entre os anos 20 e 60, o mesmo não se pode dizer da sua influência na disciplina Filosofia da Educação.

Na década de 60, após 13 anos de debates, é institucionalizada a Lei de Diretrizes e Bases da Educação Nacional - Lei 4.024/61 e Lei 5.540/68, que regulamenta a educação superior. Ainda na década de 70 , é novamente reformado o ensino de $1 .^{\circ}$ e $2 .^{\circ}$ graus - Lei 5.692/71. Essas duas décadas são marcadas de forma acelerada, por uma perspectiva tecnológica que lhe imputa o nome de período tecnicista da educação.

Mas, se a ciência e a técnica se tornaram os ícones da sociedade moderna, elas só podem ser pensadas e elucidadas no social-histórico, pois, ao se instituir uma sociedade, instituem o fazer e o representar/dizer social, os quais se fazem nas dimensões imaginária e conjuntista-identitária. 
Consubstanciados à lógica identitária e constituindo as dimensões estruturadoras da instituição social-histórica, o legein e o teukhein significam a forma de captação, percepção e tematização do mundo-linguagem e da instituição da técnica como o fazer social.

Interessa, nesse momento, a questão do teukhein - a instituição da técnica como o fazer social, que se materializa na própria organização social - a rede de relações sociais, que é a própria instituição. Mas a instituição não se reduz à técnica, ela a contempla e inexistiria sem ela. A instituição é, também, dimensão imaginária, que se institui nas significações sociais.

Castoriadis enfatiza, assim, a impossibilidade de "[...] separar as significações do mundo estabelecidas por uma sociedade, sua "orientação" e seus "valores", do que é para ela o fazer eficaz [...]" (1987a, 311), o que se faz, ao tomar a sociedade moderna, pensar a realidade socioeconômica que se institui - o capitalismo e a significação social que enraíza: a expansão ilimitada do "domínio racional". Castoriadis toma de Marx, os determinantes do capitalismo: "A acumulação das forças produtivas combinada à transformação sistemática dos processos de produção e de trabalho e aquilo que ele chamou de "aplicação racional da ciência ao processo de produção.” (2004, p. 98) e apresenta duas de suas características essenciais.

A primeira diz respeito ao impulso para a dominação. Ora, a significação imaginária social da expansão ilimitada do "domínio racional” penetra, primeiro, na esfera da produção, porque as mudanças da técnica permitem uma racionalização dominadora. Mas todas as esferas da vida social são visadas. Assim, se a economia e os critérios econômicos são centrais na vida social capitalista, a expansão ilimitada do "domínio racional" penetra, também, no consumo e na totalidade da vida social - no Estado, na educação, no direito, na vida política etc.

A segunda característica é a racionalização, "novo modus faciendi" - "racional", isto é, "econômico". O que importa é a maximização do lucro e a minimização dos custos.

Assim, razão, racionalidade e racionalização tornam-se universalmente influentes. Mas, para o filósofo (1992) “[...] a Razão, processo aberto de crítica e elucidação, transforma-se de um lado em computação mecânica e uniformizante [...], e de outro lado em sistema universal e pretensamente exaustivo [...]" (p. 21), isto é, a razão torna-se a justificativa de si própria, o fundamento autosuficiente da atividade humana e o tribunal perante o qual tudo e todos serão julgados e medidos. A racionalidade transforma-se em comportamento adequado à obtenção de maximização de metas que não podem ser obstruídas pelo humano, pela tradição etc. O que importa é tornar mais eficientes os processos de 
produção, organização e planejamento, pelo emprego de métodos científicos e instrumentos tecnológicos. A racionalização implica um recurso maior, em níveis de planejamento e controle, a critérios de utilidade racionais. A racionalização é a utilização de métodos produzidos pela ciência, que objetivam o ajuste ótimo dos meios aos fins, para que todo esforço produza um resultado máximo.

Tornados valores absolutos da sociedade moderna, pelos seus resultados, a ciência e a técnica transformam-se em nova ideologia e novos mitos: como ideologia, a ciência é crença no poder do homem de explicar, totalmente, a realidade natural e social e de poder controlálas inteiramente por meio da técnica; é crença no progresso e na evolução contínua dos conhecimentos. Como novo mito, a ciência é crença no poder ilimitado que o humano adquire sobre coisas e humanos. Segundo Castoriadis (1987a),

[...] a natureza, o valor, a orientação, o modo de produção e os produtos desse saber lhe parecem acima de qualquer discussão, dogmas que em nada diferem, quanto à solidez e ao modo de adesão subjetiva, dos dogmas religiosos que reinavam recentemente. (p. 201-202).

Esse progressismo científico e essa atitude cientificista de fé infundada de que a ciência pode e deve tudo conhecer e dominar, e mesmo de que ela o faz ao produzir explicações causais para a realidade natural e social, cravaram o tecido da sociedade ocidental.

No Brasil, também a educação, no final dos anos 20, é perpassada por essa ideologia e mitologia, com a introdução nas escolas normais de disciplinas, princípios e práticas inspirados no escolanovismo.

De acordo com Evangelista (2001):

\begin{abstract}
A idéia da formação técnico-profissional estava amarrada a uma particular compreensão da ciência. Segundo Monarcha (1982), no caso da Psicologia e da Biologia, ocorreu uma apropriação da ciência sob forma instrumental, transformada em suporte de uma série de iniciativas no campo político, econômico e educacional. Seu uso deu-lhe feição técnica, a partir da qual se podia exigir que os funcionários do Estado - ou as elites dominantes -, assim como os intelectuais, se pautassem por conduta técnica, aparentemente oposta à conduta política, própria da "tradição" (p. 251).
\end{abstract}

Esse conflito entre modernidade e tradição acirrar-se-á a partir de 1930, quando da institucionalização da formação universitária do professor, no embate entre católicos e liberais.

A modernização da educação, que confere um estatuto de cientificidade à Pedagogia, tem a sua fonte nos conhecimentos da Psicologia, da Sociologia e da Biologia. Tais ciências, ao incorporarem o método científico e constituírem a sua objetividade, tinham se 
autonomizado da Filosofia e constituíam a tríade das ciências da educação. Mas, e a Filosofia? Compreendida, no início, como a totalidade do saber, a Filosofia foi excluída como ciência da educação e era, agora, objeto de enfrentamento da objetividade das ciências humanas, principalmente por causa da Metafísica.

Nessa modernização educacional:

[...] a) o conceito de atividade científica passou a ser definido a partir da racionalidade presente na esfera da produção; b) há uma repolitizacão do discurso pedagógico, no qual o padrão técnico recobre a dimensão política; e c) a sociedade é concebida como uma anterioridade ao indivíduo, gerando a necessidade de promover a sua adaptação à sociedade (MONARCHA, 1992, p. 47).

Assim, os problemas educacionais eram tratados numa perspectiva estritamente técnica, "científica", sem nenhuma conexão com o social-histórico, o que irá perdurar na história da educação brasileira.

Conforme Severino, em sua tese de livre docência, A educação, o sujeito e a históriaidentidade e tarefas da Filosofia da Educação (2000a):

Há dois grandes âmbitos do agir humano que introduzem esta especificidade no
campo das ciências humanas: trata-se do campo da política e do campo da educação,
o que implica que apenas a ciência política e a ciência da educação perfilam uma
fisionomia própria, distinta daquela das demais ciências humanas, nas quais é
possível desenvolver uma abordagem mais analítico-descritiva. É apenas no âmbito
das ações políticas e das ações educacionais que está em jogo um processo
interventivo sobre o ser do próprio homem, onde o aspecto normativo não é apenas
o nomotético mas também um aspecto orientador, intencionalizador. A
fenomenalidade apreensível do agir político e educacional dos homens fica
profundamente marcado pela construtividade e pela historicidade da prática humana,
e como tal, escapa da normatividade nomotética e de qualquer outra forma de
necessidade, seja ela lógica, biológica, física ou mesmo social, se tomado esta
último aspecto como elemento de pura objetividade (p. 132).

Dessa forma, ao se pensar a educação, faz-se mister entendê-la como prática socialhistórica intencional, de sujeitos dotados de potencial liberdade, que podem assim interferir, tanto positiva como negativamente, no processo educativo. Pode-se conhecer e fazer ciência com relação aos homens, mas essa ciência não abarca a totalidade e a complexidade dos fenômenos do humano e, menos ainda, tudo o que se refere à sua imaginação radical e a sua criatividade. Sobre estas, a ciência não tem nem a primeira e nem a última palavra.

Nesse sentido, as ciências humanas, que se debruçam sobre o objeto da educação, produzem conhecimento, utilizando seus recursos teórico-metodológicos que permitem conhecer o humano em seus diferentes processos, mas não a sua totalidade e complexidade como seres livres e criadores. Conhecimentos são também produtos que devem ser tomados como provisórios, pois a própria ciência é um processo que tanto pode confirmá-los, como superá-los ou negá-los. 
A produção de conhecimento na área das ciências humanas, em especial, ao tomar como objetos o sujeito e o processo educativo, tem-se configurado como atribuição específica dos pesquisadores da educação. Tal produção é socializada nos cursos de formação de educadores, na produção editorial e em eventos da área educacional. Daí, a interrogação: têm os educadores, no seu cotidiano, acesso a essa produção? Como selecioná-la? Que critérios utilizam para adotá-la como referência?

É nesse sentido que Severino (2000a) distinguiu “[...] entre o conhecimento sobre a educação produzido pelas ciências humanas que dela tratam, e um possível conhecimento intrinsecamente produzido no campo específico da própria educação [...]” (p. 133), o que demonstra uma dicotomia entre pesquisadores e educadores e faz com que o "[...] possível conhecimento produzido no campo específico da própria educação [...]" só tenha validade após o crivo dos pesquisadores. Daí, questiona-se: produzem os educadores conhecimento educacional? Refletem eles sobre sua própria prática? Ou são objeto de pesquisa dos experts da educação?

Pensar, então, a relação das ciências da educação com essa prática social - a educação:

De forma clara, não se deve esperar das ciências da educação aquilo que elas não podem dar, isto é, a elaboração de uma pedagogia segura de si mesma, segura de seus fundamentos, segura da ação a ser realizada, do gesto a ser feito, das palavras a serem ditas ou das finalidades a serem perseguidas. Tal projeto, a nosso ver, é irrealizável, pelo fato de que uma classe de 25 ou 30 alunos comporta dimensões em tensão, que ela constitui um conjunto singular que evolui no tempo, que esse conjunto não é hoje exatamente aquilo que era ontem em o que será amanhã, e pelo fato de que a ciência não poderia prescrever aquilo que contribui a descrever. Esse conjunto resiste à generalização científica, que certamente não é inútil, mas que não permite ao professor determinar com certeza o que convém fazer nessa ou naquela circunstância, o que será a sala de aula no instante seguinte, amanhã ou na semana que vem.

Dia após dia, o professor deve se adaptar a uma situação sempre nova, negociar com a complexidade do real, encarar novos desafios e realidades inéditas, "e essa adaptação supõe uma faculdade de julgar que só se aperfeiçoa com a experiência e sua elaboração em forma de uma reflexão pessoal" (CANIVEZ apud GAUTHIER et al., 1998, p. 359-360).

Assim, o cientismo se entranhou na sociedade capitalista, inclusive na educação, difundido pela ideia de que a ciência tudo pode e de que só é válido o que foi submetido a procedimentos científicos. Mas, por ser a educação uma prática social, é inconcebível pensar que a ciência poderia prescrever como ela deveria ser! Entendida assim a educação, qualquer tentativa de prescrição científica choca-se com o que há, em nós, de intrinsecamente humano - nossa psique, nossa história pessoal, nossa liberdade. Dessa forma, há fatos referentes aos humanos que a ciência pode conhecer, e eles se encontram apenas na esfera dos fenômenos físicos, químicos e biológicos. Os fenômenos da psique estão ainda a serem explorados, e o 
que deles se conhece não pode ser generalizado para prever-se ou prescrever-se na área da educação. Na educação, o que se pode e o que se deseja é a construção, por parte de quem educa, seja o pedagogo seja o professor, de uma reflexão sobre a própria prática, que lhe permita julgar as situações cotidianas e decidir sobre elas, com máximo de coerência e justiça. 


\section{A DISCIPLINA FILOSOFIA DA EDUCAÇÃO}

Eis porque conceber filosoficamente a educação é, antes de mais nada, entendê-la como terreno de permanente questionamento, de interrogação aberta. É assim que a filosofia investe a educação e não oferecendo um "menu” de concepções a serem escolhidas como nosso prato feito educacional.

Valle

\subsection{A institucionalização da disciplina de Filosofia da Educação no Brasil}

Em São Paulo, em fevereiro de 1931, o Decreto Estadual no 4888 reforma a Escola Normal da Praça (Caetano de Campos), transformando-a em Instituto Pedagógico, onde se cria o curso de aperfeiçoamento para preparação técnica de inspetores, delegados de ensino, diretores de estabelecimentos e professores do curso normal. Em 1933, são promulgados os Decretos $n^{\text {os }} 5.846$ e 5.844, que transformam o Instituto Pedagógico em Instituto da Educação e institui o Código da Educação. No Instituto de Educação, cria-se uma nova seção do curso de aperfeiçoamento - a Escola de Professores - destinada à formação pedagógica dos candidatos ao magistério secundário. O currículo de formação de professores primários distribuía-se em três seções: $1 .{ }^{a}$ Seção - Educação: psicologia, pedagogia, prática de ensino, história da educação; 2. ${ }^{a}$ Seção - Biologia aplicada à educação: fisiologia e higiene da criança, estudo do crescimento da criança, higiene da escola; 3. ${ }^{a}$ Seção - Sociologia: fundamentos da sociologia, sociologia educacional e investigações sociais em nosso meio.

A disciplina Filosofia da Educação institui-se no Brasil em 1933, quando da primeira escola de nível superior para formação do professor, o Instituto de Educação, que, em 1934, é incorporado à Universidade de São Paulo. A partir desta data, juntamente com a Faculdade de Filosofia, Ciências e Letras (FFCL), responsabilizar-se-á, na USP, pela formação de professores. É, portanto, no Instituto de Educação de São Paulo, criado pela reforma educacional de Fernando Azevedo em 1933, responsável pela formação de professores de nível superior, que a disciplina Filosofia da Educação se apresenta.

Segundo Evangelista (2001), inicialmente, nos currículos dos cursos de Administradores Escolares constava a disciplina Filosofia da Educação; nos de Formação do Professor Primário e de Formação do Professor Secundário, registrava-se a disciplina História e Filosofia da Educação. A partir de abril de 1935, com o Regulamento do Instituto de Educação da Universidade de São Paulo (IEUSP), a disciplina Filosofia da Educação foi retirada do curso de Administradores Escolares; a disciplina História e Filosofia da Educação 
permaneceu nos cursos de Formação de Professor Primário e de Formação do Professor Secundário, que se iniciaram em 1936. Ressalta-se ainda, segundo a autora, que era "[...] oferecida na FFCL a formação específica e no IEUSP, a pedagógica, o que implicava uma separação entre a formação no plano dos conteúdos do ensino, reduzida a formação pedagógica à manipulação dos meios de ensinar" (p. 253).

Assim, a institucionalização da disciplina Filosofia da Educação se dá na Universidade de São Paulo, nos currículos dos cursos de Administradores Escolares, de Formação de Professor Primário e de Formação do Professor Secundário, respectivamente, com as denominações de Filosofia da Educação, e de História e Filosofia da Educação, no segundo e no terceiro.

Para Teixeira (1969) e Lourenço Filho (2001), a primeira instituição a prover a formação do magistério, em nível superior ou universitário, foi a Escola de Professores do Instituto de Educação do Rio de Janeiro, ex-Distrito Federal, pelo Decreto no 3.810, de 19 de março de 1932, o qual é incorporado à Universidade do Distrito Federal, criada pelo Decreto n. ${ }^{0 .} 5.513$, de 4 de abril de 1935. O Instituto de Educação do Rio de Janeiro era constituído por quatro Escolas: a de Professores, a Secundária, a Primária e o Jardim-de-infância, sendo estas três últimas estabelecimentos de experimentação, demonstração e prática de ensino. Para ter acesso à Escola de Professores, era exigido o certificado de conclusão do ciclo fundamental, com duração de cinco anos, e aprovação do ciclo complementar, o qual corresponderia a um sexto ano do curso secundário, ambos na Escola Secundária do Instituto. O ciclo complementar compreendia as seguintes disciplinas: Literatura, Inglês ou Alemão, Fisiologia, Psicologia Geral, Estatística Aplicada à Educação, História da Filosofia, Sociologia Geral, Desenho e Educação Física. A Escola de Professores foi instituída em 10 Seções, que se responsabilizavam pelos diferentes cursos de que fosse encarregada. As Seções eram: I Biologia Educacional e Higiene; II - História e Filosofia da Educação, Educação Comparada e Administração Escolar; III - Psicologia Educacional e Sociologia Educacional; IV Matérias de Ensino Primário; V - Matérias de Ensino Secundário; VI - Desenho e Artes Aplicadas; VII - Música; VIII - Educação Física, Recreação e Jogos; IX - Prática de Ensino Primário; X - Prática de Ensino Secundário. As Seções II e III compunham, até 1934, a Seção Educação e as Seções IV e V, a de Matérias de Ensino.

O curso de formação do magistério primário era feito em dois anos, e cada ano letivo se dividia em três períodos, de um trimestre cada um.

No primeiro ano do curso, nos três períodos, cursavam-se os fundamentos, na seguinte sucessão de cursos: 1. Biologia Educacional, 2. Psicologia Educacional; 3. Sociologia 
Educacional. Paralelamente, por todo o ano, estendiam-se os cursos de Historia da Educação, Artes e Educação Física, e ainda, no primeiro trimestre, era ministrado um curso de Introdução ao Ensino.

No segundo ano, de aplicação, predominava a Prática de Ensino em suas diversas etapas: observação, participação e direção de classe e todas as demais matérias que a elas se prendiam.

Nos dois últimos trimestres do primeiro ano e no primeiro do segundo ano, eram ministrados os estudos intermediários, que compreendiam a Seção de Matérias do Ensino Primário - Cálculo, Leitura e Linguagem, Literatura Infantil, Ciências Naturais e Estudos Sociais - com o objetivo de permitir "[...] o exame dos princípios informadores da técnica, em conjunto com as condições da própria realidade prática" (LOURENÇO FILHO, 2001, p. 26).

Para Tanuri (2000), o curso de formação do professor primário compunha-se das seguintes disciplinas:

1. ${ }^{\circ}$ ano: biologia educacional, psicologia educacional, sociologia educacional, história da educação, música, desenho e educação física, recreação e jogos;

2. ${ }^{\circ}$ ano: introdução ao ensino - princípios e técnicas, matérias de ensino (cálculo, leitura e linguagem, literatura infantil, estudos sociais, ciências naturais) e prática de ensino (observação, experimentação e participação). (p. 73).

Pergunta-se, pois: o que é da Filosofia da Educação na Escola de Professores?

Tomando de Dewey os conceitos de Filosofia e de Filosofia da Educação, respectivamente, “[...] a investigação e a inquirição sobre o que exige de nós o conjunto de conhecimentos atualmente existentes ou o conjunto de conhecimentos que temos" (p. 145-6) e “[...] estudo dos problemas que se referem à formação dos melhores hábitos mentais e morais em relação às dificuldades da vida social contemporânea” (p. 148), Anísio Teixeira (1971), que pensa "[...] existir uma ciência da moral e da conduta humana." (p. 107), propõe como tarefa da escola: "Em vez de bacharéis, queremos pedir à escola a formação em série, de pequeninos Sócrates" (p. 104).

Mas, como formar "pequeninos Sócrates", isso é, filósofos-cidadãos, se a tarefa da escola na promoção da reconstrução social visa o controle da "[...] Revolução, antes que a façam na rua"? Para Anísio Teixeira, não há aí contradição. O filósofo-cidadão pensa a rua fora da rua, pensa a pólis fora da pólis, podendo substituir a prática política que aí se deveria desenvolver: "Dêem-lhes os elementos da cultura, de estudo e de recurso, e esses exércitos irão tentar a renovação da humanidade, a grande aventura da democracia [...]” (TEIXEIRA, 1971, p. 104-105). 
Mas seria possível pensar e viver a democracia, sem a participação de todos os cidadãos? Se a democracia é "[...] o regime explicitamente fundado sobre a doxa, a opinião, a confrontação das opiniões, a formação de uma opinião comum.” (CASTORIADIS, 1992, p. 114) - regime este que Sócrates não cessou de questionar, afirmando e mostrando que todas as doxai são errôneas - como pensar a formação de pequeninos Sócrates, em uma reconstrução social calcada na ciência e em uma "[...] filosofia de hipóteses e soluções provisórias" (TEIXEIRA, 1971, p. 148)?

A Filosofia da Educação, na Escola de Professores, é compreendida:

[...] como coroamento de todos os estudos, no período final, são levados os alunosmestres ao debate das questões de Filosofia da Educação. Este curso, de sistematização e não de dogmatização, só aparece, assim, como conviria, depois de terem os estudantes o necessário cabedal de fatos e informações e de viva experiência de ensino (LOURENÇO FILHO, 2001, p. 25).

A compreensão de Anísio Teixeira da Filosofia como filosofia de vida; como filosofias individuais, construídas a partir da experiência; ou como produções filosóficas de uma época, de uma cultura, consubstanciadas em programa de ação e de conduta reflete na Filosofia da Educação na Escola de Professores, ministrada no último período, como curso de debate e sistematização sobre fatos, informações e experiência de ensino. Essa postura identifica Filosofia e Cultura e perde a especificidade do trabalho filosófico. Assim, a Filosofia da Educação na Escola de Professores pode ser compreendida como um momento de debates e sistematização de opiniões. Confirma tal posicionamento a postura de Anísio, em relação aos sistemas filosóficos existentes: criações pedantes de gabinete.

Em 1935, é instalada também a Universidade do Distrito Federal (UDF), universidade municipal no Governo do Sr. Pedro Ernesto, e Anísio Teixeira dirigia a Instrução Pública. Nesta, são ministrados os cursos de filosofia, ciências, letras, economia, política, pedagogia etc.

O pronunciamento de Paschoal Leme, na III Conferência Brasileira de Educação, em Niterói, no período de 12 a 15 de outubro de 1984, citado por Fávero (1989), evidencia a importância da experiência da UDF:

Inspirado, sem dúvida, nos aspectos mais positivos da educação norte-americana, que estudara diretamente no curso superior que fizera na Universidade de Colúmbia, em Nova Iorque, Anísio pôde criar no antigo Distrito Federal o primeiro verdadeiro sistema de educação, integrado e completo que se estendia do pré-escolar modernizado em suas finalidades, seguido, sem solução de continuidade, do curso primário de cinco anos, extraordinariamente enriquecido com a prática das chamadas artes industriais, da música, do canto orfeônico, entregue ao gênio de Villa-Lobos, da educação física, recreação e jogos, prosseguindo com uma educação secundária, unificada em seus aspectos humanísticos e de formação profissional e 
culminando com a cúpula do ensino superior, representado por aquela Universidade do Distrito Federal, sui generis, a UDF de tão saudosa memória (p. 21-22).

É efêmera a existência da Escola de Educação do Instituto de Educação da UDF, pois o Decreto-lei n. ${ }^{\circ} 1.063$, de 20 de janeiro de 1939, que dispõe a transferência de estabelecimentos de ensino da Universidade do Distrito Federal para a Universidade do Brasil, o exclui, bem como os cursos de formação de professores, de orientadores do ensino primário, de administradores escolares e de aperfeiçoamento da Faculdade de Educação, conforme parágrafo único do artigo primeiro. E a atitude que se tem para com a Filosofia da Educação no Instituto de Educação do Rio de Janeiro leva a considerar que esta se instituiu em São Paulo.

Para Tomazetti (2001):

\begin{abstract}
A aceitação da necessidade de uma cultura filosófica e científica (ciências da educação), no conjunto da formação do professor secundário, tornara-se consenso mundial nos anos 30 , sustentada pelas idéias reformadoras em educação. No texto, $A$ formação do professor secundário, publicado nos Arquivos do Instituto de Educação de São Paulo, em 1937, eram apresentados os resultados do inquérito realizado pelo Bureau International d' Education acerca dessa questão. (p. 447).
\end{abstract}

Ainda no mesmo artigo, intitulado Filosofia da Educação e formação de professores em algumas universidades brasileiras entre os anos 40 e os anos 60, a autora apresenta, em nota de rodapé, o resultado da consulta a 56 países, onde em 46 deles, como Alemanha, Argentina, Austrália, Áustria, Bélgica, Brasil (São Paulo), Bulgária, Canadá, Chile, Espanha, Estônia, China, Cuba, Dantzig, Dinamarca, Escócia, Estados Unidos, Egito, Finlândia, Grécia, Guatemala, Holanda, Hungria, Índia, Inglaterra, Irã, Iraque, Irlanda (livre e do norte), Japão, Letônia, Lituânia, Luxemburgo, México, Noruega, Nova Zelândia, Panamá, Polônia, Portugal, Romênia, Suíça, Checoslováquia, Turquia, URSS, Iugoslávia, se efetivava um preparo nas ciências fundamentais da educação: Biologia, Psicologia, Higiene, Sociologia, História e Filosofia da Educação, Organização do Ensino e Educação Comparada.

É, portanto, no Instituto de Educação, criado por Fernando de Azevedo em 1933 e incorporado à Universidade de São Paulo em 1934, que se dá a instituição da disciplina Filosofia da Educação no Brasil.

Em nível nacional, ela é tributária da criação das Faculdades de Filosofia, Ciências e Letras, estabelecida pelo Estatuto da Universidade Brasileira de 1931 - Decreto n. ${ }^{\circ} 19.851$, de 11 de abril de 1931 - em pleno governo provisório de Getúlio Vargas, que previa:

Art. $5 .^{\circ}$ - A constituição de uma universidade brasileira deverá atender às seguintes exigências: 
I. congregar em unidade universitária pelo menos três dos seguintes institutos do ensino superior: Faculdade de Direito, Faculdade de Medicina, Escola de Engenharia e Faculdade de Educação, Ciências e Letras (BRASIL, 1931, p. 1).

Ainda na mesma data, 11 de abril de 1931, é também publicado o Decreto de n. ${ }^{\circ}$ 19.852, que definiu os objetivos da Faculdade de Educação:

\begin{abstract}
Uma Faculdade de Educação, de Ciências e Letras para ministrar cursos abrangendo as diversas disciplinas do nível superior, tendo como finalidade melhorar a cultura nacional, no domínio das ciências teóricas, promover pesquisas práticas e originais, proporcionar a necessária formação especializada aos professores e contribuir a organização e aperfeiçoamento do ensino técnico e científico, visando atender ao interesse das diferentes atividades do País (LAUWERYS, 1969, p. 306).
\end{abstract}

Ao analisar a exposição de motivos do ministro Francisco Campos, que previa que o papel das faculdades de educação seria imprimir à universidade:

[...] caráter propriamente universitário, permitindo que a vida universitária transcenda aos limites do interesse puramente profissional, abrangendo, em todos os seus aspectos, os altos e autênticos valores de cultura, que à Universidade conferem o caráter e atributo que a definem e a individuam (FAVERO, 1989).

ressalta-se, que

[...] a função de investigação e de formação de professores, competente à Faculdade de Educação, Ciências e Letras, é esquecida no plano federal até 1939 (p. 15).

Portanto, é em 1939, com a criação da Faculdade Nacional de Filosofia da Universidade do Brasil, mediante o decreto-lei ${ }^{\circ}$ 1.190, de 04 de abril de 1939, em que se institui o curso de Pedagogia, que o governo federal define a obrigatoriedade do ensino de Filosofia da Educação.

Mas, instituída como disciplina, a Filosofia da Educação possui caráter de prática reflexiva?

\title{
4.2 A identidade da disciplina Filosofia da Educação: uma construção instituída
}

Ao constituir uma prática social, a educação se faz inerente a toda realidade socialhistórica, desenvolve-se sempre condicionada às significações imaginárias, com finalidades explícitas ou implícitas de autoconservação do instituído, embora conviva com a possibilidade de ruptura pela interrogação do instituído e pela criação do novo, seja na prática social política ou educativa, seja pela instituição de novas significações sociais. Assim, a educação é instituída e instituinte, isto é, autoconservação e autoperpetuação das significações 
imaginárias do social-histórico, mas pode ser também possibilidade de um futuro diferente, se os indivíduos o quiserem e o fizerem ser. Essa possibilidade pode concretizar-se em nível coletivo, como interrogação: no exercício político, na participação de todos na discussão e deliberação dos negócios comuns - res publica - e no exercício da educação. Ressalta-se, todavia, que o que é o contexto social-histórico é o que potencialmente seus membros serão; se ele for justo e democrático, seus membros tenderão a sê-lo, pela socialização; se ele for injusto e autoritário, assim se tornarão seus membros e vice-versa.

Ao longo da história da humanidade, nos diversos social-históricos, embora os filósofos tenham produzido ideias para responder às perguntas filosóficas: o que é educação? Com que finalidade se educa? - elas só vieram a se instituir como uma disciplina escolar no século XX. E o que é Filosofia da Educação? O que ela é como disciplina curricular? Qual o seu espaço?

Não é decerto possível pensar a identidade da disciplina de Filosofia da Educação sem se remeter à história da Filosofia e às elaborações que os filósofos produziram sobre educação. A relação entre Filosofia e Educação remonta à antiguidade grega e é instituída com a criação da própria Filosofia, que se refere à preocupação com a formação do homem paidéia. Tributária da Filosofia, a disciplina Filosofia da Educação também está instituída, faz parte do currículo de formação dos pedagogos, desde a criação do seu curso, e presentifica-se também em alguns cursos de licenciatura.

Interrogar-se sobre o que é Filosofia da Educação pressupõe pensar na sua identidade como criação da realidade social-histórica, designando algo ou alguém e o que lhe é próprio.

Instituída pelo social-histórico, pelo coletivo de atores que atuaram na educação, a disciplina Filosofia da Educação tem sido objeto de questionamentos sobre sua identidade e sobre seus conteúdos. Essas interrogações, ao que historicamente foi instituído, podem e devem ser propositura de outra identidade, de outros conteúdos, que se instituirá no socialhistórico, se ele os assimilar.

Assim, podem-se compreender os trabalhos de Albuquerque (1996 e 2002), Quillici Neto (2001), Tomazetti (2000a) e Pereira Silva (2000).

Albuquerque (1996), em sua dissertação: Filosofia da Educação: uma disciplina entre a dispersão de conteúdos e a busca de uma identidade, ao utilizar-se das teorias da Nova Sociologia da Educação, da Sociologia do Currículo e dos textos de filósofos da educação brasileira, investigou 30 Programas de Filosofia da Educação de 10 universidades públicas, sendo duas de cada região do país (Norte, Nordeste, Centro-Oeste, Sudeste e Sul), nos anos de 
1994 e 1995, 18 curriculum vitae dos professores que ministravam a disciplina e entrevistou cinco intelectuais afetos à área de Filosofia da Educação, com os objetivos de:

[...] analisar o que dizem os teóricos desta disciplina acerca do seu objeto de investigação; analisar a seleção dos conteúdos de Filosofia da Educação nos cursos de Pedagogia de diferentes instituições de ensino superior no Brasil; verificar que literatura tem orientado o seu ensino e analisar a formação acadêmica do professor de Filosofia da Educação (p. 17).

Ao relatar a criação e a organização do curso de Pedagogia, em uma breve retrospectiva histórica, discute-se a natureza da disciplina Filosofia da Educação nas legislações - Decreto 1.190/39, Parecer 251/62, Parecer 292/62, Parecer 252/62, Parecer 632/69 - que orientaram o curso de Pedagogia até 2006, tomando como ponto de partida a Lei $5.540 / 68$.

Levantam-se, então, questões acerca da identidade da disciplina Filosofia da Educação - "Como a disciplina Filosofia da Educação é concebida por teóricos da Educação no Brasil? Qual seu objeto de investigação?”. Albuquerque (1996) buscou nas literaturas que a discutem, “[...] as principais contribuições acerca da disciplina Filosofia da Educação, no que diz respeito ao seu objeto de estudo, aos conteúdos que lhe são específicos e ao sentido mesmo que esta disciplina tem enquanto tal, para além do campo normativo" (p. 49).

Ao trabalhar com os autores Sucupira (1969), Luckesi (1990), Saviani (1984), Martins (1993), Lara (1987), Von Zuben (1990), Gadotti (1978 e 1991) e Severino (1990 e 1993), a autora apontou as seguintes conclusões a respeito da identidade da disciplina:

\footnotetext{
[...] o problema da indefinição do objeto da disciplina Filosofia da Educação, relaciona-se àquilo que já foi falado por Sucupira (Parecer 632/69) que diz respeito ao fato de ser ela uma disciplina de caráter aplicado, no sentido de ser ela uma disciplina que se aplica ao objeto Educação e, portanto, que oscila entre dois campos do saber (o filosófico e o educacional) os quais, por sua vez, também não possuem um campo epistemológico rigidamente definido (p. 51-52).

Finalmente, o que basicamente tem caracterizado os programas de Filosofia da Educação analisados é o que denominei de dispersão. Em algumas universidades esta disciplina tende muito mais para a Filosofia, em outras para a Sociologia, e até mesmo a partir da junção de temas da Filosofia com a Psicologia. Além disso, há a dispersão entre as próprias temáticas de um mesmo programa as quais são selecionadas a partir dos 16 grandes temas anteriormente descritos. Temas estes que nem sempre apresentam uma articulação entre filosofia e educação (p. 115).
}

No que concerne às conclusões da autora, de que a indeterminação de uma configuração precisa do objeto da disciplina Filosofia da Educação se dá pelo fato de ser uma disciplina recente e cujos investimentos, em nível de produção acadêmica, também o são, pensa-se que não há indefinição no que diz respeito ao seu objeto. Ele é a educação e seus problemas, e perspectiva filosófica de análise. 
Além disso, diferente do que apontou Sucupira, no Parecer 632/69, acredita-se que a disciplina Filosofia da Educação não seja aplicada à educação. Ao longo da história da educação, em geral, embora as elaborações teóricas dos filósofos tenham sido apropriadas pelos professores de filosofia da educação, para ensinar sua concepção de educação, de homem, de sociedade, de moral etc., estas não eram tomadas para compreender o socialhistórico na atualidade. Assim, reproduzir a História da Filosofia e da Filosofia da Educação restringia a disciplina de Filosofia da Educação ao estudo do passado, o que inviabilizava uma potencial reflexão sobre os problemas da educação. A Filosofia da Educação é uma disciplina teórica que se utiliza para interrogar a educação, para elucidá-la. Ela não pode ser compreendida como um passeio ao que os grandes filósofos produziram e nem ser tomada dogmaticamente. Eles são importantes e fundamentais, se forem tomados como possibilidade para o esclarecimento dos problemas atuais da educação.

Ao verificar as diferentes formas de organizar os programas de Filosofia da Educação, bem como os diferenciados assuntos propostos para serem ensinados, Albuquerque (1996), questionou se a "[...] pluralidade de pontos de vista [...] é desejável para a configuração da identidade da disciplina” ou se se evidencia sua dispersividade. Pensa-se que ela é decorrente da riqueza que apresenta a história da filosofia da educação, da autonomia das instituições/professores na construção de seus programas e de assuntos e na formação do professor de Filosofia da Educação. A própria autora apontou:

A questão da formação do professor de Filosofia da Educação parece ser realmente
um fator que influencia tanto na forma como a literatura conduz a discussão desta
disciplina, como também nos conteúdos que propõe para serem ensinados. Em
outras palavras, a seleção dos conteúdos nesta disciplina parece ser definida muito
em função da "familiaridade" que o professor tem com o seu curso de origem
(ALBUQUERQUE, 1996, p. 56).

Assim, a formação do professor de Filosofia da Educação parece ser um dos fatores relevantes na constituição dos programas e assuntos da disciplina. Se sua formação for em filosofia, tenderá a privilegiar os conteúdos filosóficos em detrimento da educação; se for em pedagogia, tenderá a privilegiar os assuntos pedagógicos, sem analisá-los em perspectiva filosófica.

Nesse sentido, pode-se pensar que a formação do professor de Filosofia da Educação, compreendendo sua graduação e pós-graduação, tem funcionado para encarcerá-lo num fechamento cognitivo, isto é, para constituir verdade aquilo que internalizou e que, doravante, utilizará em suas atividades profissionais. Pode-se, portanto, indagar: quem é o melhor professor da disciplina de Filosofia da Educação? O formado em Filosofia ou em Pedagogia? 
Ou ainda, talvez com maior acerto, indagar sobre que tipo de formação se tem efetivado nos cursos de Filosofia e de Pedagogia, que não se consegue construir um sentido para a atividade educativa e nem possibilita a construção da atitude de interrogação sobre o instituído?

Pensa-se que o problema reside nos cursos de formação. Mas como proceder uma ruptura, se os professores de Filosofia da Educação estão fechados cognitivamente? Uma das saídas seria, talvez, uma padronização do que deveria ser um programa de Filosofia da Educação e, por um ato administrativo, tentar implementá-lo? Mas isso não seria um ataque frontal à liberdade e autonomia do professor? Este poderia assumir o programa oficialmente e, na sua efetivação, trabalhar outros conteúdos? Outra saída seria que instituições, como ANPED e ANFOPE, buscassem a construção de um programa que se tentaria socializar nacionalmente. Mas há divergências entre os próprios membros dessas instituições. Tal situação é a mesma que enfrenta a construção de um programa de ensino de Filosofia, em nível médio do ensino.

Assim, a única saída é que os professores de Filosofia da Educação pensem, pesquisem e reflitam sua própria prática e tentem socializá-la em eventos, para que no diálogo consigam construir uma proposta que venha a ser consenso e que, por meio da adesão de outros professores, venha a instituir-se nacionalmente.

Em sua pesquisa - $O$ ensino da Filosofia da Educação no Brasil: uma análise dos programas de ensino de Filosofia da Educação dos cursos de Pedagogia do Estado de São Paulo - 1988-1998, Quillici Neto (2001), teve o objetivo de "[...] elucidar a prática de Filosofia da Educação nas faculdades de Pedagogia do Estado de São Paulo” (p. 1) e tomou como objeto de análise os objetivos, os conteúdos e as bibliografias de 172 programas da disciplina, de 12 faculdades, e de um curso virtual de Filosofia da Educação para "[...] descobrir quais matrizes teóricas e metodológicas norteiam a prática de ensino de Filosofia da Educação no Brasil” (p. 1).

No que interessa à problemática pesquisada, algumas conclusões do autor remete a Saviani (1982), que apontou como problema da Filosofia da Educação, a “[...] tendência a se colocar a ênfase na primeira palavra da locução - uma ênfase seja na filosofia, (...) - e a segunda palavra - a educação - aparece como um apêndice, como uma mera conseqüência" (p. 32) ou vice-versa, o que leva a disciplina Filosofia da Educação a apresentar-se como História da Filosofia ou como análise de alguma temática educacional.

É o que apresentou Quillici Neto:

Percebemos em nossa pesquisa uma certa desarticulação entre os programas de Filosofia da Educação, pois os temas são muito variados e poucos professores tomam a educação como objeto principal de análise. Por um lado, os professores 
pensam a Filosofia da Educação como uma História da Filosofia e seu programa jamais toca no problema educacional. Por outro lado, há programas que trabalham uma temática educacional sem considerar a Filosofia como método de análise (p. 5).

Apoiando-se ainda em Saviani (1982), em sua proposta de três linhas básicas que assumem os programas de Filosofia de Educação, nota-se a postura eclética:

Diante da tentativa de explicitar as concepções que fundamentam o ensino de
Filosofia da Educação nos programas de ensino, nos deparamos com o desafio de se
levantar uma concepção de Filosofia da Educação. Ocorre que um mesmo programa
consegue trazer vários matizes teóricos, sem deixar explícita uma reflexão a partir de
uma visão de Filosofia. Os professores, na sua maioria, não demonstram uma
preocupação teórica que dê coesão ao seu programa. Decorre daí o caráter eclético
da Filosofia que se traduz numa postura não muito clara ou definida, prática comum
nos cursos de Pedagogia, onde num mesmo lugar cabem várias concepções (p. 88).

Na postura eclética dos programas dessa disciplina - "justaposição das diferentes correntes", "tanto no sentido diacrônico como em sentido sincrônico" (1982, p. 33), não se demonstra preocupação teórica, nem se explicita uma reflexão apoiada em uma concepção filosófica. Quillici Neto (2001) analisou a postura da historicidade introdutória, em que os programas são organizados por temas, o que inviabiliza a análise dos problemas educacionais:

\begin{abstract}
A postura introdutória parece, ainda, trazer uma problemática significativa para nossa análise, pois quando o professor opta pela mera historicidade introdutória, se ausenta da análise de uma problemática central na educação. Muitas vezes, falta uma linha que norteie seu programa e os temas são indicados de forma aleatória e descompromissada (p. 94).
\end{abstract}

As questões referentes à identidade da Filosofia da Educação - “[...] será que o ensino da Filosofia na formação do pedagogo enfrenta uma crise na sua identidade e no seu projeto?" (p. 97), apresentadas por Quillici Neto, apóiam-se na ideia de que esta disciplina tenha um programa voltado para a ideia de transformação da sociedade: "Os filósofos não fizeram mais que interpretar o mundo de forma diferente: trata-se porém, de modificá-lo" (MARX apud VASQUEZ, 1977, p. 161). Mas é papel do filósofo pensar o mundo, problematizá-lo, interpretá-lo, elucidá-lo. Para Castoriadis (1992), “O intelectual deve pretender ser cidadão como os outros, deve também pretender ser, de direito, porta-voz da universalidade e da objetividade. O intelectual só pode se manter nesse espaço, reconhecendo os limites do que sua suposta objetividade e universalidade lhe permite." (p. 118-119).

O aporte teórico, em que se apóia Quillici Neto - Vasquez, Kosik, Sanfelice, Saviani, Severino, Gadotti, Gramsci e outros -, denota uma perspectiva de filiação a uma concepção marxista, que marca sua análise. Sem invalidar as questões apontadas ao longo do trabalho, ressaltam-se três problemas no seu conteúdo: 
- O autor considerou a Filosofia como método formal de análise, e não como prática de interrogação dos problemas da educação.

- O segundo refere-se à forma como o autor se fecha em torno de sua filiação a uma concepção filosófica, risco já apontado por Saviani (1982), quando a adesão teórica impede o recoinhecimento de outras matrizes teóricas, limitando-lhes a lente para a visada do objeto educação. Tal postura pode tornar-se uma forma de interpretar, dogmaticamente, a realidade educacional, mas não de interrogar-se, sem limites, sobre ela.

- O terceiro problema refere-se ao pressuposto de uma disciplina com programa voltado para a transformação da sociedade. Ora, a realidade social-histórica é, como analisa Castoriadis, um para si, cujos atributos essenciais são "[...] a finalidade de autoconservação, autocentrismo e construção de um mundo próprio" (CASTORIADIS, 1992, p. 207). Assim, atribuir a uma disciplina teórica, obrigatória apenas para o curso de Pedagogia, a finalidade de transformar a sociedade é não somente desconhecer como se instituem as realidades que fazem ser a sociedade e suas instituições, mas igualmente desprezar a exigência que deve estar presente em todo projeto teórico, de reconhecer os limites de sua atuação.

O próprio Quillici Neto (2001) reconheceu:

Não somos ingênuos em pregar uma Filosofia da Educação fundada numa práxis, que irá transformar a sociedade brasileira de maneira rápida; pelo contrário, a própria História da Filosofia no Brasil, tem seus vícios, suas raízes, seus ideais, e muitos deles fundados em concepções que contradizem este nosso modo de pensar. Por isso, os filósofos da educação têm que ser pacientes e ao mesmo tempo buscar seu espaço e seu papel na educação (p. 110-111).

Tomazetti (2000a) propôs-se “[...] encontrar na história da educação e na história da constituição do campo educacional, elementos significativos para a compreensão da constituição e afirmação deste saber/disciplina denominado filosofia da educação", buscando responder à questão:

Que características definiram o saber filosófico sobre educação, primeiramente um saber fundamentador da Pedagogia e, posteriormente, como uma disciplina de formação pedagógica, ao lado das ciências da educação, no ensino normal até os anos 30 e nos cursos de formação de professores secundários, entre os anos 40 e 60 ? (p. i)

A autora elegeu como objeto, os programas de ensino ministrados nas aulas de Filosofia da Educação de algumas escolas normais e de universidades, como Universidade de São Paulo (USP), Universidade do Brasil (UB), Universidade Federal do Rio Grande do Sul 
(UFRGS) e Pontifícia Universidade Católica do Rio Grande do Sul (PUC-RS), entre os anos 40 e 60.

Ao discorrer sobre a formação do homem e sobre a condição do filósofo-preceptor, a autora chamou atenção para a importância do papel do filósofo, que, mais tarde, teria a responsabilidade institucional (professor de Filosofia da Educação) de "[...] pensar os rumos da educação, por definir os fins e os valores educacionais, enfim, por construir uma compreensão totalizadora da educação, capaz de nomear o sentido da educação" (TOMAZETTI, 2000a, p. 3). Diferentemente da autora, pensa-se que os rumos da educação, seus fins, seus valores e sentido devem conduzir à participação na construção do socialhistórico.

Ao discutir a institucionalização da disciplina Filosofia da Educação em algumas universidades brasileiras (anos 40-60), Tomazetti (2000a) analisou o modelo das Faculdades de Educação, Ciências e Letras, criado pelo Estatuto da Universidade Brasileira - decreto n. ${ }^{\circ}$ 19.851, de 11 de abril de 1931 - abrangendo o modelo pioneiro da USP, com a Faculdade de Filosofia, Ciências e Letras, em 1934, e o modelo imposto pela Faculdade Nacional de Filosofia (FNFi), da Universidade do Brasil (posteriormente, Universidade Federal do Rio de Janeiro), em 1937.

Analisando os programas de Filosofia da Educação, entre os anos 40 e 60, Tomazetti (2000a) afirma que:

[...] o tipo de trabalho era propriamente o de apresentação da história do pensamento educacional de autores considerados clássicos e, também, a partir da sistematização da história da filosofia em correntes como realismo, empirismo, idealismo, pragmatismo, materialismo, existencialismo, por exemplo, e a dedução de implicações educacionais.

A tradição do ensino de filosofia da educação, nos cursos de formação de professores, no Brasil, a partir deste estudo foi, portanto, aquela definida por Israel Scheffler de aplicação de doutrinas filosóficas puras, já prontas, ao campo educacional. O trabalho do professor ou filósofo da educação caracterizaria-se, então, como sendo, "o de tirar conseqüências, implicações de tais doutrinas." Desta forma, haveria tantas filosofias da educação quantas fossem as filosofias "puras" escolhidas como referenciais (p 151-154).

Assim, o trabalho de Tomazetti concluiu que a Filosofia da Educação muitas vezes se reduz à transmissão dos conteúdos prontos e acabados de autores clássicos - o que, sem dúvida, inviabilizava a interrogação filosófica da educação na atualidade e reforça a carência de identidade da disciplina que a autora também assinala. Apontou, ainda, a importância, as limitações e a possibilidade de conjugação do tratamento analítico dos conceitos educacionais e histórico-filosófico da educação, decorrentes de se pensar a Filosofia da Educação como uma disciplina teórica, a partir de duas referências: 
[...] como compreensão histórica (visão clássica) propõe o conhecimento, na história da filosofia, das idéias sobre educação e a partir disso realiza deduções e prescrições educacionais. A segunda referência é dada pela análise da linguagem educacional (TOMAZETTI, 2000a, p. 160).

Ainda que a autora não pretenda, em seu trabalho, definir qual seria a orientação a ser dada à disciplina, percebe-se, em sua argumentação, que a possibilidade de conjugação da compreensão histórica e da análise da linguagem educacional é a sua opção. Mas, ao se assumir essa postura em relação à Filosofia da Educação, observa-se ainda aqui a imputação à disciplina do papel de dedução e prescrição educacionais, e não de interrogação sobre a prática educativa, em vistas de sua elucidação. Compreende-se que a precariedade de apropriação cultural dos educandos faz com que o conhecimento da história da filosofia seja fundamental; mas não se pode reduzir a disciplina a apenas isso. Pois, a apropriação da história da filosofia da educação nada significará se não servir à construção pelos educandos de uma atitude de interrogação sobre a educação - pois esta será, no futuro, a sua prática. No que concerne à análise da linguagem educacional, "[...] análise dos conceitos que sustentam o discurso educacional, que acabaria por potencializar a resolução de problemas da prática educacional" (TOMAZETTI, 2000a, p. 160), sem pretender filiação à filosofia analítica, pensa-se ser uma atitude inerente a todos os educadores.

Mas, persiste ainda a interrogação:

Ainda hoje a filosofia da educação carece de uma identidade em termos de definição de conteúdos e objetivos, enquanto uma disciplina formadora de professores. Permanece ainda a indagação: Qual a tarefa da Filosofia da Educação nos cursos de formação de professores? (TOMAZETTI, 2000a, p. 158).

O trabalho de Pereira Silva (2000), intitulado A disciplina Filosofia da Educação no curso de Pedagogia: referências para o debate identitário, apoia-se em referenciais do materialismo histórico e dialético, de Nietzsche, do debate pós-estruturalista e pós-moderno, em intuições fenomenológicas de Heidegger, em contribuições da sociologia do currículo de Apple, Tomaz Tadeu da Silva, e em contribuições acerca da interdisciplinaridade de Japiassu, Fazenda e, ainda, Severino, Gadotti e Frigotto.

Ao tomar como problema o debate identitário da disciplina Filosofia da Educação, no curso de Pedagogia, Pereira Silva (2000) interroga-se: “[...] como seria uma proposta de conteúdos para a disciplina Filosofia da Educação, fiel às especificidades da interrogação filosófica, proposta essa que pudesse contribuir numa organização interdisciplinar do curso de Pedagogia elou que fosse tangenciada pela lógica desta organização?” (p. 27). 
Para esse autor, a realidade da construção da disciplina Filosofia da Educação se faz em razão da responsabilidade subjetiva dos professores. Ao apoiar-se na dissertação de mestrado de Albuquerque (1996), respaldada por sua pesquisa de campo e pela análise do currículo da disciplina nas universidades UFPA, FUFAM, UFC, UFBA, UFG, UFMS, UFMG, UFSC, UFRGS e USP, ele afirmou que:

[...] os profissionais dessa disciplina optam por este ou aquele conteúdo devido, a suas preferências pessoais, sua formação ou produção científica, sua maior familiaridade ou identificação com determinado conteúdo, ou mesmo devido ao desconhecimento em relação ao que seja Filosofia etc.. (p. 30).

A obra de Pereira Silva (2000) está estruturada em cinco capítulos.

No primeiro, apresentam-se características fundamentais para a constituição do seu conceito de Filosofia, quais sejam: a perspectiva da totalidade, a busca da realidade em si do objeto pesquisado, o espanto e o ruir da obviedade como fenômenos tipicamente filosóficos, a Filosofia como filha da cidade, o processo de constituição da cidade-estado grega, que foi possibilitado e possibilitou, pelo pensar filosófico e pela democracia, a superação da consciência heterônoma e a instituição da consciência autônoma, as raízes do afastamento da Filosofia em relação à cidade e, por fim, que a Filosofia da cidade é filosofia da práxis. Evidenciou, ao tratar das características, uma filiação ao referencial marxista.

No segundo capítulo, ele se interroga sobre o que é educar e, apoiando-se no referencial antropológico marxista, assim se posiciona:

[...] educar é empunhar esse desafio histórico da onilateralidade, em todas as dimensões, espaços e experiências da existência humana, sofrendo o constrangimento que as limitações materiais, políticas, sociais e culturais possam significar, mas indignando-se e lutando contra esse constrangimento. É objetivar a produção do homem (cidadão) onilateral na construção de uma sociedade e de indivíduos integrados e autônomos (PEREIRA SILVA, 2000, p. 86).

Embora diversas ações humanas possam ser educativas, o autor privilegiou o debate sobre a instituição escolar de nível fundamental e médio, que devem ser objeto da disciplina Filosofia da Educação e do curso de Pedagogia:

Quando problematizo a escola, viso às suas contradiçães, mas também e
especialmente às suas possibilidades. Deste modo, só consigo vislumbrar um projeto
de conteúdos para disciplina Filosofia da Educação que denuncie os conteúdos
ideológicos do currículo escolar e, paralelamente, aponte as lacunas e brechas
institucionais e curriculares que possibilitam uma visão crítica da realidade social,
por meio de uma aprendizagem significativa e uma metodologia interdisciplinar que
revelem a integralidade da condição humana (p. 91).

Ao apoiar-se em Saviani e Libâneo, ele pensa a Pedagogia como uma teoria geral da educação, que deve investigar a realidade educacional. A Pedagogia, então, apropriar-se-ia 
dos aportes teóricos das ciências da educação, objetivando investigar os saberes organizados e sistematizados curricularmente e suas metodologias. Isso lhe concederia uma perspectiva de totalidade do fenômeno pedagógico.

No capítulo três, abre-se uma discussão acerca do debate curricular, com contribuições, no campo curricular, do marxista Apple, quais sejam: o currículo oculto, os limites da categoria "classe social" e a relevância de outros divisores de força e poder, tais como etnia, raça, gênero e cultura, um currículo e um sistema de avaliação nacional, a superação da dicotomia processo ou conteúdo nos debates curriculares, um currículo interdisciplinar e as contribuições pós-modernas e pós-estruturalistas ao debate curricular.

No capítulo quatro, o autor descreve sete autores - Tiago Adão Lara, Antônio Joaquim Severino, Demerval Saviani, Bruno Pucci, Paulo Ghiraldelli, Moacir Gadotti, cujos textos são sobre $\mathrm{O}$ que é Filosofia da Educação e, ou, títulos que se identificam com a discussão identitária, e, ainda, Paulo Freire.

O capítulo cinco, intitulado A disciplina Filosofia da Educação, no curso de Pedagogia: referências para o debate identitário constitui o cerne da obra.

Para Pereira Silva (2000):

Minhas afirmações não significam que espero da Filosofia elaborar receitas, com
conteúdos absolutos, com verdades definitivas. Pelo contrário, a "resposta" que se
espera da Filosofia, por mais paradoxal que pareça, é muito mais um conjunto de
perguntas, um movimento eterno de problematização, explicitação do problema,
des-cobrimento da questão, possibilitação do espanto e da duvida.
Assim, entendo que se não seria próprio de uma Filosofia da Educação dar
respostas, tampouco se esperaria dela fugir ao compromisso de possibilitar e
contribuir no processo de produção de respostas, em sendo, como afirmou Saviani,
um "afrontamento, pelo homem, dos problemas que a realidade apresenta". Vale,
ainda, lembrar aquela afirmação de Apple, segundo a qual, simplesmente
fracassaremos se não ousarmos ir além da análise (p. 165).

Assim, o autor elaborou e propôs seis critérios para a identidade da disciplina Filosofia da Educação.

O primeiro critério é de que "[...] os temas desta disciplina devem contemplar os desafios educacionais sob a ótica da Filosofia, objetivando a formação do homem integral, onilateral" (p. 168). Pensa-se que o objetivo da formação do homem integral, onilateral, deve ser pensado como um projeto social-histórico, ou como projeto políticopedagógico da instituição ou do curso, uma vez que a lei maior da educação já define suas finalidades e objetivos da educação. Além disso, ressalta-se que uma disciplina, no conjunto das disciplinas que compõem a vida escolar dos educandos, pouco ou quase nada poderia fazer, se o contexto social-histórico já exerceu sobre o educando o seu infrapoder, socializando-o em significações sociais. Todavia, o autor tem razão quando afirma que a 
disciplina Filosofia da Educação deve ter como objetivo a formação do homem integral, onilateral, pois toda ação educativa escolar é uma ação intencional. O problema está em como concretizar tal objetivo, fazendo ruir a obviedade, que é característica da heteronomia.

O segundo critério é de que:

[...] deve-se privilegiar (sem excluir temáticas de outras instituições de ensino intencional) a escola, mais especificamente, no meu modo de entender a escola pública. Valorizar seu potencial contra-ideológico ou contra-hegemônico. Este será diretamente proporcional à competência técnica dos profissionais do ensino. Tratase de formar um pedagogo-cidadão, teórica e tecnicamente, competente tanto quanto consciente das condicionantes políticas que o formaram e que podem ser transformadas por ele (PEREIRA SILVA, 2000, p. 169).

Pensa-se, como Pereira Silva (2000), que se deve privilegiar a escola pública. Todavia, o potencial contra-ideológico ou contra-hegemônico não é real. À medida que a escola foi criada e consolidou-se como instituição, ela constitui um instrumento que auxilia o infrapoder do social-histórico na socialização da psique, para torná-la indivíduo. O que se tem nas escolas em geral, são profissionais educadores que, ao compreenderem a realidade, almejam outra sociedade e agem para concretizá-la ou para conseguir que outros possam aderir a ela. Segundo esse autor, o potencial contra-ideológico ou contra-hegemônico "[...] será diretamente proporcional à competência técnica dos professores do ensino" (p. 169). Discorda-se desse posicionamento, pois a competência técnica, por si só, não é garantia de uma contra-hegemonia. O que possibilita a competência técnica é o domínio do como fazer. Mas, as questões: o que é? por que é? o que fazer? e por que fazer?, que correspondem aos motivos, ao sentido e à finalidade, não são respondidas, o que implica que a competência técnica é um fazer mecânico. Além disso, esse autor coloca sobre os ombros dos professores a responsabilidade da contra-hegemonia, esquecendo-se do coletivo escolar e do coletivo anônimo.

O terceiro critério apontado é:

[...] de que forma a pergunta filosófica forja ou possibilita pensar a educação [...] problematizar a ação pedagógica do ponto de vista, ou da perspectiva da totalidade, buscando sua realidade em si; espantando-se e fazendo ruir as obviedades ideológicas ou significações hegemônicas. A recuperar o sentido da pergunta filosófica como pergunta problematizadora do sentido da educação em aderência à cidade e sua problemática. A possibilitar a superação da consciência heterônoma em direção à autonomia, enfim, uma filosofia da práxis pedagógica (PEREIRA SILVA, 2000, p. 169-170).

Concorda-se com o autor de que a pergunta filosófica possibilita pensar a educação. Mas a questão está em como estimular tanto o educador quanto os educandos a se interrogarem sobre a ela. Enquanto ambos pensarem que a educação constitui a verdade, não 
existirá interrogação. Assim, pensa-se que é necessário ao educador entrar em crise em relação ao que pensa ser a educação, para posteriormente, interrogar-se sobre ela. A crise coloca-se então, como o grande problema. Ela é, portanto, o primeiro passo, mas tanto pode constituir o ponto de partida para a construção da pergunta filosófica problematizadora da educação, como o momento de entrega ao conformismo generalizado.

Não se pode perder de vista que a crise abala o que se pensa sobre educação, e isto implica uma atitude filosófica de dizer não ao que se pensava, acreditava e sentia, para, posteriormente, interrogar-se sobre o que é, para que é e por que é. Nesse sentido, pode-se recuperar o sentido da pergunta filosófica como problematizadora do sentido da educação e sua relação com o social-histórico. Ao colocar em suspensão ou ao estranhar aquilo que estava internalizado em si, buscando substituí-lo por novas idéias e pensamentos, o educador pode tentar superar sua consciência heterônoma.

O quarto critério,

[...] lembra que o currículo oculto, muito mais do que o currículo oficial, está impregnado de fundamentos e práticas ideológicos que favorecem os interesses das classes e grupos dominantes [...].

É função da Filosofia da Educação des-cobrir o "currículo oculto". Atenta às contradições deste currículo, saberá se utilizar de sua positividade, e brechas, favorecendo questões étnicas, de raça, gênero, da cultura local e das minorias, ao mesmo tempo em que contempla os conteúdos considerados de nível nacional (PEREIRA SILVA, 2000, p. 170).

Pereira Silva (2000), apoiado nas ideias de Apple e Giroux sobre currículo e mais especificamente, sobre currículo oculto, que favorece aos interesses das classes e dos grupos hegemônicos, colocou como função da Filosofia da Educação o revelar deste currículo e a ocupação de brechas para favorecer as minorias, os excluídos e marginalizados. Interroga-se, contudo, se o papel de desvelar o currículo oculto não é papel de todas as disciplinas? É papel apenas da Filosofia da Educação?

O quinto critério "[...] diz respeito ao caráter interdisciplinar que deve orientar as ações pedagógicas no curso de Pedagogia":

Deste modo, uma sensibilidade interdisciplinar é de fundamental importância
na elaboração de uma proposta de conteúdos para a disciplina Filosofia da
Educação, uma vez que busca superar a cultura da fragmentação do saber
além dos interesses corporativos (sentido negativo), sejam do curso ou das
disciplinas. Num projeto interdisciplinar, a disciplina Filosofia da Educação
aproximará suas temáticas da totalidade (a vida cidadã integrada no cosmos)
(PEREIRA SILVA, 2000, p. 171).

Ora, se “[...] cada disciplina convertendo-se num pequeno feudo intelectual, cujo proprietário está vigilante contra toda intromissão em seu pequeno cercado e 
metodologicamente protegido contra inimigos de fora" (JAPIASSU apud PEREIRA SILVA, 2000, p. 125), a interdisciplinaridade coloca-se como inexequível. Se a interdisciplinaridade é, para Fazenda (1979), um problema de atitude e significa romper as fronteiras do conhecimento disciplinarizado e acolher o diferente, a perspectiva do outro, isto implica a ruptura do fechamento cognitivo em que cada um está mergulhado, bem como o despir-se de vaidades intelectuais, narcisismos, interesses políticos etc. Assim, o ponto de partida para uma ação pedagógica interdisciplinar implica atitude de abertura ao outro, à critica, ao debate, ao diálogo para uma construção coletiva. Não há, portanto, como falar e efetivar a interdisciplinaridade em uma disciplina.

Por último, apresenta como critério:

\begin{abstract}
a "urgência de um currículo que esteja sintonizado com a construção de um intelectual específico e não universal [...].

a disciplina Filosofia da Educação precisa tematizar criticamente as transformações históricas que acenam para uma sociedade tecnologicamente complexa, consumista, espontaneísta e sem vínculos históricos. Precisa problematizar filosoficamente as novas concepções de erro, verdade e desempenho, assim como objetivar a formação de intelectuais específicos, sensíveis as demandas educacionais locais. (PEREIRA SILVA, 2000, p. 172).
\end{abstract}

O autor propõe como objetivo da Filosofia da Educação, a formação de intelectuais específicos, sensíveis às demandas educacionais locais e, como objeto, a tematização crítica das transformações históricas da sociedade tecnologicamente complexa, consumista e sem vínculos históricos.

Pensa-se que o objetivo de formar intelectuais específicos, e não universais, é um equívoco. O que são intelectuais? Segundo Castoriadis (1992), eles são “[...] os que, qualquer que seja seu ofício, tentam ultrapassar a esfera de sua especialização e se interessam ativamente pelo que se passa na sociedade", isto é, "[...] aqueles que, pelo uso da palavra e pela formulação explícita de idéias gerais, puderam ou podem tentar influir na evolução da sua sociedade e no curso da história" (p. 113).

Castoriadis ainda apresenta três pontos fundamentais para compreensão do intelectual, quais sejam: os dois tipos de relação entre pensador e comunidade política, que se apresenta nas figuras do filósofo na cidade e o filósofo que pretende estar acima da cidade; “[...] a tendência que tomou conta dos filósofos, a partir de certa fase histórica, para racionalizar o real, isto para legitimá-lo" e, por fim:

a questão levantada pela relação da crítica e da visão do filósofo-cidadão com o fato de que, num projeto de autonomia e democracia, a grande maioria dos homens e mulheres vivendo na sociedade são a fonte da criação, o depositário principal do imaginário instituidor; são esses mesmos homens e mulheres que devem tornar-se sujeitos ativos da política explícita (1992, p. 113). 
Ao tomar como objeto a disciplina Filosofia da Educação no curso de Pedagogia e ao definir como objetivo a formação do intelectual específico, Pereira Silva amplia, de forma inexequível, a tarefa da disciplina e se apresenta contraditório no que diz respeito tanto à especificidade do intelectual quanto ao seu quinto critério - a interdisciplinaridade.

Apresenta, ainda, uma proposta de conteúdo da disciplina Filosofia da Educação no curso de Pedagogia, a qual tem o tema geral: "Uma análise filosófica da teoria e da ação pedagógica problematizadora de conceitos e sentidos mais gerais (projeto, diretrizes e deliberações) até a ação pedagógica cotidiana das escolas, agências e instituições afins" (p.173) e seguinte objetivo geral:

Que esta disciplina favoreça uma reflexão realmente filosófica, buscando o sentido da ação pedagógica no interior e na lógica do sentido maior, que diz respeito à existência humana. Assim, que perceba esta ação numa perspectiva de totalidade, descobrindo a sua realidade, possibilitando a experiência do espanto e do ruir de certezas e obviedades pedagógicas rumo a uma consciência autônoma e uma maior aderência das temáticas com a problemática cotidiana das instituições de ensino intencional (p. 173).

A proposta está dividida em quatro partes. Na primeira, Pensando a si própria e as demais disciplinas, o objetivo específico é:

Que nesta primeira parte, a aluna/o possa ter acesso à textos clássicos da Filosofia, pelos quais ela (ele) possa identificar a (as) especificidade (s) da pergunta filosófica sobre a ação pedagógica, qual seja, a pergunta pelo sentido desta ação e os motivos do adoecimento da vontade de educar. Possa, também, experimentar nesta disciplina um diálogo com as demais disciplinas do curso de Pedagogia, seus estatutos epistemológicos e suas metodologias, na lógica de um curso pensado interdisciplinarmente (PEREIRA SILVA, 2000, p. 173).

E os conteúdos são: O que é a Filosofia; A Filosofia da Educação; O diálogo da Filosofia da Educação com as demais disciplinas do curso.

$\mathrm{Na}$ segunda parte, A Filosofia problematizando os fundamentos da educação e da ação pedagógica, o objetivo específico é que "[...] os temas privilegiadamente filosóficos possam ser problematizados" (PEREIRA SILVA, 2000, p. 174), e os conteúdos são os valores da educação e da ação pedagógica, a ética da ação pedagógica, o conhecimento, o aspecto político da ação pedagógica, a dimensão cosmológica da ação pedagógica, a dimensão estética da ação pedagógica e o sentido antropológico da ação pedagógica.

$\mathrm{Na}$ terceira parte, Pesquisando e transformando a ação pedagógica, do espaço universal ao local, o objetivo específico é:

Que nesta terceira parte, a aluna/o possa direcionar sua compreensão da especificidade da pergunta filosófica sobre a educação para a ação pedagógica de 
seu cotidiano. Que ela possa compreender o processo pedagógico, do qual faz parte e no qual pode e deve intervir, localmente (PEREIRA SILVA, 2000, p. 177).

Nesta terceira parte, o conteúdo é a realização de quatro pesquisas/análises: de projetos educacionais de agências internacionais, propostas nacionais do Ministério da Educação; de projetos, leis e programas, da Secretaria Estadual de Educação; e de projetos, leis e programas, da Secretaria Municipal de Educação, devendo ser problematizada na perspectiva filosófica, tendo como critérios a totalidade, a busca da realidade em si, o espanto e ruir da obviedade, a fidelidade à cidade, a passagem de uma consciência heterônoma a uma consciência autônoma e do critério da práxis, para fomentar "[...] debates reveladores de um eventual currículo oculto reprodutor dos interesses dominantes e articulações em favor de manifestações e intervenções políticas contra-reprodutoras dos alunos no conteúdo em questão.” (PEREIRA SILVA, 2000, p. 178).

Na quarta parte, Fechamento da disciplina e amarrações conclusivas, busca-se " [...] possibilitar respostas e alternativas às seguintes perguntas: quais razões da morte do sentido da educação? Quais os motivos do adoecimento da vontade de educar?”, objetivando “[...] contribuir na articulação em torno de um currículo oculto crítico, qual seja, sugestões curriculares e, ou, metodológicas alternativas e contra-ideológicas, para o cotidiano da escola brasileira” (PEREIRA SILVA, 2000, p. 180).

A proposta do autor compreende uma abordagem filosófica da educação, com ênfase nos conteúdos: valores, ética, conhecimento, política, cosmológica, estética e antropológica e a educação. Um problema evidencia-se na terceira parte: Se a disciplina Filosofia da Educação é oferecida nos primeiros períodos do curso de Pedagogia, junto com as outras disciplinas que compõem a área de fundamentos, como solicitar que os discentes procedam à realização de quatro pesquisas-análises de tal complexidade, sem conhecerem a metodologia de pesquisa?

Albuquerque (2002), em Trilhas e temas da disciplina Filosofia da Educação, a partir da PUC-SP, busca compreender como ela foi se constituindo, historicamente, na década de 40 até 80 , a partir de seus programas de ensino, de seus atores e de sua produção teórica, pois

\footnotetext{
[...] foi na década de 40 que a disciplina Filosofia da Educação apareceu nos programas do curso de Pedagogia da Faculdade de Filosofia, Ciểncias e Letras de São Bento e na Faculdade de Filosofia, Ciência e Letras Sedes Sapientiae, instituições que, junto com outras faculdades, formaram a Pontifícia Universidade Católica de São Paulo. (p. 17).
}

A investigação insere-se no campo de estudos, denominados de história das disciplinas acadêmicas, $e$ trabalha com os referenciais da história das disciplinas acadêmicas, 
da tradição da pesquisa, por meio da interseção da História na Sociologia do Currículo, da teoria dos campos de Pierre Bourdieu, que usou como fontes os documentos oficiais relativos à instituição PUC-SP e à disciplina, os programas de ensino, os textos e livros dos intelectuais nela envolvidos.

Para essa autora, a pesquisa apresenta a seguinte delimitação temporal:

a) No período que vai da década de 1940, ao início dos anos 60, a Filosofia da Educação possuía uma orientação centrada tanto nos pressupostos da filosofia tomista (Faculdade São Bento) quanto nos pressupostos mais ligados à teologia (Faculdade Sedes Sapientiae). A partir da segunda metade dos anos 60, essa orientação desgastada mudou de contornos, adentrando em outra fase na década de 70 ;

b) No período compreendido entre as décadas de 70 e 80 , a disciplina teve uma orientação em que predominou, inicialmente, uma abordagem inspirada no personalismo e na fenomenologia e, posteriormente, numa perspectiva que se denominou progressista ou dialética, baseada nos pressupostos do Marxismo;

c) Em meados da década de 80, percebe-se os indícios do esgotamento da abordagem marxista na educação e, neste caso, na Filosofia da Educação. A disciplina chegou até à década de 90, sem uma orientação filosófica dominante, o que, provavelmente, implicou na configuração que teve no final desse período, momento em que surgiu, por parte de alguns intelectuais da área, um despertar para a necessidade de se investir na discussão de sua identidade (p. 29-30).

O trabalho estrutura-se em quatro capítulos. O primeiro, referente à luta da Igreja na construção da universidade católica, trata do contexto histórico em que se criaram as universidades católicas, em especial, a Pontifícia Universidade Católica de São Paulo e, em seu interior, a Faculdade de Filosofia, Ciências e Letras de São Bento e a Faculdade de Filosofia, Ciências e Letras Sedes Sapientiae, onde se ministrava a disciplina Filosofia da Educação.

A Igreja Católica, como reação à perda da hegemonia nos poderes temporal e espiritual, efetiva, no século XIX, um movimento internacional de redimensionamento do catolicismo. A perda da hegemonia católica se dá pela Reforma Protestante, pelos experimentos de Galileu Galilei (Século XVI), pelas teorias de René Descartes (Século XVII), pelo Iluminismo (Século XVIII), pela Revolução Francesa e por acontecimentos marcantes da transição do século XVIII ao XIX, “[...] atrelados aos ideais de liberdade e igualdade, à supremacia das ciências naturais e matemáticas e ao otimismo da ciência e da técnica - são apontados pela Igreja Católica como sendo as origens da crescente laicização das instituições sociais e do Estado [...]" (ALBUQUERQUE, 2002, p. 32).

No Brasil, a proclamação da República, em 1889, ocasionou profundas mudanças nas relações entre Igreja e Estado, as quais se romperam. Com o fim do Padroado, o Estado proclamou-se laico, laicizando os cemitérios, o casamento civil e instituindo o ensino leigo nas escolas oficiais. 
Para Albuquerque (2002):

O maior incômodo ocasionado pela laicização do regime republicano talvez tenha sido a perda das posições ocupadas, até então, pela Igreja, no que se refere, fundamentalmente, à direção intelectual da sociedade, pois, como afirmou Cury (1988), se a República foi aceita, não se pode dizer o mesmo quanto ao clima laicista em que ela foi proclamada. Isso fez crescer entre os católicos a clareza da necessidade de disputar mais enfaticamente a hegemonia perdida. Um ponto a seu favor era as estatísticas que referendavam ser este uma país genericamente de população católica, embora, tenha sido um catolicismo mais de sentimento do que uma prática efetiva (p. 36).

A reação da Igreja na perseguição da hegemonia perdida efetiva-se nas vozes que combatem o laicismo, principalmente de Dom Sebastião Leme, cujo programa de ação objetivava "converter os católicos em força influente nos destinos da nação" (SALÉM apud ALBUQUERQUE, 2002, p. 38). Além disso:

O ponto chave do seu programa era, portanto, a educação, em cuja pauta constava como proposta: a organização da ação católica; a luta pela defesa, na constituição, do ensino religioso nas escolas públicas; a criação de escolas católicas em todos os níveis, especialmente, a Universidade Católica (CASALI apud ALBUQUERQUE, 2002, p. 38).

Assim, da estratégia adotada pela Igreja, no revigoramento dos laços entre os leigos e a hierarquia eclesiástica, destacam-se as figuras de Jackson de Figueiredo, fundador da Revista A Ordem e do Centro Dom Vital; de Alceu Amoroso Lima e de Leonel Franca, e a criação de diversas instituições, como A Associação dos Universitários Católicos (1929), posteriormente convertida na Juventude Universitária Católica (JUC), o Instituto Católico de Estudos Superiores (ICES) (1932), a Liga Eleitoral Católica (LEC) (1933), e a primeira Faculdade de Filosofia do Brasil (1909), agregada à Universidade de Louvain, na Bélgica, e a Faculdade de Filosofia, Ciências e Letras Sedes Sapientiae (1933), ambas, raízes institucionais da Universidade Católica de São Paulo.

No que concerne à Filosofia, era central seu papel no projeto dos católicos. Para Albuquerque (2002):

Deveu-se a eles a criação do primeiro curso de Filosofia no Brasil. Também como unidade disciplinar, a Filosofia impregnou o curso de Pedagogia da PUC-SP, visto, que, no seu currículo, havia História da Filosofia, Filosofia Social e Filosofia da Educação. Esta, no conjunto das disciplinas que compunham o currículo do curso, teve, na década de 40 e 50, e início de 60, um papel superdimensionado. É que ela corroborou com o projeto católico de socializar os alunos dentro de uma determinada leitura do mundo: a cristã. Para isso, teve especial importância a atuação do catedrático dessa disciplina na Faculdade São Bento, o filósofo Leonardo Van Acker e, na Faculdade Sedes Sapientiae, o padre Dom Geraldo de Proença Sigaud [...] (p. 64-65). 
O segundo capítulo, Filosofia da Educação e Igreja Católica, procede à descrição histórica da Igreja Católica, da PUC-SP e da educação brasileira e sua influência na conformação de uma identidade à Filosofia da Educação. Neste, a autora descreve os impasses que a Igreja enfrentou nas suas relações com o Estado Novo e as ameaças que sofreu com o processo de urbanização da sociedade e com a expansão das seitas pentencostais, em especial, as protestantes, do espiritismo kardecista, da umbanda e do risco que representavam o comunismo e o marxismo.

Internamente, a Igreja padecia também das ameaças do decréscimo das vocações religiosas, da perda da hegemonia na educação secundária em virtude do aumento da inflação na economia, o que fez com que muitas famílias da classe média passassem a preferir as escolas públicas gratuitas, com sua relativa estagnação “[...] em parte ocasionada pela dispersão dos bispos, após a morte, em 1942, de D. Sebastião Leme, centralizador da organização eclesiástica, no Brasil, desde os idos de 1916.” (ALBUQUERQUE, 2002, p. 69), que só se resolveria com a criação da Conferência Nacional dos Bispos do Brasil - CNBB, em 1952.

Assim, com a Constituição de 1946, que previa a elaboração de uma Lei de Diretrizes e Bases para a educação nacional, a Igreja articulou-se para participar na elaboração da LDB.

É nesse contexto que a autora discute:

[...] a experiência disciplinar da Filosofia da Educação na PUC-SP, durante o momento em que esteve, prioritariamente, sob a orientação intelectual/doutrinaria dos catedráticos Leonardo Van Acker e Dom Geraldo de Proença Sigaud.

$\mathrm{Na}$ condição de representantes expressivos da Igreja Católica, a atuação desses catedráticos na disciplina, consistiu, fundamentalmente, em cimentar a sua hegemonia na educação com base ora em argumentos filosóficos inspirados na filosofia tomista, ora em argumentos de cunho teológico-doutrinário. (ALBUQUERQUE, 2002, p. 76).

Assim, na PUC-SP, a identidade da disciplina Filosofia da Educação conforma-se segundo diretrizes de seus professores.

Tal é o caso de Leonardo Van Acker, formado em Filosofia pela Universidade de Louvain, responsável por diversas cadeiras nas unidades que constituíam a PUC-SP, no período de 1921 a 1969, e, pela Cadeira de Filosofia da Educação na Faculdade de Filosofia de São Bento, no período de 1948 a 1955, quando deixou a cadeira.

Segundo Albuquerque (2002), para Leonardo Van Acker:

[...] embora necessária essa relação entre filosofia e pedagogia, esta estava subordinada àquela corroborando com a concepção de Van Acker de que "a parte só se entende no todo e de que, sem a compreensão geral do sentido da filosofia, qualquer conhecimento específico carece de sentido" (GRANJO, 1999, p. 337).

Assim, salvaguardando o papel essencial que tinha a teologia, o saber filosófico, por excelência, era o único capaz de, em função de sua vocação de saber total, ditar as 
regras para as demais ciências. Do mesmo modo, seguindo a linha silogística característica do seu raciocínio, cabia à Filosofia da Educação, em relação às demais ciências educacionais, uma função tão ampla quanto a da filosofia, isto é, a de determinar os fins da educação.

A questão dos valores e dos fins da educação constituía outra problemática central nos programas de Filosofia da Educação, de Leonardo Van Acker (p. 96).

Em se tratando de Maria Isabel Pitombo, graduada em Pedagogia e Doutora em Ciências Humanas - Educação - pela Faculdade de Filosofia Ciências e Letras de São Bento, a orientação dada "[...] à disciplina Filosofia da Educação guarda semelhanças com a de seu mestre Leonardo Van Acker, em sua fidelidade aos preceitos de uma filosofia cristã da educação.” (ALBUQUERQUE, 2002, p. 104).

Outro intelectual destacado na disciplina Filosofia da Educação, na Faculdade Sedes Sapientiae, foi Dom Geraldo de Proença Sigaud, que, ao atuar no período de 1943 a 1968, implicou uma perspectiva de subordinação da filosofia pedagógica à teologia educacional.

Para Albuquerque (2002):

Considerando, portanto, a visão de mundo de D. Sigaud abstraída a partir de suas publicações e de seus programas, não é difícil concluir a que se prestava o ensino de Filosofia da Educação por ele professado. No período em que essa disciplina esteve sob sua responsabilidade foi predominante o elemento doutrinário e normativo, em relação aos aspectos propriamente filosóficos que caracterizaram a atuação de Leonardo Van Acker, mesmo sendo este um autêntico defensor do poder católico. A disciplina Filosofia da Educação teve, na Faculdade Sedes Sapientiae, um sentido bem mais próximo de uma teologia educacional a impregnar os alunos dos ideais cristãos, segundo a perspectiva forjada por uma determinada visão do cristianismo. Finalmente, cabe ressaltar que tanto D. Geraldo de Proença Sigaud quanto Leonardo Van Acker acompanharam as transformações da Igreja Católica em curso, sobretudo a partir da década de 50 e, no entanto, mantiveram seus posicionamentos ligados a ala que lutava pela defesa dos seus privilégios. Por conseguinte, a Filosofia da Educação, cuja cadeira lhes pertencia, refletia prioritariamente essa luta por hegemonia ao invés do processo de abertura político-ideológico por que passava a Igreja. (p. 115).

No terceiro capítulo, Filosofia e realidade social, discutem-se as mudanças estruturais na Igreja Católica, na PUC-SP e na educação brasileira, e a influência na disciplina Filosofia da Educação.

Para Albuquerque (2002):

No que se refere à universidade católica, na década de 60, o modelo teórico que inspirou a prática da disciplina Filosofia da Educação, tanto na Faculdade Sedes Sapientiae quanto na São Bento, deu sinais nítidos de exaustão. Especialmente na Faculdade São Bento, teve lugar um crescente processo de questionamento de seus cursos que passaram a ser considerados obsoletos e descontextualizados face ao complexo panorama social, político e econômico que marcou a sociedade brasileira nessa década. Tais modificações, guardam estreitas relações com os acontecimentos internacionais que envolviam o processo de transformação da própria Igreja Católica. (p. 134-135). 
Nesse sentido, inicia-se na Faculdade de São Bento o processo interno de reformas, mediante revisão e atualização de currículos e contratação de novos professores, respeitandose as exigências preconizadas pela lei $\mathrm{n}^{\circ} 5.540 / 68$, que formava o ensino superior do país.

Outro fator para as mudanças implementadas na instituição refere-se aos alunos, cuja expressiva liderança política e cultural extrapolou a universidade. Assim, na década de 70, em decorrência das transformações da Igreja Católica e da própria PUC-SP, sofre também mudanças a disciplina Filosofia da Educação.

Os fatores que influenciaram, sobremaneira, a disciplina foram os professores oriundos da Sedes Sapientiae e da São Bento, os quais se incorporaram à PUC-SP, e "[...] a contratação de professores que, influenciados sobretudo, pelas correntes fenomenológicoexistencialistas, imprimiram a essa disciplina a marca de suas leituras e pesquisas." (ALBUQUERQUE, 2002, p. 139).

Para Albuquerque (2002):

\begin{abstract}
A influência do personalismo é algo que se verifica no conteúdo dos programas de Filosofia da Educação, na primeira metade da década de 1970, como se confere através do objetivo de "levar o aluno a desenvolver a reflexão filosófica, tendo em vista a compreensão de si mesmo, do outro e do mundo."

Foi dentro de uma abordagem denominada fenomelógica-dialética que um outro professor de Filosofia da Educação, Demerval Saviani, escreveu sua tese de doutoramento e, ao mesmo tempo, influenciou a construção do programa da disciplina Filosofia da Educação. (p. 141-143).
\end{abstract}

Ressalta-se que o curso de pós-graduação em Filosofia da Educação, por ser o único existente na área, constituiu o lócus, onde boa parte dos professores se pós-graduou, o que refletiu em suas atividades docentes no curso de Pedagogia da PUC-SP.

No quarto capítulo, A Filosofia na pós-graduação, descreve-se a disciplina no curso de Filosofia da Educação da PUC-SP, haja vista que ela foi "[...] a primeira instituição a implementar um curso de pós-graduação no âmbito do mestrado e doutorado em Filosofia da Educação, com o intuito de formar profissionais para atuarem nesse campo." (ALBUQUERQUE, 2002, p. 15).

Assim, em 1971, institucionaliza-se, na PUC-SP, o programa de pós-graduação em Filosofia da Educação, em âmbito de mestrado e, em 1977, em âmbito de doutorado.

Os professores do programa "[...] eram todos oriundos da área de Filosofia, seja da graduação ou da pós-graduação, da Universidade de Louvain, na Bélgica, com exceção, de Maria Fernanda Beirão.” (ALBUQUERQUE, 2002, p. 170).

Para Albuquerque (2002):

$\mathrm{Na}$ realidade, desse primeiro grupo de professores, que compunha o corpo docente do mestrado em Filosofia da Educação, pode-se destacar três características: 
primeiro, a formação proveniente da área de filosofia, "sem nenhum envolvimento mais direto com a educação" (Saviani, 1987a, p. 10); segundo, o peso imprimido pela universidade belga, onde foi predominante a orientação neotomista na formação da maioria dos membros do grupo e, por fim, a influência da Fenomenologia. (p. 171-172).

No que se refere à disciplina Filosofia da Educação, embora o programa tenha sido hegemonicamente filosófico, no período de 1972 a 1974, e alterado a partir de 1978, mediante as mudanças no corpo docente e a contratação de professores, a

[...] disciplina Filosofia da Educação, ela permaneceu com o status de obrigatória posto que, era considerada "naturalmente a disciplina-chave que dava nome ao programa, tendo, portanto, que assumir uma posição central (Saviani, 1987a, p. 12). Entretanto, segundo este autor, sua vinculação ao universo mais específico da Filosofia tornava-a "uma disciplina não muito nitidamente caracterizada, tanto devido à fluidez de conteúdos, como devido ao fato de que vários professores foram responsáveis por ela.” [...]. (p. 174).

Ao analisar a tese de Albuquerque (2002), evidencia-se que a construção da identidade da disciplina Filosofia da Educação na PUC-SP se faz tributária dos professores que dirigiam a cadeira e que lhe davam a conotação de sua formação, como foi o caso de Leonardo Van Acker, com o tomismo; de D. Geraldo de Proença Sigaud, com a teologia; e de novos professores contratados, que se filiavam às concepções fenomenológico-existencialistas.

Assim, parte-se do pressuposto que a disciplina Filosofia da Educação, nas diversas instituições e, em especial, na PUC-SP, tem sua identidade definida pelas diretrizes assumidas por seus professores.

Também analisou a disciplina o professor Severino (2000b) no texto A Filosofia da Educação no Brasil; esboço de uma trajetória, admitindo que:

Com efeito, o lugar, por assim dizer, natural, da expressão da Filosofia da Educação
é o do discurso elaborado por aqueles pensadores que pretendem estar construindo
uma teoria filosófica explícita sobre a educação, tal como é feito por pessoas ou
grupos que assumem intencionalmente a educação como objeto de estudo e de
reflexão. (p. 270).

Nesses termos, os educadores em geral, por não assumirem a educação como objeto de estudo e de reflexão, não efetivam a Filosofia da Educação. O que fazem é internalizar uma ou mais concepções filosóficas da educação e deduzir diretrizes para a sua prática. Nesse sentido, pode-se pensar que o filósofo da educação é um especialista que busca construir uma teoria filosófica explícita sobre a educação. Defende-se aqui, posição contrária à do autor, pois, ao tomar a educação como atividade prático-poiética, entende-se que todos os que nela atuam devam tomá-la como objeto de interrogação. Além disso, pensar a Filosofia da Educação como o espaço "[...] do discurso elaborado por aqueles pensadores que pretendem 
estar construindo uma teoria filosófica explícita sobre a educação" é reafirmar a divisão do trabalho na educação entre pensadores-experts e professores, que teriam, respectivamente, os papeis de pensar a educação e de executá-la. Isso joga por terra a ideia de que os processos de formação dos futuros educadores pode ser um processo de construção de uma consciência crítica e reflexiva sobre a educação e de que a disciplina Filosofia da Educação possa ser assumida como interrogação do fazer educativo.

Ao analisar a Filosofia da Educação como disciplina curricular, Severino (2000b) assinalou que, no período colonial e imperial - durante o qual a educação era conduzida hegemonicamente pelos jesuítas - as práticas educativas se pautavam no Ratio Studiorum, mas não havia nenhuma tentativa de fundamentá-la nem justificá-la. Também no início da República não se efetivou nenhum questionamento sobre a legitimidade da educação.

Para Severino (2000b):

\begin{abstract}
Já nas últimas décadas, esta atividade de elucidação filosófica da educação vem se fazendo acompanhar de um concomitante investimento na explicitação do próprio estatuto da Filosofia da Educação, qual seja, do próprio sentido de uma reflexão filosófica sobre a educação, assumida e praticada intencionalmente. Desenvolve-se assim uma metarreflexão, que visa, na verdade, legitimar tal exercício reflexivo, delineando sua identidade. Trata-se de abordar a Filosofia da Educação não mais como um simples produto mas sobretudo como um processo, um modo de exercer o conhecimento sobre a educação, buscando-se assim respaldar sua legitimidade. [...] Além disso, coloca-se também a questão de seu ensino, o que levanta o problema de seu estatuto disciplinar, como componente curricular dos cursos de formação de educadores. (p. 282).
\end{abstract}

Como componente curricular na formação de professores, a disciplina de Filosofia da Educação instituiu-se nos Institutos de Educação/Escola de Professores de São Paulo e do Rio de Janeiro, em nível superior, e nas Escolas Normais, pelo o Decreto-Lei 8.530, de 02/01/1946 - Lei Orgânica do Ensino Normal, que prevê, em seu Artigo 8. ${ }^{\circ}$, o currículo do curso normal do $2 .^{\circ}$ Ciclo, no qual constava, no terceiro ano, a disciplina História e Filosofia da Educação.

No ensino superior, a explicitação da disciplina Filosofia da Educação ainda far-se-ia presente no curso de Pedagogia, por meio do Decreto-Lei 1.190/39, que o cria; pelo Parecer 251/62, do CFE, de autoria do conselheiro Valnir Chagas, que estabelece os conteúdos mínimos e a duração para o curso; pelo Parecer 252/69, do CFE, de autoria de Valnir Chagas, em que se extingue o bacharelado, mantendo apenas a licenciatura; e pelo Parecer 632/69, do CFE, de autoria do conselheiro Newton Sucupira, sobre os conteúdos específicos da faculdade de educação.

Em seu texto, A Filosofia da Educação no Brasil: esboço de uma trajetória, Severino relaciona autores que discutem a Filosofia da Educação. Do ponto de vista histórico, apresenta 
Creusa Capalbo, com As raízes históricas da Filosofia da Educação no Brasil, de 1978; Moacir Gadotti, com seu Pensamento Pedagógico Brasileiro, de 1987. Do ponto de vista interpretativo, cita Demerval Saviani, autor de Tendências e correntes da educação brasileira e A Filosofia da educação no Brasil e sua veiculação pela Revista Brasileira de Estudos Pedagógicos, de 1984. Cita, também, três dissertações de mestrado: Filosofia da Educação: uma disciplina entre a dispersão dos conteúdos e a busca da identidade, de Maria Betânia de Albuquerque, em 1997; A Filosofia da Educação na busca da autonomia intelectual dos educadores, de Maria Ely H. Genro, em 1992; e Concepções teóricas e práticas pedagógicas no ensino de Filosofia da Educação, de Silvio Guarde, em 1998.

Discute, ainda, três marcos institucionais: a Filosofia da Educação como disciplina curricular; os cursos de pós-graduação em Filosofia da Educação, com destaque ao Programa de Filosofia da Educação da PUC/São Paulo de 1971, como pólo irradiador para criação da pós-graduação da Universidade Metodista de Piracicaba (UNIMEP), da Universidade de Campinas (UNICAMP) e da Universidade Federal de São Carlos (UFSCar); o Grupo de Trabalho de Filosofia da Educação na Associação Nacional de Pesquisa e Pós-graduação em Educação (ANPED), espaço de apresentação e discussão de trabalhos de teor filosóficoeducacional, que suscitou a criação do Grupo de Estudos e Pesquisas em Filosofia, Sociedade e Educação na Universidade Estadual Paulista Júlio de Mesquita Filho (UNESP) - campus de Marília e o Núcleo/São Paulo do GT-Filosofia da Educação da ANPED; os veículos de expressão da Filosofia da Educação, incluindo periódicos, eventos científicos e lista de Discussão filosed@ufpel.tche.br do GT Filosofia da Educação da ANPED, além da publicação de obras.

$\mathrm{O}$ autor identifica quatro perspectivas filosófico-educacionais que englobam posicionamentos teórico-filosóficos, escolas, tendências, correntes e vertentes de pensamento.

A primeira, denominada A tecnicidade funcional da educação: ciência e técnica, bases da pedagogia, tem a prioridade das referências objetivas da naturalidade da existência na condução da história dos homens e as utiliza para reconstrução da sociedade, pelo "estabelecimento e aplicação de diretrizes do relacionamento social objetivamente conhecidas e positivamente estruturadas em normas jurídicas" (SEVERINO, 2000b, p. 286). Essa perspectiva instaura-se na modernidade, alicerçada em uma epistemologia racionalista, que se opõe à metafísica e dessacraliza o mundo natural e cultural. É o império da Razão, da mentalidade cientificista e de fundamentações epistemológicas positivistas.

Na educação brasileira, encarnam inicialmente tal postura os Pioneiros da Educação e o Projeto da Escola Nova e, posteriormente, outros teóricos e os construtivistas. Pensa-se a 
reconstrução nacional pela educação, concebida cientificamente, isto é, explicada por categorias fornecidas pela Biologia, pela Sociologia e, principalmente, pela Psicologia. Contraditoriamente, essa educação cientificista seria a alavanca para construção da cidadania e da democracia brasileira.

Que concepção de Filosofia da Educação subjaz e que papel desempenharia nessa visão naturalista da educação? Para Severino (2000b), está “[...] implícita uma concepção filosófica da educação que é então identificada com ensino/aprendizagem” (p. 291) e cuja tarefa fundamental "[...] é a justificação epistemológica do empreendimento educativo e a defesa da utilização dos recursos técnico-científicos para a boa condução dos processos pedagógicos" (p. 290), além da "validação da metodologia de investigação e de expressão do conhecimento científico" (p. 293).

Constituem representantes dessa perspectiva: Anísio Teixeira (um dos mais expressivos pioneiros da educação), Tarso Mazzotti (professor de Filosofia da Educação da Universidade Federal do Rio de Janeiro - UFRJ), José Mario Azanha (professor da Faculdade de Educação da Universidade de São Paulo - FEUSP), Carlos Eduardo Guimarães (exprofessor do Departamento de Educação da Universidade Estadual Paulista Júlio de Mesquita Filho - UNESP/Araraquara), Péricles Trevisan (ex-professor do Departamento de Educação da UNESP/Araraquara), Eduardo Campos Chaves (professor da Faculdade de Educação da Universidade Estadual de Campinas - UNICAMP) e Pedro Goergen (professor da Faculdade de Educação da UNICAMP).

A segunda perspectiva, A eticidade formativa: a educação como construção do sujeito, concebe o que é o aprimoramento da interioridade subjetiva do sujeito individual, potencializado pela educação, sua formação e ações éticas como pilar da construção da sociedade democrática.

Essa perspectiva ancora-se na fenomenologia:

$$
\begin{aligned}
& \text { [...] metodologia geral do conhecimento e esforço hermenêutica da existência } \\
& \text { humana [...] que se desdobra em duas frentes: de um lado, de enquanto antropologia } \\
& \text { sensível à presença marcante da ciência na cultura, vem discutindo o processo e o } \\
& \text { alcance das ciências humanas, buscando, consequentemente, interpelá-las no que } \\
& \text { concerne ao esforço de desenvolvimento de um projeto antropológico: de outro lado, } \\
& \text { ao se tornar metodologia filosófica de correntes neo-humanistas existencialistas, } \\
& \text { subsidia a reflexão ético-antropológicas das mesmas. (SEVERINO, 2000b, p. 298). }
\end{aligned}
$$

Nela situam-se os teóricos Antônio Muniz Rezende (professor de Filosofia da Educação da Faculdade de Educação da UNICAMP), Newton Aquiles Von Zuben (professor de Antropologia e de Filosofia da Educação da Faculdade de Educação da UNICAMP), Creuza Capalbo (professora de Filosofia da Educação da UFRJ e da Universidade Gama 
Filho), Joel Martins (ex-professor da PUC/São Paulo), Dulce Maria Critelli (professora da PUC/São Paulo), Maria Aparecida Bicuda (professora da UNESP), Hilton Japiassu (professor de Filosofia da UFRJ), Sônia Maria Aparecida Ignácio Silva (professora da UNESP/Araraquara), Odone José Quadros (professor da Pontifícia Universidade Católica do Rio Grande do Sul - PUC/RS), Jayme Paviani (professor da PUC/RS), Edvino Aloísio Rabuske (professor da PUC/RS e da Faculdade de Filosofia de Viamão), Paulo Freire, Moacir Gadotti (professor da Faculdade de Educação da USP), Alino Lorenzon (professor da Universidade do Estado do Rio de Janeiro - UERJ), Baldoino Andreolla (professor da Universidade Federal do Rio Grande do Sul - UFRGS), Urbano Zilles (professor da PUC/RS), Tiago Adão Lara (professor da Universidade Federal de Juiz de Fora - UFJF) e Roque Spencer Maciel de Barros (ex-professor de Filosofia da Educação da Faculdade de Educação da USP).

A terceira perspectiva, A educação como lugar de produção e cultivo da sensibilidade desejante: priorizando a esteticidade no pedagógico é "[...] uma incisiva crítica desconstrutiva aos modelos e paradigmas de conhecimento, tanto do campo científico como do campo filosófico, questionando a própria validade e pertinência epistemológica do saber fundado na razão" (SEVERINO, 2000b, p. 307).

Apoiando-se nos pós-modernos ou pós-estruturalistas, Michel Foucault, Derrida, Barthes, Lyotard, Braudrillard, Deleuze e Guatarri privilegiam-se a subjetividade do corpo, elegendo, como objeto de interesse, o imaginário, o inconsciente, o emocional e o corporal, em detrimento da subjetividade do cogito. Severino designa de filosofia arquegenealógica esta vertente, que se propõe a contestar o saber e o poder em seu caráter opressivo, sufocador da liberdade e da criatividade e que tem na reflexão crítica dos pensadores da Escola de Frankfurt a hegemonia da racionalidade, que prevalece, na modernidade, o seu ponto de partida.

Enquadram-se, nessa perspectiva, Rubem Alves (ex-professor da UNICAMP), Tomaz Tadeu da Silva (professor do Departamento de Ensino e Currículo da Faculdade de Educação da UFRGS), Alfredo Veiga-Neto (professor do Departamento de Ensino e Currículo da Faculdade de Educação da UFRGS), Paulo Ghiraldelli (professor da UNESP/Marília), Silvio Gallo (professor da UNIMEP e da UNICAMP), Marisa Faermann Eizirick (professora da UFRGS), Regis de Morais (professor da Faculdade de Educação da UNICAMP), Bruno Pucci (professor da UNIMEP), Antônio Álvaro Zuim, Newton-Ramos de Oliveira (UNIMEP) e Nadja Hermannn Prestes (professora da Faculdade de Educação da UFRGS) e Marilu Fontoura de Medeiros (PUC/RS). 
A quarta perspectiva, A educação como práxis construtora da história: a dimensão da politicidade da prática pedagógica, inspira-se na dialética marxista, apoiando-se no pensamento de Marx, Althusser, Gramsci, Gooldmann, Lukaccs, Adam Schaff, Henri Lefebvre e Agnes Heller.

Para Severino (2000b), mantém-se:

[...] de um lado, a exigência de um olhar de totalidade, herdado da metafísica, e apoiando-se nas aproximações histórico-antropológicas da ciência, a atual reflexão filosófica sobre o homem, faz dele uma imagem de um ser de relações, ser social e histórico, que se constitui através de uma prática real e concreta. Por sua vez, a Filosofia da Educação vê a educação como um processo inserido no processo mais abrangente da existência humana dos educandos. (p. 315).

Os teóricos brasileiros desta perspectiva praxista são Dumerval Trigueiro Mendes (professor da Fundação Getúlio Vargas), Demerval Saviani (professor da Faculdade de Educação da UNICAMP), Carlos Roberto Jamil Cury (professor da Universidade Federal de Minas Gerais - UFMG), José Carlos Libâneo (professor da Universidade Católica de Goiânia), Betty Antunes de Oliveira (professora da Universidade Federal de São Carlos UFSCar), Newton Duarte (professor da UNESP/Marília e Araraquara), Terezinha Rios (professora da PUC/São Paulo), Jefferson Ildefonso da Silva (professor da Universidade Federal de Uberlândia - UFU) e Antônio Joaquim Severino (Professor da Faculdade de Educação da USP).

E quem é Antonio Joaquim Severino? Por que a análise sobre sua contribuição à Filosofia da Educação? Trata-se de um professor de Filosofia da Educação da Universidade de São Paulo/Faculdade de Educação, um dos fundadores do Grupo de Trabalho - GT Filosofia da Educação da ANPED (Associação Nacional de Pós-Graduação e Pesquisa em Educação); seu coordenador, em 1994 e em 1995/1996; bem como autor de livros de Filosofia da Educação e de vários artigos sobre temas de Filosofia da Educação. Ele é, ainda, referência nacional na área de educação e de Filosofia da Educação.

Em A educação, o sujeito e a história: identidade e tarefas da Filosofia da Educação (2000a), tese de livre docência na FE/USP, Severino define como tarefas fundamentais:

\footnotetext{
[...] o exercício de uma reflexão crítica capaz de explicitar e contrapor-se aos significados ideologizados dos discursos pedagógicos, teóricos ou práticos, gerando assim referências elucidadoras da significação mais profunda do pensamento, da legislação, das políticas educacionais bem da realidade social da educação, num determinado contexto histórico.

[...] contribuir para a intencionalizacão da prática educacional, a partir de sua própria construção em ato, ou seja, como presença atuante numa determinada sociedade, num determinado tempo histórico. Intencionalizar a prática educacional é dar-lhe condições para se realizar como práxis, ou seja, ação realizada com sentido, ação pensada, refletida, apoiada em significações construídas, explicitadas e assumidas pelos sujeitos envolvidos. É por isso que se pode definir a Filosofia da
} 
Educação como o esforço para o desvendamento/construção do sentido da educação no contexto do sentido da existência humana. (p. 140-142).

Em texto apresentado no GT-17 - Filosofia da Educação da ANPED, em 1994, e publicado na revista Perspectiva da UFSC, em 1993, em sua tese de livre docência, e em Educação, sujeito e história (2001), o autor afirma que a Filosofia da Educação tem três tarefas: epistemológica, axiológica e ontológica.

Ao analisar a expansão da mentalidade científica e suas fundamentações epistemológicas positivistas no Brasil, ele questiona “[...] se essas ciências, ao explicitar as leis que regem o fenômeno educacional, viabilizando as técnicas bastantes para a condução eficaz da prática educacional, não esgotariam a possibilidade de conhecimento da educação" (SEVERINO, 2000a, p. 144). Essa perspectiva cientificista, no Brasil, inicia-se com o movimento escolanovista, que tem em Anísio Teixeira um dos seus representantes. Ela advoga que a educação necessária à reconstrução social é a forjada pelo conhecimento científico que reconstruirá o homem para uma sociedade nacional e democrática. Ressalta-se que Severino é um dos poucos pensadores da educação que rompe com o mito Anísio Teixeira e explicita sua visão cientificista. Na educação, o cientificismo, cujo pressuposto é a naturalização do processo educação, a concepção filosófica da educação identifica-se com o ensino/aprendizagem. Mas o cientificismo apresenta-se também travestido em teorias diversas, como behaviorismo skineriano, construtivismo, filosofia analítica, e, em todas elas, a dimensão política da educação é denegada.

Em sua tarefa epistemológica, Severino (2001) alega que:

A Filosofia da Educação investe no esclarecimento das relações entre a produção do
conhecimento e o processo da educação. Deve enfrentar um amplo espectro de
questões: a natureza da subjetividade; o ato de ensino ou de aprendizagem; a
efetividade da ciência da educação. Em pauta, a criação de um sistema de saber em
educação, para que se disponha de um corpo de conhecimentos fundados numa
episteme rigorosa e consistente. (p. 128).

Admitida como reflexão axiológica, a Filosofia da Educação, historicamente, explicitou-se desvinculada de referências sócio-históricas. Na tradição filosófica, uma essência humana ideal, abstrata e universal, constituía a referência para definição dos valores, fins e normas do agir humano, com vistas na realização da perfeição da essência dos indivíduos. Na tradição científica moderna, ocorre uma naturalização, ou seja, o homem é considerado um prolongamento da natureza física, um organismo vivo, cuja perfeição é o desenvolvimento pleno de sua natureza biológica, e a ciência e a técnica constituem os novos valores a regularem o agir humano. 
Pondera o autor que, se a Filosofia da Educação tiver uma tarefa axiológica, esta não se identificará com uma sabedoria ética, nem com uma vivência estética. Ao admitir que os valores são produzidos e sustentados pela sociedade, o que torna compreensível o axiologismo sociológico, ele distingue moral e ética, referindo-se à primeira aos valores do tecido social e, à segunda, aos valores universais. Mas a questão central se coloca na crítica à posição da orientação filosófica arquegenealógica, em sua estetização radical das atividades subjetivas, reduzindo a Filosofia da Educação à “[...] uma axiologia, fundada na sensibilidade desejante envolvida no processo educacional.” (SEVERINO, 2000a, p. 159).

Ainda para o autor, “A Filosofia da Educação só poderá indicar valores na condução da prática educacional caso se lastreie numa antropologia fundada em mediações históricosociais" (SEVERINO, 2001, p. 131). Pensa-se que a Filosofia da Educação pode interrogar-se sobre os valores - éticos, políticos, estéticos, principalmente, se quem interroga é aquele que está no exercício da prática educativa.

A terceira tarefa da Filosofia da Educação é Ontológica, mas não metafísica. Ontologia assumida como Antropologia, como "[...] busca do sentido da existência humana como historicidade social." (SEVERINO, 1996, p. 68).

Para Vaz (1991)

A Antropologia Filosófica se propõe encontrar o centro conceptual que unifique as múltiplas linhas de explicação do fenômeno humano e no qual se inscrevam as categorias fundamentais que venham a constituir o discurso filosófico sobre o ser do homem ou constituam a Antropologia como ontologia. (p. 12).

Assim, a tarefa ontológica da Filosofia da Educação é tarefa antropológica.

Severino (2001) classifica essa perspectiva de "praxista", que:

Mantendo a exigência de um olhar de totalidade, herdado da metafísica, e apoiandose nas aproximações histórico-antropológicas da ciência, a atual reflexão filosófica entende o homem como um ser de relações, social e histórico, que se constitui através de uma prática real. (p. 136-137).

As tarefas da Filosofia da Educação seriam, portanto, a construção de uma imagem do homem e a busca do sentido da vida: o "[...] desvendamento do sentido da educação no contexto do sentido da existência humana." (SEVERINO, 1996, p. 70).

$\mathrm{Na}$ cultura ocidental, a educação é compreendida, historicamente, como formação humana,

[...] modo de ser, mediante um devir, modo de ser que se caracterizaria por uma qualidade existencial marcada por um máximo possível de emancipação, pela condição de sujeito autônomo" (SEVERINO, 2006, p. 621) 
Mas, no ensaio: A busca do sentido da formação humana: tarefa da Filosofia da Educação, o autor defende a tese da educação como formação cultural - síntese a seu ver superadora das propostas de formação ética e de formação política. Para o autor, a noção de formação humana em que prevalecia a ética marcou a cultura ocidental - Antiguidade grega e Medievalidade. No período, A educação é vista como garantindo a humanização do homem na medida em que
ela possa contribuir diretamente para a construça do próprio sujeito. A imagem é
dada pela metáfora da identidade e da autonomia do sujeito individual, pessoal que,
princípio de atividade, atua pela força energética de sua vontade livre. A
transformação do mundo, a construção da sociedade, o aprimoramento da existência
objetiva, decorrem diretamente da transformação, do aprimoramento íntimo do
sujeito. A polis, como cidade justa e democrática, será resultante das ações,
eticamente respaldadas, postas pelos indivíduos transformados. (SEVERINO,
2006a, p. 625).

É esta paidéia clássica que predomina na tradição da Filosofia da Educação: aquela em que "[...] a dimensão política é inteiramente derivada da qualidade ética dos sujeitos pessoais.” (p. 624). É possível reconhecer nesta observação a influência do famoso estudo de Werner Jaeger, na obra Paidéia. A formação do homem grego (1994). A análise do autor não é, porém, neutra: ela insiste na continuidade entre o passado arcaico e a democracia grega, tanto quanto busca defender a dominância, na cultura helênica, de um ideal moral bem próximo das teses platônicas e de um individualismo que muitos negam no período clássico. Assim, para Jaeger (1994), “O pensamento ético de Platão e Aristóteles baseia-se, em muitos pontos, na ética aristocrática da Grécia arcaica” (p. 33), na qual “[...] a idéia filosófica de "bem", [...], esse modelo de validade universal, procede diretamente da idéia de modelo da ética da arete $^{*}$ própria da antiga nobreza" (p. 60).

Ressalte-se, todavia, que mesmo Jaeger não pode negar que "[...] a pólis é o marco social da história da formação grega" (JAEGER, 1994, p. 107) e que o homem tematizado nas obras dos grandes gregos é o habitante da pólis - um homem político.

Já na época moderna, pro ação do iluminismo, com a formação dos estados e com a instituição do capitalismo, “[...] a educação passa a assumir, [...], o caráter de uma ação e de uma prestação pública, definindo-se como mediação própria para a constituição da cidadania. E seu grande instrumento é o conhecimento racional.” (SEVERINO, 2006a, p. 629).

Segundo Cambi (1999):

\footnotetext{
*Diz a tradução portuguesa da Paidéia (1994): "Não temos na língua portuguesa um equivalente exato para este termo; mas a palavra "virtude", na sua acepção não atenuada pelo uso puramente moral, e como expressão do mais alto ideal cavaleiresco unido a uma conduta cortês e distinta e ao heroísmo guerreiro, talvez pudesse exprimir o sentido da palavra grega" (p. 25).
} 
Do ponto de vista ideológico-cultural, a Modernidade opera uma dupla transformação: primeiro, de laicização, emancipando a mentalidade - sobretudo das classes altas da sociedade - da visão religiosa do mundo e da vida humana e ligando o homem à história e à direção do seu processo (a liberdade, o progresso); segundo, de racionalização, produzindo uma revolução profunda nos saberes que se legitimam e se organizam através de um livre uso da razão, a qual segue apenas seus vínculos internos (sejam eles lógicos ou científicos, isto é, analíticos ou experimentais), opondo-se a toda forma de preconceito. Será o iluminismo que caracterizará de modo orgânico e explícito este novo modelo de mentalidade e de cultura, com sua fé no sapere aude e na raison como critique; com sua oposição à metafísica e seu vínculo estreitíssimo com a ciência e o seu iter lógico e experimental. (p. 197-198).

Todavia, se há emancipação da religião; se o homem se torna um ser histórico; e se a liberdade e o progresso se tornam vetores de sua existência, contraditoriamente, a racionalização se institui como paradigma que determina toda a vida social e molda os indivíduos em todas as esferas de sua vida. Assim, esse período se marca, pelo menos até 1950, segundo Castoriadis (1992), pelo enfrentamento entre duas significações imaginárias sociais: autonomia e expansão ilimitada do domínio "racional".

A educação, compreendida como mediação para a cidadania e a razão como crítica, traveste-se a primeira na modelagem de comportamento dos indivíduos produtivos, integrados, conformes e, a segunda, em computação mecânica, uniformizante, em sistema universal e pretensamente exaustivo.

Nessa época, a Filosofia "[...] passa a ser "serva da ciência", exercendo-se fundamentalmente como reflexão metacientífica" (SEVERINO, 2006a, p. 629). Mas, contraditoriamente, institui-se a Filosofia da Educação.

Porém, na contemporaneidade, segundo Severino, não mais vigiriam nem a ética nem a política como referências básicas da educação: é o tempo da filosofia pós-moderna ou pósestruturalista, que, nos pensamentos de Foucault, Deleuze, Guatarri, Lyotard, Beaudrillard, Mafesoli etc, expressa a crítica da razão como agente de repressão. Para Severino (2006), essa tendência é " [...] diretamente tributária da crítica desenvolvida pelos teóricos da Escola de Frankfurt" (p. 629). Todavia, ele aponta que a posição dos pós-modernos e dos frankfurtianos, em relação à razão, não é idêntica. Ao citar Goergen (2001), ele explicita que, para os primeiros, a razão iluminista perdeu sua legitimidade e, para os segundos, a razão necessita ser salva das armadilhas de instrumentação e, consequentemente, de seu uso contra o próprio ser humano.

Para Severino (2006a), a contribuição dos frankfurtianos, principalmente de Adorno e Horkheimer, enseja uma nova concepção de educação - educação como formação cultural:

A idéia de formação cultural dá à educação uma finalidade intrínseca de cunho mais antropológico do que ético ou político, num sentido estrito. Até para transformar os indivíduos em pessoas éticas e políticas, a educação precisa efetivar-se como 
formação cultural. No entanto, em si mesma, a educação não tem como garantir, diretamente, que as pessoas se tornem éticas - ela é uma experiência eminentemente pessoal -, nem como metanoia assegurar o aprimoramento do social - a revolução política é uma experiência exclusiva do sujeito coletivo em sua especificidade. (p. 633).

Em 1994, na primeira reunião do Grupo de Trabalho de Filosofia da Educação da ANPED, Severino (1993a) apresentou o trabalho intitulado Proposta de um universo temático para a investigação em Filosofia da Educação: as implicações da historicidade, que, inerente à existência humana, "[...] marca com radicalidade todas suas manifestações particulares, entre as quais o conhecimento e a educação, o que impõe exigências específicas para a abordagem filosófico-educacional" (p. 11). O texto compõe-se de três partes, nas quais se discutem a historicidade humana: a educação como prática histórica; as perspectivas de abordagem: exigências para com a pesquisa em filosofia da educação e delineamento de alguns campos temáticos.

Em a historicidade humana, admite-se a existência humana como prática históricosocial, isto é, como prática produtiva, política e simbólica, na qual o “[...] homem é aquilo que ele se faz, ao fazer as coisas" (SEVERINO, 1993a, p. 13). Ao tomar a educação como uma prática mediada e mediadora da existência humana, esse autor a entende como " [...] o investimento do grupo social com vistas à inserção dos indivíduos humanos no tríplice universo da prática produtiva, da prática social e da prática simbolizadora, ou seja, nos universos do trabalho, da sociabilidade e da cultura" (p. 14). Ressalta-se ainda, na categoria da historicidade, o caráter histórico da verdade.

No que se refere à educação, Severino (1993a) ainda alega que:

Intencionalizar a prática educacional é transformá-la em práxis, ou seja, ação
pensada, refletida, apoiada em significações construidas, explicitadas e assumidas
pelos sujeitos que agem.
Assim sendo, se se pode entender a filosofia como esforço de esclarecimento da
existência humana pelo desvendar de seu sentido, deve-se entender a Filosofia da
Educação como esforço para o desvendamento do sentido da educação no contexto
do sentido da existência humana. (p. 16).

No que se refere à pesquisa em Filosofia da Educação, o professor aponta como exigências: a interdisciplinaridade, a tridimensionalidade do enfoque filosófico-educacional antropológico, axiológico e ontológico -, o diálogo rigoroso, atento e crítico com os filósofos do passado, a busca da universalidade a partir da particularidade e a produção de "[...] uma teoria que possa informar a prática" (SEVERINO, 1993a, p. 19). Decorrente da tridimensionalidade do enfoque filosófico-educacional, apontam-se alguns campos temáticos: a Filosofia da Educação e a construção do conhecimento (âmbito epistemológico); a prática 
educacional como tema da Filosofia da Educação (âmbito axiológico), e a educação e a existência histórica dos sujeitos (âmbito axiológico). O primeiro campo - o epistemológico incluiria o estatuto da Filosofia da Educação, a Educação e a construção do conhecimento. $\mathrm{O}$ segundo - o axiológico - compreenderia o sentido da educação como prática, as relações entre: educação e trabalho, educação e prática política, educação e prática cultural, ética e educação e estética e educação. O último e terceiro campo - o ontológico - abordaria a educação e a existência histórica do homem, a educação no processo de humanização e a educação e a liberdade da pessoa humana.

Em Paradigmas filosóficos e conhecimento da educação: limites do atual discurso filosófico no Brasil na abordagem da temática educacional, publicado em 1993b, Severino questiona se o político e o educacional estão implícitos na reflexão filosófica dos autores brasileiros, que tentam desenvolver uma reflexão mais personalizada:

O envolvimento do filósofo com as problemáticas da política e da educação é apenas um acidente contigencial de sua trajetória ou uma exigência marcada pela necessidade do próprio filosofar?" (p. 133).

Para responder à questão, o autor analisa a tradição metafísica clássica na sua condição de resistência; a tradição positivista em sua crescente consolidação, a tradição subjetivista e a tradição dialética, que se fazem presentes na cultura filosófica brasileira.

Na tradição metafísica clássica, “[...] a ética, a política e a filosofia da educação desenvolvidas [...] são fundamentalmente essencialistas, já que os valores que norteiam a ação humana estão inscritos na própria essência do homem” (p. 135). Os pensadores dessa tradição, neotomistas fundamentalmente, são Ubiratan de Macedo, que se dedica à filosofia política e à filosofia do direito; Dom Beda Kruse, que se ocupa da didática e da filosofia da educação sob a influência da fenomenologia de Husserl e de Edith Stein; José Geraldo Vidigal de Carvalho, que se consagra a temas políticos e educacionais; Tarcísio Meireles Padilha, que se dedica à filosofia política etc.

A tradição positivista é abordada em suas correntes neopositivistas e transpositivistas.

Nas primeiras, por força de seus pressupostos-epistemológicos, o único papel da filosofia é apenas de "[...] subsidiar o discurso científico, garantindo-lhe que sua linguagem possa ser uma linguagem formalmente rigorosa" (SEVERINO, 1993b, p. 137). Nestas, a ciência e a técnica são tornadas os novos deuses, sendo a primeira a única via de conhecimento válido e a segunda, o único caminho operacional, tanto para as coisas, como para os homens. Para os neoposivitistas, até mesmo na política e na educação, devem viger a ciência e a técnica, o que justifica a ausência da problemática político-educacional em suas 
elaborações teóricas. Seus objetos de interesse situam-se nas vertentes dos fundamentos lógico-formais do conhecimento científico e da matemática; da construção de uma linguagem precisa e rigorosa; e do processo do conhecimento científico e sua expressão rigorosa e formal.

Para Severino (1993b):

[...] de sua concepção do conhecimento em geral e do conhecimento científico em particular como formas de aprendizagem, os filósofos brasileiros transpositivistas, embora fundamentalmente preocupados com a epistemologia, vêem na aprendizagem uma comprovação concreta de suas posições epistemológicas básicas. Assim, enquanto as referências à psicogênese do conhecimento fazem brotar preocupações com a aprendizagem e com a educação, as referências à sociogênese abrem espaço para abordagens da dimensão política. (p. 138-139).

Mas, também para o autor, “[...] esta concepção do processo educacional [...] não consegue ainda dar conta da problemática político-educacional. A educação é prática social que vai além dos processos de aprendizagem, envolvendo necessariamente vetores políticos." (p. 139).

A tradição subjetivista investe nos fundamentos antropológicos e éticos dos processos educacionais, pois a educação é o investimento do próprio sujeito para tornar-se cada vez mais como tal. Essa tradição engloba a fenomenologia, os neo-humanismos e a arquegenealogia.

$\mathrm{Na}$ fenomenologia, a questão político-educacional é assumida:

[...] de um lado, enquanto epistemologia sensível à presença marcante da ciência na cultura contemporânea, vem discutindo o processo e o alcance das ciências humanas, buscando, consequentemente, interpelá-las no que concerne ao esforço de desenvolvimento de um projeto antropológico; de outro lado, ao se tornar metodologia filosófica das correntes neo-humanistas existencialistas, subsidia a reflexão ética-antropológica das mesmas. (SEVERINO, 1993b, p. 142).

A fenomenologia, ao privilegiar a epistemologia e a antropologia, prioriza o sujeito pessoal, e denega a dimensão política.

Os neo-humanismos em quase todas as suas vertentes, para o professor:

[...] desenvolvem uma reflexão ético-política, uma vez que sua compreensão da existência humana envolve também uma teoria da ação, colocando então a questão da historicidade e da intersubjetividade. Enquanto a dimensão política do agir se vincula mais à perspectiva de historicidade, a dimensão educacional se entrelaça com a perspectiva da intersubjetividade, a educação sendo vista também como forma específica de comunicação. (SEVERINO, 1993b, p. 144).

Os arquegenealogistas, ao interpelarem a política e a educação, o fazem de forma crítica e contestatória, denunciando o "[...] caráter sistêmico, desumanizador e repressivo dos aparelhos envolvidos" e contestando "[...] a cumplicidade saber/poder" (SEVERINO, 1993b, p. 145-146). Embora a questão educacional não seja prioridade para eles, à exceção de 
Rubens Alves, que, em seu texto $O$ preparo do educador, afirma ao utilizar metáforas, que concebe a educação contrapondo educador versus professor, vocação versus profissão e denuncia o gerenciamento racional/científico da atividade educativa.

Na tradição culturalista, a questão política é abordada na perspectiva jurídica, qual seja, “[...] enquanto norma decorrente de uma exigência ontoaxiológica dos sujeitos humanos, se manifestando historicamente como fenômeno cultura" (SEVERINO, 1993b, p. 148). A questão educacional, à exceção do trabalho de Roque Spencer Maciel de Barros, é apenas incidental. Ao citar Reale, Severino (1993b) apresenta a concepção de educação dos culturalistas:

[...] como a formação do homem em função do modelo ideal de pessoa, do seu dever-ser (REALE, 1979, p. 190). Ao educador, enquanto sujeito pessoal, sensível a esse modelo, cabe levar o educando ao mesmo, tendo bem presente que o homem é composto de três valencias: ethos (querer), pathos (sentir) e logos (pensar). Às mediações educacionais cabe criar as condições indispensáveis e propícias para que, sob o estímulo e a orientação do mestre, cada aluno possa realizar por si o seu projeto existencial, em uníssono com os valores comunitários. (REALE, 1979, p. 206) (p. 148-149).

Na tradição dialética, evidenciam-se dois momentos: referentes à filosofia hegeliana e à filosofia marxista, cujas categorias centrais são, respectivamente, o espírito absoluto e a práxis responsáveis pela criação. Mas é na dialética marxista que predomina, sobremaneira, a filosofia política. A questão educacional não possui, aí, relevância, exceto nas obras de Gramsci e Althusser. Os marxistas brasileiros também não têm tratado, com prioridade, a questão educacional, pelo contrário, refletem sobre questões gerais da cultura. Ainda nessa tradição, a Teoria Crítica da Escola de Frankfurt também não explicita a questão educacional. Mas, alguns autores brasileiros, entre eles, Paulo Sérgio Rouanet, já tematizam, influenciados pelos frankfurtianos, a questão educacional.

Concluí-se, ser expressiva a contribuição do professor Severino (1996) à Filosofia da Educação, com o artigo A Filosofia da Educação: buscando o sentido histórico e social da educação. Neste, ele afirma que ela "[...] se propõe fundamentalmente como uma antropologia, ou seja, busca do sentido da existência humana como historicidade social" (p. 68) e ocupa

[...] um lugar de síntese, já que lhe cabe situar a educação em relação à existência humana, [...] precisa operar levando em conta as contribuições de todas as ciências que investem igualmente no esclarecimento dos diversos aspectos, necessariamente múltiplos, da prática histórico social da educação. (p. 71).

Embora não explicitada pelo professor Severino, em seu texto A Filosofia da Educação no Brasil: esboço de uma trajetória, outra perspectiva se nos apresenta. É a 
desenvolvida por Lílian do Valle, professora da Universidade do Estado do Rio de Janeiro, a partir da obra de Cornelius Castoriadis:

[...] filósofo da indeterminidade: do novo. O que é que se destina? Nas teias do labirinto humano, ao incessante desvelamento das condições de emancipação humana que tem, em seu vocabulário, um nome: autonomia. Declinado como atividade teórica, este "poder fazer" é filosofia; atividade política, este "dever deliberar" é democracia.

Castoriadis acreditava que a psicanálise e a educação, tanto quanto a política, sendo terrenos onde se obra pela emancipação humana, são, no entanto, tarefas impossíveis. Impossíveis por dever, a fim de fazer surgir a autonomia, apoiar-se numa autonomia que, paradoxalmente, ainda não existe (VALLE apud CASTORIADIS, 1999, p. 9-10).

Para pensar a formação humana, Valle busca em Aristóteles, em sua obra Ética a Nicômaco, a exigência "de que o objeto visado pela reflexão possa efetivamente concernir à prática e ao uso humano". Objeto da reflexão e sua justificativa, a prática humana e, em especial, a prática social da educação, deve ser continuamente buscada, para que se possa construir-lhe o sentido.

Ao compreender Castoriadis e sua atividade filosófica como a concretização de um compromisso de interrogação ilimitada sobre o que se é e se vive no espaço social-histórico, para fundamentar ação consciente e deliberada do humano, ela reafirma sua coerência com a definição que ele apresenta de filosofia: “[...] compromisso com a totalidade do pensável” (p. 17), que se expressa na "[...] atitude de levar a sério a convicção que fez nascer a filosofia: a de que tudo o que vivemos e concebemos pode e deve ser objeto de nossa interrogação." (VALLE, 2008, p. 495-496).

Assim, verifica-se, em Castoriadis, a filosofia como interrogação aberta e incessante, como criadora dos sentidos que erigem o mundo próprio do sujeito e o mundo coletivo do social-histórico; “[...] como possibilidade de exame crítico da atividade de instituição das crenças, valores, aspirações, hábitos que definem o modo de ser coletivo e o modo de ser particular de cada um" (VALLE, 2008, p. 496); como atividade consciente e deliberada, que só pode se concretizar no espaço democrático, motivo pelo qual filosofia e democracia são intimamente ligadas; como "[...] exercício de contínua busca e aquisição de uma disposição que se trata, a partir daí, de tentar tornar durável” (VALLE, 2008, p. 497); disposição adquirida para a interrogação.

E o que é necessário para que ela se concretize?

Antes tudo, a atitude de que as certezas, os hábitos, as crenças e os valores, que constituem o mundo próprio, podem e devem ser continuamente colocados em questão. 
O que levaria a construir tal disposição para a interrogação se é muito mais cômodo, menos angustiante, submeter-se ao mundo instituído?

Castoriadis (1999) afirma que se filosofa para "[...] salvar nosso pensamento e nossa coerência" (p. 15). Assim, a frase de Sócrates - "o anexetastos bios ou biotos, vida sem exame, a vida sem reflexão, não é vivível, eu prefiro morrer" (p. 54), é reescrita por Castoriadis e por Valle: faz-se filosofia, porque é pelo exame que se constrói, de forma coerente, o sentido cotidiano da prática. Isto significa que tal atividade pode e deve ser realizada por cada um que o desejar e buscar romper com a submissão e conformismo ao que recebeu da psique, da história e das instituições do social-histórico.

Podem-se, assim, apontar as contribuições de Castoriadis à educação, no que diz respeito à teoria: crítica à filosofia como uma função reservada aos experts e, consequentemente, a divisão teoria e prática, o caráter alienante da teoria, que se transforma em dogma, impedindo a interrogação.

Sua maior contribuição é, contudo, a sua reflexão ontológica, que serve de base todo o resto :

Dizemos: há uma reflexão/elucidação que se preocupa com o ser/ente e se pergunta sobre o que lhe pertence de próprio e o que lhe pertence na medida em que ele é para nós - isso é, pelo fato de refletirmos sobre ele. Esta formulação afirma que é impossível separar reflexão sobre o ser e reflexão sobre os entes, como é impossível separar reflexão sobre o ser e "teoria do conhecimento" [...] (CASTORIADIS, 1999, p. 16).

Em sua reflexão sobre o que cada ser tem de próprio, Castoriadis explicita o diferencial de sua produção teórica - o poder de criação. Presente nos viventes em geral, esse poder de criar sentido é determinado pela funcionalidade. Presente no humano, esse poder de criação dá existência às significações sociais que constituem o magma, sustentáculo da existência individual e coletiva.

Mas, o que é o humano? O que dele se pode dizer? Qual o seu modo de ser?

Para Valle (2008), ele se nos apresenta como "complexo" e "enigmático". Para compreendê-lo e elucidá-lo mister se faz tomar-se da dimensão lógico-ontológica e da dimensão imaginária.

Na dimensão lógico-ontológica:

.O fato de que uma vida social tenha podido existir mostra que esta lógica identitária ou conjuntista tem apoio no que existe - não somente no mundo natural no qual a sociedade surge, mas na própria sociedade, que não pode representar e se representar, dizer e se dizer, fazer e se fazer sem colocar em ação também esta lógica identitária ou conjuntista, que só pode instituir e se instituir instituindo também o legein e o teukhein. [...] Porque a lógica identitária é lógica da determinação, se especifica segundo os casos como relação de causa e efeito, de meio a fim ou de implicação lógica. (CASTORIADIS, 1982, p. 210). 
Ao utilizar essa dimensão e os princípios que ela comporta - identidade, nãocontradição, terceiro excluído, equivalência entre propriedade e classe - são possíveis o representar, o dizer e o fazer humanos e explicá-los. Tal dimensão é intrínseca ao humano, mas está longe de exauri-lo. Outra dimensão, especificamente humana, rompe com a determinidade: é a dimensão imaginária, criadora, que só existe porque o humano, para além de pura composição biológica, é psique.

As duas dimensões - lógica conjuntista-identitária e imaginária - permitem o conhecimento e a compreensão do humano. A primeira, no âmbito da determinidade, a segunda, no âmbito da criação individual e coletiva.

É a dimensão imaginária, criadora, a grande contribuição de Castoriadis à educação. Ele não formalizou uma teoria pronta, acabada, uma vez por todas. Para Valle (2008), ele tomou como objeto de reflexão as

[...] duas extremidades que definem a auto-alteracão: a aprendizagem - que, entendida como categoria biológica, demarca no fenômeno mais amplo da adaptação animal o lugar do humano (1999, p. 40-42) - e a paidéia, o processo de formação desse ser que é, em toda a natureza, o único a quem é dada a possibilidade de autonomia. (p. 510).

Mas, o respeito à Castoriadis, à sua produção teórica e à compreensão da possibilidade de apoiar-se nele, para elucidar a educação, levou Valle a:

Entrar no Labirinto, mais exatamente fazer ser e aparecer um Labirinto ao passo que
se poderia ter ficado "estendido entre as flores, voltado para o céu”. É perder-se em
galerias que só existem porque as cavamos incansavelmente, girar no fundo de um
beco cujo acesso se fechou atrás de nossos passos - até que essa rotação,
inexplicavelmente, abra, na parede, fendas por onde se pode passar
(CASTORIADIS, 1987, p. 10).

Ela presta prestar honras ao Mestre Filósofo, ao tomar sua teoria não como dogma, mas como criação de interrogações que alimentam o pensamento. É o que faz a autora, ao explicitar algumas contribuições do filósofo. Uma delas remete à própria definição do que é Filosofia e sua finalidade: “[...] compromisso com a totalidade do pensável” (CASTORIADIS, 1999, p. 17), “[...] para salvar nosso pensamento e nossa coerência” (idem, p. 15). A encarnação dessa definição torna objeto de interrogação tudo o que se vive e se concebe, para a construção refletida, consciente e deliberada de sentidos do mundo coletivo e individual. Tal concepção traz implícito que a filosofia é uma disposição que não é pura, nem espontânea, mas que deve ser criada pelo nomos e pela paidéia e preservada continuamente. Portanto, embora não encarnada por todos, nem todos filosofam e interrogam-se, ela existe como possibilidade. Ela não é também, disposição/atribuição específica dos experts, 
produtores de teoria, que refletem sobre os outros e sua prática e não sobre si próprio. Ainda que:

\begin{abstract}
Não existe teoria como "visão" do que é nem como constituição ou construção sistemática e exaustiva do pensável, de uma vez por todas, ou gradual e progressivamente desenvolvida. [...]

Há um fazer teórico, que só emerge em um dado momento da história. Uma atividade, uma empresa humana, um projeto social-histórico: o projeto de teoria. Dar conta e razão - logon didonai - de tudo: do mundo, dos objetos que nos cercam, das suas "leis", de nós mesmos, desta própria atividade. E dizer isso é ainda estar na teoria - nesse projeto e prosseguir nele. Perguntar-se: o que quer dizer dar conta e razão - é ainda querer dar conta e razão [...]. (CASTORIADIS, 1987, p. 19).
\end{abstract}

Assim, a teoria, que pode ter caráter alienante, em atitude cientificista ou dogmática, o que impede a interrogação, é um empreendimento humano, uma criação, uma necessidade.

Na educação, as interrogações seriam:

Quem é esse ser (sempre encarnado e particular) que tenho diante de mim, e o que
ele me revela sobre o modo de ser (racional, mas também estético e afetivo) desse
que eu chamo correntemente de aluno?; mas também: "O que é, de onde veio para
onde vai essa sociedade que tenho diante de mim, e o que isso me revela sobre o que
posso e desejo chamar de educação, professor, aluno?" (e aí, por exemplo: Até
onde, em nossa experiência formativa contemporânea, a idéia de natureza humana
foi criticada, ou permanece intacta, justificando algumas das ações correntemente
adotadas?) (VALLE, 2008, p. 499).

Tais questionamentos sobre a sociedade e a concepção de educação, de aluno, de professor, enfim, sobre a própria natureza do humano, em que todo professor deveria se colocar, não é o que acontece. Imerso no cotidiano da prática, com dupla ou tripla jornada de trabalho, esse que assume, hoje, a função de professor, em consequência do seu próprio processo formativo, da dicotomia entre teoria e prática, mas também do seu conformismo e submissão, pediu demissão daquilo que é mais caro ao humano - a atividade do pensamento. Como tornar essas interrogações permanentemente abertas e presentes no cotidiano educacional?

Pensa-se que essas interrogações são concernentes ao coletivo da educação, mas não exclusivamente. Elas têm implicações, mas, são também ressonância do social-histórico. Por isso, a realidade da educação pode e deve ser objeto de interrogação de todos, principalmente daqueles que a vivem cotidianamente.

De acordo com essas interrogações, Valle (2008) admite que a filosofia só pode ser entendida "como uma ontologia” (p. 499): “[...] possibilidade de se interrogar sobre a própria existência e sobre seus sentidos" e "[...] interrogar também as teorias de que lançamos mão para pensar os seres em suas diferenças" (p. 500). 
É na reflexão ontológica que a autora sustenta outra contribuição: a impossibilidade de se explicar totalmente a realidade humana e social, utilizando conceitos e teorias das ciências (naturais, físicas, biológicas e matemáticas), não pelo fato de o indivíduo ser um incognoscível absoluto, mas “[...] dos termos primeiros e últimos, há compreensão direta e não conhecimento discursivo" (ARISTÓTELES apud CASTORIADIS, 1987, p. 55). Para compreender o humano, o autor explicita as dimensões da lógica conjuntista-identitária, cujo principio é a determinidade, e a dimensão imaginária, cujo princípio é a criação. Na dimensão da lógica conjuntista-identitária, destacam-se a técnica e a ciência, esta definida:

[...] como produção e reprodução dos fenômenos na experimentação e observação, como inferência formalizável (...) dos enunciados, como correspondência unívoca de uns e outros; constitui os seus resultados como verificáveis e acessíveis [...] (p. $41)$.

Marcada pela verificabilidade/comunicabilidade e pela temporalidade cumulativa, a ciência moderna tornou-se espaço de aplicação da divisão do trabalho, de acumulação de resultados e conhecimentos efetivos. Mas, e a dimensão imaginária? Para além do projeto de instaurar uma ciência da sociedade e dos homens, a dimensão imaginária, instauradora de sentidos, não se permite formalizar, pois não é possível eliminar do conhecimento a " $[\ldots]$ subjetividade de uma experiência intransferível e singular", e nem tentar explicar o homem, tomando apenas um de seus aspectos - a especialização da ciência. Assim, “[...] no que se refere à existência humana, não há "ciência" que permita explicar ou formalizar essa criação ininterrupta de sentidos, não há ciência do sentido [...]” (VALLE, 2008, p. 505), embora existam teorias, que lhe sejam próprias e que permitem elucidá-la.

Castoriadis (1987) ainda denuncia que o magma de significações imaginárias sociais da sociedade capitalista transformou o "[...] pensamento em Razão - ou seja, finalmente, em "teoria" submetida ao identitário-conjuntista [...]" (p. 134-135), ocultando a historicidade e a socialidade do pensamento e do indivíduo, ocultando a práxis e a poiésis, ocultando a criação do imaginário radical, do imaginário social, além da própria "lógica" e da Razão.

Para o Filósofo da imaginação social e psicanalista:

Pensar: elucidar; não "teorizar". A teoria é somente um momento da elucidação,
sempre lacunar e fragmentaria. (...) Mas lógica e teorização, sem serem simples
"instrumentos", só adquirem sentido quando mergulhadas numa atividade de
elucidação que as ultrapassa e não poderiam ficar simplesmente submetidas a seus
critérios. Mas também: fazer (o que, convém lembrar, não quer dizer "passar ao
ato") - e fazer com um outro (p. 136).

A frase "Pensar: elucidar; não teorizar" dá o que pensar. Muitas vezes, os termos elucidar, pensar, teorizar e cogitar são confundidos. No Novo Dicionário Eletrônico Aurélio - 
versão 5.0 (2004) - elucidar: esclarecer, explicar; pensar: refletir, raciocinar; cogitar: pensar, refletir e teorizar: ação de contemplar, examinar. Para o autor,

O mundo histórico é o mundo do fazer humano. Esse fazer está sempre em relação com o saber, mas esta relação precisa ser elucidada" (90), o que consiste no "[...] trabalho pelo qual os homens tentam pensar o que fazem e saber o que pensam. (CASTORIADIS, 1982, p. 14).

E é a elucidação, o pensamento, que deve ser concretizado, quando se toma como "objeto" a atividade da educação:

Educar uma criança (quer como pai ou como pedagogo) pode ser feito com uma consciência e uma lucidez mais ou menos grandes, mas é por definição impossível que isso possa ser feito a partir de uma elucidação total do ser da criança e da relação pedagógica (CASTORIADIS, 1982, p. 92).

Para o filósofo, o essencial da educação é a própria relação que se estabelecerá entre a criança e o educador, e a evolução desta relação, dependerá do que um e outro farão. Considerando que o mesmo ocorre na psicanálise, também atividade prático-poiética " $[\ldots]$ definida por um objetivo de transformação e não por um objetivo de saber" (1987a, p. 50), pode-se pensar como o autor, que a teoria que se lhe é específica, também corresponde à educação, bem como ao próprio humano:

\begin{abstract}
Assim como não procede do desejo de saber do analista, a atividade analítica não consiste na aplicação desse saber. Não é somente que o conhecimento da teoria não basta para ser analista; é que a maneira com que ela intervém no processo analítico não tem alhures modelo nem equivalente e nenhuma fórmula simples permite definir a sua função. Pode-se abordá-la dizendo que o analista tem principalmente necessidade do seu saber para não lançar mão dele, ou melhor, para saber o que não deve ser feito para atribuir-lhe o papel do demônio de Sócrates: a injunção negativa. Como nas equações diferenciais, nenhum método geral permite, nesse caso, achar a solução, que é preciso descobrir cada vez (sem nem mesmo haver garantia de que a solução existe). A teoria orienta, define classes infinitas de possíveis e de impossíveis, mas não pode predizer nem produzir a solução (CASTORIADIS, $1987^{\mathrm{a}}$, p. 51).
\end{abstract}

Segundo Valle (2000), a educação é, para Castoriadis, uma atividade prático-poiética, cujo objetivo é a formação humana, a autotransformacão, que pode se realizar na psicanálise, na educação e na política. Em Encruzilhadas do labirinto III: o mundo fragmentado (1992), no texto Psicanálise e Política, o autor, ao falar da psicanálise, explicita o que é a atividade prático-poiética:

[...] os dois participantes são agentes. O paciente é o principal agente do desenvolvimento da sua própria atividade. Eu a chamo de poiética, pois ela é criadora; seu êxito é (deve ser) a auto-alteracão do analisando, isto é, falando com todo rigor, o aparecimento de um outro ser. E eu a chamo de prática, pois chamo de práxis a atividade lúcida, cujo objeto é a autonomia humana, e pela qual o único "meio" de atingir esse fim é essa própria autonomia (p. 156). 
Da citação, poder-se-ia entender que a psicanálise é atividade prática-criadora. Retornando a divisão aristotélica, as atividades humanas classificam-se em práxis e poiésis. As primeiras têm o fim em si mesmas e implicam a realização dos fins da existência. São a política e a theoria. As segundas são atividades de produção de meios para fins que lhe são exteriores. Diferente de Aristóteles, Castoriadis (1999) concebe a práxis como “

[...] uma modalidade do fazer humano. [...] É a atividade que considera o outro como podendo ser autônomo, e tenta ajudá-lo a chegar à sua autonomia. [...] ela é o próprio, não dos seres humanos em geral, mas da subjetividade reflexiva e deliberante (p. 62).

Portanto, as atividades que visam a certa transformação do humano - psicanálise, educação e política - são práxis. Para o próprio autor (1992), “[...] a subjetividade, como instância reflexiva e deliberante (como pensamento e vontade) é projeto social-histórico cuja origem [...] é datável e localizável” (p. 121). Mas ela é uma virtualidade, uma possibilidade e pode ser um projeto. Como atividade consciente, realiza-se numa lucidez "relativa", pois o seu objeto é o novo e o "[...] seu próprio sujeito é transformado constantemente a partir desta experiência em que está engajado e que ele $f a z$, mas que o faz também” (1982, p. 96). Para Valle (2008), “[...] a impossibilidade de discernir estas duas dimensões é, pois, o que caracteriza as atividades voltadas para a criação da prática, mas também das condições e modos de autonomia humana" (p. 511 - nota 5) e define as atividades prático-poiéticas.

Eis por que a educação é prático-poiética, para Castoriadis:

[...] a educação é poiésis, porque visa a uma finalidade que lhe é exterior, porque deve constituir-se em atividade criadora de algo que não estava lá, inicialmente, e que é precisamente a liberdade - a autonomia humana, Porém, como essa finalidade não está determinada a priori, como ela é um poder poder ser, a poiésis educativa jamais poderia ser assimilada a uma téchne. Assim, a educação é práxis, porque, atividade lúcida, deliberada e deliberante, seu objeto, sua finalidade, é o próprio exercício dessa lucidez e dessa deliberação. Na educação, portanto, o fim corresponde à própria atividade que o produz: a autocriacão. (VALLE, 2002, p. 271).

Assim, a filosofia da educação é compromisso de interrogação incessante para a construção da autonomia.

Outras contribuições de Castoriadis para a educação estão na crítica às concepções que a entendem como atualização de potencialidades preexistentes no indivíduo, como "resultados objetiváveis" e como aprendizagem, categoria biológica.

Ressalte-se que, na obra do filósofo, a reflexão sobre a paidéia é fundamental e,

[...] sempre tematizada em sua íntima relação com a política e a psicanálise - o que, sem dúvida, permite elucidar o caráter político da educação, tanto quanto sua responsabilidade na criação de subjetividades reflexivas e deliberantes (VALLE, 2008, p. 510), 
ainda, que ela não se concretize em obra explícita. 


\section{A DISCIPLINA FILOSOFIA DA EDUCAÇÃO NA UNIVERSIDADE FEDERAL DE VIÇOSA}

Neste capítulo, tratar-se-á do material empírico, as disciplinas de Filosofia da Educação do curso de Pedagogia da Universidade Federal de Viçosa, entendido como uma construção social, uma Instituição. Como toda criação é criação dos homens e a eles se dirige, serão privilegiadas as representações e os pensamentos dos professores que ministraram tais disciplinas e os dirigentes acadêmicos que as aprovaram.

\subsection{O curso de Pedagogia na Universidade Federal de Viçosa}

O curso de Pedagogia da Universidade Federal de Viçosa, que, em geral, guarda identificação/semelhança com seus congêneres em outras instituições, foi tomado como o caso empírico para análise do objeto de estudo: as disciplinas de Filosofia da Educação.

O curso de Pedagogia da Universidade Federal de Viçosa data da década de 70, quando o então Reitor Professor Edson P. Magalhães levantou a idéia de criação de um curso de Letras e convidou o Professor Guy Capdeville para estudar o assunto.

Historicamente, o curso teve sua origem vinculada tanto às demandas de formação de recursos humanos para a microrregião de Viçosa, motivado pela Lei de Diretrizes e Bases da Educação Nacional - Lei 4.024 - quanto à expansão interna da Universidade Federal de Viçosa. Em 1970, submeteu-se à Reitoria da UFV a proposta de criação do curso de Pedagogia, em substituição à ideia inicial de implantação de um curso de Letras, uma vez que as disciplinas de cunho pedagógico já eram oferecidas pelo Departamento de Metodologia, ligado às Ciências Domésticas, e isto representaria menores custos na composição do quadro docente. Analisadas a proposta e a justificativa, em 25 de junho de 1971, foi autorizado, pelo Conselho de Ensino, Pesquisa e Extensão da instituição o funcionamento do curso de Pedagogia pelo Ato n. ${ }^{\circ}$ 17/71. Seu reconhecimento pelo MEC efetivou-se pela Portaria n. ${ }^{\circ}$ 142, de 11 de fevereiro de 1981, e pelo Decreto n. ${ }^{\circ}$ 81.260, de 27 de janeiro de 1978. A organização e a implantação do curso tiveram à sua frente os Professores Padre Antônio Mendes e Guy Capdeville. Ele nasceu vinculado ao Departamento de Metodologia da Escola Superior de Ciências Domésticas - ESCD, criada em 1952. Esta remonta a 1948, na Universidade Rural do Estado de Minas Gerais - UREMG, hoje Universidade Federal de Viçosa, à criação do serviço de extensão rural.

Segundo Marques (1993): 
A implantação da ESCD e dos cursos tornou-se possível a partir do acordo feito com a Universidade de Purdue, dos Estados Unidos.

Especialistas renomados serviram em Viçosa, MG, até 1965, ajudando a construir a Escola que seria modelo a ser seguido por outras instituições. Contudo, a idéia de ter um programa de extensão rural ligado à universidade não foi adotada nem mesmo pela UREMG. Dessa maneira, a ESCD, que havia sido criada para o ensino e para a pesquisa dos problemas práticos das famílias do meio rural, tais como os relacionados com alimentação e nutrição, higiene e saúde, habitação, vestuário, cuidados dos membros da família e administração do lar, acabou sendo afastada do público a que fora direcionada inicialmente.

Ao contrário do que se deu na Europa e nos Estados Unidos, no Brasil a Economia Doméstica, nas universidades, não surgiu como uma necessidade concreta sentida pela sociedade e identificada por cientistas locais. Em nosso caso, a Economia Doméstica foi trazida no bojo de um programa de extensão rural ligado às ciências agrárias, segundo o modelo americano dos Land Grant Colleges. (p. 46-47).

A ideia original da criação da Escola Superior de Ciências Domésticas era marcada por ações de extensão universitária, a ser realizada em conjunto com o Serviço de Extensão, e incluía pelo lado das economistas domésticas, a atuação junto às famílias rurais em orientações de higiene, puericultura, técnicas de armazenamento e conservação de alimentos, objetivando a melhoria das condições de vida da população rural.

Como declarou Marques (1993), a ideia original de extensão universitária, que marca a Escola Superior de Economia Doméstica, não se concretizou e ela se transformou em curso superior, afastada do público a que fora direcionada inicialmente.

Ressalta-se ainda que, na Universidade Federal de Viçosa, a Escola Superior de Economia Doméstica, com o seu curso, e o curso de Economia Rural não foram alocados na área de Humanas, mas sim como parte integrante dos cursos das Ciências Agrárias da UREMG - Universidade Rural do Estado de Minas Gerais, hoje UFV.

A expansão da área de humanas, na Universidade Federal de Viçosa, é tributária da Reforma Universitária, definida pela Lei n. ${ }^{\circ}$ 5.540/68, que estabelece uma nova configuração às universidades. Dentre as diversas mudanças, ressaltam-se a extinção das cátedras vitalícias, a instituição do regime de departamentos, a adoção da unidade entre ensino e pesquisa, o sistema de créditos, a matrícula por disciplina e a dedicação exclusiva dos docentes. Além dessas modificações, a lei definiu a universalidade de campo, que obrigava a qualquer instituição oferecer pelos menos quatro cursos nas áreas fundamentais das Ciências Agrárias, Naturais, Humanas e Letras, bem como oferecer dois cursos de caráter técnico-profissional.

Assim, a federalização da UFV e a institucionalização da Lei n. ${ }^{\circ} 5.540$ são fatores determinantes na criação/expansão da área de humanas na UFV, com os cursos de Economia Doméstica, Pedagogia (1971), Letras (1975), Administração (1975) e Economia (1976). 
É nesse contexto que o curso de Pedagogia da UFV é criado em 1971. Em 1972, este Departamento passa a denominar-se Departamento de Pedagogia e, em 1973, Departamento de Educação, que, desde 1978, vincula-se ao Centro de Ciências Humanas, Letras e Artes CCH. Tal fato é decorrente da federalização da UREMG em 1978, quando as escolas existentes se departamentalizaram e a ESCD transformou-se em Departamento de Economia Doméstica - DED, dando origem a dois departamentos e dois cursos, respectivamente, Pedagogia e Nutrição. O primeiro vestibular para o curso de Pedagogia foi realizado em 1972 e, em 1975, colou grau a primeira turma.

A criação do curso de Pedagogia da UFV se dá na conjuntura da necessidade de adequar o sistema educacional ao modelo de desenvolvimento econômico, implementado a partir de 64. Essa fase de expansão gerou, a partir de 1968, uma série de medidas práticas destinadas a tratar o problema da educação de forma estratégica, evitando encará-la, unicamente, do ponto de vista de suas manifestações mais imediatas, tais como a solução dos problemas gerados pela aceleração do ritmo de crescimento da demanda social pela educação. A reforma do sistema educacional passava a ser uma exigência não apenas com o objetivo de resolver problemas mais prementes da área, mas, principalmente, de adequar o sistema educacional ao modelo de desenvolvimento econômico.

A Reforma Universitária, empreendida pela ditadura militar e modelo que ainda vigora implantada pela Lei 5.540/68, instituiu algumas alterações, sendo, talvez, a mais fundamental, a mais importante, o desmanche do modelo da década de 30, que previa a participação da área de educação no âmbito da Faculdade de Filosofia, Ciências e Letras, na forma como estava organizada: bacharelados acrescidos da formação pedagógica $(3+1)$ e o Curso de Pedagogia. Com a extinção da Faculdade de Filosofia, Ciências e Letras, a Faculdade de Educação passa a ter a responsabilidade pela formação pedagógica e pelo curso de Pedagogia. O Artigo 30, da lei, estabelecia que a formação de professores para o ensino de 2. grau e a preparação de especialistas para o trabalho de planejamento, supervisão, administração, inspeção e orientação far-se-iam em nível superior.

O campo da Pedagogia, como parte do campo educacional, responsável pelo conhecimento produzido, envolvendo o ensino e a escola, não ficou imune a essas medidas. Os efeitos das novas ideias fizeram-se sentir com a aprovação em 1969, pelo Conselho Federal de Educação, do Parecer 252/69, de autoria do Professor Valnir Chagas, que regulamentou, 30 anos após sua primeira organização, ocorrida em 1939, o currículo mínimo para o curso de Pedagogia, assim como as habilitações Orientação Educacional, Administração, Supervisão, Inspeção Escolar e Magistério das Disciplinas Pedagógicas do 2. 
grau. O curso transformara-se em curso profissionalizante. Assim, o curso de Pedagogia da Universidade Federal de Viçosa já nasce profissionalizante, oferecendo ensino normal e administração escolar.

Em 1974, o Departamento de Educação, responsável pelo Curso de Pedagogia, introduz uma modificação radical, ao institucionalizar a Licenciatura Curta, com a obrigatoriedade de o discente cursar 114 créditos, e a Licenciatura Plena, com 155 créditos. Passa, então, a oferecer as habilitações: Administração Escolar de $1^{\circ}$ Grau (licenciatura curta) e Administração Escolar de $1 .^{\circ}$ e $2 .^{\circ}$ Graus (licenciatura plena), Supervisão Escolar de 1. ${ }^{\circ}$ Grau (licenciatura curta) e Supervisão Escolar de $1 .^{\circ}$ e $2 .^{\circ}$ Graus (licenciatura plena) e Magistério (licenciatura plena). Constituía esta modalidade uma habilitação aligeirada de administradores e supervisores escolares. Era o império da lógica do mercado. A criação das profissões dos especialistas em educação constituía novo nicho na área de educação. A oferta da licenciatura curta em administração e supervisão escolar perdura, por 20 anos, até a vigência do Catálogo de Graduação de 1994/95.

Entranhado entre as montanhas de Minas, o Departamento de Educação da Universidade Federal de Viçosa permanecia em isolamento, físico e intelectual, distanciado das discussões nacionais sobre a reformulação do Curso de Pedagogia. Não havia vinculação e participação institucional do chefe do Departamento de Educação e, ou, do Coordenador do Curso de Pedagogia na ANFOPE - Associação Nacional pela Formação do Profissional da Educação, que se instituíra como referência nacional:

\begin{abstract}
Um marco histórico sobre o curso de Pedagogia - a sua especificidade e identidade, a polêmica sobre especialistas versus generalista, professor versus especialistas, é o Encontro Nacional, após vários encontros regionais, organizado pelo MEC em novembro de 1983, em Belo Horizonte, com a intenção de dar continuidade ao processo de reestruturação curricular, iniciado em 1978. Neste Encontro os educadores tomam para si a condução do processo de discussão e formam a Comissão Nacional de Reformulação dos Cursos de Formação de Educadores CONARCFE - que passa a reunir-se com regularidade e a constituir-se em fonte importante de conhecimento sobre a formação do educador. Em 90, a CONARCFE transforma-se em ANFOPE - Associação Nacional pela Formação do Profissional da Educação, que a cada dois anos, em seus Encontros Nacionais, tem estabelecido princípios para a estruturação/reestruturação dos cursos de formação dos profissionais da educação e se responsabilizado pela discussão da formação de professores - Pedagogia e Licenciaturas outras. (Documento da Comissão de Especialistas de Pedagogia - Portaria MEC 641/97).
\end{abstract}

Em 1999, sob a orientação da Coordenação do Curso de Pedagogia e da Chefia do Departamento de Educação, procedeu-se a uma reformulação do Curso de Pedagogia. Embora não tivessem sido promulgadas, as Diretrizes Curriculares para o Curso - Proposta da Comissão de Especialistas - vinham constituindo parâmetro para a reformulação do curso em 
diversas universidades, mas não foram consideradas. Levando-se em conta que grande parte do coletivo do colegiado do Departamento de Educação não acompanhava as discussões nacionais e nem as legislações educacionais, os responsáveis pela reforma conseguiram convencer a quase totalidade do Colegiado do Departamento de Educação a aprová-la. Contudo, o novo e primeiro projeto político-pedagógico do curso de Pedagogia da UFV muito pouco diferia das situações anteriores, em que apenas se estruturava a grade curricular do curso. Trazia explícitas as competências e habilidades a serem desenvolvidas no futuro pedagogo, tópicos de estudo - conteúdos básicos (contexto histórico e sociocultural, contexto da educação básica e contexto do exercício profissional), aprofundamento ou diversificação da formação e estudos independentes. O projeto incluía, ainda, monografia de final de curso e prática pedagógica.

E em que consistia a prática pedagógica? Para os autores do projeto políticopedagógico da Pedagogia na UFV:

A relação teoria-prática é entendida como eixo articulador da produção do
conhecimento na dinâmica do currículo. Assim, esta articulação está presente desde
os primeiros anos do curso sob a forma de Estudos Pedagógicos Integrados (EPI),
como instrumento de integração e conhecimento do aluno com a realidade social,
econômica e do trabalho pedagógico. O EPI possibilita a interlocução com os
referenciais teóricos dos quatro primeiros períodos do curso por meio de atividades
práticas orientadas pelos professores do período correspondente, que atuarão de
forma a construir um projeto pedagógico do semestre. (UFV, Projeto Político
Pedagógico, 1999, p. 22).

Este era um dos diferenciais do projeto, que não logrou êxito e se transformou numa disciplina "sem pai, nem mãe" e sem identidade e conteúdo. Os problemas eram da ordem de concepção: da relação teoria-prática, de interdisciplinaridade e de projeto pedagógico.

Se o projeto político-pedagógico visava, como perfil do pedagogo, habilitar

[...] a atuar no ensino, na organização e gestão de sistemas, unidades e projetos educacionais; produção e difusão do conhecimento, tendo a docência como base obrigatória de sua formação e identidade profissionais. (UFV, Projeto Político Pedagógico, 1999),

no Catálogo de Graduação da UFV (2000), esta era a definição de sua área de atuação:

O licenciado em Pedagogia é habilitado a atuar na docência: educação infantil, séries iniciais do ensino fundamenta, e disciplinas de formação pedagógica do nível médio; organização de sistemas, unidades, projetos e experiências escolares e não-escolares; produção e difusão do conhecimento científico e tecnológico do campo educacional; e nas áreas emergentes do campo educacional. (p. 253).

O projeto previa uma carga horária de 3.210 horas, assim distribuídas: disciplinas obrigatórias - 2.205 horas; disciplinas optativas - 240 horas; estágios - 480 horas; e estudos independentes - 300 horas. Ressalta-se que, no cômputo das horas de disciplinas de 
fundamentos da educação, estão inclusas as disciplinas História da Educação (150 horas), Psicologia da Educação (180 horas), Sociologia da Educação (120 horas), Economia e Educação (45 horas) e Filosofia e Educação (165 horas) totalizando 615 horas, o que representava 26,99\% da carga horária das disciplinas obrigatórias e optativas. Observe-se, ainda, que há uma hierarquização na carga horária: Psicologia da Educação, Filosofia da Educação, História da Educação, Sociologia da Educação e Economia e Educação.

Em cumprimento aos trâmites administrativos, o projeto pedagógico foi aprovado no Colegiado do Departamento de Educação, no dia 10 de novembro de 1999, conforme Ata da XXI da reunião ordinária. Foi apreciado pela Comissão Coordenadora do Curso de Pedagogia, no dia 17 de novembro de 1999; aprovado pela Câmara de Ensino do Centro de Ciências Humanas, Letras e Artes, conforme Ata n. 01 de 29 de novembro de 1999; e aprovado pelo Conselho de Graduação, no dia 08 de dezembro de 1999, conforme Ata de n. ${ }^{\circ}$ 301. Ressalta-se que nesta reunião, antes da apresentação, discussão e votação do projeto pedagógico do curso de Pedagogia, contraditoriamente, foi relatado pela conselheiracoordenadora, o "[...] projeto do curso de Economia Domestica, onde houve a criação da Licenciatura Plena em Educação Infantil [...] Proposta esta que, colocada em votação, foi aprovada por unanimidade" (Conselho de Graduação, 1999, p. 9 - Ata 301 de 08/12/1999). No que diz respeito à Pedagogia, a conselheira-coordenadora do curso fez o relato do projeto, no qual

[...] extinguiram-se as antigas habilitações existentes e criou-se a Licenciatura em Pedagogia, incluindo a educação infantil [...] O conselheiro [...] propôs a aprovação da proposta apresentada, que, colocada em votação, foi aprovada por unanimidade. (Conselho de Graduação, 1999, p. 9 - Ata 301 de 08/12/1999).

É interessante chamar a atenção para o fato de que, nessa reunião, as habilitações até então existentes no curso de Pedagogia, ou seja, licenciatura plena em Administração Escolar de $1 .^{\circ}$ e $2 .^{\circ}$ graus, Supervisão Escolar de $1 .^{\circ}$ e $2 .^{\circ}$ graus e Magistério das Matérias Pedagógicas, são extintas. Cria-se o curso de Pedagogia em uma universidade onde ele já existia, só que com a inclusão da educação infantil, que é mencionada apenas quando se define a área de atuação do pedagogo. O processo n. ${ }^{\circ}$ 011770, de 10 de dezembro de 1999, referente ao Projeto Pedagógico do Curso de Pedagogia, não faz menção à Pedagogia como Educação Infantil, e esta aparece na grade curricular do curso de Pedagogia como uma disciplina de 60 horas-aula teórica e 30 horas-aula prática e como parte do nome de uma disciplina - Prática de Ensino Fundamental e Educação Infantil, embora na ementa desta, nada se refira à educação infantil. 
Essa situação é contraditória, já que, na mesma instituição, uma universidade pública federal, e na mesma reunião do Conselho de Graduação, cria-se um curso de Educação Infantil vinculado a um Departamento e a um curso - o de Economia Doméstica, e cria-se um curso de Pedagogia, que inclui a Educação Infantil, cujo projeto não existe. Salienta-se ainda que, perante o Ministério da Educação, a UFV já possuía um curso de Pedagogia, com três habilitações, reconhecido pelo Parecer nº 3.159/77 - Portaria nº 142 de 11/02/1981.

Em 2002, os discentes do curso de Pedagogia foram informados, pelo Registro Escolar da UFV, que o curso de Pedagogia os licenciava, mas não os habilitava para nada. Assim:

\begin{abstract}
Estarrecidos e indignados ficamos, nós estudantes, enquanto possíveis formandos de setembro de 2002 e marco de 2003, pois na época, da reformulação do Curso, nos foi garantido, pela Coordenadora do Curso, pelo Chefe do Departamento de Educação, respaldados no Colegiado do Departamento que aprovou a nova grade curricular do Curso de Pedagogia por unanimidade, que ao optarmos pela nova grade teríamos o diploma de licenciado em Pedagogia, com cinco habilitações: Coordenação Pedagógica, Gestão Escolar, Magistério das Matérias Pedagógicas, Educação Infantil e Docência nas séries iniciais do Ensino Fundamental.

E mais, esclarecemos que, naquela época, não nos foi possibilitada a permanência na grade a que pertencíamos, uma vez que alguns membros da Comissão de Reformulação de Curso afirmaram que se insistíssemos em permanecer nesta grade, não teríamos previsão para a formatura, pois o Departamento de Educação não possuía corpo docente suficiente para ministrar as disciplinas das duas grades, sendo ainda muitas disciplinas extintas o que inviabilizaria a conclusão do curso. (UFV, 2002, 09 - processo n. $\left.{ }^{\circ} .6 .097 / 02\right)$.
\end{abstract}

Após a divulgação desse imbróglio na imprensa, o Departamento de Educação se deu conta do problema e elaborou uma proposta de solução - " [...] adequação curricular no sentido de minimizar os prejuízos advindos da reforma curricular instituida em 2000, para os alunos que ingressaram até 1999 [...]" (UFV, 2002, p. 1), consubstanciada no processo 6097/02, de 28 de junho de 2002, encaminhando-a a Câmara de Ensino do Centro de Ciências Humanas, Letras e Artes, que a aprovou. Submetida ao Conselho de Graduação, em sua $337^{\text {a }}$ reunião, no dia 09 de julho de 2002, a proposta de retorno dos discentes ao Catálogo de Graduação de origem foi indeferida. Mas o Conselho de Graduação:

\footnotetext{
APROVOU a incorporação, no Catálogo de Graduação de 2000 e posteriores, as habilitações Supervisão Escolar de $1 .^{\circ}$ e 2. ${ }^{\circ}$ Graus, Magistério das Matérias Pedagógicas do 2. ${ }^{\circ}$ Grau e Administração Escolar de 1. ${ }^{\circ}$ e 2. ${ }^{\circ}$ Graus, constantes dos Catálogos de Graduação 1998 e 1999, devidamente reconhecidas pelo MEC, conforme Parecer n. 3.159/77; Portaria n. 142, de 11.02.81; Decreto n. 81.260, de 27.01.78 (CONSELHO DE GRADUACAO, 2002, p. 70 - processo n. ${ }^{\circ} .006097$ ).
}

Tal postura do Conselho de Graduação denota desconhecimento das legislações educacionais, despotismo em relação à Comissão Coordenadora do Curso de Pedagogia e ao Colegiado do Departamento de Educação, irresponsabilidade institucional e descompromisso 
para com a formação de professores e para com os seus discentes, lesados por terem de cursar mais um semestre, quando “optaram” pelo Catálogo de 2000, formação aquém da preconizada pelas grades curriculares específicas de cada habilitação, sendo obrigados a optarem pela nova grade curricular e assumirem uma denúncia pública para que o problema fosse enfrentado.

Como pensar que os três currículos específicos: de Administração Escolar de $1 .^{\circ}$ e $2 .^{\circ}$ Graus, de Supervisão Escolar de 1. ${ }^{\circ}$ e 2. ${ }^{\circ}$ Graus e de Magistério das Matérias Pedagógicas do 2. Grau, com, respectivamente, 2.415 horas-aula, 2.595 horas-aula e 2.580 horas-aula, pudessem ser equiparados a um currículo de 3.210 horas-aula, sem lesar a formação dos discentes?

Para tentar solucionar o impasse entre as Coordenações de Curso da Pedagogia e da Economia Doméstica, na disputa pela Educação Infantil e a impossibilidade de apostilamento e emissão de diploma de 33 alunos da habilitação em Educação Infantil, no curso de Economia Doméstica, o Conselho de Ensino, Pesquisa e Extensão (CEPE) da UFV, em reunião do dia 24 do mês de outubro de 2003, deliberou:

Criação de Licenciatura em Educação Infantil (00-07459, 02-11474 e 03-02826).
Após ampla discussão, e com base no relatório da Comissão instituída pelo Ato n.
002/2003/CEPE, de 11/09/2003, foram aprovadas as seguintes propostas: 1)
extinção da Educação Infantil como habilitação na Licenciatura em Economia
Doméstica; 2) extinção da Licenciatura em Economia Doméstica; 3) criação da
Licenciatura em Educação Infantil, para início em 2005; 4) extinção da habilitação
em Educação Infantil no curso de Pedagogia; 5) permissão aos egressos dos cursos
de Pedagogia e de Licenciatura em Economia Doméstica, que concluíram o curso
seguindo o catálogo 2000, 2001, 2002 ou 2003, de matrícula na Licenciatura em
Educação Infantil, para complementação da formação e obtenção de novo título; 6)
permissão aos alunos que estão cursando a Licenciatura em Economia Doméstica,
que seguem o catálogo 2000, 2001, 2002 ou 2003, para migrarem para o curso de
Educação Infantil; e 7) permissão aos aprovados no vestibular de 2004, para
Economia Doméstica, para migrarem para o curso de Licenciatura em Educação
Infantil em 2005. (CEPE, 2003, p. 4 - Ata 394/2003).

Dessa forma, a habilitação em Educação Infantil na Economia Doméstica foi oferecida, na UFV, como licenciatura do curso de Economia Doméstica nos Catálogos de Graduação de 2000, 2001, 2002 e 2003. Ressalte-se que, no Catálogo de Graduação de 2000, não se explicita a regulamentação do curso de Educação Infantil; no de 2002, ela é explicitada pela Lei n. ${ }^{\circ}$ 7.387, de 21.10.85, que prevê a profissão de economista doméstico, e o Decreto n. 92.524 , de 07.04.86, que a regulamenta e, no Catálogo de 2003, ela não consta, mas sim autorização da Lei Estadual n. ${ }^{\circ}$ 272, de 13/11/1948 (Bacharelado), e Ata da Câmara Curricular da Escola Superior de Ciências Domésticas, de n. ${ }^{\circ}$ 4, de 28/12/1971 (Licenciatura). Nenhuma delas é pertinente para regulamentar e, ou, autorizar a Licenciatura Plena em Educação Infantil na Economia Doméstica. Em 2005, passa a viger o curso de Educação 
Infantil com autorização do CEPE - Ata n. ${ }^{\circ}$ 394, de 30/10/2003 e projeto pedagógico elaborado por professores da economia doméstica, responsáveis pelo curso.

No que concerne ao curso de Pedagogia e em que pese a ciência dos prejuízos advindos da reforma curricular implantada em 2000, o currículo (disciplinas e carga horária) permaneceu o mesmo até 2007, só que habilitando em Administração Escolar de $1 .^{\circ}$ e 2. ${ }^{\circ}$ Graus, Supervisão Escolar de $1 .^{\circ}$ e $2 .^{\circ}$ Graus e Magistério das Matérias Pedagógicas do Ensino Médio, conforme deliberação do Conselho de Graduação.

Em 2008, o curso é reestruturado por força das Diretrizes Curriculares. O novo projeto político-pedagógico do curso de Pedagogia da UFV - 2008 foi elaborado com base nas seguintes legislações: Resolução $\mathrm{CNE} / \mathrm{CP}$ n. ${ }^{\circ}$ 1, de 15 de maio de 2006, que institui as diretrizes curriculares nacionais para o curso de graduação em Pedagogia, licenciatura; Parecer CNE/CP n. ${ }^{\circ}$ 05/2005, de 13 de dezembro de 2005, que trata das diretrizes curriculares nacionais para o curso de Pedagogia; e Parecer CNE/CP n. ${ }^{\circ}$ 3, de 21 de fevereiro de 2006, que reexamina o Parecer CNE/CP n. ${ }^{\circ}$ 5/2005.

Mas o que constitui as diretrizes curriculares? De acordo com o Parecer CNE/CP n. ${ }^{\circ}$ 5/2006, elas são:

\begin{abstract}
[...] orientações normativas destinadas a apresentar princípios e procedimentos a serem observados na organização institucional e curricular. Visam a estabelecer bases comuns para que os sistemas e as instituições de ensino possam planejar e avaliar a formação acadêmica e profissional oferecida, assim como acompanhar a trajetória de seus egressos, em padrão de qualidade reconhecido no País (p. 5-6).
\end{abstract}

As diretrizes curriculares nacionais foram instituídas pelo Conselho Nacional de Educação, em contraposição aos Currículos Mínimos fixados pelo Conselho Federal de Educação. De acordo com o Parecer CNE/CES 67/2003, pode-se afirmar que o objetivo das Diretrizes curriculares nacionais é "[...] garantir a flexibilidade, a criatividade e a responsabilidade das instituições de ensino superior ao elaborarem suas propostas curriculares, por curso." (p. 5).

Assim, questiona-se: qual o sentido que a Câmara de Ensino do Centro de Ciências, Letras e Artes, a Coordenação do curso de Pedagogia e o Colegiado do Departamento de Educação atribuíram às DCNs? A identidade do curso de Pedagogia determinada pelas DCNs, foi assumida ou se buscou construí-la segundo o desejo do coletivo envolvido? Qual foi a contribuição da Câmara de Ensino?

Institucionalizado no âmbito do Estado brasileiro, pela Lei n. ${ }^{\circ} 9.394$, de 20 de dezembro de 1996, que estabeleceu as diretrizes e bases da educação nacional, o projetopedagógico tornou-se uma das tarefas dos estabelecimentos de ensino e dos cursos e pode ser 
compreendido como "[...] estratégico para o Estado na consecução da reforma educacional no interior das escolas, ele é também estratégico para aqueles que almejam a sua efetiva democratização.” (ROCHA, 2004, p. 95).

O Projeto Político-Pedagógico do Curso de Pedagogia da UFV - 2008 contém uma breve introdução sobre o curso de Pedagogia na UFV; a apresentação de desafios educacionais atuais apontados pela legislação (Parecer CNE/CP n. ${ }^{\circ}$ 5/2005, Parecer CNE/CP n. ${ }^{\circ}$ 3/2006 e Resolução CNE/CP n. ${ }^{\circ}$ 1/2006); uma exposição sobre educação básica, LDB e DCN dos artigos da LDB $\left(14 .^{\circ}, 22 .^{\circ}, 30 .^{\circ}, 62 .^{\circ}\right)$ e da Resolução CNE/CP n. ${ }^{\circ} 1 / 2006\left(3 .^{\circ}\right.$ e $4 .^{\circ}$ e respectivos parágrafos únicos e incisos); e a proposta pedagógica que compreende os objetivos do curso, o perfil do licenciado e a matriz curricular. Na proposta pedagógica, tomase a Resolução CNE/CP n. ${ }^{\circ}$ 1/2006, em seu Artigo 4. ${ }^{\circ}$, Parágrafo Único e respectivos incisos, identificando-a à identidade do curso, que na UFV opta "[...] pela docência, com ênfase na pesquisa e gestão, [...]" (UFV, 2007, p. 21). No que concerne aos objetivos, aponta os exarados no Artigo 4..$^{\circ}$ da Resolução em seu Parágrafo Único e respectivos incisos, acrescidos dos seguintes objetivos:

1) Compreender e analisar as atividades, além da docência, que envolvam participação na organização e gestão de sistemas e instituições de ensino.

2) Compreender e analisar atividades que envolvam planejamento, execução, coordenação, acompanhamento e avaliação da educação, de projetos e experiências não escolares.

3) Analisar a natureza da profissão, foco de sua formação, mapeando as competências, habilidades e as atitudes necessárias para o trabalho pedagógico.

4) Avaliar e propor soluções para os problemas educacionais por meio de uma aprendizagem significativa.

5) Demonstrar interesse pela pesquisa e investigação do processo educacional.

6) Demonstrar interesse pela extensão como interlocução e troca de conhecimento e experiências com as entidades escolares e não escolares. (p. 21).

Pensa-se que os objetivos propostos pela UFV, além dos previstos no Artigo 4. ${ }^{\circ}$, são, na realidade, competências, atitudes e habilidades do egresso do curso, do licenciado. Estes definem o perfil do licenciado, que, no caso da UFV, foi definido, ipsis literris, pelo Artigo 5. ${ }^{\circ}$, da Resolução CNE/CP n. ${ }^{\circ} 1$, de 15 de maio de 2006.

Na matriz curricular, núcleos norteadores de organização curricular, transcrevem-se os artigos 7..$^{\circ}$ e.$^{\circ}$ da Resolução CNE/CP n. ${ }^{\circ} 1$, de 15/05/2006. O primeiro define a carga horária mínima de 3.200 horas, distribuídas em 2.800 horas de atividades formativas, 300 horas de Estágio Supervisionado e 100 horas de atividades teórico-práticas de aprofundamento, a se concretizarem em iniciação cientifica, extensão e monitoria. O segundo define como será efetivada a integralização em disciplinas, seminários e atividades 
predominantemente teóricas, práticas de docência e gestão educacional, atividades complementares e estágio curricular.

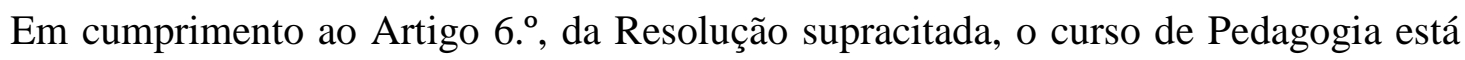
estruturado em três núcleos norteadores: Conteúdos Básicos, Conteúdos Específicos de Aprofundamento e Complementação e Conteúdos Integradores. Para concretizar tal proposta, definiram-se três áreas de conhecimento no Departamento de Educação: Fundamentos da Educação, Gestão da Educação e Didática. A área de Fundamentos da Educação é constituída pelas disciplinas Fundamentos da Educação Infantil, Fundamentos da Educação Especial, Fundamentos da Educação de Jovens e Adultos, História da Educação, Sociologia da Educação, Filosofia da Educação, Psicologia da Educação, Antropologia e Educação e Metodologia de Pesquisa.

Considerando a aplicação dos princípios de flexibilidade, criatividade e responsabilidade institucional na elaboração do projeto pedagógico de cada curso, pensa-se, pelas análises dos programas analíticos, que as disciplinas Fundamentos da Educação Infantil, Fundamentos da Educação Especial e Fundamentos da Educação de Jovens e Adultos poderiam estar na área de Fundamentos, mas com outra denominação, embora um curso que opte pela docência, com ênfase em pesquisa e gestão, não poderia deixar de conter, no rol das disciplinas obrigatórias, Economia e Educação.

Na análise do processo n. ${ }^{\circ}$ 009279/2007, de 14 de junho de 2007 - Projeto PolíticoPedagógico do Curso de Pedagogia da UFV- 2008, não há nenhuma evidência de interrogação pelo sentido da educação e sua finalidade. Também não são explicitados a concepção de educação e de avaliação, um diagnóstico do curso em nível nacional e local, um diagnóstico das condições materiais e humanas, uma avaliação do projeto político-pedagógico de 2000, para realçar seus pontos fortes e sanar as carências e nem os instrumentos de avaliação do projeto de 2008. Constam, inicialmente, no processo o ofício, datado de 22/06/2007, da Chefe do Departamento de Educação ao Presidente da Câmara de Ensino do Centro de Ciências Humanas, Letras e Artes, e a Ata de n. ${ }^{\circ}$ 161, de 18 de dezembro de 2006, na qual se reapresentaram três propostas de matriz curricular para o curso de Pedagogia e aprovaram-se a nova organização curricular e informes. Mas não consta a cópia da Ata de n. ${ }^{\circ}$ 166, de 21.06.2007, na qual foram aprovados os programas analíticos de 36 disciplinas criadas e de 39 já existentes, que entram na nova organização curricular sem alterações. É impossível discutir e aprovar, em uma única reunião de Colegiado, os programas analíticos de 75 disciplinas; além disso, chama a atenção o fato de não constar no processo nenhuma ata de discussão, análise e aprovação do novo projeto-pedagógico. 
Em 22 de junho de 2007, a chefe do Departamento de Educação enviou o processo ao Presidente da Câmara de Ensino do Centro de Ciências Humanas, Letras e Artes.

Atualmente, a UFV tem quatro Câmaras de Ensino: a do Centro de Ciências Agrárias, a do Centro de Ciências Biológicas e da Saúde, a do Centro de Ciências Exatas e Tecnológicas e a do Centro de Ciências Humanas, Letras e Artes. Cada Câmara é responsável pela gestão didático-pedagógica do ensino de graduação dos cursos por ela oferecidos. Cada Câmara é constituída pelo diretor do Centro de Ciências, pelos coordenadores dos cursos de graduação, vinculados ao Centro, um membro docente da Comissão de Ensino de cada Departamento vinculado ao Centro, um representante docente de cada um dos demais Centros, um representante docente dos cursos de pós-graduação vinculados ao Centro, dois representantes estudantis eleitos pelos seus pares entre os estudantes dos cursos de graduação do Centro. (Resolução n. ${ }^{\text {. }}$ 15/1999, de 22/12/99). Assim a Câmara de Ensino do Centro de Ciências Humanas, Letras e Artes é um grande colegiado, composto pelo diretor do Centro, pelos 14 coordenadores de Curso (Administração, Ciências Contábeis, Ciências Econômicas, Comunicação Social, Dança, Direito, Economia Doméstica, Educação Infantil, Geografia, História, Letras, Pedagogia, Secretariado Executivo e Administração a Distância), por sete docentes membros da Comissão de Ensino dos Departamentos (Administração, Artes e Humanidades, Direito, Economia, Economia Doméstica, Educação e Letras), três representantes docentes dos outros Centros, quatro representantes docentes dos cursos de pósgraduação (Administração, Economia, Economia Aplicada e Economia Doméstica) e dois representantes estudantis, totalizando 31 membros.

Em reunião realizada no dia 02 de julho de 2007, nove dias após o encaminhamento do processo, a Câmara de Ensino do Centro de Ciências Humanas, Letras e Artes aprovou, por unanimidade, a proposta de Projeto Político-Pedagógico do Curso de Pedagogia da UFV, para o ano de 2008. Como não consta do processo supracitado nenhum parecer de relator, deduz-se que o processo constava apenas da pauta e foi apresentado e aprovado, sem análise.

Enviado à Pró-Reitoria de Ensino, nos dias 21/08/2007 e no dia 11/09/2007, foi submetido ao Conselho de Graduação, no dia 20/09/2007, conforme consta da Ata n. ${ }^{\circ} 402$ :

6.1. Processo 009279/2007 - Projeto Pedagógico - Curso de Pedagogia - Comissão Coordenadora do curso de Pedagogia. O conselheiro (...) relatou e prestou esclarecimentos. Após analise, a conselheira (...) propôs aprovar o Projeto Pedagógico do curso de Pedagogia. Colocada em votação, a proposta de aprovar o Projeto pedagógico do curso de Pedagogia com as alterações constantes do processo 009279/2007. 
No que tange aos interesses desta tese, questiona-se: Como se apresentava e como ficou a Filosofia da Educação no projeto pedagógico da Pedagogia?

\subsection{Das disciplinas de Filosofia da Educação}

Pensa-se um curso de graduação com a finalidade de formação para uma área específica, o que pressupõe um projeto de formação geral e de habilitação para o exercício de uma profissão. No caso do curso de Pedagogia, pensa-se um projeto de formação que possibilite ao formando a construção de si e não apenas a internalização de conhecimentos, a aquisição de atitudes, habilidades e técnicas, que se materializa em um projeto-pedagógico ou na construção do currículo.

O primeiro currículo do curso de Pedagogia da UFV data de 1972, pelo qual o aluno deveria perfazer um total de 147 créditos em 2.400 horas-aula, estipulando-se a participação das disciplinas de Filosofia da Educação, num total de quatro disciplinas, denominadas PED 145, PED 146, PED 147 e PED 148, que perfaziam um total de 12 créditos e 180 horas-aula.

Durante a vigência dos Catálogos de Graduação, nos anos de 1972, 1973 e 1974, são ofertadas, nos primeiros semestres letivos do curso de Pedagogia, as quatro disciplinas de Filosofia da Educação, cujas ementas e programas analíticos (Anexo A1), são de responsabilidade do professor Guy Capdeville. Tais disciplinas, oferecidas com três créditos e 45 horas/aula cada, eram encadeadas por sistema de pré-requisito e foram construídas e ministradas pelo próprio professor, durante os mesmos anos.

Ao analisar os Catálogos de Graduação desses referidos anos, observa-se nas ementas e nos programas analíticos das duas primeiras disciplinas um privilégio de conteúdos filosóficos em detrimento do conteúdo filosófico educacional, trabalhando-se em perspectiva de História da Filosofia, Ciência, Metafísica, Ética e Arte.

Nas duas últimas disciplinas, em que se apresentam os fundamentos filosóficos da educação, discutem-se a relação Filosofia e Educação, os fins da educação, o homem como ser educável e ainda as principais correntes filosóficas sobre educação. Trata, ainda, das relações entre totalitarismo e educação e democracia e educação. A disciplina EDU 148, ao referir-se aos problemas filosóficos da educação, recorta aspectos da educação, da inteligência, da vontade, da moral, da religião, da estética e da física. Chamam atenção a perspectiva histórica da filosofia e a fragmentação de aspectos da educação, inclusive no que tange ao cristianismo e educação e à educação moral e religiosa. 
Pensa-se que a abordagem para tais disciplinas assume a internalização dos conteúdos apresentados, e não uma interrogação sobre estes, para oportunizar a construção de um pensamento crítico-reflexivo.

Em 1975, as disciplinas do curso de Pedagogia são renomeadas como EDU, respectivamente, como EDU 145, EDU 146, EDU 147 e EDU-148, com o mesmo número de créditos/carga horária, as mesmas ementas e os mesmos programas analíticos (Anexo A2).

Embora conste no Catálogo de Graduação que essas disciplinas estavam a cargo do professor Guy Capdeville, conforme certidão de aulas ministradas, do Registro Escolar da Universidade Federal de Viçosa, elas foram ministradas pelo professor José Henrique de Oliveira, nos anos de 1975, 1976 e 1977. Destaca-se que, oficialmente, mantêm-se as ementas e os programas analíticos das disciplinas de Filosofia da Educação.

Na edição de 1978, do Catálogo de Graduação (Anexo A3), tais disciplinas são renomeadas como EDU 141, EDU 142 e EDU 143 e EDU 144, sendo a primeira denominada Filosofia, passando a ser ministradas uma disciplina de Filosofia e três de Filosofia da Educação, com quatro créditos e 60 horas-aulas cada. Os programas analíticos das disciplinas de Filosofia da Educação se mantêm, e EDU 148 Filosofia da Educação entra em extinção.

O Catálogo de Graduação da UFV, de 1980 (Anexo A4), evidencia alteração nos programas analíticos e nas ementas das disciplinas de Filosofia e de Filosofia da Educação, mantendo-se os códigos, a carga horária e os pré-requisitos. A primeira disciplina oferecida é Filosofia, abordada em perspectiva histórica e em suas correntes atuais, quais sejam, a Fenomenologia, a Dialética, o Estruturalismo e o Positivismo Lógico.

As três disciplinas de Filosofia da Educação abrangem uma "análise" sobre Filosofia e educação, ideologia e educação, axiologia e educação, práxis e educação e mudança social e educação. Chama atenção o fato de constar, em duas destas disciplinas, uma instrumentalização teórica para filosofar o homem, na qual se toma o homem como consciência que se relaciona, na abordagem personalista e mecanicista. Destacam-se, ainda, as tendências e perspectivas da educação, em que se analisam o essencialismo e o existencialismo em suas relações com a educação. Há ainda, uma reflexão sobre a educação sulamericana e as perspectivas antropológicas da sociedade industrial.

Nos Catálogos de Graduação da UFV, de 1981, 1982, 1983 e 1984, as disciplinas de Filosofia e de Filosofia da Educação mantêm a mesma carga horária, as mesmas ementas e os mesmos programas analíticos do Catálogo de 1980 (Anexo A4).

Em 1988/1989, observa-se, no Catálogo (Anexo A5), que as disciplinas de Filosofia e de Filosofia da Educação são renomeadas como EDU 123, EDU 124, EDU 125 e EDU 126. 
Mantêm-se as mesmas ementas, os mesmos programas analíticos, a mesma carga horária e os pré-requisitos.

Na vigência do Catálogo de Graduação, de 1990/1991 (Anexo A6), há alteração significativa nas ementas e nos programas analíticos das disciplinas de Filosofia e de Filosofia da Educação.

A disciplina EDU 123 - Filosofia busca analisar a produção do homem, ao discutir trabalho, alienação, cultura, linguagem, consciência e humanização; produção, evolução e apropriação do conhecimento; especificidade da Filosofia, sua relação com a ciência e seus ramos e lógicas formal e dialética. Observa-se uma influência da perspectiva de análise marxista, na abordagem da disciplina.

No que se refere às Filosofias da Educação, respectivamente EDU 124, EDU 125 e EDU 126, constata-se, na primeira Filosofia da Educação, a discussão sobre a relação Filosofia e educação e sobre Filosofia da Educação como questionamento radical do processo educativo. Todavia, tal perspectiva de análise se faz com a apresentação das correntes essencialistas e existencialistas da educação e com a perspectiva dialética. Há, ainda, ênfase na educação e no contexto, com análise das relações entre educação e política, educação e valores e ideologias da educação.

Especificamente, a segunda disciplina de Filosofia da Educação apresenta uma visão sistematizada de suas concepções fundamentais e sua vigência. Toma-se a classificação efetivada pelo professor Dermeval Saviani, no texto Tendências e correntes da educação brasileira, e apresenta-se a educação brasileira sob o predomínio das concepções: a humanista tradicional (ideologia católica), no período de 1500 a 1889; a humanista moderna (ideologia liberal), no período de 1889 a 1964; a concepção analítica, no período pós 1964; e a concepção dialética da educação. Da apresentação dessas concepções, deduzem-se as decorrências para a educação. Ressalta-se, nesta disciplina, uma perspectiva historicista, em que se toma a educação brasileira para compreendê-la, segundo uma classificação que tem, na perspectiva dialética, o referencial para análise das concepções anteriores. Elimina-se a possibilidade de uma interrogação ilimitada, pois o limite está dado pela perspectiva marxista e seus princípios.

Isto repercute na terceira Filosofia da Educação, em que se abordam a Ideologia e a educação, e a axiologia e a educação, no período tradicional, na educação nova e na educação progressista.

Tais ementas e programas analíticos têm vigência institucional nos Catálogos de Graduação de 1992/1993, 1994/1995, 1996/1997. 
No Catálogo de 2000 (Anexo A7), vigem um novo projeto político-pedagógico e um novo currículo para o curso de Pedagogia. No que tange à área de Filosofia e Filosofia da Educação, extingue-se a EDU 123 - Filosofia. Ressalta-se que a eliminação desta disciplina introdutória do currículo do curso de Pedagogia representa uma perda significativa, em face da mudança no perfil da clientela do curso, anteriormente oriunda do curso de Magistério, antigo Normal, para agora discentes do segundo grau, atualmente ensino médio, no qual não há oferta de disciplinas de Filosofia e, ou, Filosofia da Educação. Também, alteram-se os códigos das disciplinas EDU 224, EDU 225 e EDU 226, respectivamente, Filosofia da Educação I, II e III, que continuam a ser ofertadas nos períodos iniciais do curso. Há redução na carga horária das disciplinas EDU 224 e EDU 226, em 25\%, e alteram-se as ementas e os programas analíticos. Não há no projeto político-pedagógico do curso de Pedagogia, a elaboração de uma justificativa para tais disciplinas, e elas constam porque a última legislação vigente as tornou obrigatórias.

Em relação às ementas e aos programas analíticos, observa-se que nas disciplinas EDU 224 e EDU 225, respectivamente, Filosofia da Educação I e II, que somam 7 créditos e 105 horas/aula, há quase exclusivamente conteúdos filosóficos, exceto pelo tópico Filosofia e educação, onde se discutem cultura e natureza, formação e dever-ser. Os outros tópicos são passagem do mito ao logos e antiguidade clássica; razão e fé, humanismo, racionalismo e empirismo (EDU 224), revolução científica e modernidade; política e educação, no século XVIII; referências da obra de Marx (Idealismo alemão, socialismo utópico e economia clássica) e referências e embates do século XX (Marxismo, Positivismo e Fenomenologia).

A outra disciplina, Filosofia da Educação III, é oferecida com três créditos e 45 horas/aula e aborda as diferentes perspectivas filosóficas e sua vigência no Brasil, além de trabalho e educação, educação como prática social, educação e cidadania.

Constata-se que no Catálogo de Graduação de 2000, que vige até 2008, há privilegiamento de conteúdos históricos da Filosofia, em detrimento dos conteúdos filosóficos educacionais, que quando são abordados, como é o caso da disciplina EDU 226 - Filosofia da Educação III, também o são numa perspectiva histórica: concepção humanista tradicional e moderna, concepção tecnicista ou analítica e concepção dialética e transformadora.

Esse projeto pedagógico vige até a reformulação do curso de Pedagogia, que ocorre em 2006/07, por força da Resolução CNE/CP n. ${ }^{\circ}$, de 15 de maio de 2006. Portanto, reproduzem-se nos Catálogos de Graduação, de 2002, 2003, 2004, 2005, 2006 e 2007, a mesma grade curricular, as mesmas ementas e os mesmos programas analíticos. 
Na edição de 2008, do Catálogo de Graduação (Anexo A8), vige um novo projeto político-pedagógico. No currículo do curso são oferecidas, agora, apenas duas disciplinas de Filosofia da Educação (EDU 224 e EDU 225), com 4 créditos e 60 horas/aula cada, em sistema de pré-requisito. Extinguiu uma Filosofia da Educação - EDU 226 - com 3 créditos e 45 horas/aulas, que analisava as diferentes perspectivas filosóficas e sua vigência no Brasil.

Ao comparar os programas analíticos e as ementas das disciplinas de Filosofia da Educação nos projetos pedagógicos de 2000 e de 2008, a primeira impressão é de que pouca ou nenhuma alteração ocorreu no conteúdo das disciplinas.

.Um primeiro destaque refere-se à redução no número de disciplinas, de três para duas, e, consequentemente, de carga horária, de 150 para 120 horas-aula, o que tem implicações na qualidade e na quantidade de conteúdos. Observa-se que o conteúdo da disciplina extinta foi incorporado na Filosofia da Educação II. Como manter, em 2008, os conteúdos programados em 2000, se se extinguiu uma disciplina e reduziu-se em 30 horas-aula o tempo das disciplinas?

Além disso, pelo menos oficialmente constam do programa analítico o tópico Filosofia e Filosofia da Educação, o pensamento educacional grego e a explicitação, pela primeira vez, dos tópicos: o Empirismo, o Racionalismo e o Idealismo e suas relações com a educação. Mas, considerando a formação acadêmica - Filosofia - de quem elaborou os programas e ementas, nenhuma garantia se tem de que a educação seja objeto de reflexão filosófica.

Embora as ementas e os programas analíticos tenham que ser aprovados pela UFV para se instituírem, isto não garante que eles serão cumpridos. Pode e acontece de o professor ministrar outros conteúdos diferentes dos oficiais, pois não existe nenhum mecanismo de controle para tal.

Da análise dos programas analíticos evidenciaram-se, no período de 1972 a 2008, apenas quatro reformulações nos programas analíticos das disciplinas de Filosofia da Educação, no curso de Pedagogia da UFV, em 1980, 1990, 2000 e 2008. Em 36 anos, apenas três reformulações foram efetivadas, se se levar em conta que, em 2008, ocorreu a absorção de uma disciplina por outra.

Pensa-se que a reformulação dos programas analíticos em 1979, que passam a vigorar no Catálogo de Graduação de 1980, é tributária da contratação de dois novos professores que assumem as disciplinas em 1978 e 1979 e de suas formações: graduação em Pedagogia e mestrado em Filosofia da Educação, graduação em Pedagogia e Filosofia e mestrado em Educação. 
No que diz respeito às alterações dos programas analíticos concretizadas em 1989 e que vigoram no Catálogo de Graduação de 1990, elas não podem ser atribuídas à contratação de novos professores, pois a única alteração que há, no quadro destes é o pedido de dispensa de uma professora. Os outros dois professores, que se responsabilizaram por ministrar as disciplinas de Filosofia da Educação no período de 1985 a 1990, doutoraram-se em 1985. Não há como pensar que, somente após cinco anos de conclusão do doutorado, este se refletiria na estruturação dos programas analíticos das disciplinas. Talvez esses professores só tenham alterado os programas analíticos em 1989, como forma de contribuir e marcar sua história na instituição, às vésperas de suas aposentadorias, em 1991.

Em 1999, é elaborado e aprovado um novo projeto político-pedagógico para o curso de Pedagogia, que passa a vigorar em 2000. Até esse momento, as disciplinas de Filosofia da Educação, isto é, no período de 1992 a 1999, estavam a cargo de dois professores - Marilene de Melo Vieira e Willer Araújo Barbosa, e contaram com a contribuição de Célia Regina Vendramini, no segundo semestre de 1992, que ministrou uma Filosofia da Educação; de Marly Silva de Melo/Eneida Pereira Gondim, no primeiro e segundo semestre de 1993, com uma disciplina em cada; de Maria das Graças Marcelo Ribeiro, no segundo semestre dos anos de 1994 e 1995, com uma disciplina em cada, de Denílson Santos Azevedo, no segundo semestre de 1996, que dividiu uma disciplina com Willer; e de Dileno Dustan Lucas de Souza, que assumiu uma disciplina no segundo semestre de 1998.

No projeto político pedagógico de 2000, as alterações nas disciplinas de Filosofia da Educação se processam na extinção de uma disciplina; na redução de carga horária de duas outras que passam a ser de 45 horas/aulas, mas é, sobretudo, nos programas analíticos, nas ementas, nas unidades e nos assuntos que as disciplinas assumem outra perspectiva - a da História da Filosofia, nas duas primeiras disciplinas, e da história das perspectivas filosóficas da educação, na terceira. Os programas analíticos foram elaborados pelo professor Willer Araújo, que, em 2001, inicia sua licença para doutoramento, momento em que as disciplinas passam a ser ministradas, no geral, por professores substitutos, conforme Anexo C. Em 2005, o professor Willer Araújo retorna do doutorado e assume todas as disciplinas de Filosofia da Educação.

Em 2006, o Conselho Pleno do Conselho Nacional de Educação, por meio da Resolução do Conselho Nacional de Educação/Conselho Pleno - CNE/CP n. ${ }^{\circ}$ 01, de 15 de maio de 2006, institui as Diretrizes Curriculares Nacionais para o Curso de Graduação em Pedagogia, licenciatura, que determina a elaboração de novo projeto pedagógico, em conformidade com o prescrito na resolução supracitada e o seu protocolo no órgão 
competente do respectivo sistema de ensino, o que, no caso da UFV, implicam a tramitação no Colegiado do Departamento de Educação, na Câmara de Ensino do Centro de Ciências Humanas, Letras e Artes e no Conselho Técnico de Graduação/Pró-Reitoria de Ensino.

Em 18 de dezembro de 2006, em reunião do Colegiado Ampliado do Departamento de Educação (além da participação dos docentes e dos dois representantes discentes, estavam também, um representante discente do primeiro, do terceiro e do quinto período do curso de Pedagogia, dois egressos, um representante da $33^{\text {a }}$ Superintendência Regional de Ensino de Ponte Nova e um representante do Sindicato Único dos Trabalhadores em Educação de Minas Gerais em Viçosa), aprovou-se a nova matriz curricular para o curso de Pedagogia da UFV.

Nessa nova matriz curricular, as disciplinas de Filosofia da Educação foram reduzidas a apenas duas, oferecidas no $1 .^{\circ}$ e $2 .^{\circ}$ períodos do curso, concatenadas entre si por prérequisito. Assim, extinguiu-se uma disciplina e reduziu-se em 30 horas/aula o tempo das Filosofias da Educação. Têm-se, na nova matriz curricular, duas Filosofias da Educação, com 60 horas/aula cada, e. alterações dos programas analíticos.

Na Filosofia da Educação I, permanecem as três unidades. A primeira unidade Filosofia e Filosofia da Educação contempla três subitens: sentimento da educação na cultura ocidental, que não se consegue traduzir em conteúdo, mas que se especula ser talvez o modo como a cultura ocidental compreende e significa a educação; atitude filosófica e identidade da Filosofia da Educação. Todavia, não há, nas referências bibliográficas, nenhuma literatura que discuta a identidade da Filosofia da Educação. A segunda unidade permanece como no programa analítico de 2000; a terceira engloba o Empirismo, o Racionalismo e o Idealismo, como em 2000, agora acrescido do Cristianismo. Destaca-se, contudo, que, pela primeira vez, se mencionam as suas relações com a educação. Ressalte-se que a perspectiva histórica continua como marca da elaboração do programa.

A Filosofia da Educação II é uma composição das Filosofias da Educação II e III, do Catálogo de 2000. Ela contempla quatro unidades com 15 horas/aula cada. A primeira referese ao que constituía o conteúdo da Filosofia da Educação II, no Catálogo de 2000, agora reduzida apenas à análise do positivismo e do marxismo, acrescido das suas relações com a educação. A unidade dois é a transposição da Filosofia da Educação III, do Catálogo de 2000 - diferentes perspectivas filosóficas da educação no Brasil, acrescido da expressão histórica da Filosofia da Educação na cultura ocidental e da educação como prática social. Mantém-se a perspectiva histórica. A terceira é abordagem filosófica da relação entre educação, cultura e valores; e a quarta refere-se à Formação Ética e Formação Política na qual se discutem a Filosofia e a questão dos valores, a questão moral da educação e Filosofia e Política. As 
referências bibliográficas compõem-se, sobretudo, de obras de John Dewey (20\%), Paulo Freire (20\%), Freinet (6,6\%), Escola de Frankfurt (13,3\%), Filosofia (6,6\%), ética e moral $(26,6 \%)$ e apenas uma $(6,6 \%)$, a Filosofia da Educação, de Antonio Joaquim Severino.

Pensa-se que a estrutura e o conteúdo das disciplinas de Filosofia da Educação, como estão organizados, não potencializam a interrogação. Considerando que a formação de professores para a educação infantil e magistério das séries iniciais se fará nos cursos de Pedagogia e nos Institutos Superiores de Educação, cuja concepção é ainda mais tecnicista, interroga-se: a Filosofia da Educação, como historicamente tem se apresentado, possibilita ao pedagogo construir-se como uma subjetividade reflexiva deliberante, deixando de ser produto de sua psique, de sua história e da instituição que o formam? Pensa-se que não, e esta é a justificativa deste trabalho.

Por isso, destaca-se, no Anexo B, a Formação acadêmica dos professores de Filosofia e de Filosofia da Educação.

Do total dos 21 professores, 1 tem formação em Filosofia e Letras; 3, em Filosofia; 3, em Filosofia e Pedagogia; 10, em Pedagogia; 1, em Comunicação Social e Pedagogia; 2, em Ciências Sociais; e 1, em História. Destes, 4 eram professores substitutos, com formação acadêmica: 1 em Filosofia e 3, em Pedagogia. Cumpre salientar que os concursos no Departamento de Educação da UFV explicitavam, nos seus Editais para a área de Fundamentos - Filosofia, Sociologia e História da Educação, a exigência de graduação, ou seja, em Pedagogia ou Filosofia ou áreas afins.

No período de 1972 a 2005, 11 professores fizeram seus cursos de pós-graduação: quatro fizeram mestrado; dois, mestrado e doutorado; cinco, doutorado; e um se encontrava em doutoramento, o que implicou remanejamento de professores dentro da área de fundamentos e contribuição de outras áreas para cumprir a oferta das disciplinas de Filosofia e Filosofia da Educação. Outro fato é a contratação temporária de quatro professoressubstitutos, com vistas em suprir carência de docentes, em face do treinamento de professores em pós-graduação e do volume de oferta de disciplina pelo Departamento de Educação, não só do curso de Pedagogia, mas também de outros cursos de licenciatura e bacharelado da UFV.

Dos 17 professores efetivos que ministraram disciplinas de Filosofia/Filosofia da Educação, no curso de Pedagogia, 10 foram admitidos na Instituição, no período de 1962 a 1980, por meio de Contrato Individual de Trabalho. Neste, não havia especificação da área de contratação e atuação. Os outros sete foram admitidos, no período de 1991 a 2002, em 
concurso para Filosofia e História da Educação - 02; História, Filosofia e Sociologia da Educação - 03; Fundamentos da Educação - 01; e Administração Escolar - 01.

Partindo do princípio de que o fazer universitário implica ensino, pesquisa e extensão, buscou-se identificar os investimentos dos professores em ensino e pesquisa.

Ao consultar o banco de dados de ensino da UFV - http://www.cpd.ufv.br/ensino, pode-se atribuir os créditos aos que ministraram as disciplinas de Filosofia e Filosofia da Educação no curso de Pedagogia, conforme Anexo C.

Ao entender que a pesquisa é inerente ao fazer universitário, tanto como forma de permanentemente refletir sobre sua própria prática, tanto como forma de apropriação e produção de conhecimento, buscou-se explicitar os investimentos em pesquisa pelos professores que ministraram as disciplinas, objeto de estudo.

Para tal, buscou-se no Sistema Gestor de Pesquisa da UFV http://cpd.ufv.br/pesquisa, as linhas de pesquisa do Departamento de Educação, o responsável na Instituição pelo oferecimento dessas disciplinas.

Ao pesquisar o número de projetos de pesquisa, registrados na Pró-Reitoria de Pesquisa e Pós-Graduação (PPG), nas nove linhas de pesquisa que existiam no Departamento de Educação, têm-se: Alfabetização - 06; Ensino e Aprendizagem - 10; Currículo - 18; Educação e Sociedade - 112; Educação de Jovens e Adultos - 10; Formação de Professor 71; Filosofia - 04; Fundamentos da Educação - 10; e Educação Especial - 10. Dos projetos registrados na linha de Fundamentos da Educação, apenas um em Filosofia da Educação e, na linha de Filosofia, três. Contudo, no Sistema Gestor de Pesquisa, identificaram-se 07 projetos. Tal fato se justifica pela inexistência das linhas de pesquisa de Filosofia e de Fundamentos da Educação, que só posteriormente foram criadas. Assim, projetos dessa linha de pesquisa foram enquadrados em Currículo - 1; Formação de Professores - 1 e Direitos Especiais - 1 . $\mathrm{Na}$ linha de pesquisa Filosofia estão registrados 03 projetos e 01 em Fundamentos da Educação.

Ao pesquisar, ainda, no Sistema Gestor de Pesquisa, sobre os professores que estão em efetivo exercício, tem-se o total de projetos de cada um, seja como líder ou membro: Denílson Santos de Azevedo - 16; Dileno Dustan Lucas de Souza - 22; José Henrique de Oliveira - 00; Maria das Graças Marcelo Ribeiro - 16; Marilene de Melo Vieira - 17; Rosimar de Fátima Oliveira - 03; e Willer Araújo Barbosa - 14.

Com a aprovação da pós-graduação stricto sensu (mestrado), as linhas de pesquisa foram reestruturadas: Formação de professores e práticas educativas e Educação, Estado e Sociedade. 
Na PPG, os projetos de pesquisa são classificados em Autônomos, Institucional, Interinstitucional, Subprojeto e de Treinamento. Os projetos de treinamento englobam iniciação científica, mestrado, doutorado, aperfeiçoamento e pós-doutorado. Assim, dos setes projetos de pesquisa registrados, 04 são de treinamento (iniciação científica) e 03, autônomos.

Constituído na década de 90, o Sistema Gestor de Pesquisa só tem dados posteriores ao ano de 1992. Como a existência do Departamento é da década de 70, ter-se-ia uma lacuna de 20 anos, em que não se disporia de dados. Esse foi o motivo pelo qual se buscou na Plataforma Lattes/CNPq - Conselho Nacional de Desenvolvimento Científico e Tecnológico - a produção bibliográfica de todos os 17 professores pesquisados, conforme anexo IV Professores de Filosofia/Filosofia da Educação na UFV - investimentos em pesquisa. Salienta-se que o levantamento dos dados tomou como critério o vínculo com a UFV, isto é, a produção durante o tempo que esteve na instituição.

Os dados do Anexo D podem ser resumidos nos indicadores: n. ${ }^{\circ}$. de projetos de pesquisa - 61; livros publicados -13; capítulos de livros - 11; artigos em periódicos - 43; trabalhos em congresso - 98; resumos em congressos - 151; artigos em periódicos de Filosofia/Filosofia da Educação - 01; trabalhos em congressos/Filosofia/Filosofia da Educação - 05; resumos em congressos/Filosofia/Filosofia da Educação - 19.

Ao buscar sanar a lacuna dos dados do Sistema Gestor de Pesquisa/UFV, no período de 1970 a 1992, acessou-se http://www.cpd.ufv.br/publicacao, Pró-Reitoria de Planejamento e Orçamento - Publicações envolvendo docentes da UFV, em 03/11/2009. Nesta página foi possível acessar as publicações por docente-autor, responsável por ministrar disciplinas de Filosofia e Filosofia da Educação no curso de Pedagogia. Um problema é que a página ainda esta em elaboração, e os dados apurados referem-se a toda publicação, sem especificá-la. Todavia, ao analisar os relatórios, emitidos para cada um dos docentes, pode-se aferir, conforme Anexo E - Publicações envolvendo docentes da UFV que ministraram as disciplinas filosofia e filosofia da educação, que os seis docentes que atuaram na UFV, nas décadas de 70 e 80 e que se desligaram desta no início da década de 90, foram responsáveis por um total de 60 publicações, correspondendo a 7,33\% da produção. Os outros 17 professores foram responsáveis por 758 publicações, correspondendo a 92,66\%. Do total de 818 produções bibliográficas, 25 referem-se à Filosofia e à Filosofia da Educação. São eles: Filosofia - 01 capítulo de livro; 08 artigos e 07 resumos; Filosofia da Educação - 01 livro organizado e 08 resumos. Deste total de 25 publicações, apenas um é de autoria de professor contratado na década de 70 e 80. 
Ao observar a produção registrada pelos professores após se desligarem da UFV, levanta-se a hipótese de que a atividade de pesquisa, no Departamento de Educação/UFV, não se constituía prioridade. Salienta-se também, que os 06 professores concursados na área prestaram exame em Filosofia e História da Educação - 02; História, Filosofia e Sociologia da Educação - 03; Fundamentos da Educação - 1, mas, apenas dois têm produção bibliográfica em Filosofia e em Filosofia da Educação.

\subsection{As representações e os pensamentos dos ufevianos sobre a Filosofia da Educação}

O que representam ou o que pensam os professores e os dirigentes acadêmicos da UFV sobre a disciplina Filosofia da Educação no Curso de Pedagogia? O que representam e pensam constituem o mundo privado (kosmos idios), mas enraizado na instituição socialhistórica, no mundo comum (Kosmos Koinos).

Para Castoriadis (1982):

Os dois percursos são pois essenciais, inelimináveis, irredutíveis, indissociáveis.
Aquele que, a partir da idiogênese e da koinogênese, mostra o enraizamento da
coisa, da percepção, do mundo, da lógica, do pensamento, ao mesmo tempo no
magma representativo da psique e na instituição social-histórica; portanto que coisa,
mundo, indivíduo, pensamento, significação são instituições e sedimentaçôs de
instituições, que devem também, e ao mesmo tempo, ser trazidas pelo fluxo
representativo dos sujeitos para poderem existir e operar; que, do momento em que
pensamos-falamos, não há "antes" que possamos pensar-dizer, que só do meio
destas instituiçães sucessivas e a partir delas podemos pensar-falar - de tal maneira
que não existe jamais tabula rasa possível, dúvida generalizada ou fundamento
primeiro, e que a pesquisa das condições da palavra e do pensamento nunca pode ser
radical, já que não pode abstrair-se destes, nem questioná-los, a não ser
confirmando-os. E o percurso que volta incansavelmente a todos os pontos para
questioná-los de outra maneira, que compara o há de há representação com o há de
há coisa, que nas e pelas diferenças e as alteridades dos mundos privados e dos
mundos sociais-históricos tenta visar uma significação mundo e um mundo, tenta
por à prova sua instituição e toda instituição dada e, nos casos mais favoráveis, só
atinge o ponto em que se cristaliza uma nova instituição, mas também. Âs vezes, o
ponto de partida de um outro percurso interminável que questionará a instituição de
outra maneira.
Cada um destes percursos conduz ao outro absolutamente; cada um está, por todo
lado, densamente no outro. E sua relação não pode ser denominada nem antinomia,
nem complementaridade, nem circularidade; ela é o que é, modelo de si mesma,
pensável a partir de si mesma. Ela é o modo de ser do pensamento como pensamento
histórico e como fazer pensante. (p. 383).

O estudo da origem e desenvolvimento das funções psíquicas e o estudo sobre a formação da sociedade são perspectivas irredutíveis, inseparáveis e inelimináveis. Se o indivíduo, que é psique, cria a sociedade e é por ela criado, só se pode compreender a(s) 
representação(ões) dos indivíduos simultaneamente no magma representativo da psique e no social-histórico, isto é, no mundo privado e no mundo comum. A emergência da percepção e da coisa pelo indivíduo só pode ser pensada, portanto, no entrelaçamento das perspectivas psicogenética e sociogenética.

Falar, pois, de coisa, mundo, indivíduo, pensamento, significação é falar de instituições que só podem existir e operar, se compuserem o fluxo representativo do indivíduo, o que se dá no processo de socialização. Assim, é só por meio das instituições que se pode pensar-falar. Nesse processo, desempenha papel sine qua non a instituição linguagem como instrumento de comunicação entre consciências e da consciência consigo mesma. Sem a linguagem,

[...] a imaginação jamais poderia tornar-se pensamento, se os esquemas e as figuras que ela faz serem permanecessem simplesmente presos na indefinidade do fluxo representativo, se não se "fixassem" e não se "estabilizassem" em "suportes" materiais-abstratos $\{\ldots]$, para resumir, sigmos. (CASTORIADIS, 1982, 381)

Mas a linguagem não se reduz aos signos, à dimensão código. Ela é também, dimensão significativa da língua. Ainda para esse autor:

Uma língua só é língua na medida em que novas significações, ou novos aspectos
de uma significação, podem sempre nela emergir, e emergem constantemente;
como já foi dito mais acima, isso não é um aspecto "diacrônico", mas propriedade
essencial da língua enquanto totalidade "sincrônica". Uma língua só é língua na
medida em que oferece aos locutores a possibilidade de se localizar em e por aquilo
que dizem para aí moverem-se, de se apoiar no mesmo para criar o outro, de
utilizar o código das designações para fazer aparecer outras significações ou outros
aspectos das significações aparentemente já dados. (CASTORIADIS, 1982, p. 398).

A língua é, portanto, o que abre para o indivíduo a possibilidade de construção do mundo privado em interface com o mundo comum. É ela que viabiliza a ideia de pertencimento ao social-histórico, o participar no que está instituído e a criação. Permite, também, o representar e o fazer pensante. Este é constituído de "uma mistura onde as partes de atividades não conscientes e conscientes são indissociáveis, como o são também as partes de atividade espontânea e deliberada.” (CASTORIADIS, 1992, p. 226). Isso leva a conceber o pensar como:

Sempre também necessariamente colocar em movimento, em certas direções e segundo certas regras (não necessariamente controladas, nem umas nem outras), representações: figuras, esquemas imagens de palavras - e isso não é nem acidental, nem condição exterior, nem apoio, mas o próprio elemento do pensamento. (CASTORIADIS, 1982, p. 373)

E são essas elaborações teóricas que permitirão tentar compreender como um grupo de professores e de dirigentes acadêmicos da UFV, que ministraram e aprovaram as disciplinas Filosofia da Educação na Instituição, as representavam e pensavam. 
O grupo foi selecionado para entrevista, em função dos critérios de ministrar as disciplinas; elaborar os programas analíticos destas e coordenar colegiados aos quais os programas analíticos foram submetidos e aprovados para vigirem na Instituição.

Como o Curso de Pedagogia foi criado na UFV na década de 1970, o período que se buscou compreender foi o correspondente às décadas de 1970, 1980, 1990 até o ano de 2008.

A Universidade Federal de Viçosa, em 1978, com a Portaria n ${ }^{\circ} 231$, de 13 de março de 1978, cria as Pró-Reitorias Acadêmica, de Administração e de Assuntos Comunitários.

A Pró-Reitoria Acadêmica (PAC) iniciou suas atividades em 1979, pela Portaria $\mathrm{n}^{\circ}$. 874/79, de 29 de outubro de 1979. A ela estavam vinculados o Conselho de Graduação, o Conselho de Pós-Graduação, a Biblioteca Central, o Colégio Universitário e o Registro Escolar. Sua atribuição era a coordenação geral das atividades de ensino de graduação, de pós-graduação e ensino de $2^{\circ}$ grau não profissionalizante. Em 10 de agosto de 1982, foram também vinculados à PAC os Centros de Ciências Agrárias, Biológicas e da Saúde, Exatas e Tecnológicas e Humanas, Letras e Artes e o Conselho de Extensão. Pela Portaria no 790/86, de 08 de julho de 1986, a PAC foi responsabilizada pela coordenação das atividades de ensino, pesquisa e extensão. Vincularam-se ainda a ela a Unidade de Apoio Educacional e a Assessoria de Assuntos Internacionais.

Outra reestruturação ocorreu na UFV em 1996, por meio da Resolução 14/96 CONSU (Conselho Universitário), de 20 de setembro de 1996 e da Portaria no 389/97, de 24 de março de 1997. Criou-se a Pró-Reitoria de Ensino (PRE), fundindo na mesma a PróReitoria Acadêmica e o Conselho Técnico de Graduação. Estavam a ela subordinados o Colégio Universitário, a Divisão de Vestibular, a Diretoria de Registro Escolar, a Comissão de Avaliação de Disciplinas e a Unidade de Apoio Educacional.

Atualmente, vinculam-se à PRE a Diretoria de Registro Escolar, a Diretoria de Vestibular e Exames, a Diretoria de Programas Especiais, a Secretaria Geral de Graduação e o Colégio de Aplicação-CAP-COLUNI.

No período que interessa, a estrutura administrativa dos cursos de graduação da UFV, na década de 1970, era composta pelo Conselho de Ensino, Pesquisa e Extensão (CEPE), de 1972, e pelo Conselho de Graduação, de 1972. Em 1980, mantêm-se o CEPE e o Conselho de Graduação e criam-se a Pró-Reitoria Acadêmica, em 1979, e a Coordenação de Curso, em 1989. Na década de 1990, ocorre outra reestruturação, criando-se a Pró-Reitoria de Ensino (PRE). Assim, a elaboração e, ou, reelaboração de programas analíticos de disciplinas tramitavam pelo Departamento de Educação, responsável pelo oferecimento do curso como iniciativa do seu professor; pelo Centro de Ciências Humanas, Letras e Artes/Câmara 
Curricular do Curso, posteriormente transformada em Câmara de Ensino, em 29 de novembro de 1999, pela Resolução 01/99, do CEPE, e pelo Conselho de Graduação. Até 26 de agosto de 1997, os programas analíticos tinham também de ser submetidos ao CEPE. Com a Resolução n 14/97, o CEPE delegou ao Conselho de Graduação a decisão sobre a criação, denominação, funcionamento, extinção de programas analíticos e distribuição de disciplinas de graduação.

Dos dirigentes acadêmicos da UFV priorizaram-se os que na época - 1980, 1990, 2000 e 2008 -, em que ocorreram mudanças nos programas analíticos das disciplinas de Filosofia da Educação ministradas no Curso de Pedagogia, ocupavam os cargos do Conselho Técnico de Graduação, de Diretor do Centro de Ciências Humanas, Letras e Artes e de Coordenador do Curso. Foram entrevistados como Presidente do Conselho de Graduação Oderli de Aguiar; como Pró-Reitor de Ensino Frederico José Vieira Passos; como Diretores do Centro de Ciências Humanas, Letras e Artes Adriel Rodrigues de Oliveira e Walmer Faroni; e como Coordenador do Curso de Pedagogia José Henrique de Oliveira.

Dos administradores, atenderam à entrevista um pró-reitor de Ensino, um presidente do Conselho de Graduação, dois diretores do Centro de Ciências Humanas, Letras e Artes e um coordenador do curso de Pedagogia.

Dos que não aceitaram a entrevista, as justificativas foram: o pró-reitor de Ensino alegou problemas de saúde na família e indisponibilidade de tempo; o presidente do Conselho de Graduação - gestão 22/03/1978 a 07/12/78 - alegou não ter competência para responder à entrevista, pois não conhecia nada da disciplina de Filosofia da Educação; o diretor do Centro de Ciências Humanas, Letras e Artes - gestão 78/82 e 89/73 - que coordenou a aprovação de duas das reformas dos programas analíticos das disciplinas, em 1980 e 1990, alegou que há muito se desligou da Universidade e não teria disponibilidade para a entrevista; a coordenadora do Curso de Pedagogia - gestão 1999/2001 -, que coordenou a grande reforma do Curso em 1999, também não se disponibilizou, justificando estar com muitos compromissos e não ter como priorizar essa atividade.

Eis o que pensavam os dirigentes acadêmicos da UFV sobre a Filosofia da Educação:

Para outros cursos, como as Engenharias por exemplo, eu concordo com a posição de um Filósofo, professor da UNICAMP, que acha que Filosofia deve ser tratada em todas as disciplinas e não existir uma disciplina independente. Entretanto, para o curso de Pedagogia, acho um tema indispensável, devendo ser tratado com disciplina independente e também nas demais disciplinas.

(Depoimento do Pro-Reitor de Ensino - gestão 1997-2000).

Um importante instrumento para a análise preliminar e maior clarificação do conceito de educação, particularmente para aqueles que, brevemente, serão profissionais dessa área. (Depoimento do Presidente do Conselho de Graduação gestão 1988-19992). 
Considero a disciplina Filosofia da Educação como um dos conteúdos de maior relevância no conjunto dos conhecimentos que devem formar o acervo intelectual do Pedagogo. A reflexão sobre a natureza da Educação, sobre a importância relativa dela na reprodução/mudança da estrutura social, sobre a importância do conhecimento no mundo do trabalho e na produção social de bens e serviços, assim como sobre o papel da escola e do educador na formação da cidadania deve ser uma capacidade desenvolvida na disciplina e que muito vai auxiliar o pedagogo. (Depoimento do Diretor do Centro de Ciências Humanas, Letras e Artes - gestão 2002-2004).

Tem capital importância na formação do educador de modo geral. (Depoimento do diretor do Centro de Ciências Humanas, Letras e Artes - gestão 2006-).

Penso ser relevante e importante para todo o curso, em especial para a área de fundamentos. (Depoimento do Coordenador do curso de Pedagogia - gestão 20042009)

Dessa forma, a disciplina é pensada como reflexão, como instrumento para clarificação do conceito de educação. Ela é assumida, como indispensável, relevante e importante para todo o curso. Ressalta-se no depoimento do pró-reitor de Ensino - gestão 1997-2000 - a questão de que a Filosofia deva ser tratada em todas as disciplinas e não existir como disciplina independente e de que a Filosofia da Educação é um tema que deve ser tratado em disciplina independente e também nas demais disciplinas. Dizer que a Filosofia deva ser tratada em todas as disciplinas e não existir como uma, é desconhecer a especificidade da Filosofia. Ainda, dizer que a Filosofia é um tema a ser tratado em disciplina específica e também nas demais disciplinas é desconhecer o que é Filosofia da Educação como campo do conhecimento. Também querer que esse tema seja tratado nas demais disciplinas é não ter conhecimento da especificidade dos campos de conhecimento do Curso de Pedagogia, que se materializam em disciplinas.

Assumir que a disciplina seja "instrumento para análise preliminar e maior clarificação do conceito de educação" significa reduzir a Filosofia da Educação à análise da linguagem, do conceito de educação.

Chama a atenção o fato de ter se tornado lugar-comum, nos cursos de formação de professores, na Pedagogia, dizer que a Filosofia da Educação é análise, reflexão e crítica sobre a Educação. Assim, quanto mais se assumiu esse discurso, este chavão, menos análise, menos reflexão e menos crítica foram efetivadas.

No que se refere ao papel atribuído à disciplina, tem-se:

Indispensável na formação de um Educador. (Depoimento do pró-reitor de Ensino gestão 1997-2000).

Um importante instrumento introdutório à discussão e aprofundamento da teoria educacional e, por conseguinte, da prática educacional, particularmente o estudo e a crítica de nosso ambiente educativo. (Depoimento do presidente do Conselho de Graduação - gestão 1988-1992). 
[...] equipar o pedagogo com um acervo de conhecimentos sobre a educação e sobre o pensamento educacional que lhe permita refletir crítica e criativamente sobre seu trabalho, sobre a instituição escola em seu papel social e sobre o sistema educacional - seu papel, estrutura, resultados e impactos - do país. (Depoimento do diretor do Centro de Ciências Humanas, Letras e Artes - gestão 1997-2001).

Análise e reflexão profunda sobre a educação. (Depoimento do Diretor do Centro de Ciências Humanas, Letras e Artes - gestão 2006-).

Além de trabalhar na fundamentação teórica, trata-se de um exercício permanente de ir às raízes de todas as questões, além de oportunizar uma análise (racional) sobre a vida (de um modo geral). (Depoimento do Coordenador do curso de Pedagogia - gestão 2005-2009).

Vê-se que o pensamento dos dirigentes acadêmicos sobre o papel da disciplina Filosofia da Educação, a expressam como: instrumento introdutório para análise da teoria educacional; equipagem do pedagogo, com acervo de conhecimentos sobre a educação e o pensamento educacional; análise e reflexão; fundamentação teórica; busca das raízes das questões; e análise racional sobre a vida.

Observa-se, ainda, a influência do Professor Saviani (1982) na resposta - ir às raízes das questões. Para ele, a Filosofia é uma reflexão que deve satisfazer as exigências da radicalidade, do rigor e da globalidade.

Inquiridos sobre a participação na construção da identidade das disciplinas de Filosofia da Educação, do Curso de Pedagogia da UFV, a quase totalidade dos dirigentes disse não ter condições de responder. Apenas o coordenador do Curso de Pedagogia manifestou sua participação em três momentos: “como professor de tais disciplinas por alguns anos e períodos curriculares, Coordenador do Curso de Pedagogia e presidente dos trabalhos que culminaram com a reestruturação do curso de Pedagogia, conforme as DCNs/2006". Todavia, essas participações em nada contribuíram para a identidade das disciplinas: primeiro porque, enquanto professor destas, ele assumiu os programas analíticos, que haviam sido elaborados pelo Professor Guy Capdeville; segundo porque, como coordenador do Curso gestões 13/05/2005 a 13/05/2007 e 14/05/2007 a 26/01/2009 -, ele não teve interferência nos programas analíticos que foram reformulados em 2007 pelo Professor Willer Araújo Barbosa; e terceiro porque, como presidente da reformulação do curso, por decorrência do cargo de seu coordenador, também não interferiu em nada.

No que se refere aos professores que ministraram as disciplinas de Filosofia da Educação, em número de 17, 10 responderam à entrevista, um não foi localizado (Adelino Massarolo), dois não responderam (Lucio Kreutz e Lucíola Licinio de Castro Paixão Santos), duas não foram contactadas (uma estava enfrentando sérios problemas de saúde (Marly Silva 
de Melo) e a outra pelo tempo efêmero na instituição, durante o qual, inclusive, estava em treinamento (Célia Regina Vendramini)), um era falecido (Guy Capdeville) e uma como autora deste trabalho, mas também professora da disciplina, que se eximiu da entrevista. Os professores substitutos, em número de quatro, não foram entrevistados.

Perguntados se a formação acadêmica viabilizava sua atuação como professor de Filosofia da Educação, 07 dos 10 se manifestaram afirmativamente:

Sim. Considerando toda a formação acadêmica em nível de graduação e pósgraduação. Graduação - Pedagogia e Filosofia. Mestrado - Planejamento da Educação (Professor José Henrique de Oliveira).

Creio que sim, uma vez que o Mestrado e o Doutorado estão focados na área de Filosofia da Educação. (Professor José Fagundes).

(Sim, porque possuo) Mestrado em Filosofia da Educação e Doutorado em Filosofia e História da Educação. (Professora Olinda Maria Noronha).

Sim, porque o estudo da Filosofia implica em seu ensino, assim a educação da filosofia torna-se também filosofia da educação. (Professor Willer Araújo Barbosa).

Nossa formação generalista nos garante tal capacidade. (Professor Dileno D. L. de Souza).

Porque o núcleo básico do currículo do curso de Pedagogia que cursei estava centrado em Filosofia da Educação. (Professor José Carlos Costa).

Sim. Tenho Registro "L" para lecionar Psicologia, Filosofia e Sociologia. (Professora Eneida Pereira Gondim).

Os outros 03 professores assim se posicionaram:

Parcialmente, uma vez que não aborda especificamente a Filosofia, nem a Filosofia da Educação. (Professora Rosimar de Fátima Oliveira)

Em termos, dada a relativa interlocução entre a História e a Filosofia, minha trajetória de formação e os saberes da experiência. (Professor Denílson Santos de Azevedo)

Em termos. Dá a base mínima para lidar com os clássicos da área. Para uma boa atuação haveria necessidade de um investimento próprio, o que não foi feito, já que a docência em Filosofia foi periférica à minha atuação em Sociologia. (Professora Maria das G. M. Ribeiro).

Assume-se aqui, que a formação acadêmica em níveis de graduação e de pós-graduação, por si só, não garante a viabilidade para atuação nessas disciplinas. A graduação e a pósgraduação oportunizam cursar disciplinas de Filosofia da Educação, propiciando o básico. Também, a pós-graduação, seja em Educação, em Filosofia da Educação e em História e Filosofia da Educação, não é garantia de investimento na área, principalmente se o objeto de 
estudo não for Filosofia da Educação. É necessário que o professor envista em estudos e pesquisa no sentido de continuar seu processo formativo, cujo final é a própria morte.

Eis o que pensam os professores das disciplinas Filosofia da Educação:

São fundamentais, pois dilatam a compreensão do processo educacional. (Professor José Fagundes).

Penso que é fundamental na formação do professor, pois por meio dela (quando bem desenvolvida, articulada ao corpus teórico da filosofia e da epistemologia e da práxis) pode contribuir para uma reflexão que transite do imediato para o mediato; das impressões do cotidiano para uma elaboração crítica do conhecimento da realidade; de uma apreensão fragmentada para um conhecimento elaborado da realidade histórica. (Professora Olinda Maria Noronha).

Parece óbvio que incorporem-se na área dos fundamentos da educação, entretanto, a tendência de que estejam concentradas no início dos cursos empobrece sua potencialidade. Resposta não específica para a UFV. (Professor Willer A. Barbosa)

Penso que a formação em Filosofia da Educação é imprescindível, mas que a disciplina do modo como normalmente é oferecida, carece de maior densidade teórica. (Professora Rosimar de Fátima Oliveira).

De muita relevância para a formação docente. (Professor Dileno D. L. de Souza).

Penso que são importantes para a formação teórica e a ação pedagógica do futuro profissional. (Professor Denílson Santos de Azevedo).

A menos que se reduza a Pedagogia enquanto abordagem científica do fenômeno educacional a um tecnicismo absoluto, o domínio da reflexão filosófica sobre os problemas humanos, sociais, políticos e históricos que o ato de ensinar envolve, será imprescindível. (Professor José Carlos Costa).

Fundamentais. Deve haver uma base geral de Filosofia (1 disciplina) antes da Filosofia da Educação. (Professora Maria das Graças M. Ribeiro).

Fazem parte das disciplinas muito importantes para a formação do docente, o seu exercício de raciocínio lógico e análise das situações. (Professora Eneida Gondim).

Além de trabalhar na fundamentação teórica, trata-se de um exercício permanente de ir às raízes de todas as questões, além de oportunizar uma análise (racional) sobre a vida (de um modo geral). (Professor José Henrique de Oliveira)

Dos três professores, cuja área de atuação no Curso de Pedagogia era a da Filosofia da Educação, dois pensam-na como fundamental no processo de formação, por dilatar a compreensão do processo educacional; por contribuir para: uma reflexão, uma elaboração crítica do conhecimento, um conhecimento elaborado da realidade histórica, superando as impressões cotidianas e a apreensão fragmentada da realidade. O terceiro se posiciona contra a alocação das disciplinas no início do curso, por empobrecer sua potencialidade. Ressalte-se ser estranho que a posição da disciplina na grade curricular, nos primeiros períodos, seja fator 
de seu empobrecimento. Todavia, nenhum deles pensa a Filosofia da Educação como interrogação, como construção de sentidos do fazer educativo.

Os outros sete professores, cuja atuação se efetiva em Administração Escolar, História da Educação, Filosofia da Ciência, Sociologia da Educação e Psicologia da Educação, atuaram em colaboração, ministrando disciplinas de Filosofia da Educação, em face da carência de professores e, ou em razão de treinamento destes. Entrevistados, manifestaram-se sobre as disciplinas, ressaltando sua importância, relevância e imprescindibilidade no processo de formação de professores. Dois desses posicionamentos merecem destaque: o primeiro, por caracterizar a disciplina como carente de maior densidade teórica, e, o segundo, por apontar a necessidade de uma disciplina que forneça uma base geral de Filosofia, antes das disciplinas de Filosofia da Educação. É interessante o fato de que tais posicionamentos, que deveriam ter sido explicitados na época das reformulações do curso, não o foram. A disciplina se apresenta como um feudo do professor e, mesmo em situações em que ela é submetida à aprovação do coletivo, nenhuma manifestação com relação a ela se dá. Assim, o professor reina absoluto em sua disciplina e, pior, sem prestar contas do seu fazer.

Inquiridos sobre que papéis atribuiriam às disciplinas de Filosofia da Educação, assim se posicionaram:

Além de trabalhar na fundamentação teórica, trata-se de um exercício permanente de ir às raízes de todas as questões, além de oportunizar uma análise (racional) sobre a vida (de um modo geral). (Professor José Henrique de Oliveira).

Elas conferem uma visão crítica e de totalidade à educação, sem a qual esta não pode ser entendida adequadamente. A compreensão de educação não se esgota em suas variáveis internas; demanda uma visão que contemple suas articulações com outros segmentos da sociedade. E a filosofia contribui para isso. (Professor José Fagundes).

O papel da filosofia da educação no curso de pedagogia [...] fornecer categorias e conceitos filosóficos que subsidiem uma compreensão e explicação mais profunda da práxis educativa. (Professora Olinda Maria Noronha).

Gerar capacidade crítica; sensibilizar para perspectivas mais amplas de atuação dos educadores; criar o gosto pela leitura, pelo estudo e pelo diálogo; enfim, refletir sobre a tradição e sobre as práticas educativas. (Professor Willer A. Barbosa).

O papel de proporcionar formação adequada que permita a compreensão e a reflexão sobre os processos educativos. (Professora Rosimar de Fátima Oliveira).

Muito importantes. (Professor Dileno D. L. de Souza).

Papel de auxiliar na formação teórica e reflexiva do ideal e da prática pedagógica. (Professor Denílson Santos de Azevedo).

Proporcionar aos educadores o domínio conceitual rigoroso para se armarem de um arsenal analítico que os possibilite atuar no espaço educativo de forma lúcida, consciente e transformadora. (Professor José Carlos Costa). 
São fundamentais para a formação do educador. Não há como se pensar a educação sem um componente filosófico; por outro lado, a Sociologia, indispensável ao educador, também exige algum conhecimento de filosofia. (Professora Maria das Graças Marcelo Ribeiro).

Assim, as disciplinas são representadas e pensadas com função de fundamentação teórica para: conferir uma visão crítica e de totalidade à educação; fornecer categorias e conceitos filosóficos para compreensão e explicação da práxis educativa; formar adequadamente para compreensão e reflexão dos processos educativos; e proporcionar aos educadores domínio conceitual rigoroso. No geral, todas as atribuições conferidas à Filosofia da Educação privilegiam a dimensão teórica e a internalização de teorias, categorias e conceitos. Não é que a dimensão teórica não seja importante, ela o é, mas não se tomada dogmaticamente e, ou, para enquadrar a realidade. Ela é importante, quando assumida para potencializar interrogações.

Também, as atribuições de conferir e gerar uma visão crítica não são explicitadas em sua concretização. Não se podem conferir e nem gerar nos educandos a visão crítica. Pode-se provocar neles o desejo de a construírem.

Questionados como agiam em relação aos programas analíticos das disciplinas, quando nelas atuaram, e qual sua contribuição para a identidade delas, assim se posicionaram:

Revisamos e atualizamos por várias vezes os programas analíticos existentes. Acrescentamos textos de outros autores visando avançar nos conteúdos ministrados. (Professor José Henrique de Oliveira)

Apenas substitui a professora titular por um semestre. (Professora Eneida Pereira Gondim).

Não foram alterados. Não ofereci contribuições significativas por ter trabalhado a disciplina por apenas dois períodos. (Professora Maria das Graças Marcelo Ribeiro)

Ignorava o programa vigente e estabelecia o meu próprio. (Professor José Carlos Costa).

Não. Dividi apenas uma disciplina num semestre (1996). (Professor Denílson Santos de Azevedo).

Contribuir com uma formação ampla no processo de formação. (Professor Dileno D. L. de Souza).

Quando assumi a disciplina Filosofia da Educação alterei o programa analítico no item que se refere à bibliografia. Os conteúdos, em função do seu caráter genérico e superficial, foram mantidos. Quanto à minha contribuição para a construção da identidade da disciplina, foi a de adequá-la ao campo da educação, introduzindo literatura que aborda a contribuição da Filosofia para a educação. (Professora Rosimar de Fátima Oliveira)

Na UFV foram assumidos, tendo sido alterados no contexto da reformulação curricular de 2000. Uma vez que há frágil configuração interdisciplinar os 
processos identitários são dinâmicos e conflitivos. (Professor Willer Araújo Barbosa)

Quando assumi a disciplina procurei alterar os programas com relação aos conteúdos ministrados e a bibliografia utilizada para atender aos aspectos mencionados nas questões (o que penso da disciplina e que papel lhe atribuo), procurando manter parte da ementa inalterada. As alterações eram de ordem metodológica e epistemológica. A partir desta postura penso que este enfoque contribuiu para a formação dos pedagogos naquele momento. É bom ressaltar que este esforço não era individual, mas de um grupo de professores que trabalhavam em conjunto para que esta disciplina tivesse esta abordagem. (Professora Olinda Maria Noronha).

No início, desenvolvi os programas vigentes. No decorrer do tempo foram acrescidas contribuições, mormente com a realização do Doutorado na área. (Professor José Fagundes).

Analisando as respostas, em relação ao fato concreto das alterações dos programas analíticos das disciplinas de Filosofia da Educação, que ocorreram nos anos de 1979, 1989, 1999 e 2007, para vigência nos Catálogos de Graduação de 1980, 1990, 2000 e 2008, evidencia-se que três professores assumiram os programas analíticos vigentes no curso de Pedagogia da UFV, sendo que eram professores de outras áreas de atuação, e, em razão da carência de docentes, assumiram as disciplinas; um ignorava os programas analíticos vigentes e elaborava o seu próprio programa; um se manifestou dizendo que contribuiu com o processo de formação, mas não se manifestou em relação aos programas analíticos e à identidade da disciplina; dois assumiram que alteraram os programas analíticos das disciplinas que ministravam, com revisão e atualização, inclusive da bibliografia, mas isso não se procede, pois no período em que atuaram não havia registro de nenhuma alteração; um desenvolveu os programas analíticos vigentes até 1999, quando da reformulação curricular do Curso de Pedagogia, momento em que construiu os programas analíticos das disciplinas de Filosofia da Educação, que passaram a vigir em 2000; dois assumiram que procederam a alterações metodológicas e epistemológicas nos programas analíticos.

Confrontados com os dados vigentes nos Catálogos de Graduação da UFV, houve, sim, contribuição da Professora Olinda Maria Noronha e de um grupo de professores, entre eles Lucio Kreutz, que em 1979 construiu outra identidade para as disciplinas, em substituição à elaborada pelo Professor Guy Capdeville, por ocasião, do início do Curso de Pedagogia.

Também, em 1989, houve alteração dos programas analíticos pelo Professor José Fagundese, e provavelmente, pelo Professor Lucio Kreutz. É interessante notar que o Professor Fagundes justifica que, com o tempo, foram acrescidas contribuições, em função do seu doutoramento, em 1985, em Filosofia e História da Educação. Talvez isso explique o fato 
de que, só em 1989, ele tenha formalizado a alteração dos programas analíticos, para vigirem em 1990, pouco tempo antes de sua aposentadoria, que ocorreu em 09 de abril de 1991.

Pode-se, portanto, dizer que a identidade das disciplinas Filosofia da Educação, do Curso de Pedagogia da UFV, foi forjada pelos Professores Guy Capdeville, Olinda Maria Noronha, Lucio Kreutz, José Fagundes e Willer Araújo Barbosa. 


\title{
6 A FILOSOFIA DA EDUCAÇÃO: ELUCIDAÇÃO DO FENÔMENO EDUCATIVO E POSSIBILIDADE DE AUTONOMIA
}

\begin{abstract}
Em primeiro lugar, essa passagem da educação (como práxis e como tradição) à pedagogia (como teoria e como construção de modelos autônomos e inovadores em relação à tradição). Depois, a construção de um grande ideal de formação humana com a paidéia: repita-se, o homem só é tal por meio do comércio íntimo com a cultura, que deve estruturá-lo como sujeito e torná-lo indivíduo pessoa. E ainda: a idéia dos studia humanitatis ligados à centralidade da literatura e da história, dos saberes do homem e pelo homem, que devem ser também o eixo cultural da escola e dos próprios programas de estudo. Como também a divisão da formação e da escola em dois âmbitos: desinteressada, cultural, de caráter teórico e contemplativo, por um lado; técnica, pragmática, de caráter aplicativo, por outro, realizada nas oficinas e destinada ao aprendizado. São alguns dos princípios que virão a estruturar durante dois mil a 2.500 anos os modelos e as agências de formação próprios da tradição ocidental e que terão uma dimensão de "longa duração".
\end{abstract}

Cambi

Pensar e falar sobre a educação pressupõe a contribuição dos gregos: não no sentido de modelo ou paradigma a ser reproduzido, mas como propõe Castoriadis, na condição de gérmen (CASTORIADIS, 1987b, p. 271). Berço da cultura ocidental, a influência grega se faz sentir em diversos domínios humanos, mas interessa, sobremaneira, à problemática educativa. A epígrafe explicita alguns princípios formulados pelos gregos que, ainda hoje, estruturam e se fazem liame da educação a essa herança.

Destaca-se, entre eles, “[...] a passagem da educação (como práxis e como tradição) à pedagogia (como teoria e como construção de modelos autônomos e inovadores em relação à tradição)", que se localiza, temporalmente, na época dos sofistas e de Sócrates. Para Cambi (1999), nasce a pedagogia como saber autônomo, sistemático, rigoroso; nasce o pensamento da educação como episteme, e não mais como éthos e como práxis apenas.” (p. 87). É a paidéia dos filósofos. Em Sócrates, “[...] como problematização e como pesquisa, que visa a um indivíduo em constante amadurecimento de si próprio, acolhendo em seu interior a voz do mestre e fazendo-se mestre de si mesmo" (p.88). Em Platão, há dois tipos de paidéia: a socrática e a política. A primeira refere-se à formação da alma individual, que, sob o controle da razão, objetivaria a pura contemplação das idéias, mas, ela não pode ser pensada descolada da paidéia política, na qual o modelo de formação é específico para cada classe social: a dos produtores, a dos guardiões-guerreiros e a dos governantes-filósofos. Esta paidéia “[...] permanecerá na cultura ocidental como um modelo-máximo [...]” (p. 91). Em Isócrates, vige 
a do logos. Em Aristóteles, "[...] a pedagogia é reconfirmada, seguindo Platão, como disciplina formadora da alma e como ação civil, ligada à cidade” (p. 92) e o processo de formação consiste na realização das virtudes dianoéticas (racionais).

Assim, é em Platão e na sua paidéia que se encontra a raiz de um dos principais problemas que perspassa a educação até a contemporaneidade: a supervalorização do conhecimento, isto é, sua primazia sobre todas as demais atividades humanas, a supremacia do conhecimento teórico sobre o prático. Na época moderna, essa sobrevalorização do conhecimento - científico - culmina na crença de que a ciência e a técnica tudo podem e tudo fazem, tanto no domínio das coisas, como no domínio dos homens. É nesse sentido que Valle (2003) diz que se pensa e se age como fosse "[...] possível um saber certo e infalível sobre a educação (e sobre a política), mas que esse saber é o único que deve guiar sua realização" (p. 11). Aqueles que assim o fazem, pensam a educação como campo do determinado, onde é possível um saber totalizante sobre o sujeito e sua formação, que o problema está no encontrar a técnica exata para se educar corretamente. O possível na educação torna-se, portanto, a adequação do humano à sociedade, a todo e qualquer custo. Castoriadis (1992) comenta com ironia:

Um psiquiatra comportamentalista (de fato, pavloviano), um "pedagogo" como o pai do presidente Schereber, os guardas de um campo de concentração nazista ou stalinista, os agentes do Minilove, e o próprio O'Brien (ORWELL, 1984), todos agem para mudar seres humanos - e, frequentemente, têm êxito (p. 152-153).

Nesse tipo de mudança, objetiva-se erradicar do humano um pensar e um querer próprios, para modelá-lo, adestrá-lo, segundo o que se pretende. Aqueles que a praticam, fazem da educação uma prática antecipada, ou seja, a priori, eles sabem como as coisas devem acontecer.

Mas a educação, como prática social, aconteceu, acontece e acontecerá. Sujeitos são educados e a história é testemunha de que essa educação não consistiu em modelagem, em formatação e adestramento. As questões se multiplicam, sem respostas: o que é educação? Qual seu sentido? Quais suas finalidades? Quie educação para que tipo de sociedade? Quem é o aluno? Pode-se, supostamente, saber o que fazer com ele? Será que se saberia algum dia claramente o que fazer e como fazer para educá-lo? Contudo, essas questões não se fazem presentes no cotidiano dos educadores, pois estes, em seu processo de formação, tanto sob a influência da paidéia platônica, como sob o cientismo da época moderna, crêem haver teorias que as respondem inteiramente; e, portanto, sobre elas não mais refletem, não se interrogam.

Para Valle (2003): 
[...] há muito a área da educação já não investe nas interrogações sobre o homem com quem trata e que é o centro de sua atividade, o que tem reflexos bastante claros sobre as formas correntes de se considerar o professor, o currículo, a história, as leis e seu caráter instituinte, as teorias e métodos educativos e, é claro, o aluno. Isso se deve, em grande parte, ao fato de que todas essas questões parecem já ter sido satisfatoriamente resolvidas pelas teorias científicas a que os especialistas fazem recurso; e de que os educadores, quanto a eles, simplesmente não acreditam ser sua tarefa colocar em questão esses fundamentos sobre os quais assentam-se sua formação e as "teorias" que lhes são regularmente servidas. (p. 13).

E o que é a educação, senão um encontro, uma relação entre sujeitos, intencionalizada por uma mudança, uma transformação. No encontro entre sujeitos, educador e educando; no processo de formação, nada se sabe sobre o que se pode esperar, nenhum controle se tem sobre o processo, nenhuma previsão do resultado desse encontro, pois a reação de cada um é algo não possível de presciência, pois não é uma relação entre coisas e sim, entre sujeitos - é o inesperado. Assim, educar requer certa disposição para lidar com o espanto, com o risco, com o enigma.

A educação é, portanto, o campo do indeterminado, o qual, em Castoriadis (1987b), é:

A não determinação do que existe não é simples "indeterminação" no sentido privativo e, em última análise, trivial. Ela é criação, a saber, emergência de determinações diferentes, de novas leis e de novos domínios que se submetem a elas. A "indeterminação" (se é que ela não significa apenas um "estado de nossa ignorância", ou uma condição "estatística") tem este sentido preciso: nenhum estado do ser pode ser tal que venha a tornar impossível a emergência de determinações diferentes das que já existem (p. 417).

Pensar e praticar a educação, como campo do indeterminado, implica fazê-lo sem os $a$ priori que fundamentam previamente como as coisas devem acontecer; sem nenhuma verdade que possa assegurar o controle absoluto da situação educativa, sem nenhuma possibilidade de previsão dos resultados. É assumir que a formação do sujeito é um risco.

A formação do sujeito é um risco, pois, no encontro entre educador e educando, têmse o encontro ou desencontro de duas liberdades. Para KANT (1996), a pedagogia ou doutrina da educação apresenta-se física - cuidados com a vida corporal - e prática ou moral construção (cultura) do homem, para que possa viver como um ser livre. E ele denomina a educação de prática, porque “[...] chama-se prático tudo o que se refere à liberdade.” (p. 36). Mas uma prática que deve ser raciocinada.

Em sua obra Sobre a Pedagogia, Kant (1996) diz: "Entre as descobertas humanas há duas dificílimas, e são: a arte de governar os homens e a arte de educá-los” (p. 21). Posteriormente, Freud (1937), em Análise terminável e interminável acrescentará a política e as dira atividades impossíveis. Mas Castoriadis (1992), afirmará que impossíveis são a pedagogia, a análise e a política. Ele substitui a arte de governar por política, pois governar os 
homens é possível, mas transformá-los sujeitos políticos, não o é. E por que são impossíveis tais atividades? Elas o são, não porque lidam com o ser humano, mas porque visam mudá-los, no sentido de estarem “[...] capacitados e livres para fazer coisas” (p. 162). É, pois, a liberdade o nó górdio das atividades práticas - política, análise e pedagogia.

Para Valle (2002):

Diante da liberdade, um conhecimento sobre o homem que se pretendesse puro, $a$ priori, independente da experiência é um paradoxo: ele só seria possível se houvesse uma essência a predeterminar a existência humana - e nesse caso o homem não seria mais livre; ou então, se a razão pudesse pretender o saber absoluto, divino, capaz de conhecer os seres livres - e nesse caso, não se teria mais um homem, senão um deus. Eis por que a educação não é uma ciência, mas uma arte, segundo a distinção que Kant oferece na Crítica da faculdade de julgar: porque o simples conhecimento do que deve ser feito e do efeito buscado não é suficiente para determinar sua ação (p. 267).

É a liberdade, que foge à determinidade, que impossibilita uma teoria completa e exaustiva do humano, que impede o controle e a previsão da técnica. É a liberdade, possibilidade do humano, que permite falar de transformação, de criação, de autonomia, enfim, de construção do mundo próprio, em outra perspectiva. É, ainda, a liberdade que dá à educação a dimensão de uma atividade, uma práxis, cuja tarefa é ininterrupta em sua conclusão e não se permite ser restringida por nenhuma verdade.

Isso não significa que se deva abjurar a atividade teórica. Pelo contrário, é necessário que nela se invista como possibilidade para tentar compreender o humano. Mas ela não pode ser assumida deterministicamente, pois o conhecimento, especialmente sobre o homem, é fragmentário, lacunar, provisório, incompleto e construído na própria atividade.

Se "[...] a prática tem uma ligação estreita com a 'teoria', assim como com o que a teoria diz que, sobretudo com o que a teoria cala, exclui de seu campo, torna não pensável para quem o aceita" (CASTORIADIS, 1987, p. 103), isto constitui condição sine que non para que não se abdique da teoria - “[...] um fazer, a tentativa sempre incerta de realizar o projeto de uma elucidação do mundo" (1982, p. 93). Isso tem validade também para a Filosofia e, em especial, pelo que esta se interessa, para a Filosofia da Educação, pois o professor e o analista:

[...] é constantemente presa da exigência de um "pensar" e de um "fazer" diante do desenrolar de um enigma interminável [...] que ele deve elucidar in concreto por meio de construções "teóricas", sucessivas, sempre fragmentárias, essencialmente incompletas, nunca rigorosamente "demonstráveis [... (CASTORIADIS, 1987a, p. 117).

A atividade de pensar a educação concerne, ou deveria concernir, a todos os que a praticam: o "[...] "eu penso que..." é importante, porque ela abre a discussão e a crítica" (CASTORIADIS, 1987b, p. 107). 


\section{Como alega o autor:}

[...] pensar é precisamente abalar a instituição perceptiva na qual todo lugar tem o seu lugar e todo momento tem a sua hora - assim como é abalar a instituição dada do mundo e da sociedade, as significações imaginárias sociais que essa instituição encerra. [...] A instituição perceptiva é instauração de uma vez para sempre do que é o fundo e do que, jamais, pode ser figura, como do modo, do ser-assim de sua relação, de sua distinção e solidariedade.

Passa-se mais ou menos assim, quando se trata da instituição do pensamento como já feito, aceito, assimilado - de fato, inerte ou morto. Mas o pensamento original estabelece/cria figuras outras, faz ser como figura o que até então não podia sê-lo e isso não pode acontecer sem um dilaceramento do fundo existente, do horizonte dado e da sua recriação. (CASTORIADIS, 1987a, p. 27-28).

Mas esta não é a realidade da educação brasileira, em qual, no geral, assume-se o pensamento já feito e não o pensamento criação, em que o conflito da vida do pensamento é quase zero: "[...] entre o investimento da coisa já pensada (e de si como "já tendo pensado tal coisa certa") e o investimento - eminentemente arriscado, pois essencialmente incerto e vulnerável - de si como origem podendo criar pensamentos novos (e do que há sempre a pensar além do já pensado)" (CASTORIADIS, 1987a, p. 129), prevalece o primeiro.

Ainda na educação, tem-se atribuído à escola não mais a formação que faria da criança um ser humano, mas a consecução simultânea de "dois objetivos contraditórios, [...]: fabricar, em série, indivíduos predestinados a ocupar tal ou tal lugar no aparelho de produção, através de uma seleção mecânica e precoce; e “dar livre curso à expressão da criança."” (CASTORIADIS, 1987b, p. 99). Tem-se, como conseqüência do primeiro objetivo, a transformação da escola em instrumento para obtenção de diploma e seu dês-investimento como espaço de formação - para os professores ela se tornou um penoso ganha pão; para os discentes, uma imposição tediosa e para a sociedade, a fabricação de indivíduos heterônomos -, do segundo objetivo, uma crise dos programas, uma crise daquilo em vista do que esses programas são definidos e uma crise da relação educativa.

A resposta a essas crises da educação, que são reflexos da crise da sociedade, crise das significações imaginárias sociais, só pode ser a prática da construção política, prática que institui ou encarna os sentidos, inclusive o da educação, os quais concernem ao coletivo da sociedade, mas, em especial, ao coletivo educador.

Contudo, a prática de construção política, que se faz pelo imaginário radical, pelo imaginário social instituinte e pela capacidade criadora da coletividade anônima, deve enfrentar a questão das instituições existentes na sociedade, pois tanto na sociedade, quanto nas instituições e nos indivíduos, é construído um dispositivo para preservar, continuar e reproduzir esse dispositivo, que são as instituições existentes. Isso se efetiva pela fabricação social dos indivíduos, sua socialização. O grande problema da construção política é a não 
aceitação da mortalidade de si, das instituições e de suas obras. Para Castoriadis (1992), "O medo da morte é a pedra angular das instituições" (p. 164). É nesse sentido que o autor define o objetivo da pedagogia como "[...] a instauração de um outro tipo de relação entre o sujeito reflexivo - sujeito de pensamento e de vontade - e o seu inconsciente, isto é, a sua imaginação radical; e em segundo lugar, a liberação da sua capacidade de fazer e de formar um projeto aberto para a sua vida e trabalhar nele" (p. 159). Constituiria, também, objetivo da política outro tipo de relação entre sociedade instituída e instituinte; entre as leis existentes e a atividade reflexiva e deliberativa do corpo político da sociedade, seus cidadãos e a construção/realização de projetos coletivos por eles. Mas esses objetivos, tanto da pedagogia como da política, pressupõem um novo tipo de indivíduo - o sujeito reflexivo e um tipo de espaço - o espaço democrático.

Inexistentes na sociedade brasileira - o sujeito reflexivo e o espaço democrático -, pensa-se o que, no fazer educativo, poderia contribuir, embora não se tenha garantia de que o faça, para a construção destes. Uma das respostas que se apresenta seria a contribuição da Filosofia da Educação na formação dos educadores. Mas que Filosofia da Educação?

Pensa-se que a Filosofia da Educação, que, historicamente, recebeu as designações de Pedagogia: “[...] la em cuanto filosofia de la educación, formula los fines de la educación, las metas que deben alcanzarse [... (ABBAGNANO; VISALBERGHI, 1964, p. 15); Teoria de la educación: "Como las ciencias - que disfrutan de muy buen nombre gracias a sus incuestionables éxitos - utilizan la palabra "teoría" [...] muchos tratadistas de la pedagogia han preferido usar la expresión "Teoría de la educación" para sus trabajos [...]" (FULLAT, 1979, p. 69); e as conotações de "história das respostas"; "síntese das contribuições das ciências que investem a educação"; "gestora da malha de interdisciplinaridade na construção do sentido da educação"; "reflexão epistemológica"; "definidora dos fins da educação"; "fundamento da educação" etc., com pouco ou nada poderá contribuir para a transformação do indivíduo em sujeito humano, isto é, em subjetividade reflexiva e deliberante e a construção da democracia.

Segundo as contribuições de Castoriadis e Valle, a Filosofia da Educação poderia contribuir para a consecução de construção do sujeito reflexivo e do espaço democrático na medida em que se interrogasse, incessantemente, sobre os sentidos da educação, sobre os sujeitos nela envolvidos - educador e educando -, sobre a prática educativa e os condicionantes sociais, econômicos, políticos, as significações imaginárias sociais da sociedade brasileira, sobre a especialização/fragmentação das ciências humanas, sobre a legitimidade das "ciências da educação", sobre o papel da técnica na prática educativa etc. 
Para a concretização de tal perspectiva da Filosofia da Educação, julga-se ser necessário: a instalação de uma crise das verdades e das certezas dos educadores e dos educandos; a manifestação do desejo de autonomia/cidadania/democracia; o estudo/conhecimento da história da Filosofia da Educação pelo educador; a construção, pelo educador, de um projeto para os seus educandos; a prestação de contas públicas pelo educador, do que pensa, diz e faz da sua prática educativa e a interrogação ilimitada de si, do outro e da sociedade - das significações imaginárias sociais -, pelo educador e pelos educandos.

A instalação de uma crise das verdades e das certezas dos educando precede a possibilidade de construção da atitude de que as certezas, os hábitos, as crenças e os valores, que constituem o mundo próprio, podem e devem ser continuamente colocados em questão. A crise consiste numa ruptura repentina do equilíbrio, até então existente, em relação às significações imaginárias sociais internalizadas no processo de socialização.

A questão que se coloca, então, é: pode e deve o professor/educador intervir junto ao educando, para que este coloque em xeque suas certezas, hábitos, crenças e valores? Pensa-se que sim, principalmente em duas áreas, a da Filosofia e da Filosofia da Educação.

Como a educação é um processo simultâneo de socialização e de individuação, que, por força do que é específico do mundo próprio da sociedade - autoconservação, autoperpetuação e autocentrismo - tende à socialização, na postura que se propõe, a educação visaria inibir, minimamente, a imaginação radical do educando e desenvolver, ao máximo, sua reflexividade. Isso consistiria na interiorização das instituições e na interrogação sobre a validade destas. Trabalhar-se-ia no sentido de educar para a individuação, para a autotransformação do educando, no sentido de construção de sua autonomia, como investimento psíquico à liberdade e à intenção de verdade. Para isso, é preciso querer, pois “[...] para fazer é preciso querer" (CASTORIADIS, 2002, p. 63) e aceitar “[...] a morte daquele que era para tornar-se outra pessoa; [...]" (CASTORIADIS, 1992, p. 163).

Seria uma política da autonomia, que, segundo Castoriadis (1992):

A autonomia não é um fim em si; ela é também isso, todavia queremos a autonomia
também e, sobretudo para estarmos capacitados e livres para fazer coisas. [...] não é
o psicanalista, o pedagogo, a consciência da sociedade, no entanto constitui uma
dimensão essencial da sua reflexividade. Como tal, deve agir sobre os seres
humanos colocando-os como autônomos, a fim de ajudá-los a atingir sua própria
autonomia, sem esquecer nunca que a fonte última da criatividade histórica é o
imaginário radical da coletividade anônima (p. 162).

Entretanto, uma política de autonomia significa remeter o indivíduo ao socialhistórico. Não se pode ser livre sozinho, nem em qualquer sociedade; não se pode investir, 
psiquicamente, na liberdade, se ela não for uma significação imaginária social; não se pode ser autônomo, se não se der a própria lei, seja participando de sua formação e de seu funcionamento, seja aceitando e validando o que está instituído, após submetê-lo a crivo da análise. Significa, também, pensar o indivíduo, enquanto psique:

[...] outra relação é estabelecida entre a instância reflexiva e as outras instâncias
psíquicas, como também entre seu presente e a história graças à qual ele se fez tal
qual ele é, e, pôde escapar à servidão da repetição, refletir sobre ele mesmo, sobre as
razões de seus pensamentos e sobre os motivos de seus atos, guiado pela intenção do
certo e elucidação de seu desejo. Que essa autonomia possa efetivamente alterar o
comportamento do indivíduo (como sabemos que pode fazê-lo) quer dizer que este
deixou de ser puro produto de sua psique, de sua história, e da instituição que o
formou. Em outras palavras, a formação de uma instância reflexiva e deliberante, da
verdadeira subjetividade, libera a imaginação radica do ser humano singular, como
fonte de criação e alteração. E a formação dessa instância faz com que ele atinja uma
liberdade efetiva, que pressupõe certamente a indeterminação do mundo psíquico e
sua permeabilidade ao sentido. Contudo, essa mesma formação acarreta também que
o sentido simplesmente dado deixou de ser causa (o que também é sempre o caso no
mundo social-histórico) e que há escolha do sentido não ditado previamente
(CASTORIADIS, 1992, p. 140-141).

Admitir que o indivíduo é psique não faz do educador um analista, mas leva-o a aceitá-lo e compreendê-lo como complexo, enigmático e responsável pela sua autotransformação.

Todavia, a responsabilidade, o compromisso e a prestação de contas do fazer do educador, nessa perspectiva, assumem uma dimensão muito maior. Ainda que o educando seja o agente do seu próprio processo educativo, a intervenção do educador, no sentido de ajudá-lo a se autointerrogar e a interrogar a sociedade, deve acarretar um compromisso de apoio ao processo de construção de um sujeito não adequado à sociedade existente sociedade heterônoma -, e a construção da atitude de que o que se tem, como certo e verdadeiro, pode e deve ser constantemente interrogado. Esse processo pode e deve ser contínuo, ininterrupto, no sentido de opor-se à acomodação, ao conformismo e à sacralização das verdades, das certezas, dos hábitos e dos conhecimentos.

A crise pode e deve gerar no educando a manifestação do desejo/querer a autonomia. Isso pressupõe a existência das significações - autonomia, liberdade e democracia, que são herdadas da cultura greco-ocidental, mas precisam ser investidas tanto pelo educador, como pelo educando. A autonomia individual e social como projeto é, em Castoriadis (1992), política. Pensar e querer autonomia significa, também, pensar e querer cidadania e democracia. Tanto o querer quanto as representações são formados, constantemente pelo conjunto do mundo instituído, o que não quer dizer que foram formados uma vez para sempre. Eles podem ser e são, pelo imaginário, reinterpretados e resignificados, 
a partir do que se está fazendo e pensando na sociedade. Mas a manifestação do desejo de autonomia pressupõe também a compreensão do educador e do educando, como um para sivivente, psíquico, indivíduo social e sociedade..

O para si significa o mundo próprio do vivente, que, em sua autofinalidade, consiste na apresentação, representação e relacionamento do que é representado. A apresentação é a criação da informação pelo vivente, que o faz à sua maneira, isto é, colocação em figura e em relação a. Para Castoriadis (1992), as dimensões do figurar e ligar devem apresentar certa regularidade e devem ser valoradas:

O que é apresentado deve ser valorado de uma ou de outra maneira, positiva ou negativamente; a ele é destinado um valor (bom ou mau, alimento ou veneno, etc.); torna-se portanto suporte (ou correlato) de um afeto positivo ou negativo (no mínimo neutro). E essa avaliação - ou esse afeto - guia daí por diante a intenção ("o desejo"), conduzindo, eventualmente, a uma ação correspondente (de aproximação ou de esquivamento). [...] Em toda parte onde há para si haverá representação ou figura, haverá afeto, intenção; nos termos antigos, lógico-poiético, tímico, orético. Isso vale tanto para a bactéria como para um indivíduo ou uma sociedade (p. 210211).

Ainda para o filósofo-psicanalista, o psíquico é um para si que se diferencia do vivente, porque sua especificidade não é a sexualidade, mas a sua distorção. Esta é transversal ou horizontal, vale para todas as instâncias psíquicas. e caracteriza-se por disfuncionalização dos processos psíquicos em relação ao substrato biológico, dominação do prazer representativo sobre o prazer de órgão, autonomização da imaginação e autonomização do afeto no psiquismo humano. É especificidade, ainda, do psiquismo humano, na sua dimensão vertical, a estratificação e a multiplicidade de instâncias.

Assim, a psique - imaginação radical - é gênese de representações; emergência de representações ou fluxo representativo, acompanhadas de um afeto (positivo ou negativo) e inseridas num processo intencional. Pensar a atividade do indivíduo implica compreendê-la como pulsão, no geral inconsciente, que a dirige e incita; que se manifesta em representação, afeto e intenção:

O papel essencial da imaginação, sem que esta seja reconhecida ou mesma citada, aparece de fato em Freud, através da importância central da fantasia na psique e a relativa independência e autonomia do fantasiar. $\mathrm{O}$ fantasiar é descoberto como componente ineliminável da vida psíquica profunda. Mas como explicar sua relação com os outros componentes dessa vida, a origem do seu conteúdo com os outros componentes dessa vida, a origem do seu conteúdo, a fonte de sua força?

A pulsão (Trieb) só pode manifestar-se na psique por intermédio de uma representação; a psique submete a pulsão à obrigação da delegação por representação (Vorstel-lungsreprasentanz desTriebes); também, indubitavelmente, da "delegação por afeto", mas isso é um outro problema. Mas qual é a origem desta representação e qual pode ser seu conteúdo e, sobretudo: porque é este conteúdo? (1982, p. 324). 
Mas algumas questões se apresentam: como se constitui uma representação, qual seu conteúdo e sua forma organizativa? Como ela se relaciona com o real? A tais interrogações, responde Castoriadis (1982):

\begin{abstract}
A psique é certamente "receptividade de impressões", capacidade de ser-afetada por; mas ela é também (e sobretudo - sem o que esta receptividade de impressões nada daria) emergência da representação, enquanto modo de ser irredutível e único e organização de alguma coisa em e por sua figuração, sua "colocação em imagem". A psiquê é um formante que só existe em e por aquilo que ele forma e como aquilo que ele forma; ela é Bildung e Einbildung - formação e imaginação - ela é imaginação radical que faz surgir já uma "primeira" representação a partir de um nada de representação, isto é, a partir de nada.

Não pode haver vida psíquica se a psique não é capacidade originária de fazer surgir representações, e, "no início" uma "primeira" representação que, de certa maneira, deve contar em si a possibilidade de organização de toda representação - que seja um formado-formante, uma figura que será germe de esquemas de figuração -, portanto, sob a forma mais embrionária que quisermos, os elementos organizadores do mundo psíquico que se desenvolverá a seguir, certamente com adjunções decisivas vindas de fora, mas necessariamente recebidas e elaboradas de acordo com as exigências estabelecidas pela representação originária (p. 325-326).
\end{abstract}

A vida psíquica tem, no imaginário, o poder de "[...] preencher, fechar, cobrir o que é necessariamente abertura, clivagem, insuficiência do sujeito" (p. 331). Qual o porquê dessa necessidade do sujeito? Ela é consubstancial ao sujeito - é uma falta, falta de seu objeto -, e constitui o desejo. O sujeito é, portanto, desejo encarnado. E o que torna para a psique um objeto como falta, como desejo; sob que condições um objeto pode ser, para a psique, falta, perda, diferença?

$\mathrm{Na}$ realidade psíquica, a única real representação para a psique é: "tudo como si mesmo", onde sujeito e objeto do desejo coincidem, onde o sujeito é a cena da fantasia e realiza, sempre, todos os desejos. Nessa realidade, há fechamento, domínio, simultaneidade e congruência absoluta entre a intenção, a representação e o afeto.

Entretanto, com a ruptura do núcleo monádico, representada pelo arrombamento operado pelo objeto separado do sujeito, pelo outro e pelo próprio corpo, a psique está “" [...] para sempre excentrada em relação a ela mesma, orientada por aquilo que ela não é mais e não pode mais ser. A psique é seu próprio objeto perdido" (p. 339). Este é o primeiro trabalho imposto à psique pela sua inclusão no social-histórico.

É a instituição social do indivíduo, sua fabricação social. É a transformação da psique - mônada psíquica - em indivíduo social se faz pela educação. É realizada por outros indivíduos, objetos, sociedade e instituições que, originariamente, não têm existência para a psique. É a formação do consciente. A socialização/fabricação social:

[..] leva ao individuo social, uma entidade falante, que tem uma identidade e um estado social, ajusta-se mais ou menos a certas regras, busca certos fins, aceita certos valores e age conforme motivações e modos de fazer suficientemente estáveis para 
que seu comportamento seja na maioria do tempo previsível, justo o necessário, para os outros indivíduos. O conjunto do processo tem por condição a capacidade de sublimação da psique, [...] (CASTORIADIS, 1992, p. 220).

Ainda segundo o filósofo:

A evolução ulterior, constatável, do sujeito é, a partir de um ponto de ruptura,
história de uma série de criações de representações, como diferenciadas e diferentes,
de um fluxo representativo/afetivo/intencional que só cessará com a morte do
sujeito, que se desenvolve à custa de perturbações sucessivas e de remanejamentos
em profundidade da organização psíquica, cujos depósitos estratificados e
intercomunicantes o sujeito "maduro" encarna - e que é essencialmente a história da
socialização da psique, ou seja, da criação pelo teukhein e o fazer dos outros, de um
indivíduo social (1982, p. 340).

A socialização efetiva-se pela ação de indivíduos sociais sobre a psique da criança, para que esta internalize as significações imaginárias sociais. É nesse processo que a instituição da sociedade pode limitar a imaginação radical da psique e fazer existir, para ela, a realidade. Ora, a inclusão da psiquê no mundo implica que o que não se presta à representação, a ela se anuncie e se imponha - uma certa realidade -, como diferente do sujeito. O princípio do prazer sofre a torção, iniciando o segundo trabalho imposto à psique: a repressão - evitação do desprazer - que remete ao inconsciente as criações da psique reprimidas.

Assim:

\begin{abstract}
A imposição da relação com o outro e com os outros (relação que é sempre e ao mesmo tempo, tanto "fonte de prazer" e "satisfatória", como "fonte de desprazer" e “perturbadora") é uma sucessão de rupturas infligidas à mônada psíquica através da qual é construído o indivíduo social, como dividido entre o pólo monádico, que tende sempre a fechar tudo e submeter tudo a curto-circuito, para trazê-lo ao "estado" monádico impossível, e, em sua ausência, a seus substitutos, satisfação alucinatória e "fantasmatização", - e a série de construções sucessivas mediante as quais a psique de cada vez, mais ou menos, consegue integrar (isto é, representou, investiu afetivamente e ligou por um tender para ou uma intenção) o que lhe foi imposto (CASTORIADIS, 1982, p. 344).
\end{abstract}

A psique socializada é o processo de instituição social do indivíduo, outro para si. Nesse processo, são indissociáveis "uma psicogênese ou idiogênese, e uma sociogênese ou koinogêse” (CASTORIADIS, 1982, p. 343). O indivíduo social só pode ser compreendido, simultaneamente, pelo estudo da origem e pelo desenvolvimento das funções psíquicas e da formação da sociedade que o fabrica, pois ele é mônada psíquica em sua resistência à socialização, é couraça tecida pelas significações imaginárias sociais. Isso o faz ser como coexistência de um mundo privado (kosmos idios) e de um mundo comum, público (kosmos koinos). O mundo verdadeiro, mundo comum ou público e o que ele comporta - objetos, sujeitos outros, instituição e o mundo - só se torna real para o socializando, quando ele é 
remetido “[...] à instituição da significação e à significação como instituída e não dependendo de nenhuma pessoa particular" (CASTORIADIS, 1982, p. 352).

A relação do mundo público com o privado é a instauração de uma intersecção não vazia - que se faz pela sublimação:

[...] processo mediante o qual a psiquê é forçada a substituir seus "objetos próprios" ou "privados" de investimento (inclusive sua própria imagem para ela mesma) por objetos que são e valem na e pela instituição social, e fazer para ela mesma, "causas", "meios" ou "suportes" de prazer. Isso implica evidentemente, de um lado, a psique como imaginação, a saber, como possibilidade de estabelecer isto por aquilo, no lugar daquilo (quid pro quo); por outro lado, o social-histórico como imaginário social, a saber, posição na e pela instituição, de formas e de significações que a psiquê como tal está na impossibilidade absoluta de fazer ser. O acesso à linguagem no sentido pleno do termo (como linguagem pública), e o acesso ao fazer como social são duas instâncias cardiais disso (CASTORIADIS, 1982, p. 356).

O outro para si - o sujeito humano - é ponto central na produção castoriadiana. Interroga-se sobre quem pode reivindicar o título de sujeito? Para o autor, o sujeito não pode ser reduzido ao raciocínio lógico e nem ao cálculo, pois “[...] a atividade calculante e raciocinante não é própria à consciência vígil; ela existe em toda a parte na esfera psíquica e, podemos acrescentar hoje, em toda parte onde há para si, certamente em toda parte onde há vivente" (CASTORIADIS, 1992, p. 222-223).

Assume o filósofo que, em nos diferentes modos em que se manifestou, o para si que é sujeito reflexivo é uma criação histórica. Mas, enquanto possibilidade e virtualidade de um modo específico, que é a subjetividade reflexiva e deliberante, necessária ao projeto de autonomia, essa criação só se fez emergir por duas vezes na história da humanidade - na Grécia, com a criação da Filosofia e da Política, e na Europa ocidental, com a Revolução Francesa.

Mas, por que o projeto de uma subjetividade reflexiva e deliberante é raro na história humana? Em geral, porque a sociedade, ao instituir-se, institui-se como heterônoma e fabrica seus indivíduos como heterônomos, para quem tem validade a lei suprema - não discutirás ou não interrogarás. Ora, o para si, sujeito humano, tem como atributos a reflexividade e a vontade, que ele definiu como:

[...] a possibilidade de que a própria atividade do "sujeito" torne-se "objeto", a explicitação de si como um objeto não-objetivo, ou como objeto simplesmente por posição e não por natureza [...].

Chamo de capacidade de atividade deliberada ou vontade a possibilidade de um ser humano integrar nas retransmissões que condicionam os seus atos os resultados de seu processo de reflexão (além do que resulta da simples lógica animal). Em outras palavras: a vontade ou atividade deliberada é a dimensão refletida do que nós somos enquanto seres imaginários, a saber criativos, ou ainda: a dimensão refletida e prática da nossa imaginação como fonte de criação. (CASTORIADIS, 1992, p. 224226). 
É assim apenas que o sujeito humano, ao encarnar esses dois atributos, torna-se uma subjetividade reflexiva e deliberante. Ao criar-se como subjetividade, o sujeito pode e se interrogar sobre si e sobre a sociedade em que está imerso, pode se assumir ainda que parcialmente como origem de sua própria história e constituir um projeto deliberado para si, no sentido de responsabilizar-se, ainda que dentro dos limites do social-histórico, pela construção de si próprio, isto é, ser co-autor de sua própria história. Interrogar-se sobre si, no sentido de romper o fechamento em nível de pensamento, é exercer-se como subjetividade, é praticar filosofia..

Para a instituição da subjetividade reflexiva e deliberante, Castoriadis (1992) apontou quatro pressupostos: a sublimação, a existência de um quantum de energia livre ou de importantes capacidades de mutação de energia, junto da instância consciente, a labilidade dos investimentos nesse campo e a capacidade de questionar os objetos até então investidos em função da reflexão.

Pensa-se que o professor de Filosofia da Educação, como sujeito desejante que investe na autonomia, na cidadania e na democracia, pode, em sua prática, ajudar ao educando a construir, para si uma outra lei suprema - "obedecerás às leis, mas as discutirás" interrogando-se pela sua validade, pela sua construção e pela sua institucionalização; a compreender a educação como processo de socialização e de individuação, dependente da ação deste para concretizar-se; a construir e reconstruir o sentido para aquela que será a sua futura prática; a compreender o humano como medida de si próprio, e não como objeto de ciências e técnicas; e a admitir que a mortalidade é inerente ao vivente e que morrer significa a transformação em outrem, seja a sua própria morte, seja a morte da instituição.

Ser professor de Filosofia da Educação implica o conhecimento da história da Filosofia da Educação e, ou, a atitude de seu permanente estudo, como requisito necessário para a sua prática. Ora, falar da história da filosofia da educação é falar de mais de 25 séculos de produção sobre essa prática social - a educação, e ser professor é o que ensina algo - uma ciência, uma arte, uma técnica e uma disciplina. Mas, pensa-se que, em Filosofia da Educação, o papel do professor não é apresentar ao educando as literaturas que foram produzidas ao longo da história. Primeiro, porque seria a própria negação da essência da Filosofia e da Filosofia da Educação. Segundo, porque o arrolar de autores e de seu pensamento sobre a educação permitirá, apenas, uma panorâmica aligeirada dos filósofos e de sua contribuição à educação - uma sinopse -, que em nada concorreria para a construção de uma atitude de interrogação, pelo contrário, a inibiria e reprimiria. Consistiria, no máximo, na internalização do apresentado. Terceiro, porque o tempo exíguo da disciplina no curso - 60 a 
120 horas-aula, em geral, não permitiria essa apresentação panorâmica, mesmo enquanto sinopse. Quarto, porque o professor de Filosofia da Educação, seja ele graduado em Filosofia e Pedagogia, apresenta carência no seu processo formativo: o primeiro, porque teria na sua formação, mesmo sendo licenciatura, como historicamente preconizava a legislação, apenas as disciplinas de Psicologia da Educação, Didática e Estrutura e Funcionamento do Ensino, e o segundo, porque, em geral "conhece" fragmentos da história da filosofia, pois a ênfase do seu processo formativo tem-se reduzido nas questões educacionais.

Considerando tudo isso, pensa-se que, para sair do círculo vicioso: processo formativo deficitário - professor - processo formativo deficitário, impõe-se a aquisição da atitude de permanente e incessante estudo por parte do professor, bem como a incorporação do resultado desse processo na atividade de tomar sua própria prática e inquirir sobre ela.

Nessa perspectiva, ser professor, em especial, de Filosofia da Educação, pressupõe $\boldsymbol{a}$ construção, para si e para os seus educandos de um projeto:

[...] elemento da práxis (e de toda atividade). É uma práxis determinada, considerada em suas ligações com o real, na definição concretizada de seus objetivos, na especificação de suas mediações. É a intenção de uma transformação do real, guiada por uma representação do sentido desta transformação, levando em consideração as condições reais e animando uma atividade. [...] O que é, a este respeito, o núcleo do projeto, é um sentido e uma orientação (em direção a) que não se deixa simplesmente fixar em "idéias claras e distintas" e que ultrapassa a própria representação do projeto tal como poderia ser fixada a qualquer momento (CASTORIADIS, 1982, p. 97).

O fazer do professor, como todo fazer humano, está diretamente ligado a um saber informação, ciência, técnica - e pode ser também fruto da imaginação radical como criação, isto é, o fazer humano de toda e qualquer atividade - manual, técnica ou teórica - pressupõe uma relação com o saber, e é uma atividade consciente. Em seu fazer, o humano constroi uma representação da atividade a ser desenvolvida. Mas, constroi um sentido para esse fazer, o qual é uma representação. Contudo, a representação do sentido do fazer humano - orientação, intenção -, não é passível de fixação uma vez por todas, em ideias claras e distintas. É necessário que o professor construa sentido para a educação, para o fazer, e para sua própria disciplina. Caso contrário, como responder aos educandos, quando inquirirem: por que a escola? Por que o professor? Por que essa disciplina? Por que esse conteúdo?

É o projeto que permite definir o que fazer, para que fazer e como fazer.

Pensa-se que a Pedagogia, como práxis, a organização e o sentido do fazer do professor devam ser tais, de modo a permitir e estimular a autonomia dos educandos, mesmo reconhecendo que a autonomia não existe, mas que é possibilidade, virtualidade. Na práxis, “[...] a autonomia do outro ou dos outros é, ao mesmo tempo, o fim e o meio; a práxis é 
aquilo que visa o desenvolvimento da autonomia como fim e utiliza para este fim a autonomia como meio" (CASTORIADIS, 1982, p. 94).

Mas, enfim, por que o projeto é importante e que projeto deve construir um professor de Filosofia da Educação para os seus educandos? Ora, à primeira questão, responde-se: "Se não se sabe aonde se quer ir, como e por que escolher um caminho de preferência a outro?" (CASTORIADIS, 1992, p. 82). A resposta à segunda questão é um projeto de autonomia, de emancipação. Um projeto de autotransformação dos educandos, uma transformação de maneira que eles possam adentrar nesse processo de interrogação de si, do outro e do socialhistórico. Mas esse projeto do professor precisa fazer sentido para os educandos, o que implica

"Convencê-los racionalmente" significa ajudá-los a atingir sua própria autonomia. Por que fazê-lo? Porque queremos a autonomia para todos - porque submetemos tudo, inclusive as instituições dos outros, à questão do direito" (CASTORIADIS, 1999, p. 60).

\section{A interrogação ilimitada de si e da sociedade - das significações imaginárias sociais} -, pelo educador e pelo educando só existirá se se construir a atitude de que podem e devem ser continuamente colocados em questão, as certezas, os hábitos, as crenças e os valores que constituem o mundo próprio. Isto implica julgamento e escolha. Mas os julgamentos e as escolhas que se fazem pertencem e dependem da sociedade em que se vive. Quando se trata das coisas - o que são, como são e porquê são - têm-se os juízos de fato e, sobre eles, não há o que escolher e deliberar. Contudo, quando se trata de avaliação sobre coisas, pessoas, ações, experiências, acontecimentos, sentimentos etc., o julgamento, a escolha e a deliberação "[...] sempre ocorrem no interior e por meio de uma instituição social-histórica já existente, ou, então, procedem de uma nova criação frente à qual os únicos critérios disponíveis são os inaugurados por essa mesma criação.” (CASTORIADIS, 1987b, p 289). Então, como construir a atitude de interrogação, se ela não é pertinente ao social histórico? Pensa-se que através das mediações da paidéia e do nomos. Todavia, a educação e a legislação, numa sociedade heterônoma, pouco ou nada contribuem para se criar essa atitude. É nesse sentido que se pensa a contribuição da Filosofia e da Filosofia da Educação, como interrogação ilimitada nos processos formativos: na criação da autorreflexividade ou da subjetividade reflexiva e deliberante.

Castoriadis (1999), ao citar Aristóteles, expressa:

A virtude é uma disposição adquirida (exis) deliberativa... Definida pelo logos e como a definiria o phronimos. A exis é uma disposição que não é "pura", nem "espontânea": ela é, e deve ser, adquirida (daí, o papel decisivo da paidéia e do nomos). Ela é proairétiké, em dois sentidos: no sentido de seu "objeto", 
transitivamente, ela concerne à escolha, ela é um habitus que leva a escolher bem. Mas ela é também proairétiké, deliberativa, porque é um habitus de deliberação (reflexivo e deliberativo!), ela não é simples habitus, automatismo mecânico, ela guarda a proairésis, a intenção e a escolha. Ela é definida pelo logos - contém, portanto, um elemento racional e discutível. (p. 63).

Ora, a atitude de questionamento e de interrogação não constitui necessariamente o indivíduo social, mas é marca, como já afirmado, de um tipo específico de subjetividade - a subjetividade reflexiva e deliberante; ela é pois uma virtude, na acepção aristotélica, a ser criada. Aí, reside a importância do projeto de autonomia, tanto para o professor como para o educando - porque, mais do que a preocupação de formar alguns sábios, de treinar os indivíduos para o mundo do trabalho, educar é necessário para que se adquira e exerça a cidadania, buscando conquistar a participação real nos negócios comuns - res publica - bem como a paixão por eles, uma vez que, enquanto membro da sociedade, as decisões referentes aos negócios comuns incidem sobre todos. Se, com ele, já é difícil a construção desse novo eidos - a autonomia humana - sem ele, a possibilidade é zero.

O último compromisso para uma Filosofia da Educação, que se propõe, é a prestação de contas pública, pelo educador, do que pensa, diz e faz da sua prática educativa.

Pensa-se que o educador deve fazê-la, porque sua atividade tem como "objeto" não uma coisa, mas o outro, uma vida humana em seu processo de formação. Ora, o fazer do educador, bem como o do médico, tem sobre o educando/paciente conseqüências. Mas, enquanto o médico responde pelo seu fazer perante o paciente, os pacientes, o Conselho Regional de Medicina e a própria justiça, o educador não o faz perante ninguém. O máximo que se tem é a divulgação informal, entre os educandos, do que pensam sobre o professor.

Entretanto, na realidade educacional brasileira não há nenhum mecanismo de prestação de contas pelo educador do seu fazer, nem aos educandos, nem à comunidade escolar, nem à sociedade. Há sim, como parte da responsabilidade do educador, o preenchimento de um excesso de relatórios, de um excesso de burocracias referentes à avaliação dos educandos, mas nem de longe lembra a prestação de contas do educador.

Ora, a educação pública é uma necessidade coletiva, um direito custeado com recursos públicos arrecadados da própria sociedade, na forma de impostos, que tem no poder público, encarnado no Estado, o seu depositário e administrador. Os educadores são, no caso da escola pública, servidores do "Estado", o que deveria significar servidores da população e são, também, custeados com o dinheiro da própria população. Em se tratando de prestação de contas, a Constituição brasileira, em seu artigo de n. .70 , refere-se apenas, a dinheiro, bens e valores públicos, enfim, apenas ao que concerne ao econômico. Ainda a Lei de Diretrizes e 
Bases da Educação Nacional (Lei n. ${ }^{\circ}$ 9.394/96 de 20 de dezembro de 1996), tanto no Artigo 13, que explicita as incumbências dos educadores, quanto no Título VI - Dos profissionais da Educação, não menciona nada a respeito da prestação de contas do fazer.

Questiona-se: por que prestação de contas públicas pelo educador? Justifica-se a prestação de contas do educador de sua prática - pensar, dizer e fazer - porque ele é servidor da população, que deve julgar e avaliar o seu fazer. Trata-se de um momento de interrogação e discussão sobre a sua prática, visando à coerência e validação, bem como a demonstração real de cidadania - discutir, conceber e deliberar sobre a educação, porque é o momento e o tempo de assumir os riscos do fazer, o risco da responsabilidade.

Eis o que podem fazer o educador e sua disciplina Filosofia da Educação. 


\section{CONSIDERAÇÕES FINAIS}

Eu penso que a verdadeira atitude humana é assumir: aceitar, tomar a si a indeterninidade, o risco, sabendo-se que não há nem proteção nem garantia. [...] No momento verdadeiramente decisivo, não há proteção nem garantia. Devemos assumir os riscos, e assumir os riscos quer dizer que nós somos responsáveis por nossas ações.

Castoriadis

A discussão sobre a possibilidade de contribuição da Filosofia da Educação na construção, pelos educandos, de sua autonomia, constituiu o cerne deste trabalho. Para tal, buscou-se na teoria de Castoriadis sobre a instituição imaginária da sociedade a compreensão de como a sociedade se autocria e cria seus indivíduos, nas dimensões imaginária e conjuntista-identitária. Destacou-se, sobretudo, a dimensão imaginária que, por meio do magma das significações imaginárias sociais, estrutura as representações do mundo internalizadas pelo psiquismo humano, no processo de fabricação social dos indivíduos - a socialização - designando as finalidades da ação e impondo o que se pode fazer ou não fazer, dizer ou não dizer.

O processo de socialização da psique, que permite a autoconservação, a autoperpetuação e o autocentrismo da sociedade, pela "fabricação" dos indivíduos sociais, encontra sempre resistência da psique, que se pode manifestar como imaginação radical. E é nessa última atividade que se vislumbra a possibilidade de auto-alteração do sujeito humano, de construção de uma subjetividade autônoma, cujos atributos são a reflexividade e a vontade.

Pensa-se que o sujeito humano pode se construir pela paidéia. Mas, numa sociedade heterônoma, tanto a paidéia como o nomos tendem, em geral, à perpetuação do que está instituído, o que impede a criação da atitude de interrogação de si e da sociedade.

É nesse sentido que se buscou discutir a tarefa da disciplina Filosofia da Educação na formação do pedagogo. Concebida como discurso crítico, como análise e como reflexão, tal disciplina poderia contribuir para que os educandos construíssem em si a atitude de interrogação. Assim, planeou-se compreender a instituição dessa disciplina na formação dos educadores no Brasil, analisando o monopólio legislativo do Estado na educação, a institucionalização da formação dos professores, com a criação da Faculdade de Educação, em 1931, e do Curso de Pedagogia, em 1939, por Atos do Estado e as tentativas de cientismo da Educação no Brasil, que se traduziu nas décadas de 1920 e 1930 no movimento da Escola 
Nova, que consistia da introdução nos currículos de disciplinas, princípios e práticas científicas e técnicas.

A disciplina constava dos cursos de Administradores Escolares e de Formação de Professores Primário e Secundário do Instituto Pedagógico de São Paulo, posteriormente Instituto de Educação, vinculado à Universidade de São Paulo, e do currículo da Escola de Professores do Instituto de Educação da Universidade do Distrito Federal. Todavia, a obrigatoriedade da disciplina Filosofia da Educação é instituída em 1939, com a criação da Faculdade Nacional de Filosofia da Universidade do Brasil, hoje Universidade Federal do Rio de Janeiro, por meio do Decreto ${ }^{\circ}$. 1.190, de 04 de abril de 1939, que também cria o Curso de Pedagogia, no qual ela é componente obrigatório da matriz curricular.

Mas simultaneamente à institucionalização da Filosofia da Educação na formação dos profissionais da educação nos Institutos de Educação de São Paulo (1931) e do Rio de Janeiro (1932) e no curso de Pedagogia (1939), intensificava-se, no Brasil, o processo cientificista da educação, objetivando tornar a Pedagogia e o campo educacional, como um todo, mais científico, isto é, racionalizar a organização, o acompanhamento e o controle do processo educativo, para a concretização do resultado planejado. Como consequência do cientismo na educação, tem-se a denegação da dimensão política desta prática social.

Destacou-se nesse processo a liderança do Movimento dos Pioneiros da Educação, com ações e pensamentos de Anísio Teixeira, Fernando Azevedo e Lourenço Filho, entre outros.

Assim, a Filosofia da Educação, antes considerada disciplina "nobre", viu-se expropriada no seu discurso sobre a educação. Esta era objeto apropriado pelas ciências da educação - Psicologias Educacionais, Sociologia da Educação e Biologia da Educação restando-lhe a questão dos seus fins e dos seus valores.

Ora, os fins da educação, em tempos onde o Estado reclama para si a liderança do processo de formação humana, em uma instituição específica - a escola pública -, que se traduz no monopólio das decisões legislativas, não são definidos nem pela sociedade, numa política de autonomia e muito menos por uma disciplina de um curso - o de Pedagogia.

Em que pese às intervenções estatais no Curso de Pedagogia - Decreto ${ }^{\circ}$. 1.190/39, Parecer CFE no. 251/62, Parecer CFE no. 252/69 e Parecer CFE nº. 632/69 -, essa obrigatoriedade prevaleceu, de forma explícita, até 2006, quando novas diretrizes curriculares do curso foram instituídas, mas sem especificação de conteúdos ou disciplinas obrigatórias. Por força da tradição, a disciplina continua a compor as matrizes curriculares da Pedagogia. 
Colocavam-se aí as questões: Instituída a disciplina, qual a sua identidade? Como componente curricular, essa construção social tinha caráter de prática reflexiva?

A identidade da disciplina Filosofia da Educação vem sendo objeto de questionamento, bem como seus conteúdos. É nesse sentido que se pode compreender os trabalhos de investigação de Albuquerque (1996 e 2002), Quilicci Neto (2001), Tomazetti (2000a) e Pereira Silva (2000).

Albuquerque (1996), em Filosofia da Educação: uma disciplina entre a dispersão de conteúdos e a busca de uma identidade, dissertação realizada na Faculdade de Educação da Universidade Federal de Minas Gerais (UFMG), investigou programas de Filosofia da Educação de 10 universidades públicas, nos anos de 1994 e 1995, e "curriculum vitae" dos professores dessas disciplinas, bem como entrevistou intelectuais afetos à área de Filosofia da Educação. Em suas conclusões, ela apontou a indeterminação de uma configuração precisa do objeto da disciplina, justificando ser essa uma disciplina recente, o que refletiu nos investimentos, em nível de produção acadêmica; a formação do professor de Filosofia da Educação como fator determinante da constituição dos programas e assuntos da disciplina; sua dispersão dos conteúdos; e a ausência de articulação entre filosofia e educação.

Quilicci Neto (2001) objetivou, em O ensino da Filosofia da Educação no Brasil: uma análise dos programas de ensino da Filosofia da Educação dos cursos de Pedagogia do Estado de São Paulo - 1988-1998, a elucidação da prática da Filosofia da Educação, analisando os objetivos, os conteúdos e programas de 12 faculdades e de um curso virtual. Ele constatou que a disciplina apresentava-se como História da Filosofia ou como análise de alguma temática educacional, com tendência à ênfase em um dos termos da locução, ficando o outro como apêndice.

Tomazetti (2000a), em sua tese de doutorado intitulada Filosofia da Educação: uma contribuição à compreensão de seu percurso no campo educacional buscou na história da educação e na história do campo educacional responder: que características definiriam o saber filosófico, no ensino normal até os anos 1930 e nos cursos de formação de professores secundários, entre as décadas de 1940 e 1960. Ela tomou como objeto programas de ensino de algumas escolas normais e de universidades, entre os anos 1940 e 1960, e concluiu que a disciplina Filosofia da Educação consistia na apresentação da história do pensamento educacional de autores clássicos e de correntes filosóficas, das quais se deduziam as implicações educacionais. Para ela, a Filosofia da Educação devia ser pensada a partir das referências: a da compreensão histórica, em que se buscam, na história da filosofia, as ideias sobre educação e a da análise da linguagem. 
Pereira Silva (2000), em Filosofia da Educação no curso de Pedagogia: referências para o debate identitário, interrogou:

[...] como seria uma proposta de conteúdos para disciplina Filosofia da Educação, fiel às especificidades da interrogação filosófica, proposta essa que pudesse contribuir numa organização interdisciplinar do curso de Pedagogia elou que fosse tangenciada pela lógica dessa interrogação? (p. 27).

O referido autor definiu como características fundamentais do conceito de filosofia: a totalidade, a busca da realidade em si, o espanto e o ruir da obviedade, o ser filha da cidade, a constituição da cidade-estado grega, as raízes do afastamento da Filosofia em relação à cidade e a filosofia da cidade como filosofia da práxis.

Como contribuição à identidade da disciplina Filosofia da Educação, ele elaborou e propôs seis critérios: os temas da disciplina deveriam contemplar os desafios educacionais sob a ótica da Filosofia, objetivando a formação do homem onilateral; o privilégio à escola, mais especificamente a escola pública, valorizando seu potencial contraideológico; a filosofia da práxis pedagógica, na qual a pergunta filosófica possibilitasse pensar a educação; o descobrimento do "currículo oculto" ocupando brechas para favorecer as minorias, os excluídos e marginalizados; uma sensibilidade interdisciplinar na proposição de conteúdos para a disciplina Filosofia da Educação e a formação de intelectuais específicos. Por fim, o citadoautor apresentou uma proposta de conteúdos para a disciplina Filosofia da Educação.

Na tese Trilhas e temas da disciplina Filosofia da Educação, a partir da PUC-SP, Albuquerque (2002) buscou compreender como a disciplina se instituiu historicamente, na década de 1940 até 1960. Usou como fontes documentos oficiais da instituição, da disciplina, os programas de ensino, textos e livros dos intelectuais nela envolvidos. A investigação inseriu-se no campo de estudos da história das disciplinas acadêmicas. Concluiu que a construção da identidade da disciplina Filosofia da Educação na PUC-SP se fez tributária dos professores que dirigiram tal cadeira e que lhe davam a conotação de sua formação.

Severino (2000b), em A Filosofia da Educação no Brasil: esboço de uma trajetória, assumiu que a Filosofia da Educação é o espaço do discurso elaborado por pensadores que tomaram a Educação como objeto de estudo e reflexão e construíram uma teoria filosófica explícita sobre ela. Esse autor identificou quatro perspectivas filosóficos-educacionais: a tecnicidade funcional da educação: ciência e técnica, bases da Pedagogia; a eticidade formativa: a educação como construção do sujeito; a educação como lugar de produção e cultivo da subjetividade desejante; e a educação como práxis construtora da história: a dimensão da politicidade da prática pedagógica. 
A Filosofia da Educação tem, para Severino (1993 e 2001), três tarefas: epistemológica, axiológica e ontológica, que podem ser sintetizadas na construção de uma imagem do homem e no delineamento do sentido da existência humana com relação à educação. No ensaio A busca do sentido da formação humana: tarefa da Filosofia da Educação, defendeu a educação como formação cultural, como síntese superadora da educação como formação ética e como formação política.

Ainda, no artigo A Filosofia da Educação: buscando o sentido histórico e social da educação, o autor a propôs como uma antropologia, um lugar de síntese, por situar a educação em relação à existência humana, devendo operar com as contribuições de todas as ciências da educação.

Valle apresentou outra perspectiva para a Filosofia da Educação, a partir da obra de Cornelius Castoriadis. E, em ambos os teóricos, buscou-se apoio para estruturar esta investigação.

Castoriadis concebeu a filosofia como interrogação aberta e incessante, como criadora dos sentidos que erigem o mundo próprio do sujeito e o mundo coletivo do socialhistórico, e afirmou que a pratica para salvar o próprio pensamento e a coerência. Portanto, a atividade de filosofar pode e deveria ser realizada por cada um que o desejar e buscar submeter a exame crítico o que recebeu da psique, da história e das instituições do socialhistórico. Isso joga por terra a ideia de que a filosofia é atribuição/disposição específica dos experts, produtores de teoria.

Para aquele autor, três atividades são impossíveis - a psicanálise, a educação e a política -, e ele as denomina prático-poiéticas, pois devem fazer surgir a autonomia, apoiando-se numa autonomia que ainda não existe, e têm como objetivo a formação humana, a autotransformação.

Embora Castoriadis não tenha teoria específica sobre Filosofia da Educação, Valle prestou honras ao Mestre Filósofo, tomando sua teoria como criação de interrogações que alimentam o pensamento. Tais interrogações sobre a sociedade, a concepção de educação, do aluno, do professor, sobre a própria natureza do humano deveriam ser praticadas pelo coletivo da educação. Mas não é o que acontece, pois aquele que desempenha a função de professor, em consequência de seu próprio processo formativo, da dicotomia entre teoria e prática, de seu conformismo e submissão ao instituído, pediu demissão daquilo que é mais caro ao humano - a atividade do pensamento. Assim, as questões que se colocam são: Como tornar essas interrogações permanentemente abertas e presentes no cotidiano educacional? Como 
levar o coletivo da educação a construir a disposição para interrogação sobre seu pensar e seu fazer?

Pensa-se que a Filosofia da Educação é uma possibilidade de contribuição para tal, motivo pelo qual foi eleita como objeto desta investigação.

O material empírico foi tomado do Curso de Pedagogia da Universidade Federal de Viçosa (UFV), que em geral guarda identificação/semelhança com seus congêneres em outras instituições.

O Curso de Pedagogia foi criado em 1971 pelo Ato nº 17/71, do Conselho de Ensino, Pesquisa e Extensão da UFV. Nasceu vinculado ao Departamento de Metodologia da Escola Superior de Ciências Domésticas (ESCD), que não era alocada na área de Humanas, mas constituía parte integrante das Ciências Agrárias.

Como objeto desta investigação tomou-se no Curso de Pedagogia da UFV as disciplinas de Filosofia da Educação, que, em número de quatro, compunham a matriz curricular do curso. Elas eram alocadas nos períodos iniciais do curso, e seus programas analíticos foram elaborados pelo Professor Guy Capdeville. Eles vigiram até 1980, com alterações apenas nos códigos, e não no conteúdo.

No período de 1972 a 2008, quatro reformulações nos programas analíticos dessas disciplinas se realizaram em 1980, 1990, 2000 e 2008, assumindo a internalização dos conteúdos apresentados e não uma interrogação sobre eles, para oportunizar o pensamento crítico-reflexivo. Pensa-se que a estrutura e o conteúdo das disciplinas de Filosofia da Educação, como estavam organizados, não potencializavam a interrogação e nem a possibilidade de construção da autonomia pelos educandos.

Em geral, a disciplina historicamente era organizada e ministrada como estudo de sistemas filosóficos, para deles se deduzir concepções de homem, de educação, de conhecimento, de valores e finalidades, o que imprimia caráter de "aplicação de doutrinas filosóficas "puras"”, ao campo educacional, evidenciando suas consequências e implicações. Esta perspectiva que assumia a Filosofia da Educação dava-lhe conotação de história da Filosofia.

Todavia, sendo tal disciplina resultante da construção do professor que a ministra, dando-lhe a identidade, faz-se necessário questionar: quem é o professor de Filosofia da Educação? Qual sua formação? Ela viabiliza sua atuação na disciplina?

Embora a disciplina seja, geralmente, representada e pensada, por aqueles que lhe são afetos, como análise, reflexão e crítica sobre a educação, não tem sido assim o modo como se concretiza. Os discursos sobre ela tornaram-se "chavões", que em nada contribuem para a 
construção da autonomia dos educandos. Pelo contrário, assumindo tal discurso, eles se mantêm na heteronomia instituída, assumem o pensamento já feito e não o pensamento “criação" e esconjuram a mortalidade de si e das instituições.

Justificou-se, portanto, o título desta investigação: Filosofia da educação na formação do pedagogo: discurso de autonomia e fabricação da heteronomia.

Isso foi o que motivou buscar as contribuições de Castoriadis e Valle. Assumiu-se, com eles, que a Filosofia da Educação que pode contribuir para a construção do sujeito reflexivo e deliberante e do espaço democrático é aquela que se interroga incessantemente.

Como contribuição desta tese, propõe-se que a disciplina em estudo comporte: a instalação de uma crise das verdades e das certezas dos educadores e dos educandos; a manifestação do desejo de autonomia/cidadania/democracia; o estudo/conhecimento da história da Filosofia da Educação; a construção, pelo educador, de um projeto para os seus educandos; a prestação de contas públicas pelo educador, do que pensa, diz e faz de sua prática educativa e a interrogação ilimitada de si, do outro e da sociedade - das significações imaginárias sociais - pelo educador e pelos educandos.

Pensa-se, ainda, que o professor de Filosofia da Educação, ao assumir que seu fazer é uma atividade prático-poiética, com tudo que ela comporta, assumirá, também, a responsabilidade de suas ações. 


\section{REFERÊNCIAS}

Abbagnano, N.; Visalberghi, A. Historia de la Pedagogia. México: Fondo de Cultura Econômica, 1964.

ALBUQUERQUE, Maria Betânia Barbosa. Filosofia da educação: uma disciplina entre a dispersão de conteúdos e a busca de uma identidade. 1996. Dissertação (Mestrado em Educação) - Universidade Federal de Minas Gerais, Belo Horizonte, MG.

Trilhas e temas da disciplina filosofia da educação a partir da PUC-SP. 2002. Tese (Doutorado) - Pontifícia Universidade Católica de São Paulo, São Paulo, SP.

ALBUQUERQUE, Maria Betânia Barbosa; OLIVEIRA, Ivanilde Apoluceno de; SANTIAGO, Joelciléa de Lima Ayres. Filosofia da educação: produção intelectual, identidade e ensino a partir da ANPED. Belém: EDUEPA-UEPA, 2006.

ARANHA, Maria Lúcia de A. Filosofia da educação. 3. ed. São Paulo: Moderna, 2006.

ARENDT, Hannah. Entre o passado e o futuro. 5. ed. São Paulo: Perspectiva, 2005.

ALVES, D. J. O espaço da filosofia no currículo do ensino médio a partir da nova LDB (Lei n. ${ }^{\circ}$ 9.394/96): análise e reflexões. 2000. Dissertação (Mestrado em Educação) Universidade de Campinas, Campinas, SP.

ARRUDA, Francimar Duarte. Imaginário social e educação: fundamentos filosóficos. 1993. Tese (Doutorado em Educação) - Universidade Federal do Rio de Janeiro, Rio de Janeiro, RJ.

AZEVEDO, F. A educação e seus problemas. 4. ed. São Paulo: Melhoramentos, s.d. Tomo I.

A educação e seus problemas. 4. ed. São Paulo: Melhoramentos, s.d. Tomo II.

BARROS, Gilda N. Maciel de. História e filosofia da educação na USP: origens. Referências para a memória da Feusp. Cadernos de História e Filosofia da Educação, São Paulo, v. 1, n. 1, p. 11-36, 1993.

BELLOCHIO, C. R. et. al. Profissão docente: algumas dimensões e tendências. Revista do Centro de Educação, Santa Maria, v. 20, n. 2, p. 1-15, 2004.

BISSOLli DA SILVA, Carmem. S. Curso de Pedagogia no Brasil: história e identidade. 2.ed. Campinas: Autores Associados, 2003.

BOÉTIE, Etienne la. Discurso da servidão voluntária. São Paulo: Brasiliense, 1982. 
BONTEMPI JÚNIOR, B. A cadeira de história e filosofia da educação da USP entre os anos 40 e 60: um estudo das relações entre a vida acadêmica e a grande imprensa. 2001. Tese (Doutorado) - Pontifícia Universidade Católica de São Paulo, São Paulo, SP.

BRANDÃO, Carlos Rodrigues (Org.). O educador: vida e morte. 2.ed. Rio de Janeiro: Graal. 1982.

BRASIL. Constituição Política do Império do Brazil (de 25 de março de 1824). $\overline{1891) .}$ Constituição da República dos Estados Unidos do Brasil (de 24 de fevereiro de (891). 1934).

Constituição da República dos Estados Unidos do Brasil ( de 16 de julho de (1934). Brasília, 1931.

Decreto n. ${ }^{\circ}$ 19.859, de 11 de abril de 1931. Cria o Conselho Nacional de Educação.

Decreto n.․ 19.851, de 11 de abril de 1931. Dispõe que, o ensino superior no Brasil obedecerá, de preferência, ao sistema universitário, podendo ainda ser ministrado em institutos isolados, e que a organização técnica e administrativa das universidades é instituída no presente decreto, regendo-se os institutos isolados pelos respectivos regulamentos, observados os dispositivos do seguinte Estatutos das Universidades Brasileiras. Brasília, 1931.

Decreto n. ${ }^{\circ}$ 19.852, de 11 de abril de 1931. Dispõe sobre a organização da universidade do Rio de Janeiro. Brasília, 1931.

Decreto-Lei n.․ 1.190, de 4 de abril de 1939. Dá organização à Faculdade Nacional de Filosofia. Brasília, 1939.

Decreto-Lei n. ${ }^{0}$ 1.063, de 20 de janeiro de 1939. Dispõe sobre a transferência de estabelecimentos de ensino da Universidade do Distrito Federal para a Universidade do Brasil. Brasília, 1939.

Brasília, 1946.

Decreto-Lei n. ${ }^{\circ}$ 8.530, de 02 de janeiro de 1946. Lei Orgânica do Ensino Normal.

Parecer n. ${ }^{\circ}$ 251, de 1963, do Conselho Federal de Educação. Fixa o currículo mínimo e a duração do curso de Pedagogia. Brasília, 1963.

Lei n. ${ }^{\circ}$. 5.540, de 28 de novembro de 1968. Fixa normas de organização e funcionamento do ensino superior e sua articulação com a escola média, e dá outras providências. Brasília, 1968. 
Resolução n. ${ }^{\circ}$. 2, de 12 de maio de 1969, do Conselho Federal de Educação. Fixa os mínimos de conteúdo e duração do curso de Pedagogia. Brasília, 1969.

Parecer n. ${ }^{\circ}$ 252, de 1969, do Conselho Federal de Educação. Currículo de Pedagogia: Estudos pedagógicos superiores. Mínimos de currículo e duração para o curso de graduação em Pedagogia. Brasília, 1969.

Parecer n. . 632, de 1969, do Conselho Federal de Educação. Conteúdo específico da Faculdade de Educação. Brasília, 1969.

Lei n. ${ }^{\circ}$ 9.394, de 20 de dezembro de 1996. Estabelece as diretrizes e bases da educação nacional. Brasília, 1996.

- Ministério da Educação e Cultura. Documento da Comissão de Especialistas de Pedagogia -Portaria MEC 641/97. Brasília, 1997.

Parecer n.․ 67, de 2003, do Conselho Nacional de Educação/Câmara de Educação Superior. Referencial para as Diretrizes Curriculares Nacionais - DCN dos Cursos de Graduação. Brasília, 2003.

Parecer n. ${ }^{\circ}$ 05, de 2005, do Conselho Nacional de Educação/Conselho Pleno. Diretrizes Curriculares Nacionais para o curso de Pedagogia. Brasília, 2005.

Resolução n.․ 01, de 2006, do Conselho Nacional de Educação/Conselho Pleno. Institui Diretrizes Curriculares Nacionais para o Curso de Graduação em Pedagogia, licenciatura. Brasília, 2006.

Parecer n. ${ }^{\circ}$ 3, de 2006, do Conselho Nacional de Educação/Conselho Pleno. Reexame do Parecer CNE/CP n. ${ }^{\circ}$. 5/2005, que trata das Diretrizes Curriculares para o Curso de Pedagogia. Brasília, 2006.

CFE, Documenta nº. 100, p. 106-107.

CADERNOS DE HISTÓRIA E FILOSOFIA DA EDUCAÇÃO, São Paulo, v. 1, n. 1, 1993.

CAMBI, Franco. História da Pedagogia. São Paulo: FEU, 1999.

CAPDEVILLE, Guy. O ensino superior agrícola no Brasil. Viçosa: UFV, 1991.

CARTOLANO, Maria T. P. Filosofia no ensino de $2 .^{\circ}$ grau. São Paulo: Cortez/Autores Associados, 1985.

CASTORIADIS, Cornelius. A instituição imaginária da sociedade. 3.ed. Rio de Janeiro: Paz e Terra, 1982.

As encruzilhadas do labirinto I. 2.ed. Rio de Janeiro: Paz e Terra, 1987a. 
As encruzilhadas do labirinto 2: os domínios do homem. Rio de Janeiro: Paz e Terra, 1987b.

As encruzilhadas do labirinto 3: o mundo fragmentado. Rio de Janeiro: Paz e Terra, 1992.

As encruzilhadas do labirinto IV: a ascensão da insignificância. São Paulo: Paz e Terra, 2002.

Feito e a ser feito: as encruzilhadas do labirinto V. Rio de Janeiro: DP\&A, 1999.

Figuras do pensável: as encruzilhadas do labirinto VI. Rio de Janeiro: Civilização Brasileira, 2004.

CHAVES, E. C. O curso de pedagogia: um breve histórico e um resumo da situação atual. Cadernos do CEDES, São Paulo, 1989.

CHAUI, Marilena. Ética e universidade. Ciência Hoje, v. 18, n. 102, p. 39-42, ago. 1994a.

. Convite à filosofia. São Paulo: Ática, 1994b.

COELHO, Ildeu Moreira. Filosofia e educação. In: PEIXOTO, A. J. (Org.). Filosofia, educação e cidadania. Campinas: Alínea, 2001.

CONTI, C. L. A. Imagens da profissão docente: um estudo sobre professoras primárias em início de carreira. 2003. Tese (Doutorado em Educação) - Universidade de Campinas, Campinas, SP.

CORDEIRO, Alexandre F.; VIEIRA, Raphael D. S. (Orgs.). Índice remissivo: estatuto da UFV, regimento-geral e resoluções do CONSU. Viçosa: UFV/PRJ, 2006.

CÓRDOVA, R. de A. Instituição, educação e autonomia na obra de Cornelius Castoriadis. Brasília: Plano, 2004.

CURY, Carlos. R. Jamil. Ideologia e educação brasileira: católicos e liberais. 4.ed. São Paulo: Cortez/Autores Associados, 1988.

Cidadania republicana e educação: Governo Provisório do Mal. Deodoro e Congresso Constituinte de 1890-1891. Rio de Janeiro: DP\&A, 2001.

DEBORD, Guy. Sociedade do espetáculo. Rio de Janeiro: Contraponto, 2004.

EVANGELISTA, O. Formar o mestre na universidade: a experiência paulista nos anos de 1930. Educação e Pesquisa, São Paulo, v. 27, n. 2, p. 247-259, jul./dez. 2001. 
FARIA, Jandira Nunes de. Do individuo privatizado ao sujeito ético: breve passagem da educação pelo pensamento de Cornelius Castoriadis. 2000. Dissertação (Mestrado em Educação) - Universidade Federal de Santa Catarina, Florianópolis, SC.

FÁVERO, Maria de L. de A. (Coord.). Faculdade nacional de filosofia: projeto ou trama universitária? Rio de Janeiro: UFRJ, 1989.

FENELON, Dea. Pesquisa em História: perspectivas e abordagens - metodologia de pesquisa educacional. São Paulo: Cortez. 1989.

FERREIRA, Aurélio B.de H. Novo dicionário eletrônico Aurélio - versão 5.0. 3.ed. Positivo Informativa Ltda., 2004.

FERNANDES, Florestan. O desafio educacional. São Paulo: Cortez: Autores Associados, 1980.

FÉTIZON, Beatriz A. de Mora. Faculdade de Educação: antecedentes e origens. Estudos Avançados, v. 8, n. 22, 1994.

FLICKINGER, Hans-Georg. Para que filosofia da educação. Perspectiva, Florianópolis, v. 16, n. 29, p. 15-22, jan./jun. 1998.

FRANÇA, Fernando César. T. Criação e dialética: o pensamento histórico-político de Cornelius Castoriadis. São Paulo: EDUSP/Brasiliense, 1996.

FREIRE, Paulo. Pedagogia da autonomia: saberes necessários à prática educativa. São Paulo: Paz e Terra, 1997.

FULLAT, Octavi. Filosofias de la educación. Barcelona: Ediciones CEAC, 1994.

Filosofias da educação. Petrópolis: Vozes, 1994.

GADOTTI, Moacir. Pedagogia da práxis. São Paulo: Cortez/Instituto Paulo Freire, 1995.

Educação e poder: introdução à pedagogia do conflito. 10.ed. São Paulo: Cortez, Autores Associados, 1991.

História das ideias pedagógicas. São Paulo: Ática, 1993.

GALLO, Silvio. Filosofia, educação e cidadania. In: PEIXOTO, A. J. (Org.). Filosofia, educação e cidadania. Campinas: Alínea, 2001.

GAUTHIER, C. et al. Por uma teoria da pedagogia: pesquisas contemporâneas sobre o saber docente. Ijuí: UNIJUI, 1998. 
GENRO, Maria. Elly H. A filosofia da educação na busca da autonomia intelectual dos educadores. 1992. Dissertação (Mestrado em Educação) - Pontifícia Universidade Católica do Rio Grande do Sul, Porto Alegre, RS.

GHIRALDELli JUNIOR, Paulo (Org.). O que é filosofia da educação? 2.ed. Rio de Janeiro: DP\&A, 2000.

Filosofia da educação. 2.ed. Rio de Janeiro: DP\&A, 2002.

Filosofia da educação. São Paulo: Ática, 2006.

GILLES, T. R. Filosofia da educação. São Paulo: EPE, 1983.

GIROUX, H. A. Os professores como intelectuais: rumo a uma pedagogia crítica da aprendizagem. Porto Alegre: Artes Médicas, 1997.

HOLLOWAY, J. Mudar o mundo sem tomar o poder. São Paulo: Viramundo, 2003.

JAEGER, Werner W. Paidéia: a formação do homem grego. 3.ed. São Paulo: Martins Fontes, 1994.

JAPIASSU, Hilton. Um desafio à filosofia: pensar-se nos dias de hoje. São Paulo: Letras \& Letras, 1997.

KANT, Immanuel. Sobre a pedagogia. Piracicaba: UNIMEP, 1996.

KATSIOS, K. A. A. Um estudo sobre o curso de pedagogia da faculdade de filosofia, ciências e letras da universidade de São Paulo (1940-1969). 1999. Dissertação (Mestrado) - Pontifícia Universidade Católica de São Paulo, São Paulo, SP.

KNELLER, George. F. Introdução à filosofia da educação. 4.ed. Rio de Janeiro: Zahar, 1964.

Introdução à filosofia da educação. 5.ed. Rio de Janeiro: Zahar, 1979.

LARA, Tiago A. Filosofia e Filosofia da Educação. Educação e Filosofia, Uberlândia, v. 2, n. 3, p. 15-24, jul./dez. 1987.

LAUWERYS, J. Instalação e desenvolvimento das faculdades de educação no Brasil. Revista Brasileira de Estudos Pedagógicos, Rio de Janeiro, v. 51, n. 113, jan./mar. 1969.

LEDESMA, Lilian Valentina R. Filosofia, educação e cotidiano na formação do educador: interpretações críticas das vivências e representações dos alunos de Pedagogia da UNICAMP. Campinas: Faculdade de Educação da UNICAMP, 2000. 
LEITE, C. D. P. Labirinto: infância, linguagem e escola. 2002. Tese (Doutorado) Universidade de Campinas, Campinas, SP.

LIMA, L. C. A escola como organização educativa: uma abordagem sociológica. São Paulo: Cortez, 2001.

LOURENO FILHO, M. B. A formação de professores: da escola normal à escola de educação. Brasília: INEP, 2001.

LUCKESI, C. C. Filosofia da educação. São Paulo: Cortez, 1990.

Filosofia, exercício do filosofar e prática educativa. Em Aberto, Brasília, n. 45, p. 35-43, jan./mar. 1990.

MACIEL, Mirtes Mirian Amorin. Socialismo e autonomia: Castoriadis e a instituição imaginária da sociedade. 1987. Tese (Doutorado) - Faculdade de Filosofia, Letras e Ciências Humanas, Universidade de São Paulo, SP.

MACHADO, V. L. de C. O projeto pedagógico da faculdade de educação da PUCCAMP: seus pressupostos filosóficos e pedagógicos. 1993. Dissertação (Mestrado em Educação) Pontifícia Universidade Católica de Campinas, Campinas, SP.

MARQUES, M. O. A formação do profisssional da educação. Ijuí: Ed. Unijuí, 1992.

MARQUES, Nerina A. C. Reflexões sobre economia doméstica: origens e caminhos. Oikos, Viçosa, v. 8, n. 1, p. 46-53, 1993.

MARTINS, A M. Autonomia e educação: a trajetória de um conceito. Cadernos de Pesquisa, n. 115, p. 207-232, mar. 2002.

MARTINS, E. C. A Filosofia da Educação na actualidade. Educação e Filosofia, Uberlândia, v. 13, n. 7, p. 155-178, jan./jun. 1993.

O conceito de emancipação como uma nova meta educativa na formação humana. Educação e Filosofia, Uberlândia, v. 7, n. 14, p. 39-59, 1993.

MATOS, Olgária. Filosofia a polifonia da razão: filosofia e educação. São Paulo: Scipione, 1997.

MENDES, Dumerval Trigueiro (Coord.). Filosofia da educação brasileira. Rio de Janeiro: Civilização Brasileira, 1983.

Existe uma filosofia da educação brasileira? In: MENDES, D. T. (Coord.). Filosofia da educação brasileira. Rio de Janeiro: Civilização Brasileira, 1983. 
MENEZES, Luiz Carlos (Org.). Professores: formação e profissão. Campinas/São Paulo: Autores Associados/NUPES, 1996.

MÉSZÁROS, I. A educação para além do capital. São Paulo: Boitempo, 2005.

MIALCHI, N. M. da R. A formação do profissional para a educação básica: o instituto superior de educação e o curso de pedagogia em disputa. 2003. Dissertação (Mestrado em Educação) - Faculdade de Educação da UNICAMP, Campinas, SP.

MONARCHA, Carlos. As três fontes da pedagogia científica: a psicologia, a sociologia e a biologia. Didática, São Paulo, v. 28, p. 41-49, 1992.

MOREIRA, Antônio Flávio B. Conhecimento educacional e formação do professor. 2.ed. Campinas: Papirus, 1985.

OLIVEIRA, M. A. M. O ensino da filosofia no $2 .^{\circ}$ grau da escola brasileira: um percurso histórico, até a realidade mineira dos anos 80. 1993. Dissertação (Mestrado em Educação) Faculdade de Educação da Pontifícia Universidade Católica de Campinas, Campinas, SP.

PALOCCI, H. da S. Educação, cidadania e interdisciplinaridade: estudo das vivências e representações sociais dos espaços urbanos em Ribeiro Preto-SP como metodologia de formação política construída com alunos da educação fundamental. 2003. Tese (Doutorado em Educação) - Universidade de Campinas, Campinas, SP.

PECHULA, Marli A. A filosofia no ensino médio: da importância anunciada à descaracterização praticada. 2001. Dissertação (Mestrado em Educação) - Universidade de Campinas, Campinas, SP.

PEIXOTO, Adão José (Org.). Filosofia, educação e cidadania. Campinas: Alínea, 2001.

PEREIRA, L.; FORACCHI, M. M. Educação e sociedade. 11. ed. São Paulo: Nacional, 1983.

PEREIRA da SILVA, Sérgio. A disciplina filosofia da educação no curso de pedagogia: referências para o debate identitário. 2000. Tese (Doutorado em Educação) - Pontifícia Universidade Católica de São Paulo, São Paulo, SP.

PERISSÉ, Gabriel. Introdução à Filosofia da Educação. Belo Horizonte: Autêntica, 2008.

RANCIÈRE, Jacques. O mestre ignorante - cinco lições sobre a emancipação intelectual. 2.ed. Belo horizonte: Autêntica, 2004.

REVISTA BRASILEIRA DE ESTUDOS PEDAGÓGICOS, Rio de Janeiro, v. 51, n. 113, jan./mar. 1969. 
ROCHA, Dorothy (Org.). Filosofia da educação: diferentes abordagens. Campinas: Papirus, 2004.

Projeto pedagógico: ensaio de uma abordagem filosófica. In: ROCHA, Dorothy

(Org.). Filosofia da educação: diferentes abordagens. Campinas: Papirus, 2004.

RODRIGUES, Rogério. A educação cindida e a formação do sujeito: para além de uma pedagogia do "bem" e do "mal”. 2004. Tese (Doutorado em Educação) - Universidade de Campinas, Campinas, SP.

ROMANELli, Otaíza de Oliveira. História da educação no Brasil (1930/1973). 11.ed. Petrópolis: Vozes, 1989.

ROMÃO, Arquilau Moreira. A filosofia no ensino médio como questionamento histórico e existencial. 2003. Dissertação (Mestrado em Educação) - Universidade de Campinas, Campinas, SP.

QUILLICI NETO, Armindo. O ensino de filosofia da educação no Brasil: uma análise dos programas de ensino de filosofia da educação dos cursos de pedagogia do Estado de São Paulo. 2001. Tese (Doutorado em Educação) - Universidade de Campinas, Campinas, SP.

SAVIANI, Dermeval. Do senso comum à consciência filosófica. São Paulo: Cortez, 1982.

História da formação docente no Brasil: três momentos decisivos. Educação/Centro de Educação/UFSM, Santa Maria, v. 30, n. 2, p. 1-13, 2005.

A contribuição da filosofia para a educação. Em Aberto, Brasília, n. 45, p. 3-9, jan./mar. 1990.

Tendências e correntes da educação brasileira. In: MENDES, Demerval Trigueiro (Coord.). Filosofia da educação brasileira. Rio de Janeiro: Civilização Brasileira, 1983.

SETTON, M. da G. J. A particularidade do processo de socialização contemporâneo. Tempo Social - Revista de Sociologia da USP, v. 17, n. 2, p. 335-350, 2005.

SEVERINO, Antônio Joaquim. Filosofia da educação: construindo a cidadania. São Paulo: FTD, 1994.

A filosofia da educação: buscando o sentido histórico e social da educação. Educação e Filosofia, Uberlândia, v. 10, n. 20, p. 67-75, jul./dez. 1996.

A filosofia contemporânea no Brasil: conhecimento, política e educação. Petrópolis: Vozes, 1997. 
A educação, o sujeito e a história: identidade e tarefas da filosofia da educação. 2000a. Tese (Livre Docência) - Faculdade de Educação da Universidade de São Paulo, São Paulo, SP.

. Educação, sujeito e história. São Paulo: Olho d'Água, 2001.

A busca do sentido da formação humana: tarefa da filosofia da educação. Educação e Pesquisa, São Paulo, v. 32, n. 3, p. 619-634, set./dez. 2006a..

. A filosofia da educação no Brasil: esboço de uma trajetória. In: GHIRALDELLI, P. (Org.). O que é filosofia da educação? 2.ed. Rio de Janeiro: DP\&A, 2000 b.

. Fundamentos éticos-políticos da educação no Brasil de hoje. In: LIMA, Júlio C. F. (Org.). Fundamentos da educação escolar do Brasil. Rio de Janeiro: FIOCRUZ, 2006 b.

A compreensão filosófica do educar e a construção da filosofia da educação. In: ROCHA, D. (Org.). Filosofia da educação: diferentes abordagens. Campinas: Papirus, 2004.

Proposta de um universo temático para a investigação em Filosofia da Educação: as implicações da historicidade. Perspectiva, Florianópolis, ano 11, n. 19, p. 11-27, 1993a.

Paradigmas filosóficos e conhecimento da educação: limites do atual discurso filosófico no Brasil na abordagem da temática educacional. Revista Brasileira de Estudos Pedagógicos, Brasília, v. 74, n. 176, p. 131-153, jan./abr. 1993 b.

A contribuição da filosofia para a educação. Em Aberto, Brasília, n. 45, p. 19-25, jan./mar. 1990.

Filosofia. São Paulo: Cortez, 1992.

SILVA, Edison Antônio da. A formação da disciplina filosofia no ensino médio brasileiro (1980-2000). 2001. Dissertação (Mestrado em Educação) - Universidade de São Paulo, São Paulo, SP.

SILVA, Marcelo Donizete da. O ensino da filosofia da educação no ensino médio em Campinas-SP: da crise de identidade à desestruturação institucional pós LDBN. 2003. Dissertação (Mestrado em Educação) - Universidade de Campinas, Campinas, SP.

SILVA, Tomaz T. da (Org.). O sujeito da educação: estudos foucaultianos. Petrópolis: Vozes, 1994.

SUCUPIRA, Newton. Da faculdade de filosofia à faculdade de educação. Revista Brasileira de Estudos Pedagógicos, Rio de Janeiro, v. 51, n. 113, p. 261-276, 1969. 
TANURI, Leonor M. História da formação de professores. Revista Brasileira de Educação, n. 14, p. 61-88, maio/jun./jul./ago. 2000.

TEIXEIRA, Anísio S. Pequena introdução à filosofia da educação: a escola progressiva ou a transformação da escola. 6.ed. São Paulo: Editora Nacional, 1971.

Escolas de educação. Revista Brasileira de Estudos Pedagógicos, Rio de Janeiro, v. 51, n. 113, p. 239-259, 1969.

TOMAZETTI, Elisete M. Filosofia da educação: uma contribuição à compreensão de seu percurso no campo educacional. 2000a. Tese (Doutorado em Educação) - Universidade de São Paulo, SP.

Anísio Teixeira: alguns apontamentos em comemoração ao centenário de seu nascimento. Centro de Educação, Santa Maria, v. 25, n. 2, 2000 b.

. Filosofia da Educação em algumas universidades brasileiras: entre os anos 40 e os anos 60. Perspectiva, Florianópolis, v. 19, n. 2, p. 443-467, jul./dez.. 2001.

UNIVERSIDADE FEDERAL DE VIÇOSA - UFV. CEPE - Atas do Conselho de Ensino, Pesquisa e Extensão. Viçosa: UFV, 1970-2008.

. CTG - Atas do Conselho de Graduação. Viçosa: UFV, 1970-2008.

CCH - Atas da Câmara de Ensino do Centro de Ciências Humanas, Letras e Artes. Viçosa: UFV, 1970-2008.

. Catálogos de Graduação. Viçosa: UFV, 1972-2008.

Portarias (Processo 012079/2003). Viçosa: UFV, 2003.

Projeto político pedagógico do curso de Pedagogia (Processo n. 011770-99). Viçosa: UFV, 1999.

Projeto político pedagógico do curso de Pedagogia (Processo 009279/2007). Viçosa: UFV, 2007.

UFV, 2002.

Reformulação do Curso de Pedagogia (propostas) (Processo 6097/02). Viçosa:

Resolução do CEPE n. ${ }^{\circ}$ 15/1999. Viçosa: UFV, 1999.

Banco de dados de ensino. Disponível em: <http://www.cpd.ufv.br/ensino>.

. Sistema gestor de pesquisa. Disponível em: 〈http://cpd.ufv.br/pesquisa〉. 
Publicações envolvendo docentes. Disponível em: 〈http://cpd.ufv.br/publicações〉.

2008.

DPE - atas do colegiado do Departamento de Educação. Viçosa: UFV, 1972-

ESED - Ata n. ${ }^{\circ}$ 4, de 28 de dezembro de 1971, da Escola Superior de Economia Doméstica. Viçosa: UFV, 1971.

VALLE, Lilian Aragão B. do. A escola imaginária. Rio de Janeiro: DP\&A, 1997a.

A escola e a nação: as origens do projeto pedagógico brasileiro. São Paulo: Letras \& Letras, $1997 b$.

Imaginário e Filosofia: a educação como emancipação. In: VIEIRA, M. de M. (Org.). Filosofia, educação e imaginário social. Viçosa: UFV; Belo Horizonte: FAPEMIG, 1998.

(Org.). O mesmo e o outro da cidadania. Rio de Janeiro: DP\&A, 2000a.

Cidadania e escola pública. In: VALLE, L.A. do (Org.). O mesmo e o outro da cidadania. Rio de Janeiro: DP\&A, 2000 b.

A educação como enigma e como atividade prático-poiética: implicações para o ensino da Filosofia da Educação. Perspectiva, Florianópolis, v. 18, n. 34, p. 33-47, jul./dez. 2000c.

Modelos de cidadania e discursos sobre a educação. In: PEIXOTO, A. J. (Org.). Filosofia, educação e cidadania. Campinas: Alínea, 2001.

Os enigmas da educação: a paidéia democrática entre Platão e Castoriadis. Belo Horizonte: Autêntica, 2002.

. Teoria, determinação, complexidade: desafios da reflexão sobre educação. Trabalho, Educação e Saúde, Rio de Janeiro, v. 1, n. 2, p. 9-25, 2003.

Castoriadis: uma filosofia para a educação. Educação e Sociedade, Campinas, v. 29, n. 103, p. 493-513, maio/ago. 2008.

Ainda sobre a formação do cidadão: é possível ensinar a ética? Educação e Sociedade, Campinas, v. 22, n. 76, p. 175-196, 2001.

VALENTIM, L. M. S. A filosofia da educação na sala de aula da universidade: um estudo de caso. 2001. Dissertação (Mestrado) - Universidade Federal de São Carlos, São Carlos, SP.

VASQUEZ, Adolfo Sánchez. Filosofia da práxis. 2.ed. Rio de Janeiro: Paz e Terra, 1977. 
VAZ, Henrique Cláudio de Lima. Antropologia filosófica I. São Paulo: Loyola, 1991.

VON ZUBEN, Newton. A. Filosofia e Educação. Em Aberto, Brasília, n. 45, p. 11-18, jan./mar. 1990.

XAVIER, Maria Elisabeth Sampaio P. Capitalismo e escola no Brasil: a constituição do liberalismo em ideologia educacional e as reformas do ensino (1031-1061). Campinas: Papirus, 1990.

WARDE, Mirian J. A favor da educação, contra a positivação da Filosofia. Em Aberto, Brasília, n. 45, p. 27-33, jan./mar. 1990.

Liberalismo e educação. 1984. Tese (Doutorado) - Pontifícia Universidade Católica de São Paulo, São Paulo, SP. 


\section{ANEXOS \\ ANEXO A \\ AS DISCIPLINAS DE FILOSOFIA DA EDUCACÃO NOS CATÁLOGOS DE GRADUACÃO DA UFV}

\section{A1 - Catálogo de Graduação de 1972, 1973 e 1974}

\begin{tabular}{|c|c|}
\hline EMENTAS & PROGRAMAS ANALÍTICOS \\
\hline $\begin{array}{l}\text { PED } 145 \text { - Filosofia da Educação I } \\
\text { A Filosofia: objetivo, natureza e relações com as } \\
\text { demais ciências; seu desenvolvimento histórico } \\
\text { e as principais correntes da filosofia } \\
\text { contemporânea. O problema do conhecimento. }\end{array}$ & $\begin{array}{l}\text { PED 145 - Filosofia da Educação I } \\
\text { Introdução: o conhecimento humano. A situação da } \\
\text { Filosofia, Filosofia: conceito e objeto, Filosofia: divisão. } \\
\text { História da Filosofia: momento pré-filosófico, filosofia } \\
\text { grega, sofística e Sócrates, Platão e Aristóteles. Lógica, } \\
\text { Descoberta da razão: dualismo, racionalismo, ontologia } \\
\text { racional, idealismo. Do "cogito" cartesiano à "critica" } \\
\text { kantiana. Maine de Biran, Fichte, Hegel e Bérgson. }\end{array}$ \\
\hline $\begin{array}{l}\text { PED } 146 \text { - Filosofia da Educação II } \\
\text { O problema do ser. A transcendentalidade. } \\
\text { Filosofia do comportamento. Filosofia do valor. } \\
\text { O homem e a educação. A pessoa humana e seus } \\
\text { fins. Moralidade. }\end{array}$ & $\begin{array}{l}\text { PED } 146 \text { - Filosofia da Educação II } \\
\text { A Ciência, A Metafísica, A Ética e a Arte. }\end{array}$ \\
\hline $\begin{array}{l}\text { PED } 147 \text { - Filosofia da Educação III } \\
\text { O educando: o homem; o homem e o mundo; a } \\
\text { pessoa humana e suas operações características; } \\
\text { a dependência social da pessoa humana; } \\
\text { teleologia e pessoa humana; a educação: } \\
\text { atividade de aperfeiçoamento. Implicações da } \\
\text { educação na liberdade. }\end{array}$ & $\begin{array}{l}\text { PED } 147 \text { - Filosofia da Educação III } \\
\text { Fundamentos Filosóficos da Educação (Filosofia e } \\
\text { Educação, Educação e finalidade, o homem, ser educável). } \\
\text { Principais correntes filosóficas sobre a Educação } \\
\text { (Naturalismo e Educação e correntes da filosofia moderna } \\
\text { e Educação). Totalitarismo e Educação, Democracias e } \\
\text { Educação. }\end{array}$ \\
\hline $\begin{array}{l}\text { PED } 148 \text { - Filosofia da Educação IV } \\
\text { A aprendizagem frente à liberdade humana. O } \\
\text { homem, ser perceptível; a realidade do homem- } \\
\text { animal; o homem, ser solidário. Os agentes da } \\
\text { educação: o homem, a família e o estado. A } \\
\text { educação e as instituições religiosas. }\end{array}$ & $\begin{array}{l}\text { PED } 148 \text { - Filosofia da Educação IV } \\
\text { Fundamentos Filosóficos da Educação (Cristianismo e } \\
\text { Educação, Educação da Inteligência, Educação da } \\
\text { Vontade, Educação Moral e Religiosa, Educação Estética, } \\
\text { Educação Física) e Problemas Filosóficos da Educação. }\end{array}$ \\
\hline
\end{tabular}


A2 - Catálogos de Graduação de 1975, 1976 e 1977

\begin{tabular}{|c|c|}
\hline EMENTAS & PROGRAMAS ANALÍTICOS \\
\hline $\begin{array}{l}\text { EDU } 145 \text { - Filosofia da Educação I } \\
\text { A Filosofia: objetivo, natureza e relações com as } \\
\text { demais ciências; seu desenvolvimento histórico } \\
\text { e as principais correntes da filosofia } \\
\text { contemporânea. O problema do conhecimento. }\end{array}$ & $\begin{array}{l}\text { EDU } 145 \text { - Filosofia da Educação I } \\
\text { Introdução: o conhecimento humano. A situação da } \\
\text { Filosofia, Filosofia: conceito e objeto, Filosofia: divisão. } \\
\text { História da Filosofia: momento pré-filosófico, filosofia } \\
\text { grega, sofística e Sócrates, Platão e Aristóteles. Lógica, } \\
\text { Descoberta da razão: dualismo, racionalismo, ontologia } \\
\text { racional, idealismo. Do "cogito" cartesiano à "crítica" } \\
\text { kantiana. Maine de Biran, Fichte, Hegel e Bérgson. }\end{array}$ \\
\hline $\begin{array}{l}\text { EDU } 146 \text { - Filosofia da Educação II } \\
\text { O problema do ser. A transcendentalidade. } \\
\text { Filosofia do comportamento. Filosofia do valor. } \\
\text { O homem e a educação. A pessoa humana e seus } \\
\text { fins. Moralidade. }\end{array}$ & $\begin{array}{l}\text { EDU } 14 \text { - Filosofia da Educação II } \\
\text { A Ciência, A Metafísica, A Ética e a Arte. }\end{array}$ \\
\hline $\begin{array}{l}\text { EDU } 147 \text { - Filosofia da Educação III } \\
\text { O educando: o homem; o homem e o mundo; a } \\
\text { pessoa humana e suas operações características; } \\
\text { a dependência social da pessoa humana; } \\
\text { teleologia e pessoa humana; a educação: } \\
\text { atividade de aperfeiçoamento. Implicações da } \\
\text { educação na liberdade. }\end{array}$ & $\begin{array}{l}\text { EDU } 147 \text { - Filosofia da Educação III } \\
\text { Fundamentos Filosóficos da Educação (Filosofia e } \\
\text { Educação, Educação e finalidade, o homem, ser educável). } \\
\text { Principais correntes filosóficas sobre a Educação } \\
\text { (Naturalismo e Educação e correntes da filosofia moderna } \\
\text { e Educação). Totalitarismo e Educação, Democracias e } \\
\text { Educação. }\end{array}$ \\
\hline $\begin{array}{l}\text { EDU } 148 \text { - Filosofia da Educação IV } \\
\text { A aprendizagem frente à liberdade humana. o } \\
\text { homem, ser perceptível; a realidade do homem- } \\
\text { animal; o homem, ser solidário. Os agentes da } \\
\text { educação: o homem, a família e o estado. A } \\
\text { educação e as instituições religiosas. }\end{array}$ & $\begin{array}{l}\text { EDU } 148 \text { - Filosofia da Educação IV } \\
\text { Fundamentos Filosóficos da Educação (Cristianismo e } \\
\text { Educação, Educação da Inteligência, Educação da } \\
\text { Vontade, Educação Moral e Religiosa, Educação Estética, } \\
\text { Educação Física) e Problemas Filosóficos da Educação. }\end{array}$ \\
\hline
\end{tabular}


A3 - Catálogo de Graduação de 1978

\begin{tabular}{|c|c|}
\hline EMENTAS & PROGRAMAS ANALÍTICOS \\
\hline $\begin{array}{l}\text { EDU } 141 \text { - Filosofia } \\
\text { A Filosofia: objetivo, natureza e relações com as } \\
\text { demais ciências; seu desenvolvimento histórico } \\
\text { e as principais correntes da filosofia } \\
\text { contemporânea. O problema do conhecimento. }\end{array}$ & $\begin{array}{l}\text { EDU 141: Filosofia } \\
\text { Introdução: o conhecimento humano. A situação da } \\
\text { Filosofia, Filosofia: conceito e objeto, Filosofia: divisão. } \\
\text { História da Filosofia: momento pré-filosófico, filosofia } \\
\text { grega, sofística e Sócrates, Platão e Aristóteles. Lógica, } \\
\text { Descoberta da razão: dualismo, racionalismo, ontologia } \\
\text { racional, idealismo. Do "cogito" cartesiano à "crítica" } \\
\text { kantiana. Maine de Biran, Fichte, Hegel e Bérgson. }\end{array}$ \\
\hline $\begin{array}{l}\text { EDU } 142 \text { - Filosofia da Educação I } \\
\text { O problema do ser. A transcendentalidade. } \\
\text { Filosofia do comportamento. Filosofia do valor. } \\
\text { O homem e a educação. A pessoa humana e seus } \\
\text { fins. Moralidade. }\end{array}$ & $\begin{array}{l}\text { EDU } 142 \text {-Filosofia da Educação I } \\
\text { A Ciência, A Metafísica, A Ética e a Arte. }\end{array}$ \\
\hline $\begin{array}{l}\text { EDU } 143 \text { - Filosofia da Educação II } \\
\text { O educando: o homem; o homem e o mundo; a } \\
\text { pessoa humana e suas operações características; } \\
\text { a dependência social da pessoa humana; } \\
\text { teleologia e pessoa humana; a educação: } \\
\text { atividade de aperfeiçoamento. Implicações da } \\
\text { educação na liberdade. }\end{array}$ & $\begin{array}{l}\text { EDU } 143 \text { - Filosofia da Educação II } \\
\text { Fundamentos Filosóficos da Educação (Filosofia e } \\
\text { Educação, Educação e finalidade, o homem, ser educável). } \\
\text { Principais correntes filosóficas sobre a Educação } \\
\text { (Naturalismo e Educação e correntes da filosofia moderna } \\
\text { e Educação). Totalitarismo e Educação, Democracias e } \\
\text { Educação. }\end{array}$ \\
\hline $\begin{array}{l}\text { EDU } 144 \text { - Filosofia da Educação IV } \\
\text { A aprendizagem frente à liberdade humana. o } \\
\text { homem, ser perceptível; a realidade do homem- } \\
\text { animal; o homem, ser solidário. Os agentes da } \\
\text { educação: o homem, a família e o estado. A } \\
\text { educação e as instituições religiosas. }\end{array}$ & $\begin{array}{l}\text { EDU } 144 \text { - Filosofia da Educação IV Fundamentos } \\
\text { Filosóficos da Educação (Cristianismo e Educação, } \\
\text { Educação da Inteligência, Educação da Vontade, } \\
\text { Educação Moral e Religiosa, Educação Estética, Educação } \\
\text { Física) e Problemas Filosóficos da Educação. }\end{array}$ \\
\hline
\end{tabular}


A4 - Catálogo de Graduação de 1980, 1981, 1982, 1983 e 1984

\begin{tabular}{|c|c|}
\hline EMENTAS & PROGRAMAS ANALÍTICOS \\
\hline $\begin{array}{l}\text { EDU } 141 \text { - Filosofia } \\
\text { Filosofia: Visão histórica e conceituação. O } \\
\text { papel da Filosofia. O conhecimento humano. A } \\
\text { lógica. A ciência e a linguagem científica. } \\
\text { Correntes atuais da Filosofia. }\end{array}$ & $\begin{array}{l}\text { EDU } 141 \text { - Filosofia } \\
\text { Introdução à Filosofia, A Lógica, A Ciência e Correntes } \\
\text { atuais da Filosofia (A Fenomenologia, a Dialética, o } \\
\text { Estruturalismo e o Positivismo Lógico). }\end{array}$ \\
\hline $\begin{array}{l}\text { EDU } 142 \text { - Filosofia da Educação I } \\
\text { Filosofia da Educação. O homem e a educação. } \\
\text { Tendências e perspectivas da educação. }\end{array}$ & $\begin{array}{l}\text { EDU } 142 \text { - Filosofia da Educação I } \\
\text { Introdução (Filosofia e Educação, Ideologia e Educação, } \\
\text { Axiologia e Educação, o caráter interdisciplinar da } \\
\text { Filosofia da Educação), Instrumentalização teórica para } \\
\text { filosofar o homem (a estrutura do humano, homem: } \\
\text { consciência que se relaciona e personalismo e } \\
\text { mecanicismo), tendências e perspectivas da educação } \\
\text { (educação e essencialismo e educação e existencialismo) e } \\
\text { a educação permanente. }\end{array}$ \\
\hline $\begin{array}{l}\text { EDU } 143 \text { - Filosofia da Educação II } \\
\text { O homem e a educação. Filosofia e práxis } \\
\text { educativa. Educação e mudança social. }\end{array}$ & $\begin{array}{l}\text { EDU } 143 \text { - Filosofia da Educação II } \\
\text { Filosofar e Educação (Reflexão e Educação: condições de } \\
\text { uma reflexão crítica; o homem: sujeito-objeto da } \\
\text { educação; o homem no e, ou, além do processo } \\
\text { educacional; o homem econômico, político, social e } \\
\text { cultural); A Filosofia e a práxis educativa (a noção de } \\
\text { práxis, educação e práxis, educação e utopia e educação e } \\
\text { esperança) e o papel da educação na mudança social } \\
\text { (teoria e consciência da mudança, Pedagogia e mudança } \\
\text { social e Educação Prospectiva). }\end{array}$ \\
\hline $\begin{array}{l}\text { EDU } 144 \text { - Filosofia da Educação III } \\
\text { As críticas atuais à educação. Perspectivas } \\
\text { filosóficas e antropológicas da Sociedade } \\
\text { Industrial. Análise crítica das obras atuais sobre } \\
\text { educação. }\end{array}$ & $\begin{array}{l}\text { EDU } 144 \text { - Filosofia da Educação III } \\
\text { Instrumentalização teórica para reflexão sobre as posições } \\
\text { críticas atuais sobre a educação (Reflexão crítica da ação } \\
\text { pedagógica, Educação e crise: significado pedagógico; } \\
\text { Uma reflexão sobre a educação sulamericana; Da Filosofia } \\
\text { educacional de nosso tempo). Perspectivas filosóficas e } \\
\text { antropológicas da sociedade industrial (o homem na } \\
\text { sociedade industrial; o pensamento na sociedade } \\
\text { industrial; a Filosofia da Educação na sociedade } \\
\text { industrial); Análise crítica dos pensamentos atuais sobre a } \\
\text { educação (Ivan Illich, Neil Postmam e Charles } \\
\text { Weingartner, Evewret Reimer, Michel Foucault, Marshall } \\
\text { MacLuhan, Michel Lobrot, Edgard Faure, Carl Rogers e } \\
\text { outros). }\end{array}$ \\
\hline
\end{tabular}


A5 - Catálogo de Graduação de 1988/1989

\begin{tabular}{|c|c|}
\hline EMENTAS & PROGRAMAS ANALÍTICOS \\
\hline $\begin{array}{l}\text { EDU } 123 \text { - Filosofia } \\
\text { Filosofia: Visão histórica e conceituação. O } \\
\text { papel da Filosofia. O conhecimento humano. A } \\
\text { lógica. A ciência e a linguagem científica. } \\
\text { Correntes atuais da Filosofia. }\end{array}$ & $\begin{array}{l}\text { EDU } 123 \text { - Filosofia } \\
\text { Introdução à Filosofia, A Lógica, A Ciência e Correntes } \\
\text { atuais da Filosofia (A Fenomenologia, a Dialética, o } \\
\text { Estruturalismo e o Positivismo Lógico). }\end{array}$ \\
\hline $\begin{array}{l}\text { EDU } 124 \text { - Filosofia da Educação I } \\
\text { Filosofia da Educação. O homem e a educação. } \\
\text { Tendências e perspectivas da educação. }\end{array}$ & $\begin{array}{l}\text { EDU } 124 \text { - Filosofia da Educação I } \\
\text { Introdução (Filosofia e Educação, Ideologia e Educação, } \\
\text { Axiologia e Educação, o caráter interdisciplinar da } \\
\text { Filosofia da Educação), Instrumentalização teórica para } \\
\text { filosofar o homem (a estrutura do humano, homem: } \\
\text { consciência que se relaciona e personalismo e } \\
\text { mecanicismo), tendências e perspectivas da educação } \\
\text { (educação e essencialismo e educação e existencialismo) e } \\
\text { a educação permanente. }\end{array}$ \\
\hline $\begin{array}{l}\text { EDU } 125 \text { - Filosofia da Educação II } \\
\text { O homem e a educação. Filosofia e práxis } \\
\text { educativa. Educação e mudança social. }\end{array}$ & $\begin{array}{l}\text { EDU } 125 \text { - Filosofia da Educação II } \\
\text { Filosofar e Educação (Reflexão e Educação: condições de } \\
\text { uma reflexão crítica; o homem: sujeito-objeto da } \\
\text { educação; o homem no e/ou além do processo } \\
\text { educacional; o homem econômico, político, social e } \\
\text { cultural); A Filosofia e a práxis educativa (a noção de } \\
\text { práxis, educação e práxis, educação e utopia e educação e } \\
\text { esperança) e o papel da educação na mudança social } \\
\text { (teoria e consciência da mudança, Pedagogia e mudança } \\
\text { social e Educação Prospectiva). }\end{array}$ \\
\hline $\begin{array}{l}\text { EDU } 126 \text { - Filosofia da Educação III } \\
\text { As críticas atuais à educação. Perspectivas } \\
\text { filosóficas e antropológicas da Sociedade } \\
\text { Industrial. Análise crítica das obras atuais sobre } \\
\text { educação. }\end{array}$ & $\begin{array}{l}\text { EDU } 126 \text { - Filosofia da Educação III Instrumentalização } \\
\text { teórica para reflexão sobre as posições críticas atuais sobre } \\
\text { a educação (Reflexão crítica da ação pedagógica, } \\
\text { Educação e crise: significado pedagógico; Uma reflexão } \\
\text { sobre a educação sulamericana; Da Filosofia educacional } \\
\text { de nosso tempo). Perspectivas filosóficas e antropológicas } \\
\text { da sociedade industrial (o homem na sociedade industrial; } \\
\text { o pensamento na sociedade industrial; a Filosofia da } \\
\text { Educação na sociedade industrial); Análise crítica dos } \\
\text { pensamentos atuais sobre a educação (Ivan Illich, Neil } \\
\text { Postmam e Charles Weingartner, Evewret Reimer, Michel } \\
\text { Foucault, Marshall MacLuhan, Michel Lobrot, Edgard } \\
\text { Faure, Carl Rogers e outros). }\end{array}$ \\
\hline
\end{tabular}


A6 - Catálogo de Graduação de 1990/91, 1992/1993, 1994/1995 e 1996/1997

\begin{tabular}{|c|c|}
\hline EMENTAS & PROGRAMAS ANALÍTICOS \\
\hline $\begin{array}{l}\text { EDU } 123 \text { - Filosofia } \\
\text { A produção do homem. A produção, evolução e } \\
\text { aquisição do conhecimento. O problema } \\
\text { filosófico. A lógica. Filosofia e universidade. }\end{array}$ & $\begin{array}{l}\text { EDU } 123 \text { - Filosofia } \\
\text { A produção do homem (O trabalho como atividade do } \\
\text { homem; trabalho e alienação; cultura, linguagem e } \\
\text { humanização e a emergência da consciência humana). A } \\
\text { produção, evolução e aquisição do conhecimento (O } \\
\text { processo de conhecer; os tipos de conhecimento e o ato de } \\
\text { estudar). O problema filosófico (A especificidade da } \\
\text { filosofia; a filosofia e a ciência e os rumos da filosofia). A } \\
\text { lógica (A lógica formal e seu objetivo e a lógica dialética e } \\
\text { seus princípios). Filosofia e Universidade (O lugar da } \\
\text { filosofia na universidade e universidade: sua razão de ser). }\end{array}$ \\
\hline $\begin{array}{l}\text { EDU } 124 \text { - Filosofia da Educação I } \\
\text { Presença da Filosofia na educação. As grandes } \\
\text { correntes filosóficas e a educação. Educação e } \\
\text { contexto. }\end{array}$ & $\begin{array}{l}\text { EDU } 124 \text { - Filosofia da Educação I } \\
\text { A presença da Filosofia na educação (A educação em } \\
\text { demanda da Filosofia; A Filosofia da Educação como } \\
\text { questionamento radical do processo educativo e a } \\
\text { Filosofia na formação do educador). As grandes correntes } \\
\text { filosóficas e a educação (A filosofia da essência e a } \\
\text { educação; a filosofia da existência e a educação e } \\
\text { impasses das correntes essencialista e existencialista e a } \\
\text { perspectiva dialética). Educação e contexto (educação e } \\
\text { política; educação e valores e as ideologias da educação). }\end{array}$ \\
\hline $\begin{array}{l}\text { EDU } 125 \text { - Filosofia da Educação II } \\
\text { Visão sistematizada das diferentes concepções } \\
\text { de filosofia da educação e sua vigência na } \\
\text { educação brasileira. O predomínio da ideologia } \\
\text { católica ou a concepção humanista tradicional } \\
\text { em filosofia da educação: } 1500 \text { a 1889. A } \\
\text { consolidação da ideologia liberal ou a concepção } \\
\text { humanista moderna em filosofia da educação? } \\
1889 \text { a } 1964 \text { A supremacia da ideologia } \\
\text { tecnocrática ou a concepção analítica em } \\
\text { filosofia da educação: 1964. O espaço da } \\
\text { contradição e a força transformadora da } \\
\text { educação ou a concepção dialética em filosofia } \\
\text { da educação. }\end{array}$ & $\begin{array}{l}\text { EDU 125 - Filosofia da Educação II } \\
\text { Visão sistematizada das diferentes concepções de } \\
\text { Filosofia da Educação e sua vigência na educação } \\
\text { brasileira (As concepções fundamentais de filosofia da } \\
\text { educação; cronologia da vigência predominante de cada } \\
\text { concepção; a vinculação entre política educativa e } \\
\text { privilegiamento de concepção mais adequada à mesma). O } \\
\text { predomínio da ideologia católica ou a concepção } \\
\text { humanista tradicional em Filosofia da Educação: 1500 a } \\
\text { 1889. (Bases Greco-tomistas da concepção tradicional; } \\
\text { concepção estática e hierárquica de história e o método } \\
\text { pedagógico tradicional: seu caráter revolucionário na } \\
\text { consolidação do liberalismo e as bases científicas do } \\
\text { método: Hebart). A consolidação da ideologia liberal ou a } \\
\text { concepção humanista moderna em Filosofia da Educação: } \\
\text { 1889 a 1964 (Bases filosóficas existencialistas da } \\
\text { concepção humanista; a pedagogia renovada progressista; } \\
\text { a pedagogia renovada não-diretiva e as decorrências desta } \\
\text { concepção para a educação e a história). A supremacia da } \\
\text { ideologia tecnocrática ou a concepção analítica em } \\
\text { Filosofia da Educação: 1964 (As bases filosóficas da visão } \\
\text { analítica; a pedagogia tecnicista e decorrências para a } \\
\text { história e a educação). O espaço de contradição e a força } \\
\text { transformadora da educação ou a concepção dialética em } \\
\text { Filosofia da Educação (Bases filosóficas da concepção } \\
\text { dialética; para além da pedagogia da essência e da } \\
\text { existência; para além dos métodos novos e tradicionais; } \\
\text { para além da relação autoritária ou democrática em sala de } \\
\text { aula e decorrências desta concepção para a história e a } \\
\text { educação). }\end{array}$ \\
\hline
\end{tabular}

Continua 


\section{Conclusão}

\begin{tabular}{|c|c|}
\hline EMENTAS & PROGRAMAS ANALÍTICOS \\
\hline $\begin{array}{l}\text { EDU } 126 \text { - Filosofia da Educação III } \\
\text { Educação e ideologia. Dimensão axiótica da } \\
\text { educação na concepção tradicional, nova e } \\
\text { progressista. O trabalho como processo de } \\
\text { alienação e como princípio educativo O } \\
\text { processo de hominização ou o homem como ser } \\
\text { histórico: sujeito/objeto e intérprete da cultura. } \\
\text { Filosofia da Educação na perspectiva histórica: } \\
\text { valores comprometidos com a transformação da } \\
\text { sociedade brasileira. }\end{array}$ & $\begin{array}{l}\text { EDU 126 - Filosofia da Educação III } \\
\text { Educação e ideologia (o conceito de ideologia; ideologia: } \\
\text { categoria explicativa do conhecimento humano; educação } \\
\text { e ideologia; o significado ideológico do processo } \\
\text { educativo e a escola: ideologia nos textos didáticos). } \\
\text { Dimensão axiológica da educação na concepção } \\
\text { tradicional, nova e progressista (educação e teoria dos } \\
\text { valores; o caráter histórico e social do valor e a dimensão } \\
\text { social da liberdade; a educação tradicional e sua } \\
\text { concepção de aluno, professor, escola, mundo, contexto } \\
\text { social; a educação nova e sua concepção de aluno, } \\
\text { professor, escola, mundo, contexto social; a educação } \\
\text { progressista e suas bases axiológicas em relação ao aluno, } \\
\text { professor, escola, mundo, contexto social). O trabalho } \\
\text { como processo de alienação e como princípio educativo } \\
\text { (Atividade e práxis: o significado do trabalho humano; } \\
\text { visão histórica do trabalho; alienação e divisão social do } \\
\text { trabalho; escola e trabalho no estado capitalista e educação } \\
\text { pelo trabalho x educação para o trabalho). O processo de } \\
\text { hominização ou o homem como ser histórico: } \\
\text { sujeito/objeto e intérprete da cultura (cultura como } \\
\text { resultado da práxis; diferença entre condição humana e } \\
\text { natureza humana; cultura e humanização; as diferentes } \\
\text { concepções e utilização da cultura e a escola e a } \\
\text { reinterpretação cultural). Filosofia da Educação na } \\
\text { perspectiva histórica: valores comprometidos com a } \\
\text { transformação da sociedade brasileira (a escola e a questão } \\
\text { dos conteuudos a sem ensinados; a escola e a questão do } \\
\text { método; a escola e a questão da formação disciplinar e a } \\
\text { escola e a participação política: a real formação para a } \\
\text { cidadania). }\end{array}$ \\
\hline
\end{tabular}


A7 - Catálogo de Graduação de 2000, 2002, 2003, 2004, 2005, 2006 e 2007

\begin{tabular}{|c|c|}
\hline EMENTAS & PROGRAMAS ANALÍTICOS \\
\hline $\begin{array}{l}\text { EDU } 224 \text { Filosofia da Educação I } \\
\text { Filosofia e Filosofia da Educação. Passagem do } \\
\text { mito ao logos e antiguidade clássica. Razão e fé: } \\
\text { humanismo, racionalismo e empirismo. }\end{array}$ & $\begin{array}{l}\text { EDU } 224 \text { Filosofia da Educação I } \\
\text { Filosofia e Filosofia da Educação (Cultura e natureza e } \\
\text { formação e dever-ser). Passagem do mito ao logos e } \\
\text { antiguidade clássica (Superação do senso comum; da } \\
\text { explicação da natureza à centralidade antropológica e } \\
\text { Política: Cidadania e educação e apogeu grego e } \\
\text { helenismo) Humanismo, racionalismo e empirismo (razão } \\
\text { e fé; Patrística e neo-platonismo; universidade, escolástica } \\
\text { e aristotelismo e Humanismo renascentista e neo- } \\
\text { pitagorismo). }\end{array}$ \\
\hline $\begin{array}{l}\text { EDU } 225 \text { Filosofia da Educação II } \\
\text { Revolução científica e modernidade. Política e } \\
\text { educação no século XVIII. Referências da obra } \\
\text { de Marx. Referências e embates do século XX. }\end{array}$ & $\begin{array}{l}\text { EDU } 225 \text { Filosofia da Educação II } \\
\text { Revolução científica e modernidade (Do advento do } \\
\text { sujeito; da matematização do espaço e Descartes e } \\
\text { Galileu). Política e educação no século XVIII } \\
\text { (Liberalismo e representação e Iluminismo e democracia } \\
\text { direta); Referência da obra de Marx (Idealismo alemão, } \\
\text { socialismo utópico e economia clássica); Referências e } \\
\text { embates do século XX (Marxismo, Positivismo e } \\
\text { Fenomenologia). }\end{array}$ \\
\hline $\begin{array}{l}\text { EDU } 226 \text { Filosofia da Educação III } \\
\text { Diferentes perspectivas filosóficas da educação } \\
\text { e sua vigência no Brasil. Enfoques e abordagens } \\
\text { atuais em educação. }\end{array}$ & $\begin{array}{l}\text { EDU } 226 \text { Filosofia da Educação III } \\
\text { Diferentes perspectivas filosóficas da educação e sua } \\
\text { vigência no Brasil (concepções humanistas tradicional e } \\
\text { moderna, concepção tecnicista ou analítica e concepção } \\
\text { dialética e transformadora). Enfoques e abordagens atuais } \\
\text { em educação (Trabalho e educação; educação como } \\
\text { prática social e educação e cidadania). }\end{array}$ \\
\hline
\end{tabular}


A8 - Catálogo de Graduação de 2008 e 2009

\begin{tabular}{|c|c|}
\hline EMENTAS & PROGRAMAS ANALÍTICOS \\
\hline $\begin{array}{l}\text { EDU } 224 \text { - Filosofia da Educação I } \\
\text { Filosofia e Educação. Pensamento educacional } \\
\text { grego; patrística e escolástica. Empirismo, } \\
\text { racionalismo, cristianismo e idealismo e suas } \\
\text { relações com a educação. }\end{array}$ & $\begin{array}{l}\text { EDU } 224 \text { - Filosofia da Educação } \\
\text { Filosofia e Filosofia da Educação: sentimento da educação } \\
\text { na cultura ocidental, Atitude filosófica e Identidade da } \\
\text { Filosofia da Educação. Pensamento educacional grego, } \\
\text { patristica e escolástica: Passagem do mito ao logos e } \\
\text { Antiguidade Clássica, Patristica e neo-platonismo e } \\
\text { Escolástica e aristotelismo. Empirismo, Racionalismo, } \\
\text { Cristianismo e Idealismo e suas relações com a educação: } \\
\text { Empirismo e Racionalismo na epistemologia moderna e } \\
\text { suas relações com a educação, Projeto iluminista da } \\
\text { modernidade e a educação e Idealismo e suas relações } \\
\text { com a educação. }\end{array}$ \\
\hline $\begin{array}{l}\text { EDU } 225 \text { - Filosofia da Educação II } \\
\text { Positivismo e materialismo histórico e suas } \\
\text { relações com a educação. Diferentes } \\
\text { perspectivas filosóficas da educação no Brasil. } \\
\text { Abordagem filosófica da relação entre educação, } \\
\text { cultura e valores. Formação ética e formação } \\
\text { política. }\end{array}$ & $\begin{array}{l}\text { EDU } 225 \text { - Filosofia da Educação II } \\
\text { Positivismo e Materialismo Histórico e suas relações com } \\
\text { a educação: Positivismo e relações com a educação e } \\
\text { Marxismo e relação com a educação. } \\
\text { Diferentes perspectivas filosóficas da educação no Brasil: } \\
\text { Expressão histórica da Filosofia da Educação na cultura } \\
\text { ocidental e no Brasil e Educação como pratica social. } \\
\text { Formação Ética e Formação Política: A Filosofia e a } \\
\text { questão dos valores, A questão moral na educação e } \\
\text { Filosofia e Política. }\end{array}$ \\
\hline $\begin{array}{l}\text { EDU } 226 \text { - Filosofia da Educação III } \\
\text { Diferentes perspectivas filosóficas da educação } \\
\text { e sua vigência no Brasil. Enfoques e abordagens } \\
\text { atuais em educação. (EM EXTINÇÃO) }\end{array}$ & $\begin{array}{l}\text { EDU } 226 \text { - Filosofia da Educação III } \\
\text { Diferentes perspectivas filosóficas da educação e sua } \\
\text { vigência no Brasil (concepções humanistas tradicional e } \\
\text { moderna, concepção tecnicista ou analítica e concepção } \\
\text { dialética e transformadora). Enfoques e abordagens atuais } \\
\text { em educação (Trabalho e educação; educação como } \\
\text { prática social e educação e cidadania). }\end{array}$ \\
\hline
\end{tabular}




\section{ANEXO B \\ FORMAÇÃO ACADÊMICA DOS PROFESSORES DE FILOSOFIA E DE FILOSOFIA DA EDUCAÇÃO NA UFV}

01. Guy Capdeville era Bacharel em Filosofia, em 1957, pelo Seminário de Mariana em Minas Gerais, Bacharel em Direito, em 1965, pela Universidade Federal de Juiz de Fora, Licenciado em Letras, em 1969, pela Universidade de Toulouse na França, Licenciado em Filosofia, em 1970, na Faculdade de Filosofia, Ciências e Letras de São João Del Rei em Minas Gerais e Mestre pela Pontifícia Universidade Católica do Rio de Janeiro em 1976.

Foi admitido na UFV em 01/03/1962 e aposentou-se em 14/04/1991.

Fonte: Catálogo de Graduação da UFV e CAPDEVILLE, G.

02. José Henrique de Oliveira é graduado em Pedagogia pela Faculdade de Filosofia, Ciências e Letras São João Del Rei, em 1972, graduado em Filosofia pela Faculdade de Filosofia, Ciências e Letras São João Del Rei, em 1972, especialista em Tecnologia Educacional pela Universidade Federal de Viçosa, em 1977 e mestre em Planejamento Educacional pela Pontifícia Universidade Católica do Rio de Janeiro, em 1980. (http://lattes.cnpq.br).

Foi admitido na UFV em 19/03/ 1975

03. Olinda Maria Noronha é graduada em Pedagogia pela Faculdade de Filosofia, Ciências e Letras da Fundação de Ensino e Pesquisa de Itajubá-MG em 1971 e mestre em Filosofia da Educação pelo Instituto de Estudos Avançados em Educação da Fundação Getulio Vargas do Rio de Janeiro, em 1977. (http://lattes.cnpq.br)

Foi admitida na UFV em 17/07/1977 e pediu dispensa em 21/09/1987.

\section{0}

04. Lucio Kreutz é graduado em Filosofia pela Faculdade de Filosofia Imaculada Conceição de Viamão em 1966, graduado em Pedagogia pela Faculdade de Filosofia Imaculada Conceição de Viamão em 1967 e mestre em Educação pelo Instituto de Estudos Avançados em Educação da Fundação Getúlio Vargas do Rio de Janeiro em 1979 e doutor em Educação pela Pontifícia Universidade Católica de São Paulo, em 1985. (http://lattes.cnpq.br)

Foi admitido pela UFV em 29/08/1978, nesta permanecendo até a aposentadoria, em 05/06/1991.

05. Jose Fagundes é graduado em Filosofia pela Universidade Regional do Noroeste do Estado do Rio Grande do Sul em 1971, graduado em Pedagogia pela Universidade Regional do Noroeste do Estado do Rio Grande do Sul em 1973, bacharel em Teologia pela Universidade de Fribourg em 1966, licenciado em Teologia pela Universidade de Fribourg em 1968, mestre em Filosofia da Educação pelo Instituto de Estudos Avançados em Educação da Fundação Getulio Vargas em 1975 e doutor em Filosofia e Historia da Educação pela Universidade Estadual de Campinas em 1985. (http://lattes.cnpq.br)

Foi admitido pela UFV em 05/09/1979, nesta permanecendo até 19/04/1991, quando se aposentou.

O6. Adelino Massarolo é licenciado em Filosofia, em 1967, pela Faculdade de Filosofia, Ciências e Letras de Ijuí, mestre em Psicologia da Educação, em 1977, pelo Instituto Superior de Estudos Avançados em Educação da Fundação Getúlio Vargas.

(Catálogo de Graduação da UFV, 1991)

Foi admitido pela UFV em 05/09/1979 e permaneceu até 19/04/1991, quando se aposentou. 
07. Lucíola Licinio de Castro Paixão Santos é graduada em Comunicação Social, em 1969 e em Pedagogia, em 1972, pela Universidade Federal de Minas Gerais, em 1969, mestre em Educação, pela Universidade Federal de São Carlos, em 1980 e doutora em Educação pelo Departamento de Sociologia da Educação do Instituto de Educação da Universidade de Londres, em 1989. (http://lattes.cnpq.br)

Foi admitida pela UFV em 17/07/1977 e permaneceu até 30/12/1992, quando se aposentou.

08. José Carlos Costa é licenciado em Pedagogia pela Universidade de Campinas, em 1977 e mestre em Educação, pela Universidade de Campinas, em 1988.

(UFV, Catálogo de Graduação, 2008)

Foi admitido pela UFV em 02/06/1980 e permaneceu até 07/08/2009, quando se aposentou.

09. Marilene de Melo Vieira é graduada em Pedagogia pela Faculdade de Filosofia, Ciências e Letras de Ubá, em 1978, especialista em Fundamentos da Educação pela Universidade Federal de Viçosa, em 1986, mestre em Extensão Rural pela Universidade Federal de Viçosa, em 1993. (http://lattes.cnpq.br) Foi admitida pela UFV em 03/04/1992 (Portaria 430/1992).

10. Célia Regina Vendramini é graduada em Pedagogia pela Universidade Federal de Santa Catarina, em 1989, mestre em Educação pela Universidade Federal de São Carlos, em 1992. (http://lattes.cnpq.br) Foi admitida pela UFV em 28/04/1992 (Portaria 467/1992), permanecendo nesta até 31/08/1993, quando se transferiu.

11. Marly Silva de Melo é graduada em Pedagogia pela Faculdade de Filosofia, Ciências e Letras de Muriaé-MG, em 1971, mestre em Tecnologia Educacional pela Universidade Federal do Rio de Janeiro, em 1983.

(UFV, Catálogo de Graduação, 1991).

Foi admitida na UFV em 03/07/1977, permanecendo até 30/09/1993, quando se aposentou.

12. Eneida Pereira Gondim é graduada em Pedagogia pela Universidade Federal do Ceará, em 1973, especialista em Psicologia Educacional pela Pontifícia Universidade Católica de Minas Gerais, em 1990 e mestre em Máster of Education pela University of Arizona, em 1977. (http://lattes.cnpq.br)

Foi admitida pela UFV em 05/09/1978 e aposentou-se em 12/12/2001.

13. Willer Araújo Barbosa é licenciado em Filosofia pela Universidade Federal de Minas Gerais, em 1984 e doutor em Educação pela Universidade Federal de Santa Catarina, em 2005. (http://lattes.cnpq.br) Foi admitido pela UFV em 24/02/1994 (Portaria 236/94).

14. Maria das Graças Marcelo Ribeiro é graduada em Ciências Sociais pela Universidade Federal Fluminense, em 1978, mestre em Educação pela Fundação Getulio Vargas - RJ, em 1990 e doutora em Educação: Historia, Política, Sociedade pela Pontifícia Universidade Católica de São Paulo, em 2000. (http://lattes.cnpq.br)

Foi admitida pela UFV em 09/08/1993 (Portaria 988/1993).

15. Dileno Dustan Lucas de Souza é graduado em Pedagogia pela Universidade Federal do Rio de Janeiro, em 1994, mestre em Educação pela Universidade do Estado do Rio de Janeiro, em 1997 e doutor em Educação pela Universidade Federal do Rio Grande do Sul, em 2005. (http://lattes.cnpq.br) Foi admitido pela UFV em 19/01/1998 (Portaria 1216/1997). 
17. Rosimar de Fátima Oliveira é graduada (licenciatura e bacharelado) em Ciências Sociais pela Universidade Federal de Juiz de Fora, em 1997, mestre em Educação pela Universidade Federal de Minas Gerais, em 2000 e doutorado em Educação pela Universidade de São Paulo, em 2005. (http://lattes.cnpq.br) Foi admitida pela UFV em 18/06/2002 (Portaria 208/2002).

18. Denílson Santos de Azevedo é graduado em História pela Universidade Federal do Rio de Janeiro, em 1985, mestre em Educação pela Universidade Federal Fluminense, em 1993 e doutor em Educação pela Universidade de São Paulo, em 2005. (http://lattes.cnpq.br)

Foi admitido pela UFV em 06/09/1994 (Portaria 873/1994).

19. Gilberto Silva Santana é graduado em Filosofia pela Pontifícia Universidade Católica de Minas Gerais, em 1995, especialista em Psicopedagogia pela Universidad de la Habana, em 2000. (http://lattes.cnpq.br) Professor substituto em 2004-2006

20. Jussara Santos Pimenta é graduada em Pedagogia pela Universidade Federal de Viçosa, em 1995, mestre em Educação pela Pontifícia Universidade Católica do Rio de Janeiro, em 2001. (http://lattes.cnpq.br) Professora substituta em 2001.

21. Luciana Teixeira Mendes é graduada em Pedagogia pela Universidade Federal de Viçosa. Professora substituta em 2003.

22. Mara Denise Dias Rodrigues é graduada em Pedagogia pela Universidade Federal de Viçosa. Professora substituta em 2004. 


\begin{abstract}
ANEXO C
RELAÇÃO ANUAL DAS DISCIPLINAS DE FILOSOFIA

E FILOSOFIA DA EDUCAÇÃO E SEUS PROFESSORES
\end{abstract}

\begin{tabular}{|c|c|c|}
\hline Ano & Disciplina & Responsável \\
\hline \multirow{4}{*}{1972} & PED 145 - Filosofia da Educação I & \multirow{4}{*}{ Guy Capdeville } \\
\hline & PED 146 - Filosofia da Educação II & \\
\hline & PED 147 - Filosofia da Educação III & \\
\hline & PED 148 - Filosofia da Educação IV & \\
\hline \multirow{4}{*}{1973} & PED 145 - Filosofia da Educação I & \multirow{4}{*}{ Guy Capdeville } \\
\hline & PED 146 - Filosofia da Educação II & \\
\hline & PED 147 - Filosofia da Educação III & \\
\hline & PED 148 - Filosofia da Educação IV & \\
\hline \multirow{4}{*}{1974} & PED 145 - Filosofia da Educação I & \multirow{4}{*}{ Guy Capdeville } \\
\hline & PED 146 - Filosofia da Educação II & \\
\hline & PED 147 - Filosofia da Educação III & \\
\hline & PED 148 - Filosofia da Educação IV & \\
\hline \multirow{4}{*}{1975} & PED 145 - Filosofia da Educação I & \\
\hline & PED 146 - Filosofia da Educação II & \multirow{3}{*}{ José Henrique de Oliveira } \\
\hline & PED 147 - Filosofia da Educação III & \\
\hline & PED 148 - Filosofia da Educação IV & \\
\hline \multirow{4}{*}{1976} & PED 145 - Filosofia da Educação I & \multirow{4}{*}{ José Henrique de Oliveira } \\
\hline & PED 146 - Filosofia da Educação II & \\
\hline & PED 147 - Filosofia da Educação III & \\
\hline & PED 148 - Filosofia da Educação IV & \\
\hline \multirow{4}{*}{1977} & PED 145 - Filosofia da Educação I & Sem dados \\
\hline & PED 146 - Filosofia da Educação II & \multirow{3}{*}{ José Henrique de Oliveira } \\
\hline & PED 147 - Filosofia da Educação III & \\
\hline & PED 148 - Filosofia da Educação IV & \\
\hline \multirow{4}{*}{1978} & EDU 141 - Filosofia & Sem dados \\
\hline & EDU 142 - Filosofia da Educação I & Guy Capdeville \\
\hline & EDU 143 - Filosofia da Educação II & \multirow{2}{*}{ Olinda Maria Noronha } \\
\hline & EDU 144 - Filosofia da Educação III & \\
\hline \multirow{4}{*}{1979} & EDU 141 - Filosofia & Lúcio Kreutz \\
\hline & EDU 142 - Filosofia da Educação I & \multirow{3}{*}{ Olinda Maria Noronha } \\
\hline & EDU 143 - Filosofia da Educação II & \\
\hline & EDU 144 - Filosofia da Educação III & \\
\hline \multirow{4}{*}{1980} & EDU 141 - Filosofia & Lúcio Kreutz \\
\hline & EDU 142 - Filosofia da Educação I & \multirow{3}{*}{ Olinda Maria Noronha } \\
\hline & EDU 143 - Filosofia da Educação II & \\
\hline & EDU 144 - Filosofia da Educação III & \\
\hline
\end{tabular}


Continuação

\begin{tabular}{|c|c|c|}
\hline Ano & Disciplina & Responsável \\
\hline \multirow{4}{*}{1981} & EDU 141 - Filosofia & \multirow{4}{*}{ José Fagundes } \\
\hline & EDU 142 - Filosofia da Educação I & \\
\hline & EDU 143 - Filosofia da Educação II & \\
\hline & EDU 144 - Filosofia da Educação III & \\
\hline \multirow{4}{*}{1982} & EDU 141 - Filosofia & Adelino Massarolo \\
\hline & EDU 142 - Filosofia da Educação I & Lucíola L. de C. P Santos \\
\hline & EDU 143 - Filosofia da Educação II & José Fagundes \\
\hline & EDU 144 - Filosofia da Educação III & Adelino Massarolo \\
\hline \multirow{4}{*}{1983} & EDU 141 - Filosofia & Adelino Massarolo \\
\hline & EDU 142 - Filosofia da Educação I & José Henrique de Oliveira \\
\hline & EDU 143 - Filosofia da Educação II & Lucíola L. de C. P. Santos \\
\hline & EDU 144 - Filosofia da Educação III & Adelino Massarolo \\
\hline \multirow{4}{*}{1984} & EDU 141 - Filosofia & Adelino Massarolo \\
\hline & EDU 142 - Filosofia da Educação I & José Henrique de Oliveira \\
\hline & EDU 143 - Filosofia da Educação II & Sem dados \\
\hline & EDU 144 - Filosofia da Educação III & Adelino Massarolo \\
\hline \multirow{4}{*}{1985} & EDU 141 - Filosofia & Lúcio Kreutz \\
\hline & EDU 142 - Filosofia da Educação I & José Fagundes \\
\hline & EDU 143 - Filosofia da Educação II & \multirow{2}{*}{ Olinda Maria Noronha } \\
\hline & EDU 144 - Filosofia da Educação III & \\
\hline \multirow{4}{*}{1986} & EDU 141 - Filosofia & \multirow{2}{*}{ José Fagundes } \\
\hline & EDU 142 - Filosofia da Educação I & \\
\hline & EDU 143 - Filosofia da Educação II & Lúcio Kreutz \\
\hline & EDU 144 - Filosofia da Educação III & Olinda Maria Noronha \\
\hline \multirow{4}{*}{1987} & EDU 141 - Filosofia & \multirow{2}{*}{ José Fagundes } \\
\hline & EDU 142 - Filosofia da Educação I & \\
\hline & EDU 143 - Filosofia da Educação II & \multirow{2}{*}{ Lúcio Kreutz } \\
\hline & EDU 144 - Filosofia da Educação III & \\
\hline \multirow{4}{*}{1988} & EDU 123 - Filosofia & \multirow{2}{*}{ José Fagundes } \\
\hline & EDU 124 - Filosofia da Educação I & \\
\hline & EDU 125 - Filosofia da Educação II & \multirow{2}{*}{ Lúcio Kreutz } \\
\hline & EDU 126 - Filosofia da Educação III & \\
\hline \multirow{4}{*}{1989} & EDU 123 - Filosofia & \multirow{2}{*}{ José Fagundes } \\
\hline & EDU 124 - Filosofia da Educação I & \\
\hline & EDU 125 - Filosofia da Educação II & \multirow{2}{*}{ Lúcio Kreutz } \\
\hline & EDU 126 - Filosofia da Educação III & \\
\hline \multirow{4}{*}{1990} & EDU 123 - Filosofia & \multirow{2}{*}{ José Fagundes } \\
\hline & EDU 124 - Filosofia da Educação & \\
\hline & EDU 125 - Filosofia da Educação II & \multirow{2}{*}{ Lúcio Kreutz } \\
\hline & EDU 126 - Filosofia da Educação III & \\
\hline \multirow{4}{*}{1991} & EDU 123 - Filosofia & José Henrique de Oliveira \\
\hline & EDU 124 - Filosofia da Educação I & José Carlos Costa \\
\hline & EDU 125 - Filosofia da Educação II & \multirow{2}{*}{ Sem dados } \\
\hline & EDU 126 - Filosofia da Educação III & \\
\hline
\end{tabular}


Continuação

\begin{tabular}{|c|c|c|}
\hline Ano & Disciplina & Responsável \\
\hline \multirow{4}{*}{1992} & EDU 123 - Filosofia & \multirow{3}{*}{ Marilene de M. Vieira } \\
\hline & EDU 124 - Filosofia da Educação I & \\
\hline & EDU 125 - Filosofia da Educação & \\
\hline & EDU 126 - Filosofia da Educação III & Célia M. Vendramini \\
\hline \multirow{4}{*}{1993} & EDU 123 - Filosofia & $\begin{array}{l}\text { Marly Silva de Melo } \\
\text { Eneida Gondim }\end{array}$ \\
\hline & EDU 124 - Filosofia da Educação I & Marilene de M. Vieira \\
\hline & EDU 125 - Filosofia da Educação II & Marly Silva de Melo \\
\hline & EDU 126 - Filosofia da Educação II & Willer Araújo Barbosa \\
\hline \multirow{4}{*}{1994} & EDU 123 - Filosofia & \multirow{2}{*}{ Marilene de M. Vieira } \\
\hline & EDU 124 - Filosofia da Educação I & \\
\hline & EDU 125 - Filosofia da Educação II & Maria das G. M. Ribeiro \\
\hline & EDU 126 - Filosofia da Educação III & Willer Araújo Barbosa \\
\hline \multirow{4}{*}{1995} & EDU 123 - Filosofia & \multirow{2}{*}{ Marilene de M. Vieira } \\
\hline & EDU 124 - Filosofia da Educação I & \\
\hline & EDU 125 - Filosofia da Educação II & Maria das G M. Ribeiro \\
\hline & EDU 126 - Filosofia da Educação III & Willer Araújo Barbosa \\
\hline \multirow{4}{*}{1996} & EDU 123 - Filosofia & \multirow{2}{*}{ Marilene de M. Vieira } \\
\hline & EDU 124 - Filosofia da Educação I & \\
\hline & EDU 125 - Filosofia da Educação II & $\begin{array}{l}\text { Willer Araújo Barbosa } \\
\text { Denílson S. Azevedo }\end{array}$ \\
\hline & EDU 126 - Filosofia da Educação III & Willer Araújo Barbosa \\
\hline \multirow{4}{*}{1997} & EDU 123 - Filosofia & \multirow{2}{*}{ Marilene de M. Vieira } \\
\hline & EDU 124 - Filosofia da Educação I & \\
\hline & EDU 125 - Filosofia da Educação II & \\
\hline & EDU 126 - Filosofia da Educação III & Willer Araujo Barbosa \\
\hline \multirow{4}{*}{1998} & EDU 123 - Filosofia & \multirow{2}{*}{ Marilene de M. Vieira } \\
\hline & EDU 124 - Filosofia da Educação I & \\
\hline & EDU 125 - Filosofia da Educação II & Dileno D. L. de Souza \\
\hline & EDU 126 - Filosofia da Educação III & Willer Araújo Barbosa \\
\hline \multirow{4}{*}{1999} & EDU 123 - Filosofia & \multirow{2}{*}{ Marilene de M. Vieira } \\
\hline & EDU 124 - Filosofia da Educação I & \\
\hline & EDU 125 - Filosofia da Educação II & \\
\hline & EDU 126 - Filosofia da Educação III & Willer Araujo Barbosa \\
\hline \multirow{3}{*}{2000} & EDU 224 - Filosofia da Educação I & \multirow{2}{*}{ Willer Araújo Barbosa } \\
\hline & EDU 225 - Filosofia da Educação II & \\
\hline & EDU 226 - Filosofia da Educação III & Sem dados \\
\hline \multirow{3}{*}{2001} & EDU 224 - Filosofia da Educação I & \multirow{3}{*}{ Jussara S. Pimenta } \\
\hline & EDU 225 - Filosofia da Educação II & \\
\hline & EDU 226 - Filosofia da Educação III & \\
\hline \multirow{3}{*}{2002} & EDU 224 - Filosofia da Educação I & \multirow{3}{*}{ Rosimar de F. Oliveira } \\
\hline & EDU 225 - Filosofia da Educação II & \\
\hline & EDU 226 - Filosofia da Educação III & \\
\hline
\end{tabular}


Conclusão

\begin{tabular}{|c|c|c|}
\hline Ano & Disciplina & Responsável \\
\hline \multirow{3}{*}{2003} & EDU 224 - Filosofia da Educação I & Luciana T. Mendes \\
\hline & EDU 225 - Filosofia da Educação II & Marilene de M. Vieira \\
\hline & EDU 226 - Filosofia da Educação III & Rosimar de F. Oliveira \\
\hline \multirow{3}{*}{2004} & EDU 224 - Filosofia da Educação I & \multirow{2}{*}{ Mara D. D. Rodrigues } \\
\hline & EDU 225 - Filosofia da Educação II & \\
\hline & EDU 226 - Filosofia da Educação III & Gilberto S. Santana \\
\hline \multirow{3}{*}{2005} & EDU 224 - Filosofia da Educação I & \multirow{3}{*}{ Willer Araújo Barbosa } \\
\hline & EDU 225 - Filosofia da Educação II & \\
\hline & EDU 226 - Filosofia da Educação III & \\
\hline \multirow{3}{*}{2006} & EDU 224 - Filosofia da Educação I & \multirow{3}{*}{ Willer Araújo Barbosa } \\
\hline & EDU 225 - Filosofia da Educação II & \\
\hline & EDU 226 - Filosofia da Educação III & \\
\hline \multirow{3}{*}{2007} & EDU 224 - Filosofia da Educação I & \multirow{3}{*}{ Willer Araújo Barbosa } \\
\hline & EDU 225 - Filosofia da Educação II & \\
\hline & EDU 226 - Filosofia da Educação III & \\
\hline \multirow{3}{*}{2008} & EDU 224 - Filosofia da Educação I & \multirow{3}{*}{ Willer Araújo Barbosa } \\
\hline & EDU 225 - Filosofia da Educação II & \\
\hline & EDU 226 - Filosofia da Educação III & \\
\hline
\end{tabular}




\section{ANEXO D \\ PROFESSORES DE FILOSOFIA DA EDUCAÇÃO DA UFV: INVESTIMENTOS EM PESQUISA}

\section{D1 - PROFESSOR GUY CAPDEVILLE}

\begin{tabular}{|l|l|}
\hline Área de contratação & $\begin{array}{l}\text { Concursado na Escola Superior de Ciências } \\
\text { Domésticas e nomeado pelo Reitor - Ato n. 1.959 de } \\
02 / 08 / 1967 .\end{array}$ \\
\hline Área de atuação & $\begin{array}{l}\text { Filosofia da Educação, Administração Escolar e } \\
\text { Supervisão Escolar. }\end{array}$ \\
\hline Tempo na UFV & $\begin{array}{l}\text { Foi admitido na UFV em 01/03/1962 e aposentou-se } \\
\text { em 14/04/1991. }\end{array}$ \\
\hline Titulação & Mestre em 1976. \\
\hline Linha de pesquisa & Sem especificação \\
\hline Número de projetos de pesquisa & Sem dados \\
\hline $\begin{array}{l}\text { Número de projetos de pesquisa em Filosofia da } \\
\text { Educação }\end{array}$ & Sem dados \\
\hline Número de projetos de pesquisa/UFV & Sem dados \\
\hline Livros publicados & 01 \\
\hline Capítulos de livros & Sem dados \\
\hline Artigos em periódicos & Sem dados \\
\hline Artigos em periódicos/UFV & Sem dados \\
\hline Trabalhos em congressos & Sem dados \\
\hline Trabalhos em congressos/UFV & Sem dados \\
\hline Resumos em congressos & Sem dados \\
\hline Resumos em congressos/UFV & Sem dados \\
\hline Artigos em periódicos/Filosofia da Educação & Sem dados \\
\hline Artigos em periódicos/Filosofia da Educação/UFV & Sem dados \\
\hline Trabalhos em congressos/Filosofia da Educação & Sem dados \\
\hline Trabalhos em congressos/Filosofia da Educação/UFV & Sem dados \\
\hline Resumos em congressos/Filosofia da Educação & Sem dados \\
\hline Resumos em congressos/Filosofia da Educação/UFV & Sem dados \\
\hline Fonte: Catálogo de Graduação da UFV e CAPDEVILLE, G. \\
\hline
\end{tabular}




\section{D2 - JOSÉ HENRIQUE DE OLIVEIRA}

\begin{tabular}{|l|l|}
\hline Área de contratação & $\begin{array}{l}\text { Auxiliar de ensino no Departamento de } \\
\text { Educação }\end{array}$ \\
\hline Área de atuação & Administração Escolar \\
\hline Tempo na UFV & De 15/03/1975 a \\
\hline Titulação & Mestrado em Planejamento Educacional (1980) \\
\hline Linha de pesquisa & Sem especificação \\
\hline Número de projetos de pesquisa & 0 \\
\hline Número de projetos de pesquisa em Filosofia da Educação & 0 \\
\hline Número de projetos de pesquisa/UFV & 0 \\
\hline Livros publicados & 05 \\
\hline Capítulos de livros & 0 \\
\hline Artigos em periódicos & 0 \\
\hline Artigos em periódicos/UFV & 0 \\
\hline Trabalhos em congressos & 0 \\
\hline Trabalhos em congressos/UFV & 0 \\
\hline Resumos em congressos & 0 \\
\hline Resumos em congressos/UFV & 0 \\
\hline Artigos em periódicos/Filosofia da Educação & 0 \\
\hline Artigos em periódicos/Filosofia da Educação/UFV & 0 \\
\hline Trabalhos em congressos/Filosofia da Educação & 0 \\
\hline Trabalhos em congressos/Filosofia da Educação/UFV & 0 \\
\hline Resumos em congressos & 0 \\
\hline Resumos em congressos/Filosofia da Educação/UFV & 0 \\
\hline Font & $0 / 2009$ as \\
\hline
\end{tabular}

Fonte: http://lattes.cnpq/86757448037683264 acessada em 19/10/2009 às 17:56:09 


\section{D3 - OLINDA MARIA NORONHA}

\begin{tabular}{|l|l|}
\hline Área de contratação & Sem especificação \\
\hline Área de atuação & Filosofia da Educação \\
\hline Tempo na UFV & $\begin{array}{l}\text { Foi admitida na UFV em 17/07/1977, por credenciamento } \\
\text { em 31/05/1977 e pediu dispensa em 21/09/1987. }\end{array}$ \\
\hline Titulação & $\begin{array}{l}\text { Mestre em Educação em 1977 } \\
\text { Doutorado em Filosofia e História da Educação em 1984 }\end{array}$ \\
\hline Linha de pesquisa & Sem especificação \\
\hline Número de projetos de pesquisa & 02 \\
\hline $\begin{array}{l}\text { Número de projetos de pesquisa em Filosofia da } \\
\text { Educação }\end{array}$ & 0 \\
\hline Número de projetos de pesquisa/UFV & 0 \\
\hline Livros publicados & 04 \\
\hline Capítulos de livros & 08 \\
\hline Artigos em periódicos & 10 \\
\hline Artigos em periódicos/UFV & 0 \\
\hline Trabalhos em congressos & 17 \\
\hline Trabalhos em congressos/UFV & 0 \\
\hline Resumos em congressos & 04 \\
\hline Resumos em congressos/UFV & 0 \\
\hline Artigos em periódicos/Filosofia da Educação & 0 \\
\hline Artigos em periódicos/Filosofia da Ed./UFV & 0 \\
\hline Trabalhos em congressos/Filosofia da Educação & 0 \\
\hline Trabalhos em congressos/Fil. Educação/UFV & 0 \\
\hline Resumos em congressos/Filosofia da Educação & 0 \\
\hline Resumos em congressos/Filosofica da Ed./UFV & 0 \\
\hline Fon & a \\
\hline
\end{tabular}

Fonte: http://lattes.cnpq.br/68986228736110771 no dia 19/10/2009 às 19:08:04. 


\section{D4 - LUCIO KREUTZ}

\begin{tabular}{|l|l|}
\hline Área de contratação & Sem especificação \\
\hline Área de atuação & Filosofia da Educação, Sociologia da Educação \\
\hline Tempo na UFV & $\begin{array}{l}\text { Foi admitido na UFV em 29/08/1978, em } \\
\text { credenciamento no dia 13/09/1978 nesta } \\
\text { permanecendo até a aposentadoria, em 05/06/1991 }\end{array}$ \\
\hline Titulação & $\begin{array}{l}\text { Mestre em Educação, em 1979. } \\
\text { Doutor em Educação - Filosofia da Educação, em } \\
1985 .\end{array}$ \\
\hline Linha de pesquisa & Sem especificação \\
\hline Número de projetos de pesquisa & 11 \\
\hline Número de projetos de pesquisa em Filosofia da & 0 \\
Educação & 02 \\
\hline Número de projetos de pesquisa/UFV & 11 \\
\hline Livros publicados & 34 \\
\hline Capítulos de livros & 27 \\
\hline Artigos em periódicos & 03 \\
\hline Artigos em periódicos/UFV & 35 \\
\hline Trabalhos em congressos & 0 \\
\hline Trabalhos em congressos/UFV & 72 \\
\hline Resumos em congressos & 14 \\
\hline Resumos em congressos/UFV & 0 \\
\hline Artigos em periódicos/Filosofia da Educação & 0 \\
\hline Artigos em periódicos/Filosofia da Educação/UFV & 0 \\
\hline Trabalhos em congressos/Filosofia da Educação & 0 \\
\hline Trabalhos em congressos/Filosofia da Educação/UFV & 0 \\
\hline Resumos em congressos/Filosofia da Educação & 0 \\
\hline Resumos em congressos/Filosofia da Educação/UFV & 2009 as \\
\hline Fon & 0 \\
\hline
\end{tabular}

Fonte: http://lattes.cnpq.br/3230171689798103 em 19/10/2009 às 19:24:06. 
D5 - JOSE FAGUNDES

\begin{tabular}{|c|c|}
\hline Área de contratação & Sem especificação \\
\hline Área de atuação & Filosofia da Educação e Administração Escolar \\
\hline Tempo na UFV & $\begin{array}{l}\text { Foi admitido pela UFV em 05/09/1979, em } \\
\text { credenciamento no dia } 14 / 09 / 197, \text { nesta } \\
\text { permanecendo ate } 19 / 04 / 1991 \text {, quando se aposentou. }\end{array}$ \\
\hline Titulação & $\begin{array}{l}\text { Mestre em Filosofia da Educação em 1975. Doutor } \\
\text { em Filosofia e Historia da Educação em } 1985 .\end{array}$ \\
\hline Linhas de Pesquisa & $\begin{array}{l}\text { História da Educação } \\
\text { Formação de professores } \\
\text { Filosofia }\end{array}$ \\
\hline Número de projetos de pesquisa & 0 \\
\hline $\begin{array}{l}\text { Número de projetos de pesquisa em Filosofia da } \\
\text { Educação }\end{array}$ & 0 \\
\hline Número de projetos de pesquisa/UFV & 0 \\
\hline Livros publicados & 05 \\
\hline Capítulos de livros & 01 \\
\hline Artigos em periódicos & 16 \\
\hline Artigos em periódicos/UFV & 06 \\
\hline Trabalhos em congressos & 0 \\
\hline Trabalhos em congressos/UFV & 0 \\
\hline Resumos em congressos & 0 \\
\hline Resumos em congressos/UFV & 0 \\
\hline Artigos em periódicos/Filosofia da Educação & 0 \\
\hline Artigos em periódicos/Filosofia da Ed./UFV & 0 \\
\hline Trabalhos em congressos/Filosofia da Educação & 0 \\
\hline $\begin{array}{l}\text { Trabalhos em congressos/Filosofia da } \\
\text { Educação/UFV }\end{array}$ & 0 \\
\hline Resumos em congressos/Filosofia da Educação & 0 \\
\hline Resumos em congressos/Filosofia da Educação/UFV & 0 \\
\hline
\end{tabular}

Fonte: http:lattes.cnpq.br/3034127442358440 em 19/10/2009, às 20:01:09 
D6 - ADELINO MASSAROLO

\begin{tabular}{|l|l|}
\hline Área de contratação & Sem especificação \\
\hline Área de atuação & Psicologia da Educação e Filosofia da Educação \\
\hline Tempo na UFV & $\begin{array}{l}\text { Foi admitido pela UFV em 05/09/1979 e permaneceu } \\
\text { até 19/04/1991, quando se aposentou. }\end{array}$ \\
\hline Titulação & Mestre em Psicologia da Educação, em 1977. \\
\hline Linhas de Pesquisa & Sem dados \\
\hline Número de projetos de pesquisa & Sem dados \\
\hline $\begin{array}{l}\text { Número de projetos de pesquisa em Filosofia da } \\
\text { Educação }\end{array}$ & Sem dados \\
\hline Número de projetos de pesquisa/UFV & Sem dados \\
\hline Livros publicados & Sem dados \\
\hline Capítulos de livros & Sem dados \\
\hline Artigos em periódicos & Sem dados \\
\hline Artigos em periódicos/UFV & Sem dados \\
\hline Trabalhos em congressos & Sem dados \\
\hline Trabalhos em congressos/UFV & Sem dados \\
\hline Resumos em congressos & Sem dados \\
\hline Resumos em congressos/UFV & Sem dados \\
\hline Artigos em periódicos/Filosofia da Educação & Sem dados \\
\hline Artigos em periódicos/Filosofia da Educação/UFV & Sem dados \\
\hline Trabalhos em congressos/Filosofia da Educação & Sem dados \\
\hline Trabalhos em congressos/Filosofia da Educação/UFV & Sem dados \\
\hline Resumos em congressos/Filosofia da Educação & Sem dados \\
\hline Resumos em congressos/Filosofia da Educação/UFV & Sem dados \\
\hline Fonte: Catálogo de Graduação da UFV (1991). & \\
\hline
\end{tabular}




\section{D7 - LUCIOLA LICINIO DE CASTRO P. SANTOS}

\begin{tabular}{|c|c|}
\hline Área de contratação & Sem especificação \\
\hline Área de atuação & $\begin{array}{l}\text { Didática, Metodologias de português, Filosofia da } \\
\text { Educação, Sociologia da Educação }\end{array}$ \\
\hline Tempo na UFV & $\begin{array}{l}\text { Foi admitida pela UFV em 17/07/1977 e } \\
\text { permaneceu ate 30/12/1992, quando se aposentou. }\end{array}$ \\
\hline Titulação & $\begin{array}{l}\text { Mestre em Educação, em } 1980 . \\
\text { Doutora em Educação - Departamento de } \\
\text { Sociologia da Educação, em } 1989 .\end{array}$ \\
\hline Linhas de Pesquisa & $\begin{array}{l}\text { Análise sociológica dos processos educativos e das } \\
\text { instituições de ensino. }\end{array}$ \\
\hline Número de projetos de pesquisa & 08 \\
\hline $\begin{array}{l}\text { Número de projetos de pesquisa em Filosofia da } \\
\text { Educação }\end{array}$ & 0 \\
\hline Número de projetos de pesquisa/UFV & 0 \\
\hline Livros publicados & 0 \\
\hline Capítulos de livros & 49 após 1992 \\
\hline Artigos em periódicos & 36 \\
\hline Artigos em periódicos/UFV & 08 \\
\hline Trabalhos em congressos & 22 \\
\hline Trabalhos em congressos/UFV & 0 \\
\hline Resumos em congressos & 22 \\
\hline Resumos em congressos/UFV & 0 \\
\hline Artigos em periódicos/Filosofia da Educação & 0 \\
\hline Artigos em periódicos/Filosofia da Educação/UFV & 0 \\
\hline Trabalhos em congressos/Filosofia da Educação & 0 \\
\hline Trabalhos em congressos/Filosofia da Educação/UFV & 0 \\
\hline Resumos em congressos/Filosofia da Educação & 0 \\
\hline Resumos em congressos/Filosofia da Educação/UFV & 0 \\
\hline
\end{tabular}

Fonte: http://lattes.cnpq.br/3045743392904757 em 19/10/2009, às 21:07:38. 
D8 - JOSE CARLOS COSTA

\begin{tabular}{|l|l|}
\hline Área de contratação & Administração escolar \\
\hline Área de atuação & $\begin{array}{l}\text { Administração escolar, Sociologia da Educação, } \\
\text { Currículos, Filosofia da Ciência }\end{array}$ \\
\hline Tempo na UFV & $\begin{array}{l}\text { Foi admitido pela UFV em 02/06/1980 e } \\
\text { permaneceu até 07/08/2009, quando se aposentou. }\end{array}$ \\
\hline Titulação & Mestre em Educação em 1988. \\
\hline Linhas de Pesquisa & Sem dados \\
\hline Número de projetos de pesquisa & Sem dados \\
\hline $\begin{array}{l}\text { Número de projetos de pesquisa em Filosofia da } \\
\text { Educação }\end{array}$ & Sem dados \\
\hline Número de projetos de pesquisa/UFV & Sem dados \\
\hline Livros publicados & Sem dados \\
\hline Capítulos de livros & Sem dados \\
\hline Artigos em periódicos & Sem dados \\
\hline Artigos em periódicos/UFV & Sem dados \\
\hline Trabalhos em congressos & Sem dados \\
\hline Trabalhos em congressos/UFV & Sem dados \\
\hline Resumos em congressos & Sem dados \\
\hline Resumos em congressos/UFV & Sem dados \\
\hline Artigos em periódicos/Filosofia da Educação & Sem dados \\
\hline Artigos em periódicos/Filosofia da Educação/UFV & Sem dados \\
\hline Trabalhos em congressos/Filosofia da Educação & Sem dados \\
\hline Trabalhos em congressos/Filosofia da Educação/UFV & Sem dados \\
\hline Resumos em congressos/Filosofia da Educação & Sem dados \\
\hline Resumos em congressos/Filosofia da Educação/UFV & Sem dados \\
\hline Fon UFV, Catálogo de Gração, 2008. & \\
\hline
\end{tabular}

Fonte: UFV, Catálogo de Graduação, 2008. 
D9 - MARILENE DE MELO VIEIRA

\begin{tabular}{|l|l|}
\hline Área de contratação & Filosofia e História da Educação. \\
\hline Área de atuação & $\begin{array}{l}\text { Filosofia, Filosofia da Educação, Concepção } \\
\text { Filosófica da Educação e Ética. }\end{array}$ \\
\hline Tempo na UFV & $\begin{array}{l}\text { Foi admitida pela UFV em 03/04/1992 (Portaria } \\
430 / 1992) .\end{array}$ \\
\hline Titulação & $\begin{array}{l}\text { Mestre em Extensão Rural pela Universidade } \\
\text { Federal de Viçosa, em 1993 }\end{array}$ \\
\hline & $\begin{array}{l}\text { Filosofia da Educação } \\
\text { Filosofia no ensino médio } \\
\text { Educação e cidadania }\end{array}$ \\
\hline Linhas de Pesquisa & 20 \\
\hline Número de projetos de pesquisa & 08 \\
\hline Número de projetos de pesquisa em Filosofia da & 20 \\
\hline Educação & 02 \\
\hline Número de projetos de pesquisa/UFV & 03 \\
\hline Livros publicados & 03 \\
\hline Capítulos de livros & 03 \\
\hline Artigos em periódicos & 08 \\
\hline Artigos em periódicos/UFV & 08 \\
\hline Trabalhos em congressos & 30 \\
\hline Trabalhos em congressos/UFV & 30 \\
\hline Resumos em congressos & 01 \\
\hline Resumos em congressos/UFV & 01 \\
\hline Artigos em periódicos/Filosofia da Educação & 05 \\
\hline Artigos em periódicos/Filosofia da Educação/UFV & 05 \\
\hline Trabalhos em congressos/Filosofia da Educação & 19 \\
\hline Trabalhos em congressos/Filosofia da Educação/UFV & 19 \\
\hline Resumos em congressos/Filosofia da Educação & 2009 \\
\hline Resumos em congressos/Filosofia da Educação/UFV & 0814125 \\
\hline
\end{tabular}

Fonte: http://lattes.cnpq.br/74330558984960790 em 19/10/2009 às 21:41:25. 
D10 - CÉLIA REGINA VENDRAMINI

\begin{tabular}{|l|l|}
\hline Área de contratação & Fundamentos da Educação \\
\hline Área de atuação & Filosofia da Ciência \\
\hline Tempo na UFV & $\begin{array}{l}\text { Foi admitida pela UFV em 28/04/1992 (Portaria } \\
467 / 1992), \text { permanecendo nesta até 31/08/1993, } \\
\text { quando se transferiu. }\end{array}$ \\
\hline Titulação & Mestre em Educação em 1992. \\
\hline Linhas de Pesquisa & $\begin{array}{l}\text { Movimentos sociais e educação. } \\
\text { Trabalho e educação. }\end{array}$ \\
\hline Número de projetos de pesquisa & 07 \\
\hline Número de projetos de pesquisa em Filosofia da & 0 \\
Educação & 0 \\
\hline Número de projetos de pesquisa/UFV & 04 após a UFV \\
\hline Livros publicados & 10 após a UFV \\
\hline Capítulos de livros & 12 \\
\hline Artigos em periódicos & 0 \\
\hline Artigos em periódicos/UFV & 15 \\
\hline Trabalhos em congressos & 0 \\
\hline Trabalhos em congressos/UFV & 19 \\
\hline Resumos em congressos & 0 \\
\hline Resumos em congressos/UFV & 0 \\
\hline Artigos em periódicos/Filosofia da Educação & 0 \\
\hline Artigos em periódicos/Filosofia da Educação/UFV & 0 \\
\hline Trabalhos em congressos/Filosofia da Educação & 0 \\
\hline Trabalhos em congressos/Fil. Ed./UFV & 0 \\
\hline Resumos em congressos/Filosofia da Educação & 0 \\
\hline Resumos em congressos/Filosofia da Educação/UFV & 2009 as 8:06:08 \\
\hline
\end{tabular}

Fonte: http://lattes.cnpq.br/7441375272877530 em 20/10/2009 às 8:06:08 
D11 - MARLY SILVA DE MELO

\begin{tabular}{|l|l|}
\hline Área de contratação & \\
\hline Área de atuação & $\begin{array}{l}\text { Didática, Metodologia de Ciências, Educação } \\
\text { comparada e Metodologia do ensino superior. }\end{array}$ \\
\hline Tempo na UFV & $\begin{array}{l}\text { Foi admitida na UFV em 03/07/1977, } \\
\text { permanecendo até 30/09/1993, quando se } \\
\text { aposentou. }\end{array}$ \\
\hline Titulação & Mestre em Tecnologia Educacional em 1983. \\
\hline Linhas de Pesquisa & Sem dados \\
\hline Número de projetos de pesquisa & Sem dados \\
\hline $\begin{array}{l}\text { Número de projetos de pesquisa em Filosofia da } \\
\text { Educação }\end{array}$ & Sem dados \\
\hline Número de projetos de pesquisa/UFV & Sem dados \\
\hline Livros publicados & Sem dados \\
\hline Capítulos de livros & Sem dados \\
\hline Artigos em periódicos & Sem dados \\
\hline Artigos em periódicos/UFV & Sem dados \\
\hline Trabalhos em congressos & Sem dados \\
\hline Trabalhos em congressos/UFV & Sem dados \\
\hline Resumos em congressos & Sem dados \\
\hline Resumos em congressos/UFV & Sem dados \\
\hline Artigos em periódicos/Filosofia da Educação & Sem dados \\
\hline Artigos em periódicos/Filosofia da Educação/UFV & Sem dados \\
\hline Trabalhos em congressos/Filosofia da Educação & Sem dados \\
\hline Trabalhos em congressos/Filosofia da Educação/UFV & Sem dados \\
\hline Resumos em congressos/Filosofia da Educação & Sem dados \\
\hline Resumos em congressos/Filosofia da Educação/UFV & Sem dados \\
\hline Fonte: UFV Catálogo de Graduação, 1991 & \\
\hline
\end{tabular}

Fonte: UFV, Catálogo de Graduação, 1991. 
D12 - ENEIDA PEREIRA GONDIM

\begin{tabular}{|c|c|}
\hline Área de contratação & \\
\hline Área de atuação & $\begin{array}{l}\text { Didática, Metodologia de Ciências, Educação } \\
\text { comparada e Metodologia do ensino superior. }\end{array}$ \\
\hline Tempo na UFV & $\begin{array}{l}\text { Foi admitida na UFV em 03/07/1977, permanecendo } \\
\text { até 30/09/1993, quando se aposentou. }\end{array}$ \\
\hline Titulação & Mestre em Tecnologia Educacional em 1983. \\
\hline Linhas de Pesquisa & Sem dados \\
\hline Número de projetos de pesquisa & 0 \\
\hline $\begin{array}{l}\text { Número de projetos de pesquisa em Filosofia da } \\
\text { Educação }\end{array}$ & 0 \\
\hline Número de projetos de pesquisa/UFV & 0 \\
\hline Livros publicados & 0 \\
\hline Capítulos de livros & 0 \\
\hline Artigos em periódicos & 3 \\
\hline Artigos em periódicos/UFV & 3 \\
\hline Trabalhos em congressos & 1 \\
\hline Trabalhos em congressos/UFV & 1 \\
\hline Resumos em congressos & 1 \\
\hline Resumos em congressos/UFV & 1 \\
\hline Artigos em periódicos/Filosofia da Educação & 0 \\
\hline Artigos em periódicos/Filosofia da Educação/UFV & 0 \\
\hline Trabalhos em congressos/Filosofia da Educação & 0 \\
\hline Trabalhos em congressos/Filosofia da Educação/UFV & 0 \\
\hline Resumos em congressos/Filosofia da Educação & 0 \\
\hline Resumos em congressos/Filosofia da Educação/UFV & 0 \\
\hline
\end{tabular}

Fonte: http://lattes.cnp.br/6356602587862125 em 07/01/2010 às 18:58:40 
D13 - WILLER ARAUJO BARBOSA

\begin{tabular}{|l|l|}
\hline Área de contratação & História, Filosofia e Sociologia da Educação. \\
\hline Área de atuação & $\begin{array}{l}\text { Filosofia, Filosofia da Educação, Filosofia da Ciência } \\
\text { e Movimentos Sociais e Educação. }\end{array}$ \\
\hline Tempo na UFV & $\begin{array}{l}\text { Foi admitido pela UFV em 24/02/1994 (Portaria } \\
236 / 94) .\end{array}$ \\
\hline Titulação & Doutor em Educação em 2005. \\
\hline Linhas de Pesquisa & $\begin{array}{l}\text { Ecopedagogia, Educação ambiental popular, formação } \\
\text { de professoras e educação do campo; educação da } \\
\text { reforma agrária. }\end{array}$ \\
\hline Número de projetos de pesquisa & 02 \\
\hline $\begin{array}{l}\text { Número de projetos de pesquisa em Filosofia da } \\
\text { Educação }\end{array}$ & 0 \\
\hline Número de projetos de pesquisa/UFV & 02 \\
\hline Livros publicados & 01 \\
\hline Capítulos de livros & 04 \\
\hline Artigos em periódicos & 01 \\
\hline Artigos em periódicos/UFV & 01 \\
\hline Trabalhos em congressos & 15 \\
\hline Trabalhos em congressos/UFV & 15 \\
\hline Resumos em congressos & 14 \\
\hline Resumos em congressos/UFV & 14 \\
\hline Artigos em periódicos/Filosofia da Educação & 0 \\
\hline Artigos em periódicos/Filosofia da Educação/UFV & 0 \\
\hline Trabalhos em congressos/Filosofia da Educação & 0 \\
\hline $\begin{array}{l}\text { Trabalhos em congressos/Filosofia da } \\
\text { Educação/UFV }\end{array}$ & 0 \\
\hline Resumos em congressos/Filosofia da Educação & 0 \\
\hline Resumos em congressos/Filosofia da Educação/UFV & 0 \\
\hline Fong: & $0 / 2009$ as $8: 32.55$ \\
\hline
\end{tabular}

Fonte: http://lattes.cnpq.br/0532244867211658 em 20/10/2009 às 8:32:55 
D14 - MARIA DAS GRAÇAS MARCELO RIBEIRO

\begin{tabular}{|c|c|}
\hline Área de contratação & História, Filosofia e Sociologia da Educação \\
\hline Área de atuação & $\begin{array}{l}\text { Sociologia da Educação, Sociologia da Educação } \\
\text { Brasileira, Educação e Realidade e Mundialização } \\
\text { financeira e reformas educativas. }\end{array}$ \\
\hline Tempo na UFV & $\begin{array}{l}\text { Foi admitida pela UFV em 09/08/1993 (Portaria } \\
\text { 988/1993) }\end{array}$ \\
\hline Titulação & $\begin{array}{l}\text { Mestre em Educação em } 1990 . \\
\text { Doutora em Educação: Historia, Política, Sociedade } \\
\text { em } 2000 .\end{array}$ \\
\hline Linhas de Pesquisa & $\begin{array}{l}\text { Estado e políticas educacionais e Instituições } \\
\text { educacionais e idéias pedagógicas. }\end{array}$ \\
\hline Número de projetos de pesquisa & 07 \\
\hline $\begin{array}{l}\text { Número de projetos de pesquisa em Filosofia da } \\
\text { Educação }\end{array}$ & 0 \\
\hline Número de projetos de pesquisa/UFV & 07 \\
\hline Livros publicados & 01 \\
\hline Capítulos de livros & 02 \\
\hline Artigos em periódicos & 08 \\
\hline Artigos em periódicos/UFV & 08 \\
\hline Trabalhos em congressos & 20 \\
\hline Trabalhos em congressos/UFV & 20 \\
\hline Resumos em congressos & 23 \\
\hline Resumos em congressos/UFV & 23 \\
\hline Artigos em periódicos/Filosofia da Educação & 0 \\
\hline Artigos em periódicos/Filosofia da Educação/UFV & 0 \\
\hline Trabalhos em congressos/Filosofia da Educação & 0 \\
\hline Trabalhos em congressos/Filosofia da Educação/UFV & 0 \\
\hline Resumos em congressos/Filosofia da Educação & 0 \\
\hline Resumos em congressos/Filosofia da Educação/UFV & 0 \\
\hline
\end{tabular}

Fonte: http://lattes.cnpq.br/8454028649004343 em 20/10/2009 às 9:03:50 
D15 - DILENO DUSTAN LUCAS DE SOUZA

\begin{tabular}{|l|l|}
\hline Área de contratação & Administração escolar. \\
\hline Área de atuação & $\begin{array}{l}\text { Economia da educação, Estrutura e Funcionamento do } \\
\text { ensino, movimentos sociais e educação. }\end{array}$ \\
\hline Tempo na UFV & $\begin{array}{l}\text { Foi admitido pela UFV em 19/01/1998 (Portaria } \\
1216 / 1997) .\end{array}$ \\
\hline Titulação & $\begin{array}{l}\text { Mestre em Educação em 1997. } \\
\text { Doutor em Educação em 2005. }\end{array}$ \\
\hline Linhas de Pesquisa & $\begin{array}{l}\text { Trabalho, movimentos sociais e processos educativos. } \\
\text { Trabalho, movimentos sociais e educação (TRAMSE) }\end{array}$ \\
\hline Número de projetos de pesquisa & 14 \\
\hline $\begin{array}{l}\text { Número de projetos de pesquisa em Filosofia da } \\
\text { Educação }\end{array}$ & 0 \\
\hline Número de projetos de pesquisa/UFV & 14 \\
\hline Livros publicados & 01 \\
\hline Capítulos de livros & 01 \\
\hline Artigos em periódicos & 08 \\
\hline Artigos em periódicos/UFV & 08 \\
\hline Trabalhos em congressos & 27 \\
\hline Trabalhos em congressos/UFV & 27 \\
\hline Resumos em congressos & 47 \\
\hline Resumos em congressos/UFV & 47 \\
\hline Artigos em periódicos/Filosofia da Educação & 0 \\
\hline Artigos em periódicos/Filosofia da Ed./UFV & 0 \\
\hline Trabalhos em congressos/Filosofia da Educação & 0 \\
\hline $\begin{array}{l}\text { Trabalhos em congressos/Filosofia da } \\
\text { Educação/UFV }\end{array}$ & 0 \\
\hline Resumos em congressos/Filosofia da Educação & 0 \\
\hline Resumos em congressos/Filosofia da Educação/UFV & 0 \\
\hline
\end{tabular}

Fonte: http://lattes.cnpq.br/0438813085386094 em 20/10/2009 às 9:20:43 
D16 - ROSIMAR DE FÁTIMA OLIVEIRA

\begin{tabular}{|c|c|}
\hline Área de contratação & $\begin{array}{l}\text { Fundamentos da educação: Filosofia, História e } \\
\text { Sociologia. }\end{array}$ \\
\hline Área de atuação & $\begin{array}{l}\text { História da Educação, Filosofia da Educação, } \\
\text { Educação e Realidade brasileira r políticas públicas. }\end{array}$ \\
\hline Tempo na UFV & $\begin{array}{l}\text { Foi admitida pela UFV em 18/06/2002 (Portaria } \\
208 / 2002 \text { ) }\end{array}$ \\
\hline Titulação & $\begin{array}{l}\text { Mestre em Educação em } 2000 . \\
\text { Doutorado em Educação em } 2005 .\end{array}$ \\
\hline Linhas de Pesquisa & Estado, sociedade e educação pública. \\
\hline Número de projetos de pesquisa & 04 \\
\hline $\begin{array}{l}\text { Número de projetos de pesquisa em Filosofia da } \\
\text { Educação }\end{array}$ & 0 \\
\hline Número de projetos de pesquisa/UFV & 04 \\
\hline Livros publicados & 02 \\
\hline Capítulos de livros & 01 \\
\hline Artigos em periódicos & 04 \\
\hline Artigos em periódicos/UFV & 04 \\
\hline Trabalhos em congressos & 16 \\
\hline Trabalhos em congressos/UFV & 16 \\
\hline Resumos em congressos & 13 \\
\hline Resumos em congressos/UFV & 13 \\
\hline Artigos em periódicos/Filosofia da Educação & 0 \\
\hline Artigos em periódicos/Filosofia da Educação/UFV & 0 \\
\hline Trabalhos em congressos/Filosofia da Educação & 0 \\
\hline $\begin{array}{l}\text { Trabalhos em congressos/Filosofia da } \\
\text { Educação/UFV }\end{array}$ & 0 \\
\hline Resumos em congressos/Filosofia da Educação & 0 \\
\hline Resumos em congressos/Filosofia da Educação/UFV & 0 \\
\hline
\end{tabular}

Fonte: http://lattes.cnpq.br/2891290521082229 em 20/10/2009 às 10:28:26. 
D17 - DENILSON SANTOS DE AZEVEDO

\begin{tabular}{|c|c|}
\hline Área de contratação & Filosofia e História da Educação. \\
\hline Área de atuação & $\begin{array}{l}\text { História da Educação, Educação comparada, } \\
\text { Filosofia, Filosofia da Educação e Sociologia da } \\
\text { Educação. }\end{array}$ \\
\hline Tempo na UFV & $\begin{array}{l}\text { Foi admitido pela UFV em 06/09/1994 (Portaria } \\
\text { 873/1994). }\end{array}$ \\
\hline Titulação & $\begin{array}{l}\text { Mestre em Educação em } 1993 . \\
\text { Doutor em Educação em } 2005\end{array}$ \\
\hline Linhas de Pesquisa & $\begin{array}{l}\text { História da Educação. } \\
\text { Ensino de História da África. }\end{array}$ \\
\hline Número de projetos de pesquisa & 12 \\
\hline $\begin{array}{l}\text { Número de projetos de pesquisa em Filosofia da } \\
\text { Educação }\end{array}$ & 0 \\
\hline Número de projetos de pesquisa/UFV & 12 \\
\hline Livros publicados & 0 \\
\hline Capítulos de livros & 0 \\
\hline Artigos em periódicos & 02 \\
\hline Artigos em periódicos/UFV & 02 \\
\hline Trabalhos em congressos & 12 \\
\hline Trabalhos em congressos/UFV & 12 \\
\hline Resumos em congressos & 10 \\
\hline Resumos em congressos/UFV & 10 \\
\hline Artigos em periódicos/Filosofia da Educação & 0 \\
\hline Artigos em periódicos/Filosofia da Educação/UFV & 0 \\
\hline Trabalhos em congressos/Filosofia da Educação & 0 \\
\hline Trabalhos em congressos/Filosofia da Educação/UFV & 0 \\
\hline Resumos em congressos/Filosofia da Educação & 0 \\
\hline Resumos em congressos/Filosofia da Educação/UFV & 0 \\
\hline
\end{tabular}

Fonte: http://lattes.cnpq.br/6269500390446677 em 20/10/2009 às 10:45:00 
ANEXO E

\section{PUBLICAÇÕES ENVOLVENDO DOCENTES DA UFV QUE MINISTRARAM AS DISCIPLINAS FILOSOFIA E FILOSOFIA DA EDUCAÇÃO}

\begin{tabular}{|c|c|c|}
\hline DOCENTES & $\begin{array}{l}\text { TOTAL DE } \\
\text { PUBLICAÇÕES }\end{array}$ & TIPO DE PUBLICAÇÃO \\
\hline Guy Capdeville & 03 & 02 livros e 01 apostila \\
\hline José Henrique de Oliveira & 21 & $\begin{array}{l}02 \text { artigos, } 03 \text { resumos, } 01 \text { prefácio, } 02 \text { apostilas, } \\
\text { relatórios anuais da UFV, Proposta de Gestão, } \\
\text { Anteprojeto do Regimento e do Estatuto da UFV }\end{array}$ \\
\hline Olinda Maria Noronha & 03 & 03 artigos \\
\hline Lucio Kreutz & 00 & 00 \\
\hline Jose Fagundes & 04 & 03 artigos e 01 resumo \\
\hline Adelino Massarolo & 05 & 01 artigo, o2 boletins e 02 apostilas. \\
\hline $\begin{array}{l}\text { Lucíola Licinio de Castro Paixão } \\
\text { Santos }\end{array}$ & 10 & $\begin{array}{l}01 \text { capítulo de livro, } 03 \text { artigos, } 05 \text { resumos e } 01 \\
\text { apostila }\end{array}$ \\
\hline Jose Carlos Costa & 472 & $\begin{array}{l}01 \text { capítulo de livro, } 05 \text { artigos, } 02 \text { resumos e } 464 \\
\text { artigos em jornal. }\end{array}$ \\
\hline Marilene de Melo Vieira & 30 & $\begin{array}{l}01 \text { livro (org.), } 02 \text { capítulos de livro, } 04 \text { artigos, } 22 \\
\text { resumos e } 01 \text { artigo em jornal }\end{array}$ \\
\hline Célia Regina Vendramini & 00 & 00 \\
\hline \multicolumn{3}{|l|}{ Marly Silva de Melo } \\
\hline Eneida Pereira Gondim & 19 & 04 artigos, 03 resumos, 11 apostilas \\
\hline Willer Araújo Barbosa & 35 & $\begin{array}{l}02 \text { artigos, } 26 \text { resumos (pesquisa e extensão), } 01 \\
\text { folder, } 01 \text { artigo em jornal, } 01 \text { documento subsídio, } \\
02 \text { agenda popular, } 01 \text { oficina pedagógica, } 01 \\
\text { informativo APUFSC }\end{array}$ \\
\hline $\begin{array}{l}\text { Maria das Graças Marcelo } \\
\text { Ribeiro }\end{array}$ & 64 & $\begin{array}{l}01 \text { livro, } 02 \text { capítulos de livro, } 12 \text { artigos, } 49 \\
\text { resumos - exclusivamente pesquisa }\end{array}$ \\
\hline Dileno Dustan Lucas de Souza & 112 & $\begin{array}{l}14 \text { artigos (incluindo Educação e Sociedade), } 40 \\
\text { resumos de pesquisa, } 07 \text { resumos de extensão, } 46 \\
\text { cadernos de texto do ANDES e } 05 \text { jornais. }\end{array}$ \\
\hline Rosimar de Fátima Oliveira & 19 & 01 livro, 02 artigos, 15 resumos e o1 Editorial \\
\hline Denílson Santos de Azevedo & 21 & $\begin{array}{l}01 \text { capítulo de livro, } 03 \text { artigos, } 16 \text { resumos, } 01 \\
\text { poster. }\end{array}$ \\
\hline
\end{tabular}




\begin{abstract}
ANEXO F
RELAÇÃO DE DIRIGENTES ACADÊMICOS: PRO-REITORES ACADEMICO, PRESIDENTES DO CONSELHO DE GRADUAÇÃO E PRO-REITORES DE ENSINO DA UFV.
\end{abstract}

\begin{tabular}{|l|l|l|}
\hline CARGOS & OCUPANTES & GESTÃO \\
\hline Conselho de Graduação & José Aníbal Comastri & 1972 \\
\hline Conselho de Graduação & Eloy Gava & 1974 \\
\hline Pró-Reitor Acadêmico & Eloy Gava & $13 / 03 / 1978$ a 09/08/1982 \\
\hline Conselho de Graduação & José Mansur Nacif & $22 / 03 / 1978$ a09/08/1982 \\
\hline Pró-Reitor Acadêmico & Eloy Gava & $10 / 08 / 1982$ a 03/09/1984 \\
\hline Conselho de Graduação & Nelson Marciano & $10 / 08 / 1982$ a 03/09/1984 \\
\hline Pró-Reitor Acadêmico & Clibas Vieira & $04 / 09 / 1984$ a 26/09/1988 \\
\hline Conselho de Graduação & Ernesto Von Rückert & $04 / 09 / 1984$ a 26/09/1988 \\
\hline Pró-Reitor Acadêmico & Rubens Leite Vianello & $27 / 09 / 1988$ a 17/12/1991 \\
\hline Conselho de Graduação & Oderli de Aguiar & $27 / 09 / 1988$ a 11/10/1992 \\
\hline Pró-Reitor Acadêmico & Nei Fernandes Lopes & $18 / 12 / 1991$ a 12/10/1992 \\
\hline Pró-Reitor Acadêmico & Carlos Augusto de A. Fontes & $13 / 10 / 1992$ a 04/01/1995 \\
\hline Conselho de Graduação & Tancredo Almada Cruz & $13 / 10 / 1992$ a 09/11/1995 \\
\hline Pró- Reitora Acadêmica & Magdala Alencar Teixeira & $05 / 01 / 1995$ a 09/10/1996 \\
\hline Conselho de Graduação & Vicente de Paula Lélis & $10 / 11 / 1995$ a 09/10/1996 \\
\hline Pró-Reitor de Ensino & João Carlos Pereira & $10 / 10 / 1996$ a 03/03/1998 \\
\hline Pró-Reitor de Ensino & Frederico José Vieira Passos & $04 / 03 / 1998$ a 05/11/2000 \\
\hline Pró-Reitor de Ensino & José Benício Paes Chaves & $06 / 11 / 2000$ a 27/02/2002 \\
\hline Pró-Reitor de Ensino & Ismael Eleotério Pires & $28 / 02 / 2002^{\text {a } 28 / 11 / 2004}$ \\
\hline Pró-Reitor de Ensino & Luiz Aurélio Raggi & $29 / 11 / 2004$ a $11 / 11 / 2008$ \\
\hline Pró-Reitor de Ensino & Marines Guerreiro & $11 / 11 / 2008$ a \\
\hline
\end{tabular}




\section{ANEXO G \\ RELAÇÃO DOS DIRETORES DO CENTRO DE CIÊNCIAS HUMANAS, LETRAS E ARTES - CCH/UFV.}

\begin{tabular}{|l|l|}
\hline \multicolumn{1}{|c|}{ NOME } & \multicolumn{1}{c|}{ GESTÃO } \\
\hline Dílson Seabra Rocha & $13 / 10 / 1978$ a $09 / 08 / 1982$ \\
\hline Juraci Aureliano Teixeira & $10 / 08 / 1982$ a $04 / 04 / 1983$ - Pro-tempore \\
& $05 / 04 / 1983$ a $01 / 07 / 1985$ \\
\hline Gilson Faria Potsch Magalhães & $02 / 07 / 1985$ a $30 / 10 / 1989$ \\
\hline Juraci Aureliano Teixeira & $31 / 10 / 1989$ a $02 / 11 / 1993$ \\
\hline Paulo Shikazu Toma & $03 / 11 / 1993$ a $02 / 11 / 1997$ \\
\hline Adriel Rodrigues de Oliveira & $03 / 11 / 1997$ a $11 / 11 / 2001$ \\
\hline Rosa Maria Oliveira Fontes & $12 / 11 / 2001$ a $20 / 12 / 2006$ \\
\hline Walmer Faroni & $21 / 02 / 2006$ a \\
\hline
\end{tabular}

\section{ANEXO H}

RELAÇÃO DOS COORDENADORES DO CURSO DE PEDAGOGIA/UFV.

\begin{tabular}{|l|l|}
\hline \multicolumn{1}{|c|}{ NOME } & \multicolumn{1}{c|}{ GEST $\tilde{A} \mathbf{O}$} \\
\hline Francisco Simonini da Silva & 1978 \\
\hline Francisco Simonini da Silva & $10 / 12 / 1979$ a 26/05/1981 \\
\hline \multicolumn{1}{|c|}{ SEM DADOS } & $\mathbf{2 7 / 0 5 / 1 9 8 1 ~ a ~ 0 1 / 0 4 / 1 9 9 1}$ \\
\hline Rita Maria de Melo Alencar & $02 / 04 / 1991$ a 14/06/1992 \\
\hline Eneida Pereira Gondim & $15 / 06 / 1992$ a 06/05/1993 \\
\hline Maria das Graças Floresta Leal & $07 / 06 / 1993$ a $18 / 11 / 1993$ \\
\hline Eneida Pereira Gondim & $19 / 11 / 1993$ a 09/05/1994 \\
\hline Marilene de Melo Vieira & $20 / 06 / 1994$ a 27/01/1997 \\
\hline Carlos Vasconcelos Farias & $28 / 01 / 1997$ a 02/03/1999 \\
\hline Marisa Barletto & $02 / 03 / 1999$ a 02/03/2001 \\
\hline Rita de Cássia de Alcântara Braúna & $02 / 03 / 2001$ a 25/07/2002 \\
\hline Rosa Cristina Porcaro & $26 / 07 / 2002$ a 26/08/2003 \\
\hline Marilene de Melo Vieira & $26 / 08 / 2003$ a 13/05/2005 \\
\hline José Henrique de Oliveira & $13 / 05 / 2005$ a 13/05/2007 \\
& $14 / 05 / 2007$ a 26/01/2009 \\
\hline
\end{tabular}

